Тернопільський національний технічний університет імені Івана Пулюя

Тернопільська міська рада

Корпорація «Науковий парк «Інноваційноінвестиційний кластер Тернопілля» «Страхова компанія «ТАС»

Вроцлавський економічний університет Університет «Опольська Політехніка»

Університет прикладних наук в Нисі

Ельблонзький університет гуманітарних та економічних наук

Індо-Європейська освітня фундація (Республіка Польща)

Університет Дунареа де Йос м. Галац (Румунія)
Ternopil Ivan Puluj National Technical University Ternopil CityCouncil

Corporation «Scientific Park - Innovation and Investment Cluster of Ternopil Region» Insurance company «TAS»

Wroclaw University of Economics

Opole University of Technology

University of Applied Sciences in Nysa

Elblag University of Humanities and Economics

Indo-European Educational Foundation (the Republic of Poland)

University Dunarea de Jos of Galati (Romania)

\title{
МАТЕРІАЛИ
}

\author{
III Міжнародної науково-практичної конференції \\ «ФОРМУВАННЯ МЕХАНІЗМУ ЗМНЦНЕННЯ КОНКУРЕНТНИХ \\ ПОЗИЦІЙ НАЦІОНАЛЬНИХ ЕКОНОМІЧНИХ СИСТЕМ У \\ ГЛОБАЛЬНОМУ, РЕГІОНАЛЬНОМУ ТА ЛОКАЛЬНОМУ ВИМІРАХ»
}

Proceedings of the $3^{\text {nd }}$ International Scientific-Practical Conference "FORMATION OF THE MECHANISM OF NATIONAL ECONOMIC SYSTEMS

COMPETITIVE POSITIONS STRENGTHENING IN

GLOBAL, REGIONAL AND LOCAL DIMENSIONS" 


\section{УДК 330:336:338}

Матеріали III Міжнародної науково-практичної конференції «Формування механізму зміцнення конкурентних позицій національних економічних систем у глобальному, регіональному та локальному вимірах» (5 квітня 2019 р.) / Тернопільський національний технічний університет імені Івана Пулюя. - Тернопіль: ФОП Паляниця В. А., 2019. - 168 с.

\section{ПРОГРАМНИЙ КОМІТЕТ}

Голова - Рогатинський Р. М., проректор з наукової роботи ТНТУ ім. І. Пулюя, д.т.н., професор Співголова - Ціх Г. В., декан факультету економіки та менеджменту ТНТУ ім. І. Пулюя, к.е.н., доцент Співголова - Панухник О. В., завідувач кафедри економіки та фінансів ТНТУ ім. І. Пулюя, д.е.н., професор Члени:

Бицюра Л. О. - заступник міського голови з питань діяльності виконавчих органів ради (м.Тернопіль, Україна) Химич Г. П. - директор Корпорації «Науковий парк «Інноваційно-інвестиційний кластер Тернопілля»»» Зелінська Анетта - професор факультету управління, комп'ютерних наук та фінансів Вроцлавського економічного університету, Dr.Наb (м. Вроцлав, Республіка Польща) - за згодою

Клеменс Бригіда - заступник декана з навчальної роботи факультету економіки та менеджменту Університету «Опольська Політехніка», Ph.D (м. Ополє, Республіка Польща) - за згодою

Опалка Анна - керівник відділу з міжнародних зв’язків Університету прикладних наук в Нисі, $\mathrm{PhD}$ (м. Ниса, Республіка Польща) - за згодою

Вілімовська Зоф’я - директор інституту фінансів Університету прикладних наук в Нисі, Dr.Hab. (м. Ниса, Республіка Польща) - за згодою

Рокіта-Поскарт Діана - асистент кафедри регіональної політики Університету «Опольська Політехніка», Ph.D (м. Ополе, Республіка Польща) - за згодою

Середоха Ізабелла - заступник декана факультету адміністрації та соціальних наук, Ельблонзький університет гуманітарних та економічних наук (м. Ельблонг, Республіка Польща) - за згодою

Кумар Прадіп - голова Індо-Свропейської освітньої фундації, PhD (м. Варшава, Республіка Польща) - за згодою

Зека Єкатеріна Даніела - виконавчий директор Документаційного центру управління маркетингу в промисловості та сільському господарстві, Університет Дунареа де Йос м. Галац, PhD (м. Галац, Румунія) - за згодою

\section{ОРГАНІЗАЦЙНИЙ КОМІТЕТ}

Голова - Панухник О. В., завідувач кафедри економіки та фінансів ТНТУ ім. І. Пулюя, д.е.н., професор Члени:

Науково-педагогічні працівники та навчально-допоміжний персонал кафедри економіки та фінансів ТНТУ ім. І. Пулюя:

Артеменко Л. Б., Бажанова Н. В., Винник Т. М., Дячун О. Д., Константюк Н. І., Крамар І. Ю., Крупка А. Я., Кудлак В. Я., Малинич Г. М., Мариненко Н. Ю., Левицький В. О., Подвірна Т. В., Радинський С. В., Тимошик Н. С., Фещин I. М., Химич I. Г.

Науковий секретар

Маркович I. Б. - доцент кафедри економіки та фінансів ТНТУ ім. I. Пулюя, к.е.н., доцент

Рекомендовано до друку Вченою радою факультету економіки та менеджменту Тернопільського начіонального технічного університету імені Івана Пулюя, протокол № 6 від 23.04.2019 p.

Відповідальність за зміст і достовірність публікацій несуть автори.

ISBN 978-617-7331-79-6

(C) Тернопільський національний технічний університет імені Івана Пулюя, 2019 
СЕКЦІЯ 1. РОЗВИТОК СОЦІАЛЬНО-ЕКОНОМІЧНИХ СИСТЕМ МІКРО-, МЕЗО- І МАКРОРІВНЯ: КОНФЛІКТ ТРАДИЦЙНИХ МОДЕЛЕЙ ТА

Агарков Олександр

СИСТЕМА УПРАВЛІННЯ ФІНАНСОВИМИ РИЗИКАМИ ПІДПРИСМСТВА.

Бажанова Наталія

ТЕНДЕНЦІЇ ТА ПЕРСТПЕКТИВИ ПРИРОДНЬОГО

ПРИРОСТУ НАСЕЛЕННЯ В УКРАЇНІ

Винник Тетяна

СПОЖИВЧИЙ КОШИК ЯК КРИТЕРІЙ РІВНЯ ЖИТТЯ НАСЕЛЕННЯ

Гречко Алла

ФІСКАЛЬНІ СТИМУЛИ ЯК ПЕРЕДУМОВА ПІДВИЩЕННЯ

КОНКУРЕНТОСПРОМОЖНОСТІ РЕГІОНІВ.

Ілляшенко Сергій

НОВА ОРГАНІЗАЦІЙНА МОДЕЛЬ ФУНКЦІОНУВАННЯ ВИПУСКОВОЇ

КАФЕДРИ УНІВЕРСИТЕТУ: ЗДОБУТКИ І ПРОТИРІЧЧЯ.

Клемпарський Микола, Тетяна Ларіна

ЕЛІТА ЯК СУБ’ЄКТ ІНСТИТУЦІЙНОЇ ДИНАМІКИ

Козак Зоряна

ПРИНЦИПИ ФОРМУВАННЯ БЕЗПЕКИ БАНКІВСЬКОЇ ДІЯЛЬНОСТІ

Кондратюк Надія

ОЦІНКА ВІДКРИТОСТІ ЕКОНОМІКИ УКРАЇНИ.

Константюк Наталія, Черенко Ірина

ОЦІНКА ФІНАНСОВОГО СТАНУ ПІДПРИЄМСТВА ЯК НЕОБХІДНА СКЛАДОВА

ПРИЙНЯТТЯ УПРАВЛІНСЬКИХ РІШЕНЬ ДЛЯ ЕФЕКТИВНОЇ

ДІЯЛЬНОСТІ ПІДПРИЄМСТВА

Константюк Наталія

ВАЖЛИВІСТЬ ФІНАНСОВОГО ЗАБЕЗПЕЧЕННЯ ОСВІТИ ДЛЯ

ЕКОНОМІЧНОГО ТА СОЦАЛЬНОГО РОЗВИТКУ ДЕРЖАВИ

Крутько Маргарита

АКТИВІЗАЦІЯ РОЗВИТКУ АГРОПРОМИСЛОВОЇ ІНТЕГРАЦІЇ.

Малинич Ганна, Сливка Оксана

НАВИКИ ТА КОМПЕТЕНЦІЇ ПРАЦІВНИКА У ХХІ СТОЛІТТІ:

ПОГЛЯД РОБОТОДАВЦЯ

Мардус Наталія

ПРОГНОЗУВАННЯ ЗАБЕЗПЕЧЕННЯ РОЗВИТКУ ВНУТРІШНЬОГО РИНКУ ТОВАРІВ

Маркович Ірина

ПОЛІЦЕНТРИЧНИЙ РОЗВИТОК РЕГІОНІВ В КОНТЕКСТІ

ПРОЦЕСІВ ДЕЦЕНТРАЛІЗАЦІЇ

Подвірна Тетяна

ОСОБЛИВОСТІ ФІНАНСУВАННЯ ОБ'ЄДНАНИХ

ТЕРИТОРІАЛЬНИХ ГРОМАД ДЕРЖАВНИМ БЮДЖЕТОМ

СЕКЦІЯ 2. ОСОБЛИВОСТІ ІНТЕГРАЦІЇ ДЕРЖАВИ, БІЗНЕСУ, НАУКИ,

ОСВІТИ В УМОВАХ ЦИФРОВІЗАЦІЇ СУСПІЛЬСТВА

Iryna Kramar

UNIVERSITY-INDUSTRY COLLABORATION 35 
Pululu Yonda Heritier

DIGITAZATION IN DIFFERENT AREAS OF LIFE

Дячун Ольга

ЧИННИКИ, ЩО ВПЛИВАЮТЬ НА ФОРМУВАННЯ СИСТЕМИ ЗБУТУ

ПРОДУКЦІЇ ПІДПРИЕМСТВ.

Костик Свгеній

ГЛОБАЛІЗАЦЙНІ ПРОЦЕСИ В СУЧАСНИХ УМОВАХ ТРАНСФОРМАЦІЇ

СВІТОВОЇ ЕКОНОМІКИ

Левицький Віталій, Швець Ігор

ФІНАНСОВИЙ РЕЗУЛЬТАТ ДІЯЛЬНОСТІ ПІДПРИСМСТВА

ЯК ЕКОНОМІЧНА КАТЕГОРІЯ ТА ОБ’ЄКТ АНАЛІЗУ

Левицький Віталій

ГОЛОВНІ РИСИ ВКЛЮЧЕННЯ УКРАЇНИ В ГЛОБАЛІЗАЦІЙНІИ ПРОЦЕСИ

Пастух Марія, Бажанова Наталія

НАВЧАННЯ, ЩО СПОНУКАС ДО КАРДИНАЛЬНИХ ЗМІН.

Підоричена Ірина

ФОРМУВАННЯ ІННОВАЦІЙНИХ ЕКОСИСТЕМ В УМОВАХ ГЛОБАЛІЗАЦІЇ

48

Струтинська Ірина

ПЕРЕДУМОВИ ТРАНСФОРМАЦІІ ДЕРЖАВИ ТА БІЗНЕСУ В УМОВАХ

ЦИФРОВОЇ ЕКОНОМІКИ

СЕКЦІЯ З. РОЛЬ ТА ПОТЕНЦАЛ ВІТЧИЗНЯНОГО ПІДПРИЕМНИЦТВА У

РОЗВИТКУ ЕКОНОМІЧНО СТІЙКОЇ ДЕРЖАВИ

Власенко Тетяна

НАУКОВО-МЕТОДОЛОГІЧНІ ЗАСАДИ СТРАТЕГІЧНИХ ЗМІН В

ДІЯЛЬНОСТІ ПІДПРИЄМСТВА.

Власова К. М., Філюк Г.М.

ВПЛИВ БАР'ЄРІВ НА ВИБІР СПОСОБУ ВХОДЖЕННЯ

НА ЗОВНІШНІЙ РИНОК

Гладка Антоніна

ФІНАНСОВЕ ЗАБЕЗПЕЧЕННЯ ДІЯЛЬНОСТІ СУБ ЄКТІВ МАЛОГО

ТА СЕРЕДНЬОГО БІЗНЕСУ

Капшій Юрій

ОСОБЛИВОСТІ АНАЛІЗУ ЕКОНОМІЧНОГО ПОТЕНЦІАЛУ

СУБ ЄКТА ПІДПРИЄМНИЦТВА.

Кобильняк Ганна

РОЗВИТОК ПІДПРИСМНИЦТВА В АГРАРНОМУ СЕКТОРІ

ЕКОНОМІКИ УКРАЇНИ

Ковальчук Руслан-Петро

ЯКІСТЬ ТОВАРУ ЯК ФАКТОР УСПІШНОГО ФУНКЦІОНУВАННЯ

СУБ’ЄКТІВ ГОСПОДАРЮВАННЯ

Корнісцький Олександр

МОТИВАЦІЙНІ ПРИНЦИПИ РЕГІОНАЛЬНОГО

УПРАВЛІННЯ СІЛЬСЬКИХ ТЕРИТОРІЙ

Легеза Назар

ТЕОРЕТИЧНІ АСПЕКТИ РОЗВИТКУ ПІДПРИЕМСТВА

66

Радинський Сергій, Дьолог Івета

МЕХАНІЗМИ УПРАВЛІННЯ МАЙНОМ ПІДПРИСМСТВА 68 
Радинський Сергій, Михальська Марія-Роксолана

МЕХАНІЗМИ ПІДВИЩЕННЯ ЕФЕКТИВНОСТІ ЗБУТОВОЇ

ДІЯЛЬНОСТІ НА ПІДПРИЕМСТВІ

Орел Анна

ВПЛИВ РЕСУРСНОГО ЗАБЕЗПЕЧЕННЯ НА ДІЯЛЬНІСТЬ

СІЛЬСЬКОГОСПОДАРСЬКОГО ПІДПРИЄМСТВА .

Орел Володимир

ВПРОВАДЖЕННЯ КОМПЛЕКСНОЇ СИСТЕМИ

МЕНЕДЖМЕНТУ НА ПІДПРИСМСТВІ.

Панухник Олена

СИСТЕМНА ВЗАСМОДІЯ СУБ'ЄКТІВ ЕКОНОМІЧНИХ

ВІДНОСИН ЯК ОСНОВА ПОСТУПАЛЬНОГО РОЗВИТКУ

ТЕРИТОРІАЛЬНО-ГОСПОДАРСЬКИХ СИСТЕМ

Приймак Наталія

СИСТЕМА ВНУТРІШНІХ СТЕЙКХОЛДЕРІВ ЯК ОБ ЄКТ

УПРАВЛІННЯ ЗМІНАМИ

Ряснянська Альона

АНАЛІЗ СТАНУ МАЛОГО БІЗНЕСУ В ХАРКІВСЬКІЙ ОБЛАСТІ

Стасюк Володимир

ПРИБУТОК ЯК ЕКОНОМІЧНА КАТЕГОРІЯ ТА ЙОГО РОЛЬ

В СУЧАСНИХ УМОВАХ.

Химич Ірина, Балацко Богдан

ФРЕЙМІНГ ЯК МЕТОД ЗАБЕЗПЕЧЕННЯ КОНКУРЕНТОЗДАТНОСТІ БІЗНЕСУ ....

Химич Ірина, Колісник Іван

КРЕАТИВНІСТЬ ІДЕЙ НА ОСНОВІ БРЕЙНСТОРМІНГУ

Швак Ольга

СТАН ТА ДИНАМІКА РОЗВИТКУ МОЛОЧНОЇ ГАЛУЗІ УКРАЇНИ.

Ямборко Петро

ІНВЕСТИЦІЙНА ПРИВАБЛИВІСТЬ ПІДПРИСМСТВА: ТЕОРЕТИЧНІ ПІДХОДИ

СЕКЦІЯ 4. СУЧАСНИЙ РОЗВИТОК ФІНАНСОВОГО РИНКУ УКРАЇНИ:

МОЖЛИВОСТІ, ВИКЛИКИ, ЗАГРОЗИ.

Гогусь Соломія, Малинич Ганна

РОЛЬ ФІНАНСОВИХ РЕСУРСІВ ВІТЧИЗНЯНИХ ДОМОГОСПОДАРСТВ

У ЗАБЕЗПЕЧЕННІ РОЗВИТКУ ФІНАНСОВОГО РИНКУ

Дзюрдзевич Максим

РЕСУРСНИЙ ПОТЕНЦІАЛ БАНКУ

Долик Катерина, Бажанова Наталія

СУЧАСНИЙ СТАН ФІНАНСОВОГО РИНКУ УКРАЇНИ ТА ШЛЯХИ ЙОГО

ВДОСКОНАЛЕННЯ

Ізоткін Вадим, Бажанова Наталія

ФІНАНСОВА ГРАМОТНІСТЬ, ЯК ГАРАНТІЯ ОСОБИСТОЇ

ФІНАНСОВОЇ БЕЗПЕКИ

Кучеренко Світлана, Малишко Віталіна

ТЕНДЕНЦІЇ ТА ПЕРСПЕКТИВИ РОЗВИТКУ ЛІЗИНГУ В УКРАЇНІ.

Михайлевська Юлія

ІПОТЕЧНЕ КРЕДИТУВАННЯ В УКРАЇНІ: ПРОБЛЕМИ

ТА ПЕРСПЕКТИВИ РОЗВИТКУ 
Прийма Антоніна, Тимошик Наталія

ІДЕНТИФІКАЦІЯ БАНКІВСЬКИХ РИЗИКІВ В СИСТЕМІ

ФІНАНСОВОГО ПЛАНУВАННЯ.

Процків Оксана

ЕКОНОМІЧНА БЕЗПЕКА ПІДПРИСМСТВА ТА ІІЇ

ФІНАНСОВА СКЛАДОВА.

Радинський Сергій

ІНВЕСТИЦІЙНИЙ КЛІМАТ В УКРАЇНІ

Степаненко Сергій

НАУКОВО-ТЕОРЕТИЧНІ ЗАСАДИ УПРАВЛІННЯ КРЕДИТНИМИ

РИЗИКАМИ КОМЕРЦИЙНОГО БАНКУ

Тимошик Наталія

ЕЛЕМЕНТИ ФІНАНСОВОГО МЕХАНІЗМУ ЯК ЗАСІБ УПРАВЛІННЯ

СЕКЦІЯ 5. ІННОВАЦІЇ У ГЛОБАЛЬНІЙ БІРЖОВІЙ СФЕРІ ТА

БАНКІВСЬКІЙ ДІЯЛЬНОСТІ

Голич Наталія, Панухник Олена

ДЕРЖАВНА ПІДТРИМКА ТРАНСФЕРУ ІННОВАЦІЙНИХ ПРОЦЕСІВ

В МАЛОМУ БІЗНЕСІ

СЕКЦІЯ 6. СТРАХОВИЙ РИНОК УКРАЇНИ - КАТАЛІЗАТОР ЧИ СТРИМУВАЧ

ПРОГРЕСИВНИХ ЗМІН У ВІТЧИЗНЯНІЙ ЕКОНОМІЧНІЙ СИСТЕМІ?

Гой Віта

КІБЕР-СТРАХУВАННЯ ЯК НОВИЙ ПРОДУКТ НА РИНКУ СТРАХОВИХ ПОСЛУГ.

Гула Інна

ПРОБЛЕМА ОПОДАТКУВАННЯ СТРАХОВИХ КОМПАНІЙ В УКРАЇНІ

Михалочкіна Марина

УМОВИ ВПРОВАДЖЕННЯ ТА РОЗВИТКУ СИСТЕМИ РИЗИК-МЕНЕДЖМЕНТУ

В СТРАХОВИХ КОМПАНІЯХ УКРАЇНИ

Михно Наталія, Малинич Ганна

РИНОК СТРАХУВАННЯ ЖИТТЯ В УКРАЇНІ ТА ЙОГО ІНДИКАТОРИ

Ожібко Мар'яна

ПРОБЛЕМИ ТА ПЕРСПЕКТИВИ РОЗВИТКУ СТРАХОВОГО РИНКУ УКРАЇН

СЕКЦЯ 7. ЕКОНОМІЧНО ЕФЕКТИВНА ТОРГІВЛЯ: РОЗУМІННЯ СУТІ ТА

СУЧАСНІ ПІДХОДИ ДО ЇЇ ВЕДЕННЯ

Гундерук Тетяна, Малинич Ганна

ТРАНСФОРМАЦІЯ ФОРМ ТОРГІВЛІ: ВІД ВИТОКІВ ДО СУЧАСНОСТІ.

Рудюк Ірина, Бажанова Наталія

ТОРГІВЛЯ МАЙБУТНЬОГО: ПРОБЛЕМИ ТА ПЕРСПЕКТИВИ

Хвостіков Андрій

СУТНІСТЬ МІЖНАРОДНИХ ТОРГІВЕЛЬНО-ЕКОНОМІЧНИХ

ВІДНОСИН В АГРАРНОМУ СЕКТОРІ

СЕКЦІЯ 8. МАЙБУТНС КОНКУРЕНТОСПРОМОЖНОСТІ: РОЗУМНЕ

УПРАВЛІННЯ, РОЗУМНІ ТЕРИТОРІЇ, РОЗУМНИЙ БІЗНЕС

Daniel Sarpong Mensah

SMART BUSINESS PROCESS MANAGEMENT AS A TOOL FOR

ECONOMIC DEVELOPMENT

Tsikh Halyna, Marynenko Nataliia

OUTSOURCING IT JAKO SPOSÓB NA POPRAWĘ EFEKTYWNOŚCI

DZIAŁALNOŚCI GOSPODARCZEJ 


\section{Анопріснко Тетяна}

ОБ’ЄДНАНІ ТЕРИТОРАЛЬНІ ГРОМАДИ - ШЛЯХ ДЛЯ

ПОКРАЩЕННЯ ЕКОНОМІЧНОГО РОЗВИТКУ ДЕРЖАВИ

Артеменко Людмила, Ціх Галина

ПЕРСПЕКТИВИ РОЗВИТКУ РИНКУ ОРГАНІЧНОЇ ПРОДУКЦІЇ УКРАЇНИ

Боднар Діана

ДІЯЛЬНІСТЬ ПІДПРИСМСТВ В УМОВАХ КОНКУРЕНЦІї

Ігнатенко Микола, Кучеренко Микола

УДОСКОНАЛЕННЯ КОНКУРЕНТОСПРОМОЖНОСТІ

АГРАРНИХ ПІДПРИЕМСТВ

Катрусяк Христина, Бажанова Наталія

ПРОБЛЕМИ ВПРОВАДЖЕННЯ ІННОВАЦІЙНИХ ТЕХНОЛОГІЙ

ВИРОБНИЦТВА В УКРАЇНІ

Красноруцький Олексій, Зайцев Юрій

НАПРЯМКИ ВДОСКОНАЛЕННЯ ЗБУТОВОЇ ДІЯЛЬНОСТІ

АГРАРНИХ ПІДПРИЕМСТВ

Крупка Андрій, Пиріг Галина

КУЛЬТУРНО-МИСТЕЦЬКІ ІНДУСТРІЇ В УКРАЇНІ: СУЧАСНИЙ

СТАН ТА ПЕРСПЕКТИВИ РОЗВИТКУ

Лазарюк Валерій

ІННОВАЦЙНІ ЛАБОРАТОРІЇ ФАБЛАБ ЯК ІНДИКАТОР

РЕГІОНАЛЬНОГО РОЗВИТКУ КРЕАТИВНОЇ ЕКОНОМІКИ

Мармуль Лариса, Леваєва Людмила

СТРАТЕГІЧНІ НАПРЯМИ РОЗВИТКУ КОНКУРЕНТОСПРОМОЖНОСТІ

В АГРАРНИХ ПІДПРИЕМСТВАХ.

Нагорняк Галина, Малюта Людмила, Атаманов Ігор

ІНТЕЛЕКТУАЛЬНИЙ КАПІТАЛ ЯК УМОВА СТАНОВЛЕННЯ

КОНКУРЕНТНИХ ПЕРЕВАГ ВІТЧИЗНЯНИХ ПІДПРИСМСТВ

Нагорняк Ірина

ЗМІСТ ЕКОНОМІЧНОГО ІНТЕЛЕКТУАЛЬНОГО КАПІТАЛУ

ЯК ЧИННИКА ПОСИЛЕННЯ КОНКУРЕНТОСПРОМОЖНОСТІ

СУЧАСНОГО ПІДПРИЕМСТВА

Новік Яна

ІННОВАЦІЙНИЙ РОЗВИТОК ОСВІТНЬОГО ПРОСТОРУ 160

Пілічева Марина

ОБЛІК ЗЕМЕЛЬ - ОСНОВА ЕФЕКТИВНОГО УПРАВЛІННЯ

ЗЕМЕЛЬНИМИ РЕСУРСАМИ

Семчишин Свгенія, Смачило Ліля

УКРАЇНА В СИСТЕМІ СВІТОВОЇ КОНКУРЕНТОСПРОМОЖНОСТІ

Суска Анастасія, Бабич Анатолій

ЕКОЛОГО-ТЕХНІЧНА КОНКУРЕНЦІЯ ЯК ВИД

МІЖГАЛУЗЕВОЇ КОНКУРЕНЦІЇ 166 


\title{
СЕКЦІЯ 1.
}

\section{РОЗВИТОК СОЦІАЛЬНО-ЕКОНОМІЧНИХ СИСТЕМ МІКРО-, МЕЗО- I МАКРОРІВНЯ: КОНФЛІКТ ТРАДИЦІЙНИХ МОДЕЛЕЙ ТА ЕКОНОМІЧНИХ РЕАЛІЙ 21 СТОЛІТТЯ}

УДК 338

\author{
Агарков Олександр \\ студент групи ППм-51 \\ Тернопільський національний технічний університет імені Івана Пулюя \\ м. Тернопіль, Україна \\ Науковий керівник: Маркович Ірина \\ кандидат економічних наук, доцент \\ Тернопільський національний технічний університет імені Івана Пулюя \\ Тернопіль, Україна \\ Agarkov Oleksandr \\ Student of group PPm-51 \\ Ternopil Ivan Puluj National Technical University \\ Ternopil, Ukraine \\ Scientific supervisor: Markovych Iryna \\ $\mathrm{PhD}$ in Economics, Associate Professor \\ Ternopil Ivan Puluj National Technical University \\ Ternopil, Ukraine
}

\section{СИСТЕМА УПРАВЛІННЯ ФІНАНСОВИМИ РИЗИКАМИ ПІДПРИСМСТВА SYSTEM OF FINANCIAL RISKS MANAGEMENT OF THE ENTERPRISE}

В процесі ведення підприємницької діяльності кожен підприємець зіштовхується із певними непередбачуваними витратами, які були обумовлені певними ризиками. Ці загрози викликають цілком зрозумілу потребу в створенні системи оцінки ступенів ризику та прийняття заходів для подальшого зниження, страхування або елімінування потенційних ризиків. Така система ризиків допоможе уникати систематичних проблем, так як в більшості випадків, підприємства систематично постають перед певним видом ризиків. Наприклад, втратами через швидке та довготривале зростання рівня інфляції, а також через значні коливання на валютному ринку, тощо. Отже, в такому випадку доцільним є проведення аналізу сукупності факторів ризику, що призводять до настання значних фінансових втрат.

Фінансовий ризик - це ймовірність виникнення непередбачених фінансових втрат у ситуації невизначеності умов фінансової діяльності підприємства. Фінансовий ризик $\epsilon$ результатом вибору його власниками чи менеджерами альтернативного фінансового рішення, спрямованого на досягнення бажаного цільового результату фінансової діяльності при вірогідності настання економічного збитку (фінансових втрат) через невизначеність умов його реалізації [1].

Щоб визначити сили впливу певного ризику відносно підприємства, необхідно здійснити початкову оцінку фінансового стану підприємства, дослідивши при цьому динаміку зміни результатів цих показників за певний період. Проводячи аналіз основних складових фінансового ризику, бажано розглядати їх в залежності від джерела виникнення, щоб безпосередньо зрозуміти чи проблема викликана внутрішніми чинниками підприємства або зовнішніми. 
В окремих випадках, коли фінансово-економічна діяльність піддається впливу дій факторів, коливання яких є майже непередбачуваним, потрібно заздалегідь передбачити відповідну нормативно-методичну базу. Доцільно долучитися певною системою заходів, яка б використовувалась при настанні певних обставин, наприклад, при перевищенні меж припустимих коливань певних факторів фінансового ризику.

Однією $з$ найважливіших властивостей системи моніторингу є швидкість реакція на виникнення непередбачуваних ризиків. Сутність даної властивості полягає у визначенні в поточний момент часу характеристики цілей та завдань, які були поставлені при плануванні системи підприємства, та пошук наявних для використання фінансових ресурсів. В даному випадку від системи моніторингу очікується визначення конкретних відхилень у стані факторів впливу на фінансову частину підприємства, причин настання відхилень, а також найшвидше визначення відповідних наслідків, що можуть виникнути в результаті подібних відхилень.

Г. В. Чернова пропонує наступні види методів зниження фінансових ризиків: метод відмови від ризику; метод зниження частоти збитку або запобігання збиткам; метод прийняття ризику на себе; метод зменшення розміру збитків; метод розподілу ризику; метод аутсорсингу ризику; метод запобігання збиткам; страхування; самострахування; метод передачі ризику [2].

Систематизувавши існуючі в літературі класифікації методів зниження фінансових ризиків, вважаємо за доцільне виділити найважливіші 3 них: ухилення від ризику; перейняття ризику на себе; передача ризику; розподіл ризиків; об'єднання ризику; диверсифікація; лімітування; страхування; самострахування; хеджування; використання внутрішніх фінансових нормативів; інші методи мінімізації фінансового ризику.

\section{Перелік використаних джерел:}

1. Бланк И. А. Финансовый менеджмент: Учебный курс / И. А. Бланк. - 2-е изд., перераб. и доп. - К.: Эльга, Ника-Центр, 2004. — 552 с.

2. Чернова Г.В. Управление рисками: Учебное пособие / Г.В. Чернова, А. А. Кудрявцев. - М.: ТК Велби, Изд-во Проспект, 2003. - 160 с.

УДК 338

Бажанова Наталія

кандидат економічних наук, доцент кафедри економіки та фінансів

Тернопільський національний технічний університет імені Івана Пулюя

м. Тернопіль, Україна

Bazhanova Nataliia

$\mathrm{Ph}$. D, Associate Professor

Department of Economics and Finance

Ternopil Ivan Puluj National Technical University

Ternopil, Ukraine

\section{ТЕНДЕНЦІЇ ТА ПЕРСТПЕКТИВИ ПРИРОДНЬОГО ПРИРОСТУ НАСЕЛЕННЯ В УКРАЇНI \\ TRENDS AND PROSPECTS OF NATURAL POPULATION IN UKRAINE}

Постановка проблеми. Сьогодні іде тенденція до стрімкого зменшення народжуваності в Україні, населення зменшується, а нація старіє з кожним роком все більше. Згідно зі статистикою до 1994 року кількість українців зростало, але потім почало стабільно падати. На сьогодні, населення України становить 42,5 млн. осіб. 
Мета статті. 3'ясувати причини та фактори, які впливають на зменшення народжуваності в Україні. Визначити роль держави у стабілізації даних процесів.

Виклад основного матеріалу. Основними факторами, які негативно впливають на збільшення кількості населення в країні $є$ економічна та політична кризи, а також війна на сході України. А також, виїзд за кордон талановитого, працездатного населення, яке мало б розвивати та збагачувати країну. Найбільше українських мігрантів у Польщі, Німеччині, Чехії, Італії та Швеції.

Працюючого населення не вистачатиме для того, щоб фінансово підтримувати людей пенсійного віку, що може викликати соціальну кризу.

Негативним фактором є і те, що кількість вчених в Україні теж зменшується, отже в найближчому майбутньому, розвивати технології, теж буде нікому.

Незважаючи на позитивну тенденцію зменшення смертності, показники народжуваності не збільшуються, і тому показники загальної чисельності населення теж продовжуватимуть зменшуватись.

Так, до 2050 року населення України зменшиться до 32 мільйонів, що є негативним природнім приростом населення. Згідно зі статистикою у більшості українських сімей виховується лише одна дитина (70 \%).

Величезною проблемою є катастрофічна кількість абортів. На загальну кількість вагітностей, припадає четвертина переривання вагітностей.

Висновок. Усі вищезгадані проблеми, держава має регулювати на законодавчому рівні, оскільки ми на шляху демографічної катастрофи в подальшому, все це може призвести до ще більш глибокої соціально-економічної кризи.

\section{Перелік використаних джерел:}

1. Скоробогатова Н. Є. Регулювання міжнародної міграції трудових ресурсів в умовах глобалізації / Н. С. Скоробогатова, Л. С. Карнажук // Сучасні проблеми економіки і підприємництво. - 2017. - Вип. 20. - С. 31-39.

Винник Тетяна кандидат економічних наук, доцент кафедри економіки та фінансів Тернопільський національний технічний університет імені Івана Пулюя м. Тернопіль, Україна

Vynnyk Tetiana

$\mathrm{PhD}$ in Economics, Associate Professor Ternopil Ivan Puluj National Technical University

Ternopil, Ukraine

\section{СПОЖИВЧИЙ КОШИК ЯК КРИТЕРІЙ РІВНЯ ЖИТТЯ НАСЕЛЕННЯ CONSUMER BUSKET AS CRITERION LEVEL OF LIVING}

У більшості країн основним критерієм, що характеризує рівень життя громадян $є$ вартість споживчого кошика. Як і в інших європейських країнах, так і в Україні за формування споживчого кошику несе відповідальність уряд. Нині там налічується 250 товарів і послуг (В Свропі споживчий кошик - набір різних товарів і послуг - включає від 300 найменувань до декількох тисяч, залежно від країни [2]).

Споживчий кошик - це набір продуктів харчування, непродовольчих товарів і послуг для основних соціальних і демографічних груп населення. До споживчого кошика входять товари, що споживаються окремою людиною чи сім'єю протягом місяця або року. Від вартості споживчого кошика залежать формування державного та місцевих бюджетів, обсяг соціальної допомоги, а також прожитковий мінімум та мінімальна заробітна плата і пенсія 
[4] (станом на 1.04.2019 прожитковий мінімум становить 1921 грн., розмір мінімальної заробітної плати - 4173 грн., мінімальної пенсії - 1497 грн.) [3]. Слід зазначити, що в середньому понад 60 \% зарплати ми витрачаємо на харчування, причому ці витрати не мають перевищувати третини прожиткового мінімуму. Для прикладу в Іспанії, Франції та Німеччині витрати на продукти не перевищують $13 \%$. А загалом мешканці Європи витрачають на їжу менше $20 \%$ [1]. Щодо практики в європейських країнах, то там прожитковий мінімум не прив'язаний до кошика споживчих товарів. Споживчий кошик служить передовсім маркером інфляції, тобто аналізуючи товари та послуги, що входять до його складу, легко відстежити, як змінюються ціни, рівень інфляції і т.д. I на основі цього коригуються соціальні стандарти [2].

Востаннє уряд переглядав споживчий кошик у жовтні 2016 року, а до цього аж у 2000 році. Водночас, згідно із законом, споживчий кошик має переглядатись кожні 5 років [5]. Важливо, що у 2018 році Київський апеляційний адміністративний суд ухвалив рішення, яким підтвердив незаконність споживчого кошика в Україні і зобов'язав уряд переглянути його склад та нормативи, які є необгрунтованими та занижують стандарти життя українців.

Надзвичайно важливим аспектом, при розрахунку вартості споживчого кошика $\epsilon$ розуміння його впливу на зростання економіки країни. Так, зідно $з$ даними Індексу соціального розвитку, розробленого американською неурядовою організацією «Social Progress Imperative» за підтримки компанії «Делойт», за рівнем життя населення Україна посідає 64 місце за рівнем соціального розвитку серед 146 країн світу. Індекс визначає рейтинги країн на базі показників, що мають безпосередній вплив на якість життя людей. За рівнем Індексу соціального розвитку Україна посіла місце між Кубою (63) і Македонією (65) та залишається у групі країн із розвитком вище середнього. Незначне покращення показників України відбулося у категоріях «Основні потреби людини», «Основи благополуччя» та «Можливості». Рівень ВВП України на душу населення підвищився із \$7,457 у 2017 році до \$7,668 у 2018 році. За результатами цьогорічного Індексу серед країн СНД, Україна поступилася Білорусі (46), Вірменії (55) та Росії (60). Значним покращенням Індексу вирізнилась Білорусь. Останню сходинку за рівнем соціального розвитку серед країн СНД посідає Таджикистан (106) [6].

Індекс соціального розвитку - це перша цілісна оцінка рівня соціального розвитку країни незалежно від економічних чинників. Індекс складається 3 низки показників соціального розвитку та довкілля, що відображають три напрями соціального розвитку: базові людські потреби, добробут і можливості. Індекс соціального розвитку за 2018 рік охоплює дані 146 країн за 51 показником, що становить 98 \% усього населення світу. Індекс було розроблено як органічне доповнення для показника ВВП та інших економічних індикаторів для забезпечення більш цілісного уявлення про загальний рівень розвитку країн. Індекс соціального розвитку також пропонує практичний спосіб відстеження досягнутого прогресу порівняно з цілями ООН у сфері сталого розвитку.

Як бачимо, соціальні стандарти, які діють сьогодні в Україні є відображенням не лише рівня економічного розвитку нашої держави, а й якості життя українців.

\section{Перелік використаних джерел:}

1. Василик А. В. Споживчий кошик в Україні: реалії та необхідність удосконалення базових соціальних стандартів [Електронний ресурс] / А. В. Василик, К. П. Кузьменко. Режим доступу: http://bses.in.ua/journals/2017/17_2017/36.pdf;

2. Жебрацькй споживчий кошик: суд припинив знущання уряду 3 українців [Електронний ресурс] - Режим доступу: https://m.znaj.ua/society/203371-zhebrackyspozhivchiy-koshik-sud-pripiniv-znushchannya-uryadu-z-ukrajinciv;

3. Прожитковий мінімум 2019 [Електронний ресурс] - Режим доступу: http://www.buhoblik.org.ua/kadry-zarplata/oplata-truda/2824-2824-prozhitkovij-minimum.html; 
4. Сопоцько О. Ю. Продукти харчування повсякденного попиту як складові споживчого набору [Електронний ресурс] / О. Ю. Сопоцько. - Режим доступу: http://nbuv.gov.ua/UJRN/Vntu_2011_24\%281\%29_100;

5. Споживчий кошик в Україні: що він передбачає та чи відповідає прожитковому мінімуму [Електронний ресурс] - Режим доступу: https://nv.ua/ukr/ukraine/events/spozhivchijkoshik-v-ukrajini-shcho-vin-peredbachaje-ta-chi-vidpovidaje-prozhitkovomu-minimumu2489731.html;

6. 2018 Social Progress Index [Електронний ресурс] - Режим доступу: https://www.socialprogress.org/? code=UKR.

УДК 330.34:332.142

Гречко Алла

кандидат економічних наук, доцент, доцент кафедри економіки і підприємництва Національного технічного університету України «Київський політехнічний інститут імені Ігоря Сікорського»

м. Київ, Україна

Alla Hrechko

Ph.D, Associate Professor, Associate Professor of the Department of Economics and Entrepreneurship National Technical University of Ukraine "Igor Sikorsky Kiev Polytechnic Institute" Kyiv, Ukraine

\section{ФІСКАЛЬНІ СТИМУЛИ ЯК ПЕРЕДУМОВА ПІДВИЩЕННЯ КОНКУРЕНТОСПРОМОЖНОСТІ РЕГІОНІВ FISCAL STIMULATIONS AS A PREDICTION OF INCREASING THE COMPETITIVENESS OF REGIONS}

Сучасні глобалізаційні виклики розвитку світового господарства актуалізують застосування урядами країн різних механізмів підвищення конкурентоспроможності господарюючих суб'єктів. Одним із таких механізмів є фіскальна державна політика. Для України, в якій відбуваються реформи у напрямі децентралізації владних повноважень для зменшення асиметричності соціально-економічного розвитку стають актуальними питання використання фіскальних стимулів для підвищення конкурентоспроможності регіональних суб'єктів.

Фіскальна політика держави повинна бути спрямована на формування сприятливого інституційного середовища функціонування господарюючих суб'єктів та заснована на системі економічних стимулів для підвищення їх конкурентоспроможності.

Виходячи із семантики слова «стимул», економічний зміст даного поняття включає в себе сукупність заходів, направлених на спонукання до конкретних дій або каталізацію окремих процесів. На практиці фіскальні стимули активізують діяльність підприємств, створюючи резерви до збільшення прибутковості шляхом скорочення витратної складової як за рахунок використання можливостей прямого субсидіювання державою або за рахунок впровадження податкових пільг, що підвищує їх конкурентоспроможність, у тому числі, й на світовому ринку.

На наш погляд, при фіскальному стимулюванні, що включає в себе широкий спектр засобів, застосування яких визначається, в першу чергу, об'єктом стимулювання, організаційно-правовою формою та юридичним статусом платника податків, видом діяльності, регіональною ознакою та соціальним значенням, повинно бути спрямовано на інноваційну сферу. Саме стимулювання інноваційної сфери сприятиму підвищенню 
конкурентоспроможності регіонів, що, у свою чергу, впливатиме на зменшенні асиметричності соціально-економічного розвитку регіонів та підвищення рівня стійкого розвитку країни в цілому $[1$, с. 46$]$.

Актуальність використання фіскальної стимулів для підвищення конкурентоспроможності регіонів у рамках інноваційної політики посилюється наявністю системних перешкод розвитку інноваційної сфери, причини виникнення яких різняться від наслідків тривалого існування командно-адміністративної системи та соціалістичної ідейної спадщини до сучасних глобальних проблем, що $\epsilon$ типовими для розвинутих ринкових економік. Серед них відзначимо:

- низький рівень розвитку інноваційної інфраструктури як наслідок неефективної роботи основних іiі інститутів;

- низькі темпи оновлення основних засобів;

- слабке нормативно-правове забезпечення процесів трансферу технологій;

- формалізація законодавчо визначених пріоритетів розвитку, внаслідок індиферентного ставлення держави до необхідності підтримки інновацій та нецільового використання бюджетних коштів.

До загальних недоліків, які стосуються стратегії вибору фіскальних стимулів при формуванні системи податкових преференцій, можна віднести:

- встановлення їх без прив'язки до рівня та завдань розвитку територій;

- надання податкових преференцій без закріплення за суб'єктами господарювання яким вони надаються конкретних результативних показників (соціально-економічного характеру розвитку регіонів) тощо [2, с. 31].

Отже, фіскальна політика представляє собою складну систему взаємозв'язків держави, регіонів та інших суб'єктів господарювання, що полягає у постійному пошуку балансу інтересів. Одним із напрямків для підвищення конкурентоспроможності регіонів та iii суб'єктів, в якому ефективно реалізуються підходи фіскального стимулювання $\epsilon$ інноваційна сфера. Але, необхідно зауважити, що впровадження того чи іншого фіскального стимулу вимагає аналізу вартісних аспектів їх впровадження.

\section{Перелік використаних джерел:}

1. Тульчинська С. О. Перспективи та домінанти розвитку інтелектуальноінноваційної системи регіонів України: монографія / С. О. Тульчинська. - Херсон: Ви-во «ПП Вишемирський В. С.», - 2014. - 210 с.

2. Хвесик М. Парадигмальний погляд на концепт сталого розвитку України / М. Хвесик, І. Бистряков // Економіка України. - 2012. - № 6. - С. 4-12. 
Ілляшенко Сергій

зав. каф. маркетингу та УІД, Сумський державний університет

м. Суми, Україна

доктор хабілітований, професор

Економіко гуманітарний університет

м. Бєльсько-Бяла, Польща

Illiashenko Sergii

Head of the Department of Marketing and MIA, Sumy State University

Sumy, Ukraine

Dr. hab, Professor, University of Economics and Humanities

Bielsko-Biala, Poland

\section{НОВА ОРГАНІЗАЦІЙНА МОДЕЛЬ ФУНКЦІОНУВАННЯ ВИПУСКОВОЇ КАФЕДРИ УНІВЕРСИТЕТУ: ЗДОБУТКИ І ПРОТИРІЧЧЯ \\ THE NEW ORGANIZATIONAL MODEL OF GRADUATE DEPARTMENT OF UNIVERSITY: ACHIEVEMENTS AND CONTRADICTIONS}

Аналіз досвіду провідних вітчизняних і зарубіжних університетів свідчить, що їх успіх у вирішальній мірі залежить від результативності діяльності випускових кафедр. На них зосереджується основна наукова, навчальна, профорієнтаційна та ін. робота. Загалом, на рівні випускової кафедри виконується порядку 10 (і більше) видів робіт у т.ч.: проведення навчального процесу i його організаційно-методичне забезпечення; виконання наукових досліджень і оприлюднення їх результатів, підготовка наукових кадрів, експертиза наукових розробок; профорієнтаційна діяльність; співпраця з роботодавцями; організаційна робота (на кафедрі, факультеті, університеті, у різноманітних структурах МОН типу НМК, журі конкурсів наукових робіт тощо); участь у міжнародних проектах; надання платних послуг; просування кафедри і спеціальностей, у т.ч. в інтернет; підготовка наукових і навчальнометодичних видань; підтримання контактів з випускниками минулих років і т.п. У цілому ж це може включати кілька сотень різнопланових робіт [1]. Практика свідчить, що персонал типової кафедри 3 15-20 осіб при традиційній функціональній організаційній структурі системи управління якісно виконати їх не зможе.

Виходячи 3 цього запропоновано i апробовано на протязі 14 років кафедрою маркетингу та УІД СумДУ [2] принципово інший підхід до організації діяльності випускової кафедри, який передбачає поєднання відомої проектно-матричної структури у поєднанні 3 пульсуючою (у кількісному плані працівників, що приймають участь у проектах) [3]. Була також сформована інноваційна культура як соціально-культурний механізм регулювання $\mathrm{i}$ стимулювання інноваційної поведінки персоналу. Це дозволило забезпечити якісне виконання практично усіх зазначених видів робіт. Можна навести лише деякі досягнуті завдяки цьому показники: на кафедрі акредитовано 3 магістерські програми, аспірантура $\mathrm{i}$ докторантура 33 спеціальностей; безпосередньо співробітниками кафедри видано більше 100 підручників, навчальних посібників, монографій (у т. ч. за кордоном); кафедрою створено науковий журнал, що ввійшов до Web of Science; започатковано і проведено більше 10 Міжнародних наукових конференцій; опубліковано у вітчизняних і зарубіжних журналах більше 1000 статей, у т.ч. близько 100 у Scopus i Web of Science; співробітниками кафедри захищено 4 докторські і 27 кандидатських дисертацій; студенти, підготовлені на кафедрі стали переможцями і призерами більше 100 Всеукраїнських предметних олімпіад, конкурсів наукових робіт, конкурсів дипломних проектів тощо, а також більше 20 міжнародних конкурсів наукових робіт; отримано і виконано 6 Грантів Президента України для молодих науковців; виконано 7 держбюджетних і 9 господоговірних наукових тем; на постійній основі провадиться викладання і стажування співробітників у зарубіжних університетах і т.п. 
Проте по мірі зростання здобутків кафедри почали наростати протиріччя з існуючою ієрархічною системою управління факультетом та університетом взагалі. Основні 3 них: директивні вказівки (що суперечать сутності зазначеної інноваційної організаційної структури) про виділення так званих відповідальних за види діяльності, оскільки слідуючи цій логіці персонал слід було збільшити у десятки раз, що неможливо; прагнення контролювати процес, а не результат (це взагалі властиво більшості університетів України); відволікання персоналу на чисельні багатогодинні наради, семінари і.т.п., коли достатньо окреслити завдання і час та проконтролювати результат; бюрократичні перепони, наприклад, з підписанням у СумДУ вже підписаної замовником угоди, що викликало його негативну реакцію, аж до відмови від співпраці; різке зростання кількості нормативних документів (до 100 нових на місяць), весь сенс існування яких зводиться до дріб'язкового контролю кожного кроку, при цьому сам результат вже нікого не цікавить; некомпетентне втручання керівництва у виконання наукових та освітніх проектів (не будучи фахівцями при цьому фахівцями у даних галузях), що неможливо і непотрібно, оскільки, як говорив Стів Джобс толкових працівників наймають не задля того щоб їм диктувати, що потрібно робити, а щоб вони це говорили нам.

Проведений аналіз свідчить, що зазначені протиріччя спричинені самим фактом існування відносно незалежної і нетипової структури, яка не завдяки, а всупереч традиційній ієрархічній системі управління забезпечує значно кращі результати. Її можуть взяти за приклад інші і тоді виявиться, що існуючий апарат і методи управління доведеться змінювати, а до цього не готові. Як результат - грубий тиск на кафедру, з вимогами бути як всі, не виділятися. Доводи, що при цьому різко падає результативність діяльності, не сприймаються. І це мова йде про один з дійсно провідних університетів України.

Практика підтвердила істину, що змінити структуру знаходячись усередині неї неможливо. Необхідно щоб МОН України вніс відповідні зміни у свою нормативну базу, що практично неможливо, або ж створювати університети нового типу «з нуля», що також неможливо, зважаючи на наявні ринкові бар'єри.

Звичайно, важко робити висновки спираючись на досвід одного університету (його окремої кафедри). Проте спілкування 3 колегами з університетів різних регіонів України $\mathrm{i}$ різних форм власності свідчить про схожість проблем. I якщо їх не вирішувати, то в університетах залишаться низькокваліфіковані фахівці, які знають, що знайти роботу в іншій сфері вони не зможуть. Високваліфіковані творчі викладачі і співробітники підуть у інші сфери, або ж виїдуть за кордон, що вже зараз і відбувається. А це приведе до того, що одні 3 небагатьох конкурентних переваг, що характеризують високий інтелектуальний потенціал України - відсоток населення віком 30-34 роки, які мають закінчену вищу освіту, якість освіти вище середньоєвропейської тощо [4, 5] - будуть втрачені з усіма наслідками, що випливають $з$ цього.

Подальші дослідження повинні бути спрямованими на розроблення i наукове обгрунтування механізмів стимулювання впровадження у діяльність вітчизняних університетів передового світового досвіду, у т.ч. інноваційних форм організації науковоосвітнього процесу.

\section{Перелік використаних джерел:}

1. Illiashenko S. M. Rationalization of organizational structure at the graduate department / S.M. Illiashenko // Human Capital Management: innovative aspects in the transformational economy monograph / edited by Dr. of Economics, Prof. Prokopenko O., Ph.D in Economics and Politic Science Homberg R., Ph.D in Economics Kotenko O. - Ruda Śląska : Drukarnia i Studio Graficzne Omnidium, 2018. - P. 7-17.

2. Офіційний сайт кафедри маркетингу та управління інноваційною діяльністю СумДУ. URL : http://km.fem.sumdu.edu.ua

3. Тофлер Э. Метаморфозы власти / Э. Тофлер ; пер. с англ. - М. : ООО "Издательство ACT", 2004. - 669 c. 
4. European Innovation Scoreboard 2016 [Електронний ресурс]. - Режим доступу http://ec.europa.eu/growth/industry/innovation/facts-figures/scoreboards_en

5. Bloomberg назвав нову позицію України у рейтингу найбільш інноваційних економік світу. URL: Режим доступу: https://informator.news/bloomberg-nazvav-novu-pozytsiyu-ukrajinyu-rejty nhu-najbilsh-innovatsijnyh-ekonomik-svitu/

УДК 33(477)-043.86:330.837

Клемпарський Микола доктор юридичних наук., професор, професор кафедри загально-правових дисциплін Донецького юридичного інституту МВС України

Mykola Klemparskyi

Doctor of Science, Low, professor, professor of the Department of General-legal disciplines

Donetsk Low Institute

Donetsk, Ukraine

Тетяна Ларіна

доктор економічних наук, доцент завідувач кафедри агрологістики і управління ланцюгами постачань Харківського національного технічного університету сільського господарства ім. П. Василенка Харків, Україна

Tetiana Larina

Doctor of Science, Economics, associate professor Head of the Department of Agrologistics and Supply Chain Management Kharkiv Petro Vasylenko National Technical University of Agriculture Kharkiv, Ukraine

\section{ЕЛІТА ЯК СУБ'ЄКТ ІНСТИТУЦІЙНОЇ ДИНАМІКИ ELITE AS A SUBJECT OF INSTITUTIONAL DINAMICS}

Феномен еліт не є новим предметом дослідження у світовій економічній теорії. В Україні посилення інтересу до цієї проблематики відбулося на початку 2000-х років, однак більшість робіт мала публіцистичний, політологічний, соціологічній, філософський характер. Економічні аспекти проблеми розробляються в рамках інституційної та неоінституційної теорій і представлені рядом зарубіжних та вітчизняних вчених, серед яких Олсон М. [1], Аджемоглу Д., Робинсон Д. [2], Гриценко А., Яременко О. [3], Норт Д. [4], Олейник А. [5], Полтерович В. [6] тощо.

В інституційній теорії генезис інститутів розуміється як процес свідомого вибору 3 боку зацікавлених дієвих осіб. Хто здійснює цей вибір? Еліти як вищий прошарок будь-якої системи Його функцією саме і є управління системою в цілому або тими чи іншими іiі підсистемами, визначення норм і цінностей, що слугують відтворенню системи і її розвитку в певному напрямку. Формування еліти в Україні стало результатом інкрементного розвитку.

Сучасна політична та економічна система в Україні демонструє відповідність параметрам суспільних порядків обмеженого доступу. Причому сформувалися вони задовго до набуття нашою державою незалежності, а саме були успадковані з радянських часів. Наприкінці 80-х років 20 ст. (внаслідок дії цілої низки внутрішніх та зовнішніх факторів) інституціоналізовані за десятиріччя радянської влади умови суспільного договору щодо розподілу ренти були порушені. Це призвело до дезінтеграції соціуму, руйнування його економічної, політичної та ціннісної підсистем. Виникнення збройних конфліктів у низці пострадянських держав стало результатом втрати елітами контролю над застосуванням насильства. Останні виявилися неспроможними досягти домовленості та запропонувати новий суспільний договір. Насильство в Україні розгорнулося у формі криміналізації 
соціально-економічних відносин. Боротьба старих та нових еліт за розподіл державних активів та сфер впливу в умовах слабкості державних інституцій набула характеру кримінальних війн. Поступово жорстка конкуренція визначила переможців. Сформувалися потужні центри економічної влади - неформальні фінансово-промислові групи, які згодом перетворилися на справжні олігархічні клани.

На сьогодні українська еліта - це симбіоз влади і власності, політики та економіки, тобто суб'єктивована як олігархія. Західні експерти - прибічники неокласичної теорії (фактичні розробники стратегії економічних реформ в Україні), розглядають виникнення олігархії як побічний ефект трансформаційних процесів. Проте з погляду інституціоналізму це цілком закономірний результат розвитку порядку з обмеженим доступом, що існував $\mathrm{i}$ продовжує існувати в Україні.

Основна частина статків олігархічних еліт в Україні зосереджена у сировинних галузях. Саме тут найлегше видобувається рента. Оцінюючи роль сучасних національних еліт, можна констатувати їх особливо негативний вплив на процеси модернізації економіки України, підвищення іiі конкурентоспроможності в глобальному вимірі. Інновації як сутнісне ядро сучасного світового господарства розглядаються суб'єктами еліт як фактор небезпеки, що має потенціал формування альтернативних центрів влади. Консервується сировинна спеціалізація вітчизняної економіки, перспективи іiі розвитку у наукоємних галузях (де основою прибутків $\epsilon$ інновації) без зміни соціального порядку виглядають ілюзорними.

Граничними умовами набуття елітою в Україні потенціалу створення інституційної основи порядків відкритого доступу є:

- підтримка безособових еліт (наприклад, ідеологічних партій). Це питання більш соціологічне, хоча має і економічну складову;

- верховенство права. В Україні закони є певною умовністю для представників еліт через існуючі можливості систематичного їх порушення;

- консолідований контроль над організаціями, що здатні на насильство;

- формування потужного середнього класу. Простежується наступний ланцюг взаємозв'язків: шанси побудови системи інклюзивних інститутів тим менше, чим менше кількісна характеристика еліти. Ї̈ розширення можливе лише за рахунок амбіційних представників середнього класу.

\section{Перелік використаних джерел:}

1. Olson, Mancur jr. The Devolution of the Nordic and Teutonic Economies // The American Economic Review, Vol. 85, № 2; Papers and Proceedings of the Hundredth and Seventh Annual Meeting of the American Economic Association Washington, DC, January 6-8, 1995. (May. 1995). PP. 22-27.

2. Аджемоглу Д., Робинсон Д. А. Почему одни страны богатые, а другие бедные. Происхождение власти, процветания и нищеты / Дарон Аджемоглу, Джеймс А. Робинсон : [перевод с английского Дмитрия Литвинова, Павла Миронова, Сергея Сановича]. - Москва : Издательство АСТ, 2015. - 575, [1] с.

3. Гриценко А. А., Артемова Т. И., Яременко О. Л. Институциональная архитектоника и динамика экономических преобразований. - Х.: Форт, 2008. - 938 с.

4. Норт Д. К. Институты, институциональные изменения и функционирование экономики. - М.: Фонд экономической книги «Начала», 1997. — 180с. — (англ. Institutions, Institutional Change and Economic Performance, 1990)

5. Олейник А. Н. Институциональная экономика: Учебное пособие. - М.: ИНФРАM, 2013. - 416 c.

6. Полтерович В. М. Современное состояние теории экономических реформ [Режим доступу: https://cyberleninka.ru/article/n/sovremennoe-sostoyanie-teorii-ekonomicheskih-reform] 
Козак Зоряна

студентка групи ПФм-51

Тернопільський національний технічний університет імені Івана Пулюя,

Тернопіль, Україна

Науковий керівник: Винник Тетяна

к.е.н., доцент

Тернопільський національний технічний університет імені Івана Пулюя,

Тернопіль, Україна

Kozak Zoriana

student of group ПФМ-51

Ternopil Ivan Puluj National Technical University

Ternopil, Ukraine

Scientific supervisor: Tetiana Vynnyk

$\mathrm{PhD}$, Associate Professor

Ternopil Ivan Puluj National Technical University

Ternopil, Ukraine

\section{ПРИНЦИПИ ФОРМУВАННЯ БЕЗПЕКИ БАНКІВСЬКОЇ ДІЯЛЬНОСТІ PRINCIPLES OF FORMING SAFETY OF BANKING ACTIVITIES}

Банківська система $є$ найважливішою складовою фінансової сфери держави, на діяльність якої впливає безліч факторів, серед яких велику роль відіграє банківська безпека. Вона є складною системою, кожен елемент якої призначений для забезпечення діяльності банків і банківської системи на різних рівних їі діяльності.

На сьогоднішній день існує велика кількість загроз безпеці банку, і поширюються вони на всі його сфери, саме тому поняття банківської безпеки потребує комплексного підходу до аналізу, регулювання, і створення умов для мінімізації або повного їх усунення.

Сьогодні банки змушені здійснювати свою діяльність в умовах нестабільності і невизначеності. На результати їх діяльності впливають як внутрішньобанківські фактори так і загальноекономічні, такі як нестабільність економічної ситуації в країні, шахрайство, недосконалість банківського законодавства, корупція та багато інших. Саме тому керівні органи повинні вживати заходів по збереженню безпеки банків.

Забезпечення безпеки банку - це діяльність його персоналу, спеціального підрозділу власної безпеки, державних правоохоронних органів та інших структур, спрямована на запобігання можливого порушення його нормального функціонування [2].

В банківській діяльності науковці виділяють чотири рівні безпеки: особиста стосується безпеки і комфортних умов праці кожного конкретного працівника, шляхом проведення індивідуальних навчань; колективна безпека означає забезпечення спокійної i ефективної роботи всіх підрозділів банку. Інформаційна направлена на формування i організацію захисту інформаційних ресурсів банку. I основним видом банківської безпеки $\epsilon$ економічна. Вона спрямована на забезпечення умов в яких банки можуть проводити роботу 3 формування i використання своїх фінансових i кредитних ресурсів, залучати нових партнерів, прогнозувати свій майбутній розвиток, та багато іншого.

У банках повинні бути створені відповідні служби, основними функціями яких $є$ моніторинг усіх ризиків і небезпек діяльності і оперативного реагування на них. При цьому вони повинні здійснювати свою діяльність відповідно до норм законодавства. Керівним органам в свою чергу потрібно забезпечити ці служби необхідними засобами i повноваженнями для безперервного їх функціонування i централізовано здійснювати організацію роботи. Найголовнішим принципом безпеки повинно бути те, що всі учасники процесу забезпечення безпеки банківської діяльності повинні бути ознайомлені 3 
відповідними посадовими інструкціями і нести відповідальність за дотримання ними поставлених завдань і вимог.

Європейські країни в цілях забезпечення фінансової безпеки банків використовують різні способи захисту інформації, використовуючи як власні служби так і залучаючи зовнішніх партнерів, використовуючи допомогу міжнародних органів інформаційної безпеки, створюючи підрозділи по забезпеченню захисту проти крадіжок комерційних та клієнтських даних.

У світовій практиці для профілактики загроз і захисту фінансових систем створюються спеціалізовані об'єднання фінансових інспекцій і правоохоронних органів, які працюють на міжнародному рівні. Така практика стає все більш поширеною в цілому світі, дані служби здатні проводити повний моніторинг банківських операцій в режимі реального часу, забезпечуючи тим самим безперервну роботу як самих установ банків так і збереження клієнтських коштів і даних. Так наприклад, на сьогоднішній день США та Канада стали лідерами серед країн у протидії кіберзагрозам, оскільки використовуючи IT спільноту в рамках співпраці протидії шахрайським операціям, збору та верифікації інформації, топ менеджмент банків досягнув значних результатів у оперативності та якості розпізнавання ризиків в рамках кредитних та фінансово-господарських операцій [1]. За час дії цієї системи взаємовідносин були усунені порушення діяльності банків на мікрорівні, зокрема щодо зловживання працівниками своїх повноважень на робочих місцях та намагання викрадення цінної інформації та документів із бази даних банків.

Відомий англійський фінансовий аналітик старший віце-президент компанії Business Computing World UK Марк Рівз розробив 5 простих засобів запобігання кібер-атак на банки:

1. Систематичне оцінювання ризиків онлайнових транзакцій на відповідність чуттєвості зміни інформації (тип клієнту, обсяг операції, якість обслуговування, мобільний засіб та ін.).

2. Підвищення стандартів аутентифікації інформації. Відмовитися від розповсюджених дворівневих методів ідентифікації прізвище-пароль на користь передових систем виявлення шахрайства на основі поведінки, які можуть автоматично виявляти транзакції або веб-сайт навігацій аномалії в реальному масштабі часу.

3. Застосування багаторівневого підхіду до перевірки даних: нашарування різних, що доповнюють один одного технологій безпеки, таких, як сувора аутентифікація, поведінкове виявлення шахрайства поза зоною перевірки транзакції, мобільна перевірка справжності, розширена перевірка персоніфікації, SSL цифрові сертифікати.

4. Впровадження передових методів аутентифікації: перевірка мобільного на основі транзакцій, аутентифікації динамічних пристроїв - в тому числі одноразові сеансові куки і цифрові відбитки пальців та ін.

5. Підвищення рівня обізнаності та освіти клієнтів. Частину коштів банки повинні витрачати на розробку доступних освітніх проектів для своїх клієнтів. Це має подвійні наслідки: підвищення рівня безпеки та створення з клієнтами довготермінових партнерських відносин [2].

Ці методи також можна застосовувати при захисті стратегічно важливої інформації для життєдіяльності та розвитку самого банку.

Отже, основною метою безпеки банківської діяльності є створення сприятливого середовища для ефективної роботи банку, реалізації поставлених завдань і недопущення втрати ним потенційного прибутку, досягненню якої повинна сприяти чітко сформована система управління на всіх рінях організації.

\section{Перелік використаних джерел:}

1. Гребенюк Н. О. Фінансова безпека банків: система розпізнання загроз та усунення ризиків / Н. О.Гребенюк // Вісник Харківського національного університету імені В. Н. Каразіна. Серія : Економічна. - 2016. - Вип. 91. - С. 53-64;

2. Корченко А. О. Банківська безпека / А. О. Корченко, Л. М. Скачек, В. О. Хорошко // Підручник. Банківська безпека [Електронний ресурс] - режим доступу: 
http://elar.naiau.kiev.ua/bitstream/123456789/1714/1/\%D0\%91\%D0\%90\%D0\%9D\%D0\%9A$\% \mathrm{D} 0 \% 91 \% \mathrm{D} 0 \% 95 \% \mathrm{D} 0 \% 97 \% \mathrm{D} 0 \% 9 \mathrm{~F}-1 . \mathrm{pdf} ;$

3. Передумови створення оптимальної моделі забезпечення фінансової безпеки банку на базі світового досвіду [Електронний ресурс] - режим доступу: http://www.investplan.com.ua/pdf/2_2018/11.pdf.

УДК 338.001 .36

Кондратюк Надія студентка 4 курсу, спеціальності «Фінанси та кредит»

Науковий керівник: Коляда Тетяна к.е.н., с.н.с., доцент кафедри фінансів Університет державної фіскальної служби України, м. Ірпінь, Україна

Nadiia Kondratiuk fourth year student, «Financial and banking system» department Scientific supervisor: Tetiana Koliada $\mathrm{PhD}$ (Candidate of Sciences (Economics)), Associate Professor, Department of Finance, University of State Fiscal Service of Ukraine

\section{ОЦІККА ВІДКРИТОСТІ ЕКОНОМІКИ УКРАЇНИ EVALUATION OF THE OPENNESS OF ECONOMY OF UKRAINE}

Економіка України є економікою відкритого типу, яка характеризується значними обсягами експорту та імпорту. Значно вищий рівень відкритості економіки порівняно із іншими країнами, зокрема країнами СС, та світової економіки в цілому призвів до залежності у функціонуванні і розвитку вітчизняної економіки від кон'юнктури міжнародних ринків та вразливість до зміни зовнішніх чинників.

На рис. 1 можна побачити, що з 2007 р. до 2009 р. спостерігалося зростання обсягів експорту та імпорту товарів, але у кризовому 2009 р. відбувся суттєвий спад експортноімпортних операцій. Протягом наступних кількох років відбувалося зростання обсягів експорту та імпорту, але з 2013 р. можна побачити, що обсяги експорту та імпорту значно скоротилися. Це можна пояснити кількома причинами: по-перше, Держкомстат з 2014 p. тимчасово не враховує окуповану територію АР Крим та місто Севастополь, по-друге, існують різка девальвація гривні й ескалація військового конфлікту, по-третє, у 20142015 рр. знизилася ціна на світовому ринку на ключові для України сировинні товари (зернові, енергоносії, метали). В 2016 р. обсяг експорту зменшився порівняно з 2015 р. на $4,7 \%$, а імпорт знову почав перевищувати експорт, що дало негативне сальдо, а саме 2885 млн. дол. США.

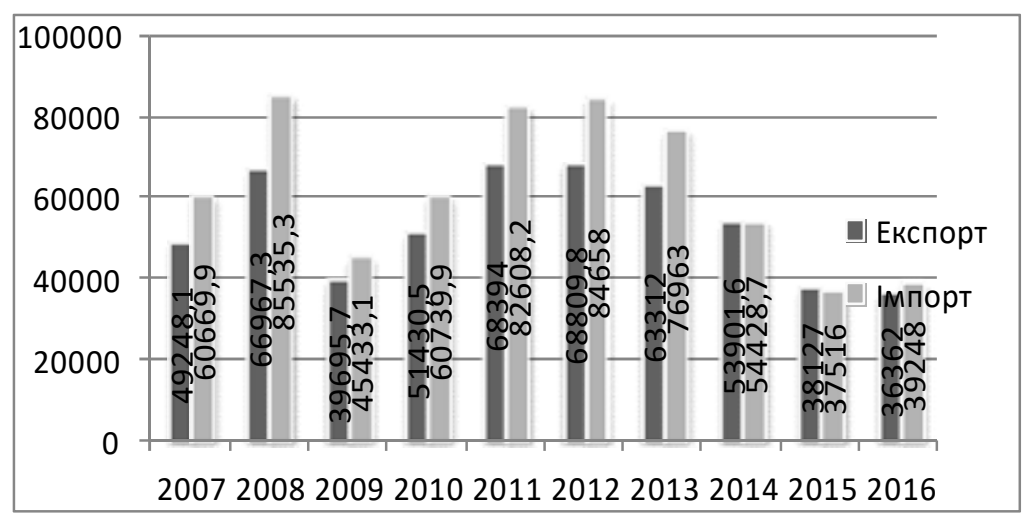

Рис. 1. Обсяги експорту та імпорту товарів у млн. дол. США за 2007-2016 рр. 


\section{Складено автором на основі даних [1]}

В умовах глобалізації існує загальна тенденція до збільшення відкритості національних економік. Орієнтація на зовнішні ринки є потужним стимулом розвитку національної економіки в умовах сприятливої зовнішньої кон'юнктури. Однак, коли зовнішній попит зменшується спад національної економіки може бути непропорційно великим.

Індикатор відкритості економіки або зовнішньоторговельна квота, що визначається як відношення сукупної вартості експорту та імпорту товарів і послуг, поділеної навпіл, до вартості ВВП, а також показує значимість зовнішньоторговельних зав'язків для країни, а не тільки експорту та імпорту.

Таблиця 1

Динаміка коефіцієнтів покриття експортом імпорту у 2007-2016 pp. [2]

\begin{tabular}{|c|c|c|c|c|c|c|c|c|c|c|}
\hline Показник & 2007 & 2008 & 2009 & 2010 & 2011 & 2012 & 2013 & 2014 & 2015 & 2016 \\
\hline $\begin{array}{l}\text { Рівень } \\
\text { відкритості } \\
\text { економіки }\end{array}$ & 47 & 51 & 48 & 52 & 57 & 55 & 51 & 66 & 41,7 & 51,9 \\
\hline $\begin{array}{l}\text { Рівень } \\
\text { експортної } \\
\text { залежності }\end{array}$ & 45 & 46,5 & 48,5 & 50 & 54,5 & 51 & 46,5 & 64,5 & 42,07 & 52,2 \\
\hline $\begin{array}{l}\text { Рівень } \\
\text { імпортної } \\
\text { залежності }\end{array}$ & 51 & 54,5 & 49 & 54 & 60 & 59 & 55,5 & 67 & 41,4 & 51,09 \\
\hline $\begin{array}{l}\text { Коефіцієнт } \\
\text { покриття } \\
\text { експортом } \\
\text { імпорту, } \\
\text { разів } \\
\end{array}$ & 0,81 & 0,78 & 0,87 & 0,85 & 0,82 & 0,81 & 0,82 & 0,99 & 1,01 & 1,03 \\
\hline $\begin{array}{l}\text { Стан } \\
\text { безпеки }\end{array}$ & 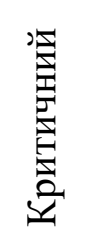 & 量 & 罳 & 量 & 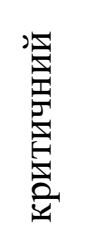 & 量 & 量 & 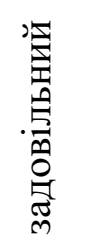 & 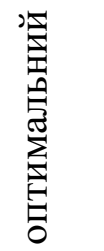 & 昜 \\
\hline
\end{tabular}

Результати розрахунку індикаторів відкритості економіки України свідчать про високий ступінь залежності від зовнішньої торгівлі та інших зовнішніх чинників, що впливають на стан зовнішньоекономічної безпеки. Різке підвищення показника відкритості економіки в 2014 р. перш за все пов'язано з підписанням Угоди про асоціацію з ЄС та воєнними діями на сході України. А також це можна пояснити тим, що саме в цьому році країна отримала значну кількість фінансової допомоги, а саме від МВФ, Світового банку, Європейського банку реконструкції та розвитку, а також від ряду країн Європейського Союзу, США, Канади, Японії та інших. Але з 2015 р. спостерігається помітне зменшення рівня відкритості економіки, а також рівнів експортної та імпортної залежності. Це можна пояснити тим, що у 2015-2016 рр. значно зменшились обсяги експортно-імпортних операцій, а рівень ВВП знизився на 31,3\% порівняно з 2014 р. Що стосується коефіцієнтів імпортної та експортної залежності, то показники експортної залежності показують, що український експорт недостатньо конкурентоспроможний, а це можна пояснити тим, що він переважно сировинний. Розрахунок коефіцієнта імпортної залежності показав, що зміна ії коливань аналогічна змінам коливань експортної. Це пояснюється тим, що приплив іноземної валюти за рахунок збільшення експорту дає змогу збільшити рівень імпортних угод. I навпаки, коли знижується рівень валютних надходжень, країна автоматично знижує імпортні угоди [3]. 
За наведеними даними в табл. 1 проаналізовано коефіцієнт покриття експортом імпорту у 2007-2016 рр. Виходячи з табл. 1, можна констатувати значне падіння цього показника у 2008 р., що пов'язано з економічною кризою. Ситуація почала покращуватися з 2014 р.

На сьогоднішній день Україна посіла 71-ше місце в рейтингу відкритості економік, оприлюдненому Всесвітнім економічним форумом.

Таким чином, можна констатувати, що обсяги експорту та імпорту значно скоротилися, розрахунок індикаторів відкритості економіки показав, що Україна надто залежна від зовнішньої торгівлі, що негативно впливає на стан зовнішньоекономічної безпеки, крім того, й інші індикатори мають негативні показники. Економіка України $є$ відкритою i характеризується значними обсягами експорту та імпорту. України має набагато вищий рівень відкритості економіки, якщо порівнювати із іншими країнами. Враховуючи незавершеність структурної перебудови економіки нашої країни та недостатній рівень розвитку внутрішнього ринку та ринкової інфраструктури, до проблеми підвищення відкритості економіки, слід підходити зважено і розсудливо [4, с.431]. 3 метою забезпечення економічного розвитку України слід розвивати не тільки зовнішньоторговельну складову відкритості економіки, а й фінансову, зокрема інвестиційну, технологічну та комунікаційну.

\section{Перелік використаних джерел:}

1. Офіційний сайт Державного комітету статистики України [Електронний pecypc]. - Режим доступу: http://www.ukrstat.gov.ua.

2. Щодо вдосконалення методології інтегрального оцінювання рівня економічної безпеки України: аналітична записка / [Ю. М. Харазішвілі, А. І. Сухоруков, Т. П. Крупельницька] // НІСД. - 2013 - Вересень. - [Електронний ресурс]. - Режим доступу : http://www.niss.gov.ua/articles/1358.

3. Архірейська Н. В. Сучасні проблеми забезпечення та оцінки рівня зовнішньоекономічної безпеки України / Н. В. Архірейська, Н. В. Панасенко // БізнесІнформ. - 2015 - № 1 - C. 40-45.

4. Koliada T. Evaluation of the State Intervention to the Country Economy by Global Democratic Markers / Tetiana Koliada, Ganna Muzychenko // Scientific Development and Achievements. - London: Sciemcee Publishing London, 2018. Vol. 1. - P. 421-433. 
Константюк Наталія

к.е.н., доцент

Тернопільський національний технічний університет імені Івана Пулюя

м. Тернопіль, Україна

Черенко Ірина

студентка групи ПФм-51

Тернопільський національний технічний університет імені Івана Пулюя,

м. Тернопіль, Україна

Konstantiuk Nataliia

Ph.D., Associate Professor

Ternopil Ivan Puluj National Technical University

Ternopil, Ukraine

Cherenko Iryna

student of group PFm-51

Ternopil Ivan Puluj National Technical University

Ternopil, Ukraine

\title{
ОЦІНКА ФІНАНСОВОГО СТАНУ ПІДПРИЕМСТВА ЯК НЕОБХІДНА СКЛАДОВА ПРИЙНЯТТЯ УПРАВЛІНСЬКИХ РІШЕНЬ ДЛЯ ЕФЕКТИВНОЇ ДІЯЛЬНОСТІ ПІДПРИЕМСТВА
}

\section{EVALUATION OF THE FINANCIAL SITUATION OF THE COMPANY AS THE NECESSARY COMPONENT OF MANAGEMENT DECISIONS FOR EFFICIENT ACTIVITY OF THE ENTERPRISE}

\begin{abstract}
Оцінка фінансового стану підприємства $\epsilon$ важливою складовою функцій управлінського персоналу щодо реалізації обраної стратегії бізнесу, забезпечення фінансової стійкості підприємства, а також займає вагоме місце в роботі зовнішніх аналітиків підприємства щодо оцінки інвестиційної привабливості та платоспроможності контрагентів, а також оцінки ділових партнерів в умовах ризику та невизначеності. На підставі оцінки фінансового стану управлінський персонал приймає рішення про напрями фінансування підприємства за рахунок власних джерел, інвестори - щодо формування портфеля цінних паперів, а кредитори визначають пріоритети щодо позик, які видають.

Правильна інтерпретація аналітичних показників, розрахованих на основі фінансової звітності, дозволяє управлінському персоналу та зовнішнім користувачам діагностувати проблеми, що наявні в діяльності підприємства, виявляти напрями діяльності, які вимагають додаткового фінансування для розвитку, ідентифікувати проблемні питання розподілу прибутку, як внутрішнього джерела фінансування розвитку підприємства. Відповідно, результати аналізу фінансового стану є основним інформаційним джерелом для розробки та прийняття управлінських рішень.

Найважливіше місце при оцінці фінансового стану належить аналізу фінансових результатів діяльності, оскільки саме фінансові результати вказують на ефективність діяльності того чи іншого підприємства. Будь-який суб'єкт господарювання, що діє у межах ринку, ставить собі за мету отримання прибутку. Для підприємства прибуток є показником, що створює стимул для інвестування в ті сфери, де можна домогтися найбільшого приросту вартості. Фінансові результати - прояв ефективності роботи суб'єкта підприємницької діяльності. У фінансовому результаті знаходить своє відображення прибуток або збиток від реалізації продукції, робіт, послуг, а також інших доходів і витрат. Прибуток синтезує в собі всі сторони діяльності підприємства, характеризує ефективність його господарської діяльності в цілому; це результат фінансово-господарської діяльності підприємства, та частина вартості продукту, що реалізується суб'єктом господарювання, яка залишається після покриття виробничих та інших, пов’язаних з виробництвом витрат.
\end{abstract}


Особливу увагу при оцінці фінансового стану підприємства також приділяють оцінці його фінансової стійкості. Фінансова стійкість є однією 3 найважливіших характеристик фінансового стану підприємства 3 позиції довгострокової перспективи. Вона відображає здатність підприємства відповідати за свої борги й зобов'язання та нарощувати економічний потенціал. Фінансова стійкість характеризує ступінь фінансової незалежності підприємства щодо володіння своїм майном і його використанням. Вона виступає головною умовою життєдіяльності і основою стабільності фінансового стану підприємства.

Фінансова стійкість є головним компонентом загальної стійкості підприємства, тому що є характерним індикатором на підприємстві перевищення доходів над витратами. Вона відбиває такий стан фінансових ресурсів, при якому підприємство, вільно маневруючи коштами здатне шляхом ефективного їх використання забезпечити безперебійний процес виробництва і реалізації продукції, а також витрати по його розширенню і відновленню. Предметом аналізу фінансової стійкості виступає власний фінансовий капітал та майно підприємства. Відповідно до такого визначення для оцінки фінансової стійкості підбираються показники, які характеризують стан і ефективність використання власного i позикового фінансового капіталу підприємства, його необоротних і оборотних активів. А індикаторами фінансової стійкості підприємства виступають надлишок власних обігових коштів та платоспроможність і кредитоспроможність. Фінансово стійким вважається таке підприємство, яке за рахунок власних коштів спроможне забезпечити запаси й витрати, не допустити невиправданої кредиторської заборгованості, своєчасно розрахуватись за своїми зобов'язаннями.

Фінансовий стан підприємства також залежить від результатів аналізу активів та пасивів, показників ліквідності, платоспроможності та ділової активності. Оцінка фінансового стану, включає в себе розгляд кожного показника, отриманого в результаті аналізу фінансового стану, з точки зору відповідності його фактичного рівня нормальному для даного підприємства рівню, ідентифікацію факторів, що вплинули на величину показника, визначення необхідної величини показника на перспективу та способів іiі досягнення.

В сучасних умовах господарювання своєчасна та об'єктивна оцінка фінансового стану підприємства набуває особливого значення, оскільки власники та інвестори не повинні нехтувати потенційними можливостями збільшення прибутку компанії, які можна виявити тільки на підставі своєчасного й об’ єктивного аналізу фінансового стану підприємств.

Саме тому оцінка фінансового стану є однією 3 найважливіших засад діяльності підприємств, яка надає інформацію стосовно того на якій стадії розвитку і діяльності знаходиться підприємство і які кроки необхідно здійснити для його подальшого процвітання. До кола питань, які вирішуються в результаті здійснення оцінки фінансового стану, відноситься також визначення можливих змін показників при зміні того чи іншого фактору, взаємозалежності показників фінансового стану та забезпечення цілеспрямованості їх системи для правильної орієнтації спеціалістів підприємства в методах поліпшення фінансового стану.

Отже, для підтримання стійкого фінансового стану слід систематично проводити його аналіз та оцінку 3 метою своєчасного виявлення та вжиття заходів щодо запобігання поширення негативних тенденцій у фінансовій діяльності підприємства.

\section{Перелік використаних джерел:}

1. Бас Ю. В. Теоретичні основи формування фінансової стратегії підприємства / Ю. В. Бас, Г. В. Зикова // Наука й економіка. - 2016. - № 1 (41). - С. 73-77.

2. Крамаренко Г. О. Фінансовий менеджмент: Підручник. / Г. О. Крамаренко, О. Є. Чорна. - Київ: Центр навчальної літератури, 2009. - 520 с.

3. Константюк Н. І. Теоретичні аспекти оцінки фінансової стійкості та іï місце в оцінці фінансового стану підприємства / Н. І. Константюк, М. Липна // Матеріали міжнародної науково-практичної конференції студентів і молодих учених «Соціальноекономічні аспекти розвитку економіки», 2017. - С.102-104. 
Константюк Наталія

кандидат економічних наук, доцент

Тернопільський національний технічний університет імені Івана Пулюя

м. Тернопіль, Україна

Konstantiuk Nataliia,

$\mathrm{PhD}$ in Economics Associate Professor

Ternopil Ivan Puluj National Technical University

Ternopil, Ukraine

\section{ВАЖЛИВІСТЬ ФІНАНСОВОГО ЗАБЕЗПЕЧЕННЯ ОСВІТИ ДЛЯ ЕКОНОМІЧНОГО ТА СОЦІАЛЬНОГО РОЗВИТКУ ДЕРЖАВИ \\ IMPORTANCE OF FINANCIAL SUPPORT OF EDUCATION FOR ECONOMIC AND SOCIAL DEVELOPMENT OF THE STATE}

Дослідження сучасних вчених різних країн все частіше підтверджують той факт, що найважливішим фактором розвитку національних та глобальних економічних систем сьогодні виступає людина та їі здібності, які формують інтелектуальний капітал. Останній, у свою чергу, формується під впливом освіти та у процесі здобуття знань індивідуумом. Слід підкреслити, що ООН використовує три основні критерії для оцінки рівня розвитку кожної країни: тривалість життя, рівень життя людей та валовий коефіцієнт охоплення вищою освітою. Освіта, перш за все вища, $є$ фундаментом та рушійною силою розвитку суспільства. Високий рівень освіти нації сприяє ефективності економічних і соціальних реформ, створює умови для прогресивної індивідуальної діяльності особистості. Освіта $\epsilon$ спільною передумовою економічного, соціального та політичного розвитку, єдиним правильним шляхом до демократії та соціальної справедливості. Таким чином, зміна усталеного суспільно-політичного суспільства, поліпшення економіко-соціальних умов стає можливим лише тоді, коли підвищується рівень освіти людей та їх усвідомлення. Саме тому в даний час завданням країни та основними векторами державної фінансової політики повинні стати належні інвестиції в освіту, що дозволить підготовку освіченої особистості, здатної забезпечити стабільність економічного розвитку держави.

Досвід розвинутих країн вказує на те, що економічне становище i добробут суспільства не можна поліпшити, скориставшись традиційними методами, використовуючи загальні види економічних ресурсів. Підтвердженням цього $\epsilon$ те, що деякі країни, незважаючи на глобальну економічну кризу, демонструють економічне зростання. Таким чином, економічне зростання у сучасних умовах господарювання стає можливим завдяки якісно новому типу капіталу, а саме людському капіталу у поєднанні з інтелектуальним капіталом.

Основою капіталу, що базується на знаннях, є людина, яка здатна набувати знання i застосовувати їх на практиці. Освіта має перш за все вплив на особистість як носій капіталу, що базується на знаннях. Тому створення капіталу, що базується на знаннях, можливе завдяки інвестиціям у освіту, результатом якого є наукові дослідження та інновації, які в сукупності знаходяться в центрі економіки, що базується на знаннях, і виступає базисним фактором довгострокового економічного зростання. Інвестиції в освіту, дослідження та інновації генерують капітал, який базується на знаннях, що сприяє ефективності та суперництву націй. Ця теза підтверджується витратами на вищу освіту, найбільш розвинуті країни світу здійснюють досить значні витрати фінансових ресурсів на вищу освіту, які розглядаються як стратегічні інвестиції в національну економіку країни. До першої десятки країн за розмірами видатків на освіту належать США, Швеція, Канада, Данія, Фінляндія, Швейцарія, Нідерланди, Великобританія, Автралія та Сінгапур. 
Отже, належне фінансове забезпечення освіти, і вищої зокрема, слід розглядати як інвестиції в економіку країни. Інвестиції в освіту завжди окуповуються і приносять довготривалий результат. Адже, саме ці країни, які найбільше витрачають на освіту, $\epsilon$ лідерами за обсягом ВВП у світі. Тобто, інвестиції в освіту є завжди виправданими та забезпечують високий економічний і соціальний розвиток.

\section{Перелік використаних джерел:}

1. Шапоренко О. Механізми державного регулювання фінансово-економічної діяльності вищих навчальних заладів / О. Шапоренко, Л. Паращенко // Вчені записки Університету «КРОК», - 2009. - № ((4) 52). - С. 140-147.

2. Konstantiuk, Nataliia. Higher Education as Important Investment project for State and Local Levels. Projekty lokalne i regionalne - interesariusze projektu. Prace Naukowe / Uniwersytet Ekonomiczny w Katowicach. - 2017. - p. 151-162.

УДК 334.788

Крутько Маргарита

кандидат економічних наук, доцент, Харківський національний технічний університет сільського господарства імені Петра Василенка Харків, Україна

Marharyta Krutko $\mathrm{PhD}$ in Economics Kharkiv Petro Vasylenko National Technical University of Agriculture, Kharkiv, Ukraine

\section{АКТИВІЗАЦІЯ РОЗВИТКУ АГРОПРОМИСЛОВОЇ ІНТЕГРАЦІЇ ACCRUING DEVELOPMENT OF AGRICULTURAL INTEGRATION}

Для посилення та стабілізації соціально-економічного середовища в нашій країні в умовах тих викликів, які диктує сьогодення, процес реорганізації об'єктів агропромислової сфери сприятиме збільшенню обсягу широкого спектру послуг, розширенню робочих місць, створенню комфортного середовища для функціонування різних форм господарювання на селі, підвищенню ефективності підприємницької діяльності, нарощенню капіталів та обсягів виробництва через утворення нових мультифункціональних структур господарювання в агробізнесі. Потребують детального вивчення та уточнення теоретичні і практичні питання шляхів посилення розвитку агропромислової інтеграції, через призму євроінтеграційного вектору розвитку, який обрала наша країна.

Досвід функціонування інтегрованих структур переконує, що одним із найважливіших чинників, які визначають умови розвитку інтеграції, безумовно, є інституціональні зміни. Існує тісний взаємозв'язок наявних інститутів 3 характером взаємодії суб'єктів господарювання. Зміни в інституціональному середовищі (приватизація і створення інституту приватної власності, у тому числі на землю; розширення сфери контрактних відносин; трансформація мислення, стереотипів поведінки та ін.) зумовили істотні зміни в інституціональній структурі АПК (розвиток багатоукладної економіки; формування інституту приватних посередників; розширення транзакційного сектору). Перетворення інституціонального середовища і структури АПК спричинило зміну самої суті традиційних форм міжгалузевих зв'язків, перетворивши їх на взаємовідносини власників; розширило різноманітність форм інтеграції; сприяло появі, разом з технологічними, великої кількості фінансово-економічних зв'язків [1, с. 54].

Проявився взаємозв'язок інтеграції та можливості вільного розпорядження ресурсами: придбання активів, основних засобів, акцій інших компаній; злиття і поглинання. 
Інтеграційні процеси характеризуються іншою якістю і здійснюються активніше в умовах, коли економічні суб'єкти мають господарську самостійність, право вільного укладання угод аж до відособлення і приєднання підприємств. Стан інституціонального середовища $є$ найважливішою макроекономічною умовою, яка впливає на можливість реалізації інтеграційних процесів [2, с. 385]. Н. Гладун визначає агропромислову інтеграцію як «розвиток виробничих i економічних зв'язків між галузями й підприємствами агропромислового комплексу, пов'язаних технологічно та орієнтованих на виробництво кінцевої продукції із сільськогосподарської сировини» [3, с. 55].

У перспективі розвиток інтеграційних процесів в аграрній сфері економіки здійснюватиметься під впливом вказаних чинників. Вони суттєво відрізняються за природою, силою і характером впливу. Проте їх дії властиві причинно-наслідковий зв'язок і синергія, цілеспрямоване управління ними може забезпечити підвищення ефективності реалізації інтеграційних відносин. Сукупний вплив цих чинників стосується виробничої, економічних i фінансової діяльності інтегрованого формування. Їх аналіз повинен проводитися не послідовно, а системно, завдяки чому забезпечується синергетичний ефект стійкого підвищення ефективності інтеграції [4, с. 85].

Агропромислова інтеграція $є$ важливим організаційно-господарським важелем, використання якого великою мірою визначає ефективність функціонування агропродовольчого комплексу. 3 метою подальшого розвитку інтеграційних процесів слід звернути увагу на: формування ефективної системи економічних відносин між учасниками інтеграційних формувань; удосконалення форм агропромислової інтеграції, земельних відносин та відносин власності; покращення інвестиційної привабливості й активізацію інвестиційної діяльності з метою розвитку виробництва і формування необхідного розміру оборотного капіталу, що забезпечує нормальне ведення виробничо-фінансової діяльності суб'єктів АПК - учасників інтеграційної взаємодії [5, с. 28$]$.

Суб'єкти інтеграційних перетворень є своєрідною еволюційно-організаційною формою співпраці людей, самобутня форма господарювання, діяльність якої грунтується на специфічних соціально-економічних та організаційно-суспільних принципах, що й надає рис самобутності і відрізняє від інших форм господарської діяльності. Одним з головних завдань у проведенні аграрних перетворень $є$ використання наукових, практичних, управлінських надбань та міжнародного і досвіду України попередніх періодів для уникнення помилок при проведенні сучасних кардинальних змін.

\section{Перелік використаних джерел:}

1. Лещева М. Г. Развитие интеграционных процессов в аграрной сфере экономики / М. Г. Лещева, В. И. Трухачев. - Ставрополь: АГРУС, 2008. - 308 с.

2. Лукінов I. I. Проблеми міжгосподарського кооперування і агропромислової інтеграції / I. І. Лукінов // Лукінов I. І. Вибрані праці: у 2 кн. Кн. 2. - К.: ННЦ IAЕ, 2007. - С. 385.

3. Гладун Н.В. Особливості поглиблення агропромислової інтеграції / Н. В. Гладун // Економіка АПК. - 2005. - № 12. - С. 55-58.

4. Басюркіна Н. Й. Особливості розвитку інтеграційних процесів в агропродовольчому секторі України / Н. Й. Басюркіна // Наукові праці НДФІ. - 2012. - № 3 (60). - С. 79-86.

5. Черевко Г. В. Інтеграційні процеси в АПК: перспективи залучення до них підприємств споживчої кооперації / Г. В. Черевко // Вісник Львівської комерційної академії. Серія економічна, 2015. - С. 24-29. 
Малинич Ганна

кандидат економічних наук

ст. викладач кафедри економіки та фінансів, Тернопільський національний технічний університет імені Івана Пулюя,

м. Тернопіль, Україна

Сливка Оксана

кандидат економічних наук доцент кафедри управління персоналом та економіки праці ПрАТ «ВНЗ «Міжрегіональна Академія управління персоналом» м. Київ, Україна Malynych Hanna PhD (Economics), Ternopil Ivan Puluj National Technical University Ternopil, Ukraine

Slyvka Oksana

$\mathrm{PhD}$ (Economics), Interregional Academy of Personnel Management Kyiv, Ukraine

\section{НАВИКИ ТА КОМПЕТЕНЦІЇ ПРАЦІВНИКА У ХХІ СТОЛІТТІ ПОГЛЯД РОБОТОДАВЦЯ \\ SKILLS AND COMPETENCIES OF A WORKER IN THE XXI CENTURY: AN EMPLOYER'S VIEW}

Глобалізація економіко-суспільних процесів та підвищення рівня інформатизації суспільства визначає доцільність перегляду компетенцій та навичок працівників. Актуалізується проблема подолання розбалансованості між компетенціями випускників вищої школи та вимогами роботодавців. Науковий пошук моделей «ефективного працівника» в сучасних умовах стосуються покоління Y i Z.

Покоління Y (у наукових дослідженнях зустрічаємо the Millennials, Generation Why, The Generation Next, The Generation Zero, Network kids) формувалося під впливом глобалізації, цифрових технологій та комунікаційних технологій, характеризується міцністю сімейних зв’язків, можливістю вибору особистого розвитку, культурного різноманіття на формування його цінностей. Це покоління відрізняється від попередніх установками щодо особливих вимог до робочого місця та можливості їх кар'єрного просування. Представники цього покоління зосереджуються на отриманні швидких результатів діяльності; можливості власної реалізації; комфортності на робочому місці; гнучких формах зайнятості; підтримки неформального стилю не лише у спілкуванні, а й у робочому середовищі; вважають розважальний компонент складовою будь-якої діяльності [1].

Сьогодні відбувається становлення покоління Z (покоління M, Internet Generation, «Generation M (multitasking»), «Homelanders»). Період їх народження можна характеризувати нестабільністю економічних, соціальних, політичних систем, порушенням світового порядку, збільшення випадків тероризму, зміни клімату, поширення насильства. Покоління Z відрізняється від інших більшими проявами нетерпимості та можливості виконувати та вирішувати одночасну декілька завдань, тобто багатозадачністю. Це покоління не уявляє свого життя без інформаційних та цифрових технологій, за їх допомогою формується їх світ та цінності, що деколи може бути загрозою для їх життя, адже вони живуть у власній реальності. Воно надає перевагу віртуальному спілкуванню, індивідуальному навчанню 3 використанням інформаційних технологій, вони обізнані у різних галузях, оскільки 
отримують знання із мережі Інтернет, надають перевагу візуалізації та коротким простим текстам інтерактивного змісту. Основною проблемою покоління $\mathrm{Z}$ у майбутньому є низький рівень емоційного інтелекту, тобто здатністю ідентифікувати і управляти власними емоціями і сприймати емоції інших людей.

За результатами досліджень [2] працівник з точки зору роботодавця повинен володіти такими навиками: критичне мислення і вирішення завдань (Critical Thinking and Problem Solving); співпраця (Collaboration Across Networks and Leading by Influence); адаптивність (Agility and Adaptability); ініціатива і підприємливість (Initiative and Entrepreneurship); оцінка і аналіз інформації (Assessing and Analyzing Information); уява та зацікавленість (Curiosity and Imagination), ефективне усне та письмове спілкування (Effective Oral and Written Communication) [2], що у своїй сукупності становлять м'які навики. У сучасних умовах так звані тверді навики (hard skills), тобто прямі професійні, відходять на нижчий щабель, що засвідчують результати і інших проведених досліджень [3]. У The Future of Jobs Report 2018 зазначено, що динамічні зміни у структурі та змісті професій майбутнього потребуватимуть формування м'яких навиків у працівників.

Досягнення балансу задоволення потреб між суб’єктами «працівник-роботодавець» вимагає здійснення подальших досліджень щодо ідентифікації можливостей отримання відповідних навиків та компетенцій в закладах освіти.

\section{Перелік використаних джерел:}

1. Robinson M. T. The Generations - Which Generation are You? // Career Planner.com. URL: http://www.careerplanner.com/ Career-Articles/Generations.cfm

2. Wagner T. The Global Achievement Gap: Why Even Our Best Schools Don't Teach the New Survival Skills Our Children Need - And What We Can Do About It. - Basic Books, 2008.

3. Archer W., Davison J. Graduate Employability: What do employers think and want? The Council for Industry and Higher Education, 2008. http://www.brunel.ac.uk/services/pcc/staff/employability/?a $=92718$ кафедри економічного аналізу та обліку,

Національний технічний університет «Харківський політехнічний інститут»,

м. Харків, УкраїнаMardus Nataliya Candidate of Sciences (Economics), associate professor, assistant professor of the Department of Economic Analysis and Accounting,

National Technical University "Kharkiv Polytechnic Institute", Kharkov, Ukraine

\section{ПРОГНОЗУВАННЯ ЗАБЕЗПЕЧЕННЯ РОЗВИТКУ ВНУТРІШНЬОГО РИНКУ ТОВАРІВ \\ FORECASTING THE PROMOTION OF DEVELOPMENT OF THE INTERNAL MARKET OF GOODS}

Прогнозування змін коефіцієнтів розвитку створює підгрунтя для того, щоб визначити значення узагальнюючих індикаторів стану та інтегральний індикатор внутрішнього ринку товарів в прогнозному періоді при різних сценаріях. 
Невизначеність прогнозної ситуації, що отримана зв попередніми результатами дослідження, викликає необхідність до вдосконалення забезпечення розвитку внутрішнього ринку товарів. Для вирішення цього питання пропонується дескриптивна модель забезпечення розвитку внутрішнього ринку товарів, яка відображає етапи забезпечення розвитку внутрішнього ринку товарів з притаманними їм методами та результатами, що можуть бути досягнуті завдяки їх виконанню.

Першим етапом $\epsilon$ формування інформаційної бази забезпечення розвитку внутрішнього ринку товарів, що містить дані стосовно статичних та динамічних показників, що характеризують внутрішній ринок товарів. Для виконання цього етапу використовуються методи збору, розрахунку та аналітичної обробки даних. Результатом даного етапу $\epsilon$ сформована інформаційна база дослідження внутрішнього ринку товарів, з використанням якої може бути здійснена оцінка стану та розвитку внутрішнього ринку товарів.

Наступним етапом є статичне оцінювання, в рамках якого дається оцінка стану внутрішнього ринку товарів. 3 цією метою використовуються методи систематизації, ідентифікації, нормування, агрегування та побудови шкали (з рівними інтервалами). На цьому етапі визначаються індикатори стану внутрішнього ринку товарів та надається їх інтерпретація.

Третім етапом є динамічне оцінювання, яке грунтується на використанні методів міжсистемної відповідності, індексів, агрегування, побудови номінальної шкали. В результаті виконання цього етапу визначаються значення індикаторів розвитку внутрішнього ринку товарів.

Наступним є етап оцінювання зовнішніх факторів, що можуть чинити вплив на розвиток внутрішнього ринку товарів. Виконання цього етапу передбачає використання комплексу методів, серед яких СТЕП-аналіз, індексний, варіаційний, кореляційний, сценарний, матричний аналіз та аналіз ризикованості. Як результат реалізації даного етапу визначається пріоритетність зовнішніх факторів впливу на розвиток внутрішнього ринку товарів.

Наступним етапом є розробка прогнозу розвитку внутрішнього ринку товарів, яка грунтується на використання методів економіко-математичного програмування та сценарного аналізу. Завдяки виконанню даного підходу можуть бути визначені прогнозовані зміни коефіцієнтів розвитку внутрішнього ринку товарів.

На основі результатів прогнозування повинна розроблятися та реалізовуватися стратегія забезпечення розвитку внутрішнього ринку товарів, яка грунтується на використанні методів стратегічного орієнтування та управління. Результатам цього етапу забезпечення є зміна показників стану та розвитку внутрішнього ринку товарів.

Слід зазначити, що результати, отримані на останньому етапі забезпечення, з одного боку, $є$ його кінцевим підсумком за певний період, а з іншого дає поштовх для нового витка забезпечення, адже, щоб усвідомити зміни, що відбулися має бути сформована відповідна інформаційна база, на основі якої проведене статичне та динамічне оцінювання, та виконані наступні етапи забезпечення.

Таким чином, модель забезпечення розвитку внутрішнього ринку товарів відбиває його сутність як багато-ітераційного процесу, що складається з послідовно здійснюваних етапів, кінцевою метою яких $\epsilon$ досягнення запланованої зміни коефіцієнтів розвитку внутрішнього ринку товарів, що дасть змогу покращити його стан.

Складність процесу забезпечення розвитку внутрішнього ринку товарів потребує відповідної структуризації забезпечення, базуючись на якій у сукупності з дескриптивною моделлю забезпечення доцільна розробка методичного підходу до забезпечення розвитку внутрішнього ринку товарів, що включає формування бази та системи забезпечення, а також розробка та реалізація стратегії забезпечення розвитку внутрішнього ринку товарів. Вибір того чи іншого виду стратегії дає можливість на основі визначення показників стратегічного орієнтування за векторами розвитку прийняти обгрунтоване рішення щодо визначення 
стратегічних ініціатив та встановлення стратегічних пріоритетів, реалізація яких дозволить досягти поставлених цілей забезпечення.

\section{Перелік використаних джерел:}

1. Бобровська О. Ю. Еволюція прогнозування розвитку соціально-економічних процесів: стан i напрямок удосконалення. URL: http://www.dridu.dp.ua/zbirnik/201102(6)/11boysnu.pdf (дата звернення: 13.02.2019).

2. Жилінська Л. О.Характеристика методів прогнозування показників діяльності підприємства. Інвестиції: практика та досвід. 2009. № 1. С.42 - 44.

3 Холден К., Піл Д. А. Томпсон Дж. Л. Економічне прогнозування: вступ. Київ: ЕМЦ, 1996. $216 \mathrm{c}$.

4. Уманців Ю. М. Катран М. В. Розвиток внутрішнього ринку споживчих товарів в Україні. Бізнес Інформ. 2017. №8. С. 271-275.

5. Мардус Н. Ю. Методологічний базис забезпечення внутрішнього ринку товарів. Економічний форум, 2/2018. Луцьк. 2018. С. 33-38.

6. Мардус Н. Ю. Формування основних компонентів бази забезпечення розвитку внутрішнього ринку товарів. Інноваційна економіка. 2018. С. 36-40.

Маркович Ірина кандидат економічних наук, доцент доцент кафедри економіки та фінансів Тернопільський національний технічний університет імені Івана Пулюя м. Тернопіль, Україна

Iryna Markovych $\mathrm{PhD}$ (Economics) Docent, Assosiate Professor of Economics and Finance Department Ternopil Ivan Puluj National Technical University Ternopil, Ukraine

\section{ПОЛІЦЕТРИЧНИЙ РОЗВИТОК РЕГІОНІВ В КОНТЕКСТІ ПРОЦЕСІВ ДЕЦЕНТРАЛІЗАЦЇ̈ \\ POLICENTRIC DEVELOPMENT OF REGIONS IN THE CONTEXT OF DECENTRALIZATION PROCESSES}

Об єктивне оцінювання функціонування територіально-господарських утворень дає змогу точно ідентифікувати можливі джерела зростання та загрози, які не дозволяють їм розвиватися із найвищим рівнем ефективності.

У дослідженні Ж. Веделя [1, с. 392] вказується, що децентралізація полягає у передаванні владних повноважень не державним службовцям і органам, що представляють центральну владу, а іншим органам, що не знаходяться в ієрархічному підпорядкуванні останній, переважно, які обрані населенням.

Стратегічний підхід до планування розвитку територіально-господарських утворень усіх рівнів вимагає повного узгодження їхніх цілей, врахування інтересів та потенціалів суб'єктів, сценарне планування на основі розробки декількох варіантів зовнішніх та внутрішніх змін, гнучкість у використовуваних інструментах реалізації, відкритість та публічність.

Доволі сильним обмеженням у процесах реалізації стратегій є їхня «відірваність» від операційного рівня та процедур, тобто стратегічні цілі не мають своїм продовженням розробку конкретних дієвих механізмів їх впровадження проектного характеру, орієнтацію 
на вимірювальні результати і т.д. Це є неприпустимою вадою стратегічних документів багатьох територіально-господарських утворень.

Розглядаючи рівень ОТГ варто зосередитися на аналізі таких 4 показників, які характеризують фінансові аспекти функціонування територіальних громад:

1. Власні доходи на одного мешканця (співвідношення обсягу надходжень власних доходів до кількості мешканців відповідної ОТГ);

2. Динаміка надходжень місцевих податків i зборів у поточному періоді порівняно із аналогічним показником попереднього року;

3. Рівень дотаційності бюджетів (співвідношення обсягу базової чи реверсної дотації до загальної суми доходів ОТГ без урахування субвенцій з державного бюджету);

4. Питома вага видатків на утримання апарату управління у фінансових ресурсах ОТГ (питома вага видатків на утримання апарату управління органів місцевого самоврядування в сумі власних доходів загального фонду).

Відповідно до Методики формування спроможних територіальних громад, затвердженої постановою Кабінету Міністрів України від 08.04.2015 № 214 «Про затвердження Методики формування спроможних територіальних громад», спроможні територіальні громади - територіальні громади сіл (селищ, міст), які в результаті добровільного об'єднання здатні самостійно або через відповідні органи місцевого самоврядування забезпечити належний рівень надання послуг, зокрема у сфері освіти, культури, охорони здоров'я, соціального захисту, житлово-комунального господарства, 3 урахуванням кадрових ресурсів, фінансового забезпечення та розвитку інфраструктури відповідної адміністративно територіальної одиниці.

На прикладі Тернопільської області можна відстежити поліцентричний розвиток національної економіки, тобто очевидною $\epsilon$ нерівномірність досягнутих результатів та фінансово-економічних потенціалів.

За підсумками І-го півріччя 2018 року середній показник надходжень власних доходів на 1-го мешканця по 40-ка ОТГ області збільшився на 332,8 грн (+45,0 \%) та склав 1155,3 грн (у тому числі: по 36-ти ОТГ, утворених у 2015-2016 роках цей показник зріс на 29,2 \% та становить 1152,6 грн, а по 4-х утворених у 2017 році - у 3 рази і становить 1171,6 грн).

Щодо динаміки надходжень місцевих податків зборів за І-ше півріччя 2018 року порівняно з І-м півріччям 2017 року, то найвищий темп зростання цих надходжень спостерігається по бюджету Скориківської ОТГ (+78,9\%), найнижчий рівень - по Лановецькій ОТГ, де надходження зменшилися на 2,5\%. Серед ОТГ області 36 громад отримують 3 державного бюджету базову дотацію, 2 перераховують реверсну дотацію.

Найвищий рівень дотаційності у Колиндянській громаді, у якої обсяг базової дотації у загальній сумі доходів становить 50,1\%. Найбільша питома вага видатків на утримання апарату управління у власних ресурсах ОТГ (без урахування трансфертів) припадає на бюджет Лопушненської ОТГ - 82,9 \%, найменша - на бюджет Теребовлянської ОТГ - 14,2 \% [2].

Така нерівномірність в розподілі доходів та перерахувань з бюджетів верхнього рівня свідчить про незбалансованість розвитку та потребі активізувати потенціал в громадах, які залишаються фактично «на утриманні» інших громад.

\section{Перелік використаних джерел:}

1. Ведель Ж. Административное право Франции / Ведель Ж.; [пер. с франц. Л. М. Энтина]. - М. Прогресс, 1973. - 512 с.

2. Експерти проаналізували бюджети об'єднаних громад кожної області [Електронний ресурс]. - Режим доступу: https://decentralization.gov.ua/news/9724 
УДК 336:352

Подвірна Тетяна

кандидат економічних наук, старший викладач Тернопільський національний технічний університет ім. І. Пулюя

м. Тернопіль, Україна

Tetiana Podvirna

$\mathrm{PhD}$ in Economics, Senior Lecturer

Ternopil Ivan Puluj National Technical University

Ternopil, Ukraine

\section{ОСОБЛИВОСТІ ФІНАНСУВАННЯ ОБ'ЄДНАНИХ ТЕРИТОРІАЛЬНИХ ГРОМАД ДЕРЖАВНИМ БЮДЖЕТОМ \\ FEATURES OF FINANCING OF THE UNITED TERRITORIAL COMMUNITIES BY THE STATE BUDGET}

Однією 3 найбільш визначальних реформ 3 часів української незалежності децентралізація місцевого самоврядування. Вона охопила різні сфери: освіта, охорона здоров'я, містобудування, державна реєстрація, надання адміністративних послуг, соціальна сфера, сфера земельних відносин та ін. Метою реформи місцевого самоврядування $\epsilon$, передусім, забезпечення його фінансова спроможності самостійно, за рахунок власних ресурсів, вирішувати питання місцевого значення.

В урядовій методиці формування спроможних громад роз'яснено термін «спроможна територіальна громада» - це територіальні громади сіл (селищ, міст), які у наслідок добровільного з'єднання можуть самостійно вирішувати питання та задовільняти повноваження які виникають перед утвореною громадою за рахунок власних кадрових ресурсів, фінансового забезпечення та розвитку інфраструктури даної адміністративнотериторіальною одиницею [4].

Органам місцевого самоврядування передали додаткові бюджетні повноваження та стабільні джерела доходів для їх реалізації, стимулювання територіальних громад до об'єднання та переходу на прямі міжбюджетні відносини 3 державним бюджетом 3 відповідним ресурсним забезпеченням на рівні міст обласного значення, запровадження правових засад формування спроможних територіальних громад шляхом підвищення їх фінансової та економічної спроможності тощо.

Для того щоб будувати та ремонтувати дороги, школи, амбулаторії, стадіони, ЦНАПи (Центри надання адміністративних послуг) тощо потрібні великі кошти яких у місцевих бюджетах - особливо у сільській місцевості обмаль. Тому щороку з державного бюджету через механізми субвенцій і проектного фінансування в територіальні громади виділяють фінансовий ресурс для підтримання соціально-економічного розвитку. I хоча суми становлять менше 10 \% загального обсягу коштів, переданих з державного бюджету до місцевих, для окремих територіальних громад вони є чи не єдиним джерелом фінансування свого розвитку.

Трансферти - кошти, одержані від інших органів державної влади, органів місцевого самоврядування, інших держав або міжнародних організацій на безоплатній та безповоротній основі.

Основні види трансфертів які входять до бюджетів ОТГ:

- базова, стабілізаційна та додаткова дотація 3 державного бюджету місцевим на здійснення переданих державою видатків на утримання закладів освіти та охорони здоров'я; 
- субвенції з державного бюджету місцевим: на здійснення заходів щодо соціальноекономічного розвитку окремих територій; на надання державної підтримки особам 3 особливими освітніми потребами; на проведення виборів депутатів місцевих рад та сільських, селищних, міських голів; на формування інфраструктури об'єднаних територіальних громад; на освітню та медичну субвенції [1].

Субвенцію спрямовану на розвиток системи охорони здоров'я у сільській місцевості загалом має бути скеровано 5 млрд. грн. (4 з яких було виділено ще 2017 р.)., а у 2019 року, як і 2018-го, на неї виділено по 1 млрд. грн. На сьогодніший день на різних стадіях реалізації перебувають 517 проектів нового будівництва амбулаторій первинної медичної допомоги у всіх регіонах України.

Субвенцію на формування інфраструктури у 2019 році скеровують лише до бюджетів об'єднаних територіальних громад, а обласні, районні та міські бюджети її не отримують. Кожна ОТГ отримає частку субвенції, виходячи зі своєї площі та чисельності сільського населення.

Призначення субвенції доволі широке: від поліпшення якості надання адміністративних послуг до будівництва та ремонту вулиць, доріг і мостів. На цю субвенцю у 2019 році в бюджеті України заклали 2,1 млрд. грн, що на 200 млн.грн. більше ніж у 2018 році.

Сфера використання коштів субвенції на здійснення заходів щодо соціальноекономічного розвитку окремих територій чимала: від придбання обладнання для бібліотек і клубів, здійснення екологічних і природоохоронних заходів до будівництва і ремонту будинків і доріг комунальної власності. Обсяг субвенції, закладений на 2019 рік, практично не змінився порівняно 3 попереднім роком і становитиме 4,9 млрд. грн.

У 2012 році був спеціально створено Державний фонд регіонального розвитку (ДФРР) через який держава фінансує проекти, скеровані на розвиток регіонів. У 2019 року обсяг ДФРР становитиме 7,7 млрд. грн. проти 6 млрд. грн 2018 р. [2]. Відповідно до Бюджетного кодексу України його обсяг мав би становити 9,2 млрд грн. Тобто найпрогресивніший з усіх механізмів державної фінансової підтримки розвитку регіонів державою недофінансовано.

Субвенція на фінансове забезпечення будівництва, реконструкції, ремонту та утримання автомобільних доріг загального користування місцевого значення, вулиць і доріг комунальної власності у населених пунктах у 2019 року збільшили на 28 \%, порівняно 3 2018 роком, до 14,7 млрд. грн. Основне призначення цієї субвенції - ремонт і будівництво доріг. Фінансування відбувається через Державний дорожній фонд, який створено у складі спеціального фонду державного бюджету.

Сумарно на підтримку розвитку територіальних громад за рахунок державного бюджету передбачено понад 30 млрд. грн., а у 2018 р. на державну субвенцію було виділено 25,4 млрд. грн.

Отже, 3 державного держбюджету ОТГ напряму отримують гроші на освіту, медицину, спорт, культуру, соціальний захист. Ще за державні гроші можуть реалізовувати власні проекти. Чим активніше громада, тим більше проектів буде реалізовано. Відповідно ОТГ може більше заробляти і більше витрачатиме на розвиток територій, що в подальшому призведе до покращення рівня життя людей.

\section{Перелік використаних джерел:}

1. Джерела доходів мають місцеві бюджети у 2019 році [Електронний ресурс]. - Режим доступу: https://storage.decentralization.gov.ua/uploads/library/file/369/2019.pdf

2. Моніторинг процесу децентралізації влади та реформування місцевого самоврядування [Електронний ресурс]. - Режим доступу: https://storage.decentralization.gov.ua/uploads/library/file/389/10.03.2019.pdf

3. Фінансова децентралізація: результати 2018 року та перспективи 2019 року [Електронний ресурс]. - Режим доступу: https://storage.decentralization.gov.ua/uploads/library/file/382/Fourpager.pdf 
4. Формування спроможних територіальних громад. Практичний посібник / Сайт Асоціації міст України [Електронний ресурс] - Режим доступу: https://www.auc.org.ua/sites/default/files/library/otgbook3new_obgortka_i_blok.pdf

\title{
СЕКЦІЯ 2. \\ ОСОБЛИВОСТІ ІНТЕГРАЦІЇ ДЕРЖАВИ, БІЗНЕСУ, НАУКИ, ОСВІТИ В УМОВАХ ЦИФРОВІЗАЦІЇ СУСПІЛЬСТВА
}

\author{
Iryna Kramar \\ Associate Professor, PhD \\ Ternopil Ivan Puluj National Technical University, Ternopil, Ukraine \\ UNIVERSITY-INDUSTRY COLLABORATION
}

"Building collaborative relationships with universities...is by far the best way to ensure they are responding to industry needs" - Lord Mandelson

Collaboration with universities is an important innovation strategy for enterprises. Today the need for innovation in business environment intensify the trend of university-industry collaboration. Although it's a trend now, but it has a long tradition in several countries worldwide [1]. It is crucial to understand that universities play a significant role in achieving economic growth in today's knowledge-based societies [2].

Therefore one of the main tools to achieve economic growth in Ukraine is the rapid development of small entrepreneurship in science, especially in university environment. There are different forms of such collaboration between universities and industries, for example scientific and technological parks, business incubators etc. The world experience of the creation and development of scientific and technological parks shows that sufficient effect can be obtained only if the university infrastructure is involved in the current process. In this case it provides a continuous human resources policy and actively engages youth as the most dynamic part of the society.

Scientific and technological parks provide a unique opportunity to launch an effective innovation process. The purpose of such park is to promote and commercialize intellectual R\&D and technological projects in the field of theoretical and applied sciences. That is why it is important to organize activities aimed at development and improvement of relations between universities and industries (i.e. trainings, meetings, workshops etc.). The target audience of scientific and technological parks is active, creative youth with entrepreneurial mind set, scientists and graduates interested in creating their own start-ups and introducing innovations.

Main tasks of the scientific and technological parks are:

- to improve conditions for interaction between universities and industries;

- to facilitate the implementation of managerial and creative potential of young scientists and students;

- to develop the infrastructure of youth entrepreneurship support;

- to help youth in implementing their business ideas through educational, methodological and informational training etc.

The collaboration between universities and SMEs (small and medium enterprises) should be based on a small projects base. These projects must focus on localized and specific problematic areas in the industrial companies, where the potential of improvement and innovation is large and propose new and efficient solutions supported by technical/scientific methodologies. The involvement of managers and collaborators of SME companies and the clearly definition of their 
roles in the project are fundamental issues for the collaboration success. Often scientific and technological parks aim to work on business projects which solve most relevant issues in various fields with the help of IT development and innovative approaches, claiming success at the market.

The collaboration between universities and the industry is increasingly perceived as a vehicle to enhance innovation through knowledge exchange. This is evident by a significant increase in studies that investigate the topic from different perspectives. However, this body of knowledge is still described as fragmented and lacks efficient comprehensive view. To address this gap, we employed a systematic procedure to review the literature on universities - industry collaboration

The collaboration between universities and the industry is increasingly perceived as a vehicle to enhance innovation through knowledge exchange. This is evident by a significant increase in studies that investigate the topic from different perspectives. However, this body of knowledge is still described as fragmented and lacks efficient comprehensive view. To address this gap, we employed a systematic procedure to review the literature on universities - industry collaboration

The collaboration between universities and the industry is increasingly perceived as a vehicle to enhance innovation through knowledge exchange. This is evident by a significant increase in studies that investigate the topic from different perspectives. However, this body of knowledge is still described as fragmented and lacks efficient comprehensive view. To address this gap, we employed a systematic procedure to review the literature on universities - industry collaboration

The collaboration between universities and the industry is increasingly perceived as a vehicle to enhance innovation through knowledge exchange. This is evident by a significant increase in studies that investigate the topic from different perspectives. However, this body of knowledge is still described as fragmented and lacks efficient comprehensive view. To address this gap, we employed a systematic procedure to review the literature on universities - industry collaboration

The collaboration between universities and the industry is increasingly perceived as a vehicle to enhance innovation through knowledge exchange. This is evident by a significant increase in studies that investigate the topic from different perspectives. However, this body of knowledge is still described as fragmented and lacks efficient comprehensive view. To address this gap, we employed a systematic procedure to review the literature on universities-industry collaboration

In conclusion, the collaboration between universities and industries is increasingly perceived as a vehicle to enhance innovation through knowledge exchange. Formation of the market economy in Ukraine actualized the activities of higher educational establishments in the field of commercialization the results of R\&D. Such tendency should support the innovative development of the country and therefore its economic growth.

\section{References:}

1. Ankrah S, AL-Tabbaa O. Universities-industry collaboration: a systematic review / S. Ankrah, O. AL-Tabbaa // Scand J Manag 31:387, 2015 - 408 p.

2. Pinheiro R., Langa PV, Pausits A. One and two equals three? The third mission of higher education institutions / R. Pinheiro, PV Langa, A. Pausits // Eur J High Educ 5:233, 2015 - 249 p. 
Pululu Yonda Heritier

Student of group IBM-22

Ternopil Ivan Puluj National Technical University

Ternopil, Ukraine

Scientific supervisor: Iryna Kramar

$\mathrm{PhD}$, Associate Professor

Ternopil Ivan Puluj National Technical University

Ternopil, Ukraine

\section{DIGITAZATION IN DIFFERENT AREAS OF LIFE}

The evolution of current world more specifically technological development, brings changes in people daily lives. Nowadays, our lives are much technologically dependent than ever before: phone, computers, television, cars, etc. This point out that being technologically updated nowadays is important. One of the current trends in different fields in the area of technologies is digitization. Although it has both positive and negative impact on our lives, in this paper the attention is paid to the benefits of its use.

By definition, "digitization is the process of conversion of text, pictures, or sound into a digital form that can be processed by a computer" [1]. Digitization makes all information available and accessible in a digital format. Digitized information helps to facilitate archiving and sharing, gives access to the information which was earlier impossible to get. For example: an original historical document can only be used by people who physically go to the places where it is kept; but if it is digitized it becomes accessible worldwide; more and more historical and cultural documents are being digitized for purposes of archiving and sharing.

Another benefit of information digitization is information storage; for example: before computers were invented, all documents were archived in papers, and in case of fire, all the information contained in these documents would be lost, while with the use of digitization of data, there is a good chance of recovering data (i.e. ICloud where images or documents are saved, and even in case of losing a computer or mobile, a person is still able to find all the data once he/she gets internet connection on another device.

In business, years ago, business processes were analog but today digitization is widely used. It brings a strong help to entrepreneurs, enabling to detect potential customers worldwide without making a move; helps bank or store to use worldwide payment; makes online advertisement; helps business due to its fastness; facilitates communication between two businesses or between business and customers etc.

In science, digitization has brought tremendous solutions; for example, medicine: to determine paternity or maternity of somebody by deoxyribonucleic acid (DNA) analysis; to detect the smallest microbes that may exist on making examination by using electron microscope etc.

In education, digitization allows students and teachers to stay well informed about the latest information as well as helps in quick research etc.

Hence, thanks to digitization data is easily accessible for use across various platforms, devices, interfaces. As in different areas of lives, people are faced with digitization and so to continue professional growth and development they must stay updated to technological innovations.

\footnotetext{
References:

1. https://en.oxforddictionaries.com/definition/digitization
} 
кандидат економічних наук, доцент доцент кафедри економіки та фінансів

Тернопільський національний технічний університет імені Івана Пулюя

Dyachun Olga

$\mathrm{PhD}$ (Economics)

Docent, Assosiate Professor of Economics and Finance Department

Ternopil Ivan Puluj National Technical University

\title{
ЧИННИКИ, ЩО ВПЛИВАЮТЬ НА ФОРМУВАННЯ СИСТЕМИ ЗБУТУ ПРОДУКЦІЇ ПІДПРИЕМСТВ \\ FACTORS INFLUENCING THE FORMATION OF THE SALES SYSTEM OF ENTERPRISES
}

\begin{abstract}
Важливість побудови раціональної системи збуту та правильного вибору збутової політики підприємства є безумовною з огляду на забезпечення нею доведення товару від виробника до споживача, що логічно довершує інші маркетингові заходи, дозволяє отримати й оцінити фінансову віддачу від здійснених маркетингових зусиль. Правильне формування системи збуту безпосередньо залежить від розуміння менеджерами основних чинників, що впливають на неї. Науковці, спеціалісти-економісти виділяють різноманітні групи чинників, які на макрота мікроекономічних рівнях впливають на формування системи збуту на підприємстві та іiі ефективність. Зокрема, Чмихало Н. В., Оккерт І. Л., Ольховська А. Б., Сотнікова Н. В. класифікують чинники впливу на збутову систему та політику: за сферою, за характером та за тривалістю впливу 4, с. 126]. За сферою впливу виділяють зовнішні (на рівні діяльності підприємства, галузі, регіону), базові (визначають організацію системи збуту на макро- та мікроекономічному рівнях та іiі ефективність), доповнюючі (коригують елементи збутової системи, підвищують іï ефективність) та внутрішні (на рівні підприємства, структурного підрозділу, робочого місця) чинники.
\end{abstract}

За тривалістю впливу вони можуть бути постійними та тимчасовими.

За характером впливу виділяють:

-економіко-фінансові (тип економіки; ступінь загальної макро-економічної ситуації в державі; стан розвитку економіки країни, який включає стан розвитку виробництва, рівень інфляції, стан грошового обігу і надійність національної грошової одиниці, рівень стабільності економічної кон'юнктури і ємність товарного ринку, рівень монополізму у виробництві та у сфері реалізації, конкурентоспроможність продукції; фінансовий стан підприємств; систему розрахунків між партнерами та їі стан; систему оподаткування, фінансування, кредитування, страхування та аудиту);

-організаційно-правові (стан розвитку інфраструктури, що забезпечує здійснення збутової діяльності підприємствами на внутрішньому та зовнішньому ринках; стан розвитку служб збуту та маркетингу, які безпосередньо забезпечують здійснення збутової діяльності; наявність на державному рівні законодавчого пакету документів, які, не обмежуючи самостійність підприємства, регулюють його підприємницьку діяльність (виробничу, комерційно-збутову). На нашу думку, до організаційних чинників слід також віднести такі як розмір підприємства, його спеціалізація та географічна локалізація, віддаленість від підприємств-споживачів, їх кількість та особливості, наявність конкурентів, соціальна значущість вироблюваного продукту (товару);

-соціально-психологічні (значення галузі в цілому, як для економіки країни, так і для суспільства; ставлення держави до виробничо-практичної діяльності та ставлення підприємств до збутових посередників, кінцевих споживачів).

Автори сходяться на думці, що збутова політика, до складу якої комплексно входять такі 
політики як товароруху, цінова, договірна, товарна, інкасаційна (для роздрібної мережі), формування попиту і стимулювання збуту, транспортування продукції, а також усі теоретично існуючі і практично адаптовані до ринкових умов збутові стратегії маркетингу, служить основою відносно декомпозиції загальних цілей підприємства. Слід підкреслити, що збутова політика, яка сформульована на засадах цілей та завдань збуту, повинна відповідати загальній бізнес-концепції підприємства та прийнятому курсу (орієнтиру) дій останнього. Більш того, збутова політика підприємства повинна служити базою для розробки його постачальницької, виробничотехнологічної, інноваційної та фінансової політик [2].

Гаркавенко С.В. визначає наступні чинники, що впливають на систему збуту підприємства, поділяючи їх на три групи: чинники товару, положення підприємства й ринку [1, с. 194]. До чинників товару, які впливають на збут, ставляться: відмінність ціни даного товару від ціни аналогічних товарів конкурентів; взаємозамінність товару іншими товарами; непряма користь для покупця; рівень платоспроможного попиту на товар; залежність від необхідного для його виробництва встаткування.

Чинники положення підприємства, що впливають на збут, містять: загальне положення підприємства на ринку (сформований імідж, престиж підприємства з позиції самого підприємства й на думку споживачів і партнерів); фінансові кошти, які підприємство припускає виділити для проведення збутових заходів; гнучкість виробничої й збутової програми підприємства; загальна структура номенклатури продукції. До чинників ринку, що робить вплив на збут, ставляться: загальна місткість ринку, тип ринку; розподіл ринку між конкурентами (частки ринку основних конкурентів); чинність конкурентної боротьби, позиція підприємства в конкуренції; еластичність попиту (вплив цінової політики на величину попиту); число посередників у процесі руху товарів від виробника до споживача.

Хрупович С. С. та Борисова Т. М. [3, с. 35] відображають чинники впливу, що визначають організацію збутової діяльності підприємства наступним чином. Чинники зовнішнього середовища: конкуренти; правові акти; платоспроможність покупців; концентрація споживачів, їх територіальне розміщення; характер попиту на продукцію (повсякденний, індивідуальний, сезонний); галузеві особливості (ресурсне забезпечення; зовнішній товарообіг). Чинники внутрішнього середовища: канали розподілу; фінансові ресурси; обсяг і тип виробництва; права і відповідальність керівників та працівників підприємства; зміст операцій по підготовці продукції до реалізації.

Отже, на сьогоднішній день, коли конкуренція на ринку є надзвичайно гострою, формування ефективної збутової політики підприємства відіграє надзвичайну важливу роль. Формування збутової політики відбувається з урахуванням цілої низки факторів. Вдало розроблена збутова політика дає можливість підприємству прискорити товарообіг та максимізувати прибуток, задовольнивши при цьому в повному обсязі вимоги споживачів.

\section{Перелік використаних джерел:}

1.Гаркавенко С. С. Маркетинг: Підруч. для студ. екон. спец. вищ. навч. закл. / С. С. Гаркавенко - К.: Лібра, 2004. -708 с.

2.Петречко В.А. Чинники впливу на формування збутової політики підприємства / A. В. Петречко, Г. Ю. Ткачук [Електронний ресурс] - Режим доступу: https:/conf.ztu.edu.ua/wp-content/uploads/2017/01/407.pdf

3. Хрупович С. С. Теоретичні аспекти побудови системи управління збутовою діяльністю на промисловому підприємстві / С. Є Хрупович, Т. М. Борисова // Галицький економічний вісник. -2006 . - № 3. - C. $34-38$.

4. Чмихало Н. В. Формування ефективної збутової політики фармацевтичного підприємства в умовах нестабільного зовнішнього середовища / Н. В. Чмихало, І. Л. Оккерт, А. Б.Ольховська, Н. В. Сотнікова // Запорожский медицинский журнал. - 2010. - т. 12, № 3. C. $126-131$. 


\section{кандидат історичних наук доцент кафедри економіки ДВНЗ «Переяслав-Хмельницький ДПУ імені Григорія \\ м. Переяслав-Хмельницький, Київська область, Україна \\ Ph.D. in History, Associate Professor at the Chair of Economics SHEE «Pereiaslav- Khmelnytskyi Hryhorii Skovoroda State Pedagogical University», Pereiaslav-Khmelnytskyi, Kyiv \\ ГЛОБАЛІЗАЦЙНІ ПРОЦЕСИ В СУЧАСНИХ УМОВАХ ТРАНСФОРМАЦЇ̈ СВІТОВОЇ ЕКОНОМІКИ \\ GLOBALIZATION PROCESSES IN THE CURRENT CONDITIONS OF TRANSFORMATION OF THE WORLD ECONOMY}

Костик Євгеній

Сковороди,

Kostyk Yevhenii region, Ukraine

Важливою складовою і невід'ємною ознакою в сучасних умовах розвитку національних економік $є$ глобалізаційні процеси, які безпосередньо або опосередковано впливають на їхній розвиток, а відтак постає необхідність у досконалому вивченні теоретичних основ щодо поняття глобалізація, та розкритті концептуальних засади глобалізаційних процесів в умовах трансформації світової економіки.

Суть процесу глобалізації світової економіки полягає у стрімкому зростанні обсягів і різноманітності світових зв'язків, поширенні процесів, практик і структур від національного простору до глобальних масштабів, у результаті чого посилюється економічна взаємозалежність країн світу, а також формується відносно цілісна економічна система, що практично охоплює територію всієї планети і диктує власні правила гри національним державам [1, с. 129].

Слід зауважити, що сучасним етапом глобалізації є транснаціоналізація світової економіки. Почавшись у період після II світової війни, транснаціоналізація на зламі тисячоліть переходить у свою завершальну стадію. Прискорення процесу транснаціоналізації світової економіки стало можливим не тільки завдяки розширенню діяльності ТНК щодо освоєння «чужих» територій, але і - масштабним заходам щодо лібералізації ринків та активізації діяльності наднаціональних організацій [3, с. 118]. Однак, з точки зору тенденцій і перспектив розвитку глобальної економіки теза відносно кінця «територіалізму» передбачає новітній i, можливо, один із найважливіших для національних економік, контекст. Утвердження супратериторіальності (транскордонності) може означати для національних держав фактичну втрату «можливості і здатності розпорядження територією і iї ресурсами» [3, c. 12].

Ще одна тенденція, яка прослідковується у сучасній глобальній економіці - людиноцентризм, адже глобалізація має бути орієнтована на людину, іiі цінності та потреби. На цьому наголосив засновник і виконавчий директор Всесвітнього економічного форуму в Довосі Клаус Шваб у привітальному слові до учасників заходу, тема якого: «Глобалізація 4.0: формування глобальної архітектури в епоху четвертої промислової революції». «Глобалізація 4.0 має бути орієнтована на людину, бо ми зараз, фактично, маємо боротьбу між роботами та людьми і не хочемо стати рабами нових технологій. Тому Глобалізація 4.0 має бути орієнтована на людину, але разом 3 тим, бути більш всеохоплюючою», - сказав Шваб. Він наголосив на тому, що перед людством стоїть завдання - окреслити чіткі форми майбутнього, до якого ми прагнемо. «Ми хочемо використовувати нашу енергію заради майбутнього, ми прагнемо бути орієнтованими на майбутнє, а не займатися лише вирішенням кризових ситуацій. На разі дуже багато питань лежить у сфері вирішення 
глобального кризового менеджменту і ми повинні окреслити для себе своє майбутнє дуже чітко», - сказав директор Давоського форуму [4].

В міру того, як суспільство, котре складається з особистостей, завдяки глобалізації перетворюється на фінансову цивілізацію, в якій пріоритетне місце належить «економічній людині», а цивілізація в технос, який складається 3 людей-факторів, людей-ресурсів, взаємодія оператора і конкретної людини стає всезагальною формою буття людини. Ії цілі постають як відображення внутрішніх законів оптимізації і ефективного функціонування соціотехносу [5].

Така антропологічна реальність сучасного соціоекономічного і культурного буття не лише «високорозвинених країн», але й України. У такому стилі розвитку сучасної цивілізації досить мало часу залишається для внутрішньої продуктивної діяльності людини, зростанні об’єму іiі «душі». Глобалізованому індивіду в перегонах за успіхом турбуватися про внутрішнє життя - втрата часу, який є гроші. Такий тип людини - лідер не тільки в нашому суспільстві, але й прообраз віртуально-глобалістської людини-постлюдини, що веде до уніфікації та ентропії-особистостей, душ, мов, самодостатності, національної ідентичності [5].

Таке випробування посилює активацію інтелектуальних можливостей людини. Одним 3 найбільш важливих, суттєвих засобів, «важелів» протистояння (опору) глобалістському $є$ національне, розвиток якого бере на себе «Четверта хвиля», розробляючи програму управління і формування національного, отже, і людського генофонду.

Висновки. Отже, глобалізація соціально-економічних процесів розуміється як тенденція всезростаючої взаємоінтеграції територіальних виробничо-економічних систем в єдиний світовий відтворювально-господарський та ринково-інформаційний простір. Глобалізація розвитку супроводжується відповідною цьому процесові координацією фінансово-економічних, соціально-економічних, соціально-політичних, військовополітичних та інших заходів на національному й міждержавному рівнях. Економічні успіхи провідних країн світу грунтуються на талановитих, спонтанних макроекономічних рішеннях, які лише через деякий час стають загальновизнаною господарською практикою. Але такі макроуправлінські механізми роблять ставку на підтримку розвитку людського капіталу, який має особливий вплив на перспективи зростання національних економік країн, а відтак інвестиції в нього є свідомо безпрограшними, вигідними, оскільки дозволяють збільшити ефективність економічної системи, міру її продуктивності в найближчому майбутньому, що, у свою чергу, дасть можливість поліпшити життєвий рівень населення.

\section{Перелік використаних джерел:}

1. Крапівний I. В. Глобалізація: сутність, чинники та етапи розвитку. Вісник СУЖДУ. Серія Економіка, № 1. 2008. С. 129-137. URL: www.nbuv.gov.ua/portal/soc...29/Lojachev.pdf (дата звернення: 13.03.2019 р.).

2. Крапівний I. В. Глобалізація: сутність, чинники та етапи розвитку. Вісник СУЖДУ. Серія Економіка, № 1 2008. С. 129-137. URL: www.nbuv.gov.ua/portal/soc...29/Lojachev.pdf (дата звернення: 12.03.2019 р.).

3. Косолапов Н. Глобализация: территориально-пространственный аспект. Мировая экономика и международные отношения. 2005. № 6. С. 3-13.

4. Глобалізація має бути орієнтована на людину - директор ... URL: https://www.ukrinform.ua/rubric-world/2624815-globalizacia-mae-buti-orientovana-na-ludinudirektor-davoskogo-forumu.html (дата звернення: 15.03.2019 р.).

5. Ільїн В. Національна економічна стратегія України в умовах глобалізації світового господарства. URL: http://4hvylia.com/ukraina/natsionalne-i-hlobalne-v-ekonomichnomurozvytku-ukrainy-kreatyvy-antropolohichnoho-vymiru.html (дата звернення: 15.03.2019 p.). 
Левицький Віталій

Кандидат економічних наук доцент Тернопільський національний технічний університет імені Івана Пулюя,

м. Тернопіль, Україна

Швець Ігор

студент групи ППм-51,

Тернопільський національний технічний університет імені Івана Пулюя,

м. Тернопіль, Україна

Vitaliy Levytskyi

$\mathrm{PhD}$ (History)

Associate Professor,

Ternopil Ivan Pului National Technical University,

Ternopil, Ukraine

Igor Shvets

Student of group PPm-51,

Ternopil Ivan Pului National Technical University,

Ternopil, Ukraine

\section{ФІНАНСОВИЙ РЕЗУЛЬТАТ ДІЯЛЬНОСТІ ПІДПРИСМСТВА ЯК ЕКОНОМІЧНА КАТЕГОРІЯ ТА ОБ'СКТ АНАЛІЗУ FINANCIAL RESULT OF ENTERPRISE ACTIVITY AS AN ECONOMIC CATEGORY AND AN OBJECT OF ANALYSIS}

Забезпечення прогресивного економічного розвитку вітчизняної економіки, яка перебуває під негативним впливом світової фінансової кризи, пов'язане з вирішенням питання підвищення фінансових результатів (прибутків) діяльності промислових підприємств на основі своєчасного аналітичного оцінювання впливу зовнішніх і внутрішніх факторів. Саме тому виникає нагальна потреба в оцінюванні фінансових результатів діяльності промислових підприємств України із визначенням динамічних змін щодо величини обсягу реалізованої промислової продукції, індексу продукції промисловості та величини фінансового результату (прибутку) промислових підприємств. Позитивне значення фінансового результату є основним джерелом фінансування господарської діяльності підприємств.

Процес здійснення господарської діяльності суб'єктами господарювання передбачає ефективне поєднання великої кількості організаційних, трудових, матеріальних, фінансових тощо ресурсів.

Даний ефект вимірюється шляхом співставлення отриманого результату з витратами живої і уречевленої праці на його досягнення. Якість і обсяг виробленої продукції, продуктивність праці, рівень собівартості характеризують фінансові результати діяльності.

Етимологічно поняття «фінансові результати» трактують як різницю між доходами та витратами підприємства за певний час, «прибуток» - зростання, збільшення, приріст, зиск, «збиток» - матеріальні втрати, протилежність прибутку. Більшість авторів фінансовий результат асоціюють із отриманим прибутком. На думку Н. М. Дєєвої, прибуток - це грошове вираження між вартістю реалізованої продукції і витратами на ії виробництво. В умовах ринкової економіки він $є$ узагальнюючим показником фінансових результатів господарської діяльності підприємств, метою їхньої діяльності [1, с. 146]. С. В. Захарін вважає, що прибуток підприємства - це взагалі єдина форма його грошових накопичень, яка стимулює інноваційно-інвестиційний процес [2, с. 19]. Під прибутком вітчизняний економіст Р. В. Скалюк розуміє грошове втілення частини вартості додаткового продукту [3, с. 112]. А. М. Поддєрьогін визначає прибуток як частину поновленої вартості, виробленої i реалізованої, готової до розподілу. Таким чином, наголошується на важливості процесу реалізації виробленого продукту за кошти [4, с. 212]. I. А. Бланк одним із перших в Україні 
використовує поняття співвідношення ризику і доходу у своєму визначенні прибутку. На думку вченого, прибуток - це втілений у грошовій формі чистий дохід підприємця на вкладений капітал, що характеризує його винагороду за ризик здійснення підприємницької діяльності, та $\epsilon$ різницею між сукупним доходом і сукупними витратами у процесі здійснення цієї діяльності [5, с. 96].

На наш погляд, фінансовий результат дещо більш об’ємна категорія ніж прибуток, зокрема фінансовий результат - це один 3 найважливіших економічних показників, який узагальнює усі результати господарської діяльності та надає комплексну оцінку ефективності усієї діяльності. Поняття фінансового результату тісно пов'язане з поняттями прибутків і витрат.

У величині фінансових результатів безпосередньо віддзеркалюються усі аспекти діяльності господарюючого суб'єкта: технологія і організація виробництва, система внутрішнього та зовнішнього управління, особливості діяльності. Результатом господарської діяльності $€$ економічний іiі підсумок у грошовій формі, який має два «полюси» прояву: позитивний і негативний, тобто прибуток і збиток.

Враховуючи, що діяльність господарюючого суб'єкта може бути не тільки прибутковою, а й збитковою, формуватися за дією факторів внутрішнього і зовнішнього економічного середовища, в обліку й аналізі дають загальну оцінку фінансових результатів, які характеризуються системою абсолютних i відносних показників. Абсолютними показниками є суми прибутку (чи збитку) за структурою утворення чи розподілу i використання.

Відносні показники фінансових результатів - значення рентабельності, які характеризують відносний (у процентах) ступінь прибутковості вкладеного капіталу в цілому і за його структурою, здійснених витрат чи отриманого доходу. Ці показники розраховують залежно від мети оцінки відносної прибутковості.

Мета аналізу фінансових результатів визначити повноту та якість їх отримання, оцінку динаміки абсолютних і відносних показників, з'ясувати спрямованість, ступінь i частку впливу окремих факторів на зміну прибутку і рентабельності, виявити та оцінити можливі резерви їх зростання.

При аналізі фінансових результатів дослідження проводять у двох аспектах.

У першому аспекті фінансовий результат оцінюють як ступінь досягнення кінцевої мети та визначення ефективності виробничо-фінансової діяльності. Тут пріоритетною $€$ оцінка ступеня використання сприятливих можливостей та упущеної вигоди.

Другий аспект передбачає визначення пріоритетів вкладення капіталу за видами діяльності, за масштабами у стратегічному та тактичному вимірах, які дають максимальний приріст фінансового результату.

Узагальнюючи все вищезазначене, слід відмітити, що фінансовий результат - це один 3 найважливіших економічних показників, який узагальнює усі результати господарської діяльності та надає комплексну оцінку ефективності усієї діяльності. Поняття фінансового результату тісно пов'язане 3 поняттями прибутків і витрат. У величині фінансових результатів безпосередньо віддзеркалюються всі аспекти діяльності господарюючого суб'єкта: технологія і організація виробництва, система внутрішнього та зовнішнього управління, особливості діяльності, які визначають якість та обсяг виготовленого продукту, рівень собівартості, стан продуктивності праці тощо. Фінансові результати інтегровано відображають кількісні й якісні чинники діяльності підприємств.

\section{Перелік використаних джерел:}

1. Дєєва Н. М. Фінансовий аналіз. Навчальний посібник. / Н. М. Дєєва, О. І. Дедіков.К.: Центр учбової літератури, 2007.-328 с.

2. Захарін С. В. Прибуток як джерело інвестицій й інновацій / С. В. Захарін // Проблеми науки.-2007.-№ 7.-С. 10-19.

3. Скалюк Р. В. Сутність та значення фінансових результатів в системі розвитку 
господарської діяльності промислових підприємств / Р. В. Скалюк // Збірник наукових праць Кіровоградського національного технічного університету.-2010.-№18.-С.112-117.

4. Фінанси підприємств / Кер. авт. кол. і наук. ред. проф. А.М. Поддєрьогін.-4-те вид., перероб. та доп.-К.: КНЕУ, 2004.-571 с.

5. Бланк И.А. Управление прибылью / И.А. Бланк-К.: Ника-Центр, 1998.-544 с.

УДК 339.9

\author{
Левицький Віталій \\ кандидат історичних наук, доцент \\ Тернопільський національний технічний університет імені Івана Пулюя \\ м. Тернопіль, Україна \\ Vitaliy Levytskyi \\ PhD (History), Associate Professor \\ Ternopil Ivan Pului National Technical University \\ Ternopil, Ukraine
}

\title{
ГОЛОВНІ РИСИ ВКЛЮЧЕННЯ УКРАЇНИ В ГЛОБАЛІЗАЦІЙНІИ ПРОЦЕСИ THE MAIN CHARACTERS OF INCLUSION OF UKRAINE
}

\section{IN GLOBALIZATION PROCESSES}

Глобалізація, як процес глибинних трансформацій, який інтегрує економіку, культуру, технології та політику окремої країни у світове співтовариство шляхом формування нових складних взаємовідносин i взаємозв'язків між потоками капіталів, товарів, людських ресурсів та ідей, є чи не найбільш характерною рисою XXI ст. Глобалізація істотно впливає на економічне життя практично всіх країн світу i, звичайно, на Україну, яка цілком усвідомлено, активно і цілеспрямовано рухається в напрямку інтеграції в міжнародну економіку.

Для оцінки рівня глобалізації у 2002 році за сприяння Швейцарського економічного інституту (Swiss Federal Institute of Technology) та за участю Федерального Швейцарського технологічного інституту (Swiss Federal Institute of Technology) був започаткований Індекс глобалізації (KOF Index of Globalization), який являє собою комбінований показник, що дозволяє оцінити масштаб інтеграції окремо взятої країни у світові процеси. Індекс країн визначають за 24 показниками, об'єднаними в три основні групи глобалізації - економічну, соціальну та політичну, на основі спеціалізованих баз даних Всесвітнього банку, Міжнародного Валютного фонду, Організації Об'єднаних Націй та інших міжнародних організацій і статистичних інститутів. Показники, за допомогою яких оцінюють розвиток і потоки міжнародної торгівлі, рівень світової ділової активності, рух капіталів, дають змогу визначити рівень економічної глобалізації. Залучення країн до роботи в міжнародних організаціях, ратифікація міжнародних багатосторонніх договорів, участь у міжнародних місіях, кількість посольств і представництв в інших країнах та ін. - показники, які засвідчують рівень політичної глобалізації. Сума значень показників трьох груп із урахуванням коефіцієнтів вагомості $36 \%, 39 \%$ i 25\%, відповідно, становить Індекс глобалізації окремо взятої країни і дає можливість сформувати світовий рейтинг досліджуваних держав [2, с. 7].

Для того, щоб Україна вижила як самостійна держава, необхідно підвищувати конкурентноздатність економіки нашої країни, як з точки зору витрат на виробництво, так і 3 точки зору інвестиційної привабливості. При цьому, варто бути реалістами та усвідомлювати, що сьогодні ми володіємо обмеженою кількістю переваг, які здатні вивести українську економіку в лідери. Саме сировинна структура української економіки - головний фактор, що створює надзвичайну залежність від зовнішніх впливів. Слід визнати, що від цін 
на сировину на світових ринках протягом останніх двадцяти років залежить стан української економіки та державних фінансів, рівень зарплат та добробут мільйонів українських громадян. Вітчизняний сировинний великий бізнес об'єктивно не зацікавлений у збільшенні зарплат та доходів населення, у розвитку внутрішнього ринку, адже в цьому випадку прибутковість їхнього бізнесу 3 застарілими, немодернізованими підприємствами знижуватиметься. Саме тому українським підприємствам необхідно проводити модернізацію, вдосконалювати виробництво та якість продукції. Держава має вкладати кошти в розвиток інновацій та технологій, адже без цього ми і далі будемо відставати від розвинених економік світу, а згодом можемо просто перетворитися на державу-банкрут [4].

Позиція, яку зараз підтримує Україна, приведе до збільшення можливостей входження країни до великих міжнародних коопераційних проектів, що в перспективі можуть забезпечити істотне підвищення конкурентоспроможності та розширити можливості більш вільного доступу до зарубіжних ринків за рахунок зменшення тарифних і нетарифних перешкод. Але для України стратегічно важливою метою має стати стимулювання структурних реформ усередині країни, спрямованих на забезпечення конкурентоспроможності у відкритому ринковому середовищі, що є стратегічно важливою метою. На жаль, на сьогодні Україна недостатньо залучена до цих процесів, оскільки вона: 1) значно відстає від провідних держав світу в галузі інформатизації та розвитку інформаційних технологій; 2) перебуває лише на початку формування власних ТНК, конкурентоспроможних на глобальному рівні й здатних до здійснення глобальної стратегії розвитку; 3) досить непослідовно запроваджує економічну лібералізацію; 4) не звертає належної уваги на координацію своєї зовнішньоекономічної політики 3 іншими пострадянськими й постсоціалістичними країнами, що розвиваються. Тому глобалізація спричинює серйозні негативні наслідки - вона загрожує майбутньому людської цивілізації, шкідливо впливає на клімат, погіршує якість та рівень життя. Виникає пригнічення розвитку окремих галузей (секторів) національної економіки, які виявляються не готовими до повноцінної міжнародної конкуренції, заміщення їх імпортом [1, с. 31].

Показники розвитку української економіки у порівняні із найбільшими торговельними партнерами свідчать про недоречність беззастережного відкриття кордонів. Так, за даними Світового банку, ВНП на душу населення в Україні є одним з найнижчих у світі (вона посідає 135 місце). Виробничо-промисловий комплекс України нездатний адаптуватися до попиту на світовому ринку, про що говорить досить низький ВНП на душу населення. Через не конкурентоспроможність занепадають цілі галузі [3, с. 113].

Таким чином, саме ці питання вимагають особливо пильної уваги. Глобальні проблеми не можна вирішити швидко і на рівні окремих країн. Необхідний єдиний міжнародний механізм їх вирішення і регулювання, визначення міжнародних правових i економічних норм. Великі надії в розв'язанні глобальних проблем покладаються на ООН, МВФ, СОТ, регіональні і галузеві організації, які мають великий досвід координації міжнародних зусиль, використання ресурсів, регулювання міжнародних економічних відносин. Процес глобалізації міжнародної економіки не оминає і Україну, яка поступово займає своє місце в системі нового міжнародних економічних відносин, і активно впливає на всі аспекти економічного розвитку України. Потенціал України для участі у глобальних ринках досить високий, але Україна на сучасному етапі недостатньо повно використовує його через незавершені реформи.

\section{Перелік використаних джерел:}

1. Ботвіна Н. О. Вплив глобалізаційних та інтеграційних процесів на економічну безпеку України // Економічний аналіз: зб. наук. праць. Тернопільський національний економічний університет; редкол.: В. А. Дерій (голов. ред. ) та ін. Тернопіль: Видавничополіграфічний центр Тернопільського національного економічного університету «Економічна думка», 2014. Том 16. № 1. С. 28-33 
2. Герасименко Т. О. Динаміка глобалізаційних процесів в Україні за часів іiі незалежності // Фінансово-економічний розвиток України в умовах євроінтеграції: збірник матеріалів IV всеукраїнської науково-практичної Інтернет-конференції, 25 березня 2015 р. Львів: ЛКА, 2015. С. 7-8.

3. Каїра Л. Г., Титар К. А. Україна і сучасні процеси світової економічної глобалізації // Збірник наукових праць з гуманітарних дисциплін «Славута». Вип. 6. 2013. С. 112-114.

4. Чмерук Т. Глобалізація світової економіки та місце в ній України // Електронний pecyрс. Режим доступу: https://ua.112.ua/mnenie/hlobalizatsiia-svitovoi-ekonomiky-ta-mistseukrainy-u-nii-428876.html

УДК 378

Пастух Марія
студентка групи ПЕ-41

Тернопільський національний технічний університет імені I. Пулюя м. Тернопіль, Україна

Maria Pastukh

Student of the group PE-41

Ternopil Ivan Puluj National Technical University

Ternopil, Ukraine

Бажанова Наталія

кандидат економічних наук,

доцент кафедри економіки та фінансів

Тернопільський національний технічний університет імені І. Пулюя,

м. Тернопіль, Україна

Bazhanova Natalia

$\mathrm{PhD}$ (Economics), Associate Professor

Department of Economics and Finance

Ternopil Ivan Puluj National Technical University, Ternopil, Ukraine

\section{НАВЧАННЯ, ЩО СПОНУКАС ДО КАРДИНАЛЬНИХ ЗМІН LEARNING THAT DRIVES SIGNIFICANT CHANGES}

Актуальність. Останнім часом проблема змін в $\underline{\epsilon}$ надзвичайно актуальною. Україна у сфері освіти стоїть на шляху великих змін та реформ. На сьогодні, сучасний світ посилає багато викликів у даній сфері. Сучасні цивілізаційні зміни, потребують нових підходів та методик щодо підготовки фахівців в усіх сферах.

Аналіз останніх досліджень і публікацій відомих українських, польських та російських вчених В. Г. Кременя, І. А. Зязюна, В. П. Андрущенка, Н. Г. Ничкало, С. О. Сисоєвої, Н. А. Сейко, М. А. Козловця, А. А. Герасимчука, М. Ф. Головатого, О. А. Дубасенюк, О. Є. Антонової, І. Й. Осинського, Тадеуша Левовицького, Стефана Мишальського, дає уявлення про те, що дана тематика $є$ не достатньо дослідженою.

Виклад основного матеріалу. Цивілізація увійшла у новий етап - інноваційний. Постійні зміни, динаміка, збільшення можливостей, що дають сьогоднішні технології вимагають підготовку фахівців іншого покоління. Часто стримуючим фактором є покоління людей, які просто не готові до таких змін. Оскільки сучасні знання дуже швидко стають не актуальними, постійно виникає потреба в нових знаннях. Отже, необхідно по-іншому визначити методологію навчання і функції навчального процесу.

Комунікативне середовище, в якому живе i діє людина за останні 10 років надзвичайно змінилося. Сучасна молодь зовсім по-іншому визначає своє коло комунікацій, тому і відносини між тим, хто навчає, і тим, хто навчається, теж змінились. Сьогодні поняття авторитарної репресивної педагогіки практично не існує, все частіше педагогіка $\epsilon$ 
демократичною, толерантною і будується на співпраці та довірі, як в школах, так і в університетах.

Розвиток людства набув глобального характеру, що дає можливість кожному розвиватись у глобальному просторі, бути конкурентоспроможним та підлаштовуватись до будь-яких умов. По-четверте, сучасний світ не лише поставив нові завдання, а й створив для освіти нові можливості. Передусім це сучасні інформаційні технології, які забезпечують як мінімум три функції: комп'ютерну грамотність, індивідуалізацію та інтенсифікацію освітнього процесу, а також новий тип навчальної діяльності - дистанційна освіта.

Одним $з$ цікавих підходів можна вважати ідею дитиноцентризму, який передбачає максимальне наближення навчання кожної людини до іiі потреб, інтересів, індивідуальності. Просуваючи дану ідею, можна уникнути проблеми вибору випускниками професій, які їм нав'язали: батьки, друзі, вчителі ,суспільство.

Сьогодні освіта в Україні потребує широкого впровадження сучасних засобів навчання та інформаційно-комунікаційних технологій. Це дасть можливість якіснішого навчання та розвитку практично у всіх сферах, доступ до спеціалізованої інформації.

Осучаснення, розвантаження від непотрібного матеріалу, у більшій мірі практичного застосування, дасть можливість українській освіті розробити більш системні перетворення, що дадуть можливість забезпечити вирішення проблем, котрі сьогодні постають перед Україною.

Висновки. Отже, використання нових, сучасних методів підготовки, які враховують освітні потреби особистості студента та забезпечують процеси формування системного бачення майбутньої професійної діяльності та професійної компетентності дадуть країні спеціалістів, яких вона потребує на сучасному етапі.

\section{Перелік використаних джерел:}

1. Биков В. Ю. Ключові чинники та сучасні інструменти розвитку системи освіти [Електронний ресурс] / В. Ю. Биков // Інформаційні технології і засоби навчання.- 2007. Вип. 2. - Режим доступу :_URL:http://www.nbuv.gov.ua/e-journals/ITZN/em2/emg.html

2. Кобильник Т. П. Компетентнісний підхід при вивченні «математичної інформатики» у педагогічному університеті [Електронний ресурс] / Т. П. Кобильник // Інформаційні технології і засоби навчання. - 2007. - Вип. 2. - Режим доступу: http://www.nbuv.gov.ua/e-journals/ITZN/em2/emg.html

3. Табачник Д. В. Навчання формує особистість ЗДОБУТКИ. Позитивні результати реформування - інвестиції в майбутнє країни [Електронний pecypc] / Табачник Д. В. //Урядовий кур'єр.- 2012. -Режим доступу:URL: http://ukurier.gov.ua/media/documents/2012/10/31/200_4844s.pdf

4. Кремень В.Г. Як нам реорганізувати освіту [Електронний ресурс] / Кремень В. Г. //Міжнародний громадсько-політичний тижневик «Дзеркало тижня»- 2017. Вип. 13 -Режим доступу:URL: https://dt.ua/EDUCATION/yak_nam_reorganizuvati_osvitu.html 
УДК 330.341 .1

Підоричева Ірина завідувач сектором проблем інноваційно-інвестиційного розвитку промисловості Інститут економіки промисловості НАН України

м. Київ, Україна

Iryna Pidorycheva

head of the Sector for Problems of the Innovation and Investment Development in Industry, Institute of Industrial Economics of the NAS of Ukraine

Kyiv, Ukraine

\section{ФОРМУВАННЯ ІННОВАЦИЙНИХ ЕКОСИСТЕМ В УМОВАХ ГЛОБАЛІЗАЦЇ̈ FORMING INNOVATION ECOSYSTEMS IN THE CONTEXT OF GLOBALIZATION}

Остання хвиля інновацій, пов'язана з глобалізацією та початком цифрової революції, різко змінила соціальну, економічну та політичну реальність. Бездротові технології (Bluetooth, Wi-Fi, GPRS тощо) та Інтернет породили величезні потоки інформації, занулили фізичні відстані між людьми, спричинивши високий динамізм середовища, зростання ступеня непередбачуваності подій та рівня взаємозалежності економічних агентів.

Поширення Інтернет сформувало суспільство нового типу - мережеве суспільство, а завдяки ньому - нову (мережеву) економіку, відмінною особливістю якою $є$ не просто великі обсяги інформації, а зовсім інша логіка іiі використання та розповсюдження, заснована на інформаційно-комунікаційних технологіях та мережах [1, с. 14-15]. Яскраво ілюструють масштаби сучасної глобалізації слова виконавчого директора індійської технологічної компанії Infosys Надана Нілекані (Nilekani). Демонструючи конференц-зал та екран (в якому було з'єднано сорок цифрових моніторів і який на той час був, напевно, найбільшим в Азії), Нілекані розповів, що завдяки цьому пристрою Infosys здатен у будь-який момент зібрати віртуальну нараду з усіма ключовими партнерами, розташованими в будь-якій точці земної кулі. Американські замовники, індійські програмісти, виробники з Південно-Східної Азії або, наприклад, якщо кінцевий продукт виготовляється в Сінгапурі, то підключається людина з Сінгапуру - всі наживо спілкуються і обговорюють роботу над проектом. Як висловився Н. Нілекані, «ось воно, обличчя глобалізації» [2, с. 6].

Дійсно, у відносно стабільному неконкурентному середовищі 3 обмеженими комунікаціями, яке притаманне закритим економікам індустріальної доби та деяким сучасним економікам (наприклад, Північній Кореї), розповсюджені централізовані ієрархії 3 жорсткими вертикальними зв'язками і директивними методами управління. У ринковій економіці, яка на чільне місце ставить свободу дій учасників і розвиток вільного конкурентного середовища, механізми координації зв'язків, навпаки, є надто хаотичними та слабо узгодженими. У сучасну епоху глобалізації, яку Томас Фрідман назвав Глобалізацією 3.0, ці моделі не спрацьовують, все частіше піддаються критиці і сумніву [2, c. 48]. На їх місце приходять відкриті, неієрархічні партнерства, побудовані на горизонтальних зв'язках, довірі і колективній співпраці, нерідко віртуальній та онлайновій.

Розвиток мережевої економіки змінює і модель інноваційного процесу - 3 лінійної, яка передбачає послідовну зміну етапів та учасників, що в них задіяні (від фундаментальної науки до прикладних досліджень, впровадження та комерціалізації), до нелінійної, в якій ідеї для інновацій приходять 3 різних джерел на будь-якому етапі інноваційного ланцюга. Так, технологічні відкриття можуть передувати, а не грунтуватися на фундаментальних дослідженнях, або з'являтися безпосередньо у виробничому процесі [3, с. 24]. Це означає, що інноваційний процес стає все більш інтерактивним і коллаборативним [ ${ }^{1}$, с. 23], часто

${ }^{1}$ Коллаборація є вищим рівнем колективних взаємодій незалежних суб'єктів порівняно 3 координацією та співробітництвом. Вона представляє собою «процес, в якому автономні 
міждисциплінарним і різноспрямованим [3, с. 24]. Виготовлення нових продуктів рідко здійснюється виключно виробниками, замість цього сучасні продуктові, сервісні і технологічні інновації все частіше продукуються в інтерактивному режимі учасниками мереж, побудованих як коллаборації. У науковій літературі вони іменуються інноваційними екосистемами. Додавання приставки «еко» до поняття «система» робить акцент на важливій умові створення інновацій в сучасних умовах: необхідності формування мережевого (нелінійного - відкритого, динамічного, пластичного) середовища, заснованого на горизонтальних зв'язках між незалежними учасниками, які мають спільне бачення щодо бажаних перетворень. Такі мережі можуть формуватися на різних рівнях - від локального до глобального - всюди, де природним шляхом встановлюються стійкі взаємозв'язки між економічними агентами.

Поряд зі зростаючими процесами глобалізації, інноваційна діяльність все більшою мірою тяжіє до регіонального (локального) рівня [4, с. 36-84]. Передача знань у практику є більш ефективною в регіонах і містах завдяки безпосередньому спілкуванню між суб'єктами інноваційної діяльності на відміну від застосування довгих каналів зв'язку на макрорівні. Зокрема, у дослідженні Організації економічного співробітництва та розвитку зазначається, що найбільш інтенсивна взаємодія між учасниками, задіяними в інноваційних процесах, відбувається в радіусі близько 200 км [5, с. 15].

В Україні взаємозв'язки між учасниками інноваційних процесів $є$ слабкими i фрагментарними, існують розриви як за двовекторними комунікаціями («бізнес-наука», «бізнес-освіта», «наука-освіта», «бізнес-освіта»), так і між цими трьома суб’єктами інноваційної системи. Співавторство між наукою і підприємствами при підготовці публікацій зустрічається рідко, а трансфер технологій є непоширеним явищем у виробництві. Так, кількість малих і середніх підприємств (МіСП), які мали угоди про співпрацю у сфері інновацій з іншими підприємствами та науковими установами впродовж останніх трьох років, складає лише 1,5 \% загальної кількості МіСП, тоді як у Європейському Союзі (ЄС) цей показник в середньому дорівнює 11,2 \%, а у деяких країнах (Бельгія, Великобританія, Ісландія, Австрія) - навіть перевищує 20 \% [7, с. 89-90, 96]. Незначним є попит на інновації 3 боку промислових підприємств, який до того ж сконцентрований здебільшого на закупівлі зовнішніх технологій і обладнання: на цей напрям інноваційної діяльності припадає 64,7 \% загального обсягу витрат на інновації [8, с. 90]. Витрати вітчизняного бізнесу на проведення науково-дослідних і дослідно-конструкторських робіт складають лише $0,38 \%$ ВВП, що в рази менше, ніж в СС [7, с. 90]. Така індиферентність підприємств до інновацій не компенсується належною державною підтримкою інноваційної сфери та системою стимулювання іiі розвитку.

Усе вищезазначене дозволяє зробити висновок, що проблеми формування цілісної інноваційної екосистеми в Україні є вельми складними і потребують вироблення адекватних сучасним умовам пропозицій щодо їх вирішення. Незважаючи на численність робіт, присвячених інноваціям, лише незначна їх кількість приділяє увагу проблемам запуску інновацій на системному рівні, досі немає однозначної відповіді не те, чому лише деяким регіонам вдалося повторити успіх Кремнієвої долини і побудувати дієздатні інноваційні екосистеми. В умовах становлення мережевої економіки, розвитку глобалізації та локалізації інноваційних процесів ці питання потребують чергового переосмислення та вироблення концептуального бачення щодо напрямів формування в Україні національної та регіональних інноваційних екосистем.

гравці взаємодіють між собою через формальні та неформальні переговори, спільно формуючи правила і структури для регулювання своїх взаємодій та напрямів діяльності або вирішують спільні завдання». Див.: [6, с. 23]. 


\section{Перелік використаних джерел:}

1. Мануэль Кастельс Галактика Интернет: Размышления об Интернете, бизнесе и обществе /Пер. с англ. А. Матвеева; под ред. В. Харитонова. Екатеринбург: У-Фактория (при участии изд-ва Гуманитарного ун-та), 2004. 328 с.

2. Friedman T.L. The World is Flat: A Brief History of the Twentieth Century. Farrar, Straus and Giroux, NY. 2005. 674 p.

3. Rising to the Challenge: U. S. Innovation Policy for the Global Economy. National Research Council. National Academies Press, Washington, DC. 2012. 599 p.

4. Україна в європейському науково-освітньому та інноваційному просторі: концепція адаптації та інтеграції в умовах Угоди про асоціацію з Свропейським Союзом: монографія / С. В. Іванов, В. І. Ляшенко, І. Ю. Підоричева та ін.; НАН України, Ін-т економіки пром-сті. Київ, 2018. - 331 с.

5. Regions and Innovation: Collaborating across Borders. OECD Reviews of Regional Innovation, OECD Publishing. Paris. 2013. URL: http://dx.doi.org/10.1787/9789264205307-en

6. Thomson A.M., Perry J.L. Collaboration Processes: Inside the Black Box. Public Administration Review. Special Issue. 2006 December. P. 20-32.

7. Innovation Union Scoreboard 2018. European Commision. doi:10.2873/447902. URL: https://ec.europa.eu/docsroom/documents/32503.

8. Наукова та інноваційна діяльність України у 2016 році: стат. зб. К.: Державна служба статистики України, 2017. 141 с.

УДК 338.24:004(075.8)

Струтинська Ірина

кандидат економічних наук, доцент кафедри комп’ютерних наук Тернопільський національний технічний університет імені Івана Пулюя,

м. Тернопіль, Україна

Iryna Strutynska

$\mathrm{PhD}$ (Economics), Associate Professor of the Department of Computer Science

Ternopil Ivan Puluj National Technical University

Ternopil, Ukraine

\section{ПЕРЕДУМОВИ ТРАНСФОРМАЦІЇ ДЕРЖАВИ ТА БІЗНЕСУ В УМОВАХ ЦИФРОВОЇ ЕКОНОМІКИ \\ BACKGROUNDS TRANSFORMATION OF THE STATE AND BUSINESS IN THE CONDITIONS OF THE DIGITAL ECONOMY}

Цифрові технології стали базою для створення нових продуктів, цінностей, властивостей та, відповідно, основою отримання конкурентних переваг на більшості ринків. На сьогодні відбувається «цифровий перехід» від свого роду «аналогових» систем та процесів індустріальної економіки та інформаційного суспільства до «цифрової» економіки та «цифрового» суспільства. Така трансформація приводить до появи нових, унікальних систем і процесів, що складають їх нову ціннісну сутність (наприклад Uber, Airbnb, цифровий банкінг i т. д). До цифрових трансформацій схильні більшість звичних для громадян видів діяльності.

Цифрова трансформація - це перетворення бізнесу, держави шляхом перегляду бізнесстратегії або цифрової стратегії, моделей, операцій, продуктів, маркетингового підходу, цілей тощо, шляхом застосування цифрових технологій [1]. Перетворення - це завжди можливості, виклики та проблеми. Саме тому, плануючи проведення цифрових перетворень, організації повинні враховувати усі бар'єри та виклики, 3 якими їм прийдеться зіткнутися. Такі радикальні перетворення вимагають від людей нових знань, навичок та ефективної адаптації. Структурування основних зовнішніх та внутрішніх передумов та викликів до цифрової 
трансформації країни, вітчизняних бізнес-структур та визначення основних завдань інтеграції в єдиний цифровий ринок ЄС є надзвичайно актуальним питанням.

Перша передумова зовнішнього рівня, щзо спричинила значні виклики для цииррової трансформації - «Розвиток та перехід світової економіки до Епохи Індустрії 4.0». Слід розуміти, що загальні рівні розвитку світової економіки та економіки України суттєво різняться. Світова економіка активно використовує можливості епохи «Четвертої промислової революції» та отримує важливі результати. Характерні риси Індустрії 4.0 - це повністю автоматизовані виробництва, на яких керівництво всіма процесами здійснюється в режимі реального часу і з урахуванням мінливих зовнішніх умов. Кіберфізичні системи створюють віртуальні копії об'єктів фізичного світу, контролюють фізичні процеси i приймають децентралізовані рішення. Вони здатні об'єднуватися в одну мережу, взаємодіяти в режимі реального часу, самоналагоджуватися і самонавчатися. Важливу роль відіграють інтернет-технології, що забезпечують комунікації між персоналом та машинами. Підприємства виробляють продукцію відповідно до вимог індивідуального замовника, оптимізуючи собівартість виробництва [2].

Економіка України перебуває на етапі завершення третьої цифрової революції (Industry 3.0). Ï̈̈ характерні риси - розвиток інформаційно-комунікаційних технологій, автоматизація та роботизація виробничих процесів, цифровізація усіх сфер діяльності бізнесструктур.

Виявлення взаємозв'язків Індустрій 3.0 та 4.0, їх проявів за значущості дасть можливість виробити стратегію для переходу та інтеграції вітчизняного бізнесу до впровадження технологій Індустрії 4.0. Аналіз характеристик двох індустрій показує, що перехід до Індустрії 4.0 неможливий без виконання основних засад і вимог Індустрії 3.0.

Основні драйвера розвитку. Використання технологій Big Data, Business Intelligence (BI) та штучного інтелекту для МСБ. Для ефективного використання технологій Big Data, Business Intelligence (BI) та штучного інтелекту для МСБ $є$ низький рівень, або й відсутність розуміння сутності цих понять та можливостей використання відповідних технологій для оптимізації бізнес-процесів та бізнес-моделей організації. Використання великих даних може дати велику конкурентну перевагу. Для цього їх збір, обробка та аналіз повинні супроводжуватись відповідною грамотною стратегією і готовністю бізнесу до змін.

Друга передумова зовнішнього рівня, щзо спричинила значні виклики для цчифрової трансформації вітчизняних бізнес-структур «Цифровий порядок денний Європи 2020 (Digital Agenda for Europe 2020)». Прийнятий ЄС у 2010 році документ «Цифровий порядок денний для Європи 2020» («Digital agenda for Europe 2020») [3], відображає один із стратегічних орієнтирів розвитку Європи у рамках стратегії «Свропа 2020» та містить перелік із 100 конкретних дій i визначає європейську стратегію для розквіту цифрової економіки у 2020 році. Розроблена в травні 2015 року у рамках Цифрового порядку СС стратегія Сдиного цифрового ринку (Digital Single Market), що означало інтеграцію 28 національних цифрових ринків країн ЄС у єдиний цифровий простір. Сдиний цифровий ринок відкриває нові можливості, оскільки він усуває ключові відмінності між онлайн і оффлайн-світами, усуває бар'єри для транскордонної онлайн-діяльності.

Перша передумова внутрішнього рівня, щзо спричинила значні виклики для циифрової трансформачії вітчизняних бізнес-структур - «Цифровий розвиток окремих бізнесструктур («циифровий розрив»)». Найбільш активні гравці, а саме IT-компанії та Агрохолдинги, що працюють з іноземним капіталом, почали самостійно трансформувати власні бізнес-моделі, беручи за основу світовий досвід та тенденції технологічного розвитку країн світу. Однак при позитивних зрушеннях бізнес стикався із багатьма перешкодами, спричиненими як неготовністю нашої економіки до цифрових трансформацій, так відсутністю законодавчої, технічної інфраструктури та цифрової грамотності громадськості.

Друга передумова внутрішнього рівня, щзо спричинила значні виклики для циифрової трансформації - «Цифрова адженда України - 2020)» [4]. Обравши напрямок руху у ЄС, Україна повинна реалізувати багато задач, щоб стати повноправним членом європейського 
цифрового ринку. Так, у 2016 році світові лідери «цифрового» ринку - Cisco, IBM, Intel, Oracle, Deloitte, SAP, Ericsson, MasterCard, Vodafone, Kyivstar, Lifecell, International Data Corporation, вітчизняні консультанти та експерти, підтримані Міністерством економічного розвитку та торгівлі та ГО «ХайТек Офіс», розробили «Цифровий порядок денний України 2020», - документ, який визначає ключові напрямки, першочергові сфери, ініціативи та проекти «цифровізації» України на найближчі 3 роки. Проте довгоочікувану «Концепцію цифрової економіки та суспільства на 2018-2020 роки» КМУ затвердив лише у січні 2018 року. Для розвитку власного цифрового ринку та гармонізації його iз Digital Single Market CС у тому ж 2018 році КМУ було затверджено план заходів щодо реалізації «Концепції цифрової економіки та суспільства на 2018-2020 роки» [5]. План містить 34 завдання до виконання. Більшість із них повинні були бути досягнені у 2018 році, та багато із запланованих завдань не вдалося зреалізувати, саме тому їх виконання відтерміновано до виконання у 2019-2020 роках.

\section{Перелік використаних джерел:}

1.Цифрова трансформація. [Електронний ресурс]. - Режим доступу: https://uk.wikipedia.org/wiki/\%D0\%A6\%D0\%B8\%D1\%84\%D1\%80\%D0\%BE\%D0\%B2\%D0\%B0 $\% \mathrm{D} 1 \% 82 \% \mathrm{D} 1 \% 80 \% \mathrm{D} 0 \% \mathrm{~B} 0 \% \mathrm{D} 0 \% \mathrm{BD} \% \mathrm{D} 1 \% 81 \% \mathrm{D} 1 \% 84 \% \mathrm{D} 0 \% \mathrm{BE} \% \mathrm{D} 1 \% 80 \% \mathrm{D} 0 \% \mathrm{BC} \% \mathrm{D} 0 \%$ B0\%D1\%86\%D1\%96\%D1\%8F

2. Індустрія 4.0. [Електронний ресурс]. - Режим доступу: https://www.it.ua/knowledgebase/technology-innovation/industry-4

3. Digital agenda for europe 2020. [Electronic resource]. - Access mode: pdfhttps://eurlex.europa.eu/legal-content/EN/TXT/PDF/?uri=CELEX:52010DC0245R(01)\&from=EN

4. Цифрова адженда України - 2020. [Електронний ресурс]. - Режим доступу: https://ucci.org.ua/uploads/files/58e78ee3c3922.pdf

5. Розпорядження КМ України «Про схвалення Концепції розвитку цифрової економіки та суспільства України на 2018-2020 роки та затвердження плану заходів щодо іiі реалізації» [[Електронний ресурс]. - Режим доступу: https://www.kmu.gov.ua/ua/npas/proshvalennya-koncepciyi-rozvitku-cifrovoyi-ekonomiki-ta-suspilstva-ukrayini-na-20182020-roki-tazatverdzhennya-planu-zahodiv-shodo-yiyi-realizaciyi 


\title{
СЕКЦІЯ 3 \\ РОЛЬ ТА ПОТЕНЦАЛ ВІТЧИЗНЯНОГО ПІДПРИЕМНИЦТВА У РОЗВИТКУ ЕКОНОМІЧНО СТІЙКОЇ ДЕРЖАВИ
}

УДК 005.21:005.7:658

\author{
Власенко Тетяна \\ кандидат економічних наук \\ Харківський національний технічний університет сільського господарства \\ імені Петра Василенка \\ м. Харків, Україна \\ Tetiana Vlasenko \\ $\mathrm{PhD}$ in Economics \\ Kharkiv Petro Vasylenko National Technical University of Agriculture \\ Kharkiv, Ukraine
}

\section{НАУКОВО-МЕТОДОЛОГІЧНІ ЗАСАДИ СТРАТЕГІЧНИХ ЗМІН В ДІЯЛЬНОСТІ ПІДПРИЕМСТВА SCIENTIFIC-METHODOLOGICAL BASES OF STRATEGIC CHANGES IN THE ENTERPRISE ACTIVITY}

Визначення напрямів діяльності підприємства у довгостроковій перспективі традиційно відноситься до сфери стратегічного управління. А високий рівень динаміки зовнішнього та внутрішнього середовища вимагає розробки та впровадження сучасної концепції стратегічних змін. Незважаючи на важливість та нагальність вирішення даного завдання становлення наукової школи стратегічних змін у вітчизняній науці лише розпочинається, саме тому визначення сутності стратегічних змін та методології управління ними є актуальним завданням. Питаннями дослідження сутності стратегічних змін займалися такі закордонні науковці як: Дж. Балогун, Д. Джоя, М. Зундел, Л. Каммінгс, С. Кларк, Дж. Корнелісен, С. Мантер, Е. Романеллі, Дж. Сіллінц, Б. Став, М. Ташман, Дж. Томас, Р. Холт, К. Читтепедді, Х. Шильдт, С. Флоід та інші. Серед українських варто виокремити: Д. К. Воронков, О. В. Гронь, І. В. Ліганенко, В. І. Отенко, І. В. Сокирник.

Існуючи визначення стратегічних змін $є$ досить різнонаправленими. Крім того вимагає уточнення різниця між поняттями «стратегічні зміни», «стратегії змін» та «зміна стратегії», які хоча і $€$ близькими за значеннями, мають принципово різні дефініції. Розроблено ряд концепцій, які можуть бути віднесені як до стратегічних, так і в цілому до організаційних змін. Для визначення сутності досліджуваного поняття варто визначитися із його складовими: «стратегія» та «зміни». В роботі [1] надано узагальнення підходів до їх розуміння. Проведений аналіз результатів досліджень авторів, які включають узагальнення визначень поняття «стратегія» дозволяє надати власні риси досліджуваній категорії для подальшої детермінації сутності стратегічних змін.

По-перше, стратегія повинна охоплювати як загальнокорпоративний рівень, так і конкурентну позицію підприємства на ринку. Крім того, вона виступає методологічним базисом управління підприємством в довготривалій перспективі, виступаючи як метою прийняття управлінських рішень, так і засобом для забезпечення успішності діяльності підприємства.

По-друге, стратегія повинна як відображати сукупність цілей, бажаних для підприємства, так і правила їх постановки. 3 нашої точки зору, із цілями тісно пов’язані 
ресурси, координація та розподіл яких необхідні як управлінські дії в досягненні поставлених цілей.

По-третє, саме стратегія в найбільшій мірі порівняно 3 іншими інструментами управління діяльністю підприємства $є$ результатом аналізу стану підприємства у зовнішньому середовищі та відображає характер взаємодії підприємства із зовнішнім середовищем. Це віддзеркалює як іiі довготривалий характер, так і необхідність врахування всіх можливих варіантів змін стану зовнішнього середовища як за складом, так і за динамікою.

По-четверте, визначення стратегії як конкретного поняття, як наприклад: модель, або перспектива, або програма, або погляд $\epsilon$ достатньо складним завданням через великий обсяг охоплення складових, які іiі становлять. Отже, для об'єднання їі методологічного та практичного характеру варто запропонувати бачення стратегії як «управлінського інструментарію».

По-п’яте, досить розповсюджене бачення стратегії як плану є значно звуженим, але необхідність формалізації стратегії як довгострокового плану є критично важливим в рамках поточної діяльності підприємства.

Існує ряд визначень поняття «зміни», але їх варто згрупувати за подібністю розумінь ïx сутності. В роботі [2] надано ключові характеристики поняття «зміни». На основі проведеного аналізу запропонуємо авторське розуміння змісту стратегічних змін.

По-перше, стратегічні зміни є особливим специфічним типом організаційних змін. Їх характер на відміну від організаційних, які можуть бути спровоковані внутрішніми проблемами, завжди обумовлений взаємодією із зовнішнім середовищем, а їх реалізація відображає позиціонування підприємства на ринку для забезпечення утримання існуючих конкурентних переваг та набутті нових. Якщо сутність організаційних змін - перехід до бажаного стану, обумовленого цілями діяльності, а їх масштаб та характер залежить від складності даного переходу, то стратегічні зміни включають необхідність окреслення профілю бажаного стану разом 3 управлінськими інструментарієм забезпечення його детермінації. Успішність стратегічних змін залежить від формування динамічних здатностей підприємства та компетентностей персоналу. Взаємодія із зовнішнім середовищем обумовлює і пріоритетні цілі здійснення стратегічних змін, які полягають у забезпеченні належного рівня ефективності, включаючи високий рівень рентабельності, покращення ступеня відповідності вимогам зовнішнього середовища шляхом адаптації та пристосування, все в цілому становить сутність розвитку підприємства.

По-друге, беручи до уваги розуміння дослідниками системних елементів підприємства, які мають бути змінені, стратегічні зміни торкаються найбільш важливих та значущих підсистем, до яких доцільно віднести місію, сукупність цілей діяльності та цінностей, ключових бачень тощо. Більшість інших елементів мають допоміжне значення, адже їх зміни повинні бути націлені на досягнення поставлених в рамках стратегічних змін завдань. Це стосується таких понять як організаційна структура, культура, ієрархія, стиль лідерства та управління. Їх трансформації не повинні виступати цілями будь-яких змін на підприємстві, а лише засобами для досягнення.

По-третє, специфічність стратегічних змін пов'язана ще й з подоланням розриву між планування та реалізацією стратегії. Такий розрив виникає в разі недосконалості формулювання стратегії, некоректного розподілу ресурсів для іiі досягнення або в разі надшвидкої зміни умов зовнішнього середовища, які вимагають радикальних змін стратегії та планів діяльності, що призводить до зупинки окремих проектів та програм роботи підприємства і вимагає негайного втручання в існуючу стратегію.

По-четверте, на відміну від організаційних змін, вони не стільки забезпечують перенесення підприємства у бажаний стан, скільки створюють передумови для спроможності підприємства змінюватися в цілому для забезпечення конкурентоспроможності підприємства в довгостроковій перспективі. Фактично це передбачає перерозподіл наявних ресурсів як для забезпечення поточного функціонування підприємства, так і для створення потенціалу зростання. Стратегічні зміни для вітчизняних підприємств передбачають формування 
методології управління, направленої на проактивне формування стратегії, що включає розробку моделей управління, принципів, методів та відповідного забезпечення.

Таким чином, в результаті стратегічних змін підприємства повинно сформувати конфігурацію організаційної структури, технологій, процесів, процедур навчання та підвищення кваліфікації кадрів, які в майбутньому мають забезпечувати ефективне функціонування підприємства як реакцію до вимог зовнішнього середовища та як відповідь на його ризики.

\section{Перелік використаних джерел:}

1. Гринь Є. Л. Ефективність управління організаційними змінами в менеджменті підприємств: теорія, методологія, практика: монографія. Харків: «Смугаста типографія», 2018. $478 \mathrm{c}$.

2. Красноруцький О. О., В Власенко Т. А., Гринь Є. Л. Науково-теоретичне обгрунтування сутності стратегічних змін на підприємстві. Економічний вісник університету. Переяслав-Хмельницький. 2018. Випуск № 38. С. 53-63.

УДК 339.13.01

Власова К. М.

аспірант кафедри економіки підприємства Київського національного університету імені Тараса Шевченка м. Київ, Україна

Філюк Г. М. доктор економічних наук, професор кафедри економіки підприємства

Київського національного університету імені Тараса Шевченка

Vlasova K. N. post-graduate student of the Department of Economics,

Taras Shevchenko National University of Kyiv

Filyuk G. M. doctor of economics, professor, head of the Department of Economics, Taras Shevchenko National University of Kyiv

\section{ВПЛИВ БАР'СРІВ НА ВИБІР СПОСОБУ ВХОДЖЕННЯ НА ЗОВНІШНІЙ РИНОК \\ THE INFLUENCE OF BARRIERS ON THE CHOICE OF THE ENTRACE METHODS ON THE EXTERNAL MARKET}

Політика неопротекціонізму, насиченість внутрішніх ринків, необхідність пошуку напрямів стратегічного розвитку, змушують національні підприємства шукати нові ринки збуту та в такий спосіб реалізувати свої потенційні можливості розвитку.

Означена проблема необхідності виходу на нові зовнішні ринки в зв'язку 3 насиченістю внутрішнього ринку та обмеженістю зовнішнього зростання шляхом розширення обсягів постачання на традиційні експортні ринки може бути вирішена завдяки пошуку можливостей виходу підприємств м'ясної промисловості на територіально нові ринки. Традиційними способами виходу підприємств на зовнішні ринки є експорт готової продукції та пряме інвестування за кордон.

Вибір способу виходу підприємства на зовнішній ринок залежить від сукупності чинників, основними із яких є стан ринку, рівень бар'єрів входу на ринок та можливості їх подолання, рівень витрат на подолання бар'єрів входу на ринок, внутрішній потенціал підприємства в частині виконання вимог зовнішнього ринку (відповідність продукції споживчим вимогам або наявність джерел інвестування за кордон). 
Дослідження залежності між рівнем бар'єрності ринку та способом виходу підприємства м'ясної промисловості на зовнішній ринок дозволило виявити, що вихід підприємства у товарній формі здійснюється на ринки, вхід на які пов'язаний з невисокими витратами на подолання бар'єрів. Високі бар'єри входу на споживчий ринок та значні витрати на їх подолання призводять до використання інвестиційних форм входу підприємств на зовнішні ринки.

Аналітичні дослідження стратегій розвитку підприємств м'ясної промисловості України дозволили виявити закономірності між бар'єрами входу на товарний зовнішній ринок та прямим інвестуванням в активи підприємств даного ринку. Резюмуючи результати досліджень було виявлено, що чим вище бар'єри входу на зовнішній споживчий ринок, тим вищою є інвестиційна активність українських підприємств м'ясної промисловості

Дослідження висотибар'єрів входження на зовнішні ринки, можливостей їх подолання та переваг діяльності на таких ринках дозволило визначити як направленість, так і спосіб такого виходу на глобальний ринок.

На сьогодні використовуються традиційні способи виходу підприємств на зовнішній ринок: експорт, спільна підприємницька діяльність, пряме інвестування.

Експорт продукції відбувається у формі прямого або опосередкованого продажу іноземному покупцеві. Нерямий експорт реалізується у формі передачі повноважень 3 експорту посередницьким компаніям, надання експортної франшизи, залучення посередницьких структур.

Спільна підприємницька діяльність передбачає створення в іноземній країні підприємства на умовах партнерства з суб'єктами потенційного зовнішнього ринку. Спільна підприємницька діяльність здійснюється на умовах надання ліцензії, виробництва за контрактом, управління за контрактом, організації підприємства спільної власності),

Пряме інвестування реалізується шляхом інвестування коштів експортера у створення виробничих потужностей на території країни імпортера. Способами інвестування $\epsilon$ придбання виробничих активів, поглинання підприємств, будівництво підприємства за кордоном, злиття з іноземним підприємством тощо.

Кожний із означених способів виходу підприємств на зовнішній ринок має свої переваги та недоліки свого використання для українських підприємств м'ясної промисловості (табл.1).

Таблиця 1

Переваги та недоліки способів виходу підприємств на зовнішній ринок

\begin{tabular}{|c|c|c|}
\hline $\begin{array}{l}\text { Способи виходу на } \\
\text { зовнішній ринок }\end{array}$ & Переваги & Недоліки \\
\hline \multicolumn{3}{|c|}{ Прямий експорт } \\
\hline $\begin{array}{l}\text { Продаж покупцеві } \\
\text { в Україні }\end{array}$ & $\begin{array}{l}\text { Продавець бере на себе } \\
\text { витрати на відвантаження } \\
\text { Покупець бере на себе всі } \\
\text { ризики доставки та продажу } \\
\text { продукції } \\
\text { споживачеві }\end{array}$ & $\begin{array}{l}\text { Відсутність інформації про процес } \\
\text { реалізації продукції }\end{array}$ \\
\hline $\begin{array}{l}\text { Пряме постачання } \\
\text { покупцеві }\end{array}$ & $\begin{array}{l}\text { Можливість отримання } \\
\text { високих результатів } \\
\text { Контроль за процесом } \\
\text { поставки та інформованість } \\
\text { про умови реалізації }\end{array}$ & $\begin{array}{l}\text { Ризик отримання великих збитків } \\
\text { Підприємство-експортер бере на себе } \\
\text { повний перелік зобов'язань від } \\
\text { дослідження та планування ринку до } \\
\text { дистрибуції на зовнішньому ринку }\end{array}$ \\
\hline \multicolumn{3}{|c|}{ Непрямий експорт } \\
\hline $\begin{array}{l}\text { Передача } \\
\text { повноважень } \\
\text { експорту } \\
\text { посередницьким }\end{array}$ & 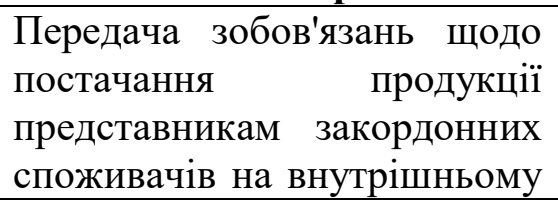 & $\begin{array}{l}\text { Відсутність інформації про вимоги } \\
\text { споживача щодо продукції, що } \\
\text { реалізується }\end{array}$ \\
\hline
\end{tabular}




\begin{tabular}{|c|c|c|}
\hline компаніям & $\begin{array}{l}\text { ринку } \\
\text { Всі витрати та ризики бере } \\
\text { на себе покупець }\end{array}$ & \\
\hline $\begin{array}{l}\text { Експортна } \\
\text { франшиза }\end{array}$ & $\begin{array}{lr}\text { Передача } & \text { процесів } \\
\text { організації збуту продукції, } \\
\text { митного очищення франчайзі }\end{array}$ & $\begin{array}{l}\text { Залежність дохідності франчайзера } \\
\text { від бізнес процесів франчайзі }\end{array}$ \\
\hline $\begin{array}{l}\text { Комерційне } \\
\text { посередництво }\end{array}$ & $\begin{array}{l}\text { Посередницька } \\
\text { бере нампанія } \\
\text { пошуку ринків збуту та } \\
\text { покупців, несе всі ризики } \\
\text { стосовно оплати та } \\
\text { транспортування. } \\
\text { Експортер має можливість } \\
\text { отримати інформацію про } \\
\text { стан конкуренції, вимоги } \\
\text { споживачів, нові можливості } \\
\text { та технології }\end{array}$ & Зниження дохідності експорту \\
\hline \multicolumn{3}{|c|}{ Спільна підприємницька діяльність } \\
\hline Ліцензування & $\begin{array}{l}\text { Можливість виробництва під } \\
\text { національною торговою } \\
\text { маркою продукції за } \\
\text { кордоном } \\
\text { Глобалізація } \\
\text { виробнової марки }\end{array}$ & $\begin{array}{l}\text { Залежність } \\
\text { виробництва по ліцективності } \\
\text { комплексу зусиль ліцензіата } \\
\text { Відсутність глобальних бід } \\
\text { виробників м'ясної продукції }\end{array}$ \\
\hline $\begin{array}{l}\text { Виробництво } \\
\text { контрактом }\end{array}$ & $\begin{array}{l}\text { Можливість виробництва на } \\
\text { замовлення іноземних } \\
\text { партнерів дозволяє знизити } \\
\text { витрати виробництва }\end{array}$ & Необхідність глобального бренду \\
\hline $\begin{array}{l}\text { Управління } \\
\text { контрактом }\end{array}$ & Передача ноу-хау управління & $\begin{array}{l}\text { Необхідність висококваліфікованого } \\
\text { штату управлінців та знань місцевих } \\
\text { стандартів управління }\end{array}$ \\
\hline $\begin{array}{l}\text { Підприємство } \\
\text { спільного } \\
\text { володіння }\end{array}$ & $\begin{array}{l}\text { Розподіл } \\
\text { виробництва }\end{array}$ & $\begin{array}{l}\text { Висока ймовірність } \\
\text { партнерів } 3 \text { причлікту } \\
\text { стандартах ведення бізнесу }\end{array}$ \\
\hline \multicolumn{3}{|c|}{ Пряме інвестування } \\
\hline $\begin{array}{l}\text { Інвестування } \\
\text { будівництво }\end{array}$ & \multirow[t]{4}{*}{$\begin{array}{l}\text { Максимальний контроль за } \\
\text { діяльністю }\end{array}$} & \multirow{4}{*}{$\begin{array}{l}\text { Складна процедура виходу з ринку } \\
\text { Всі } \quad \text { ризики } \\
\text { підприємство бере на себе }\end{array}$} \\
\hline Приєднання & & \\
\hline Поглинання & & \\
\hline Злиття & & \\
\hline
\end{tabular}

При виборі способу виходу підприємств м'ясної промисловості на нові зовнішні ринки враховуються наступні концепти:

1) експорт продукції має більшу мобільність 3 огляду на швидкість зміни партнерського ринку;

2) експорт незначними обсягами дозволяє вивчити вимоги ринку до даного виду продукції;

3) інвестиції в будь-якій формі мають високий ризик майбутньої ефективності. 
студентка групи ПФм-51

Тернопільський національний технічний університет імені Івана Пулюя,

м. Тернопіль, Україна

Науковий керівник: Панухник Олена

д.е.н., професор,

завідувач кафедри економіки та фінансів,

Тернопільський національний технічний університет ім.Івана Пулюя,

м. Тернопіль, Україна

Antonina Gladka

student of group PFm-51

Ternopil Ivan Puluj National Technical University

Ternopil, Ukraine

Scientific supervisor: Panukhnyk Olena

D.Sc. (Econ.) Professor,

Head of the Department of Economics and Finance,

Ternopil Ivan Puluj National Technical University,

Ternopil, Ukraine

\section{ФІНАНСОВЕ ЗАБЕЗПЕЧЕННЯ ДІЯЛЬНОСТІ СУБ СКТІВ МАЛОГО ТА СЕРЕДНЬОГО БІЗНЕСУ \\ FINANCIAL PROVISION FOR THE ACTIVITY OF THE SMALL AND MEDIUM BUSINESS}

Підприємство є відкритою економічної системою, яка взаємодіє із зовнішнім середовищем не лише на етапі організації бізнесу, а й в моменти вирішення проблеми вибору джерела фінансування.

Зрозуміло, що ідеальним є варіант самофінансування, за якого власних коштів, які залишаються після вирахування усіх витрат у розпорядженні підприємства, достатньо для розширення чи вдосконалення діяльності.

Діяльність суб єктів малого та середнього бізнесу характеризується тим, що майже у кожного такого підприємства в певний момент часу виникає дилема щодо вибору оптимального джерела та обсягу фінансованих ресурсів. Найбільш поширений варіантом зовнішнього джерела фінансових ресурсів залишається банківський сектор, який пропонує суб єктам господарювання досить широкий спектр кредитних послуг.

Перед прийняттям рішення щодо зовнішнього фінансування, підприємству необхідно провести деталізований моніторинг та аналіз діяльності з метою пошуку внутрішніх джерел фінансування та оптимізації найбільш витратних або незбалансованих у фінансовому сенсі бізнес-процесів.

На рівні суб'єктів господарювання це передбачає удосконалення механізмів управління капіталом за рахунок зниження витрат виробництва і реалізації, на формування, розподіл, використання капіталу; підвищення ефективності використання ресурсів; оптимізації структури і складу позаоборотних і оборотних активів, власного та позикового капіталу; ефективного управління дебіторською та кредиторською заборгованістю; прискорення оборотності активів; удосконалення системи управління грошовими потоками; вибору ефективної амортизаційної та дивідендної політики; визначення і дотримання оптимального співвідношення «ризик-доходність»; зростання якості та асортименту продукції, іiі інноваційності; зростання позитивного іміджу підприємства та іiі ділової репутації [1]. 
Держава не повинна залишатися осторонь процесів фінансової підтримки та підприємницького стимулювання суб єктів господарювання, особливо малого та середнього бізнесу як драйверу вітчизняної економіки.

Основними критеріями при виборі механізмів та інструментів фінансової підтримки у світовій практиці є: податковий механізм, порядок та організація відкриття та ведення бізнесу; співвідношення прямих та непрямих форм фінансової допомоги; фінансове забезпечення залежно від етапу життєвого циклу; вибір пріоритетних напрямів діяльності та особливих сфер підтримки, які підлягають бюджетному фінансуванню тощо [2].

Отже, поєднання та доступність таких способів фінансування суб єктів малого та середнього бізнесу як самофінансування, фінансування державою, банківське кредитування, лізинг, факторинг, венчурне фінансування, краудфандинг будуть визначати фінансову поведінку підприємства.

\section{Перелік використаних джерел:}

1. Ломачинська I. А. Формування джерел фінансового забезпечення розвитку суб'єктів малого підприємництва [Електронний ресурс] / I. А. Ломачинська // Вісник Одеського національного університету. Економіка. - 2012. - Т. 17, Вип. 3-4. - С. 37-43. Режим доступу: http://nbuv.gov.ua/UJRN/Vonu_econ_2012_17_3-4_7

2. Варналій 3. С. Моделювання системи фінінансового забезпечення розвитку малих підприємств / Варналій 3. С. // «Економіка. Менеджмент. Бізнес». -2017. -С. 144 -151

УДК 336

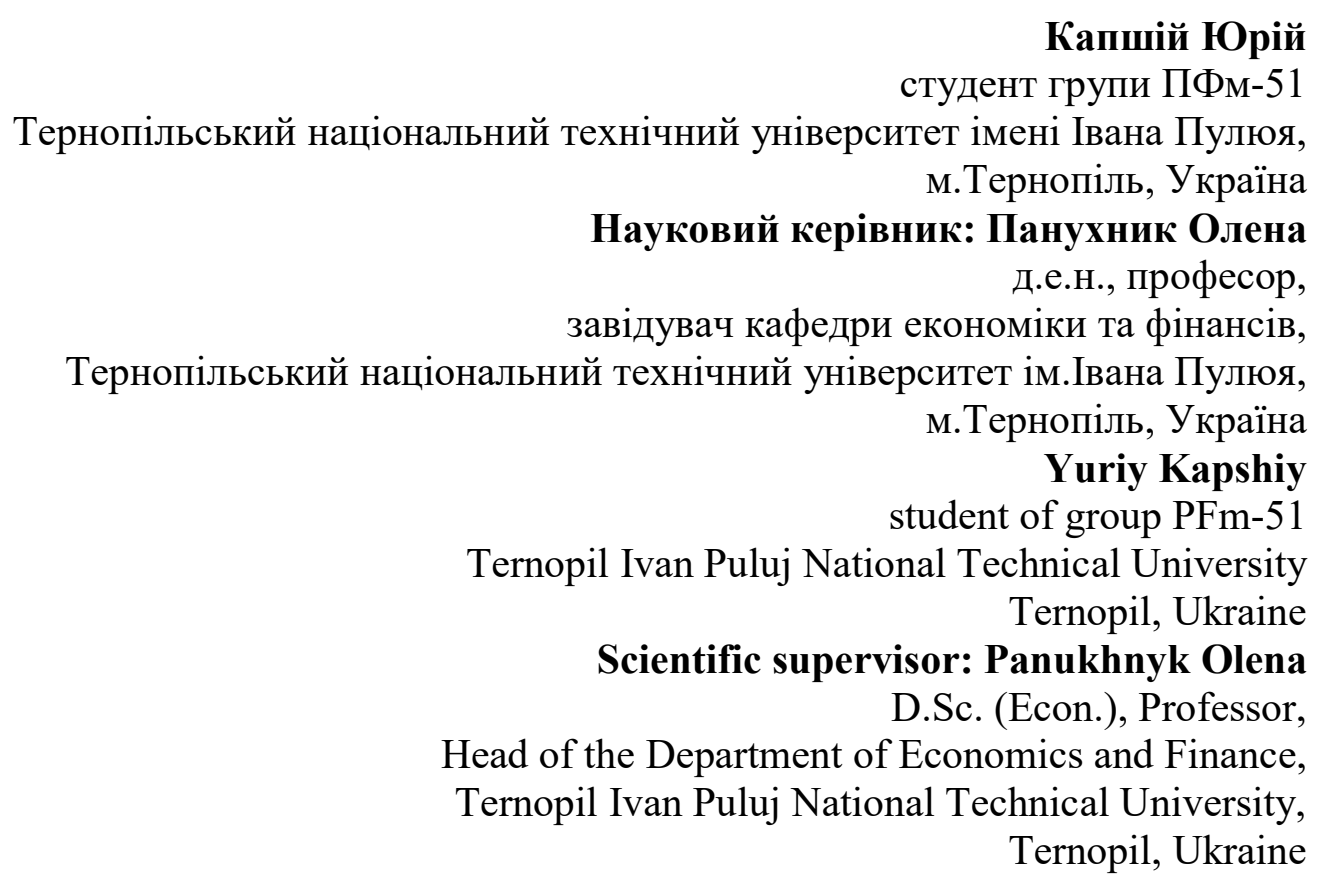

\section{ОСОБЛИВОСТІ АНАЛІЗУ ЕКОНОМІЧНОГО ПОТЕНЦАЛУ СУБ`ЄКТА ПІДПРИЕМНИЦТВА \\ FEATURES OF ANALYSIS OF ENTERPRISES SUBJECTS ECONOMIC POTENTIAL}

Стан суб `кта підприємництва може бути оцінений як шляхом деталізованого аналізу фінансової та управлінської звітності, внутрішньої документації, аналізу ринкової кон'юнктури, так і шляхом розрахунку певного інтегрального показника, який буде містити основні індикатори, що становлять базу розрахунку та порівняння. 
Питанням пошуку та побудови універсального інтегрального показника оцінки економічного потенціалу присвячено досить багато праць як вітчизняних так і закордонних дослідників, проте цілком очевидно, що єдиної методики розрахунку виробити не вдасться, адже підприємства різняться між собою не тільки галузевою приналежністю, що накладає суттєвий відбиток на особливості проведення аналізу, а й вагомістю окремих компонент інтегрального показника при розрахунку кінцевої оцінки.

Існуючі та поширені методики оцінювання поряд із своїми перевагами (наприклад, простота отримання даних чи проведення розрахунків), можуть виявитися досить дефективними.

На сьогоднішній день існує чимало методик оцінювання потенціалу підприємства, в основі яких лежать різноманітні математичні, графічно-аналітичні моделі, матричні, логічні та лінгвістичні методи тощо [1, с. 90-92].

Підходи, побудовані на згортці показників, що характеризують окремі аспекти діяльності підприємства, виявилися надто залежними від рішень експерта і не стабільними до варіацій у вихідних даних. Інші класичні методи діагностування - кластерний аналіз, дерева рішень, імітаційне моделювання та байєсівські мережі - виявилися занадто чутливими до повноти і чіткості вихідних даних [2].

Проте, на наш погляд, досить успішним у цьому напрямку наукових досліджень $\epsilon$ Г. О. Закаблук, яка вважає, що «...в основі інтегральної оцінки лежить формування системи показників, що характеризують досліджуваний показник та $\epsilon$ ефективним механізмом аналізу будь-якої діяльності. Інтегральний показник фінансово-економічного стану промислового підприємства відображає поточний стан та розвиток його діяльності на основісистеми фінансових показників. До таких показників відносяться такі групи: показники майнового стану, ліквідності, платоспроможності, ділової активності, рентабельності тощо» [3]. Закаблук Г. О. інтегральне оцінювання фінансово-економічного стану підприємства пропонує проводити за наступними етапами:

1. Формування масиву вихідних даних

2. Формування системи фінансових показників, що характеризують діяльність підприємства та їх розрахунок

3. Визначення групових інтегральних показників

4. Визначення інтегрального показника фінансово-економічного стану підприємства

На нашу думку, такий підхід є досить вдалим, адже дозволяє враховувати достатньо великий масив даних та зводити його до однієї системи виміру. Цю тезу повністю підтверджує Шталь Т. В. [4], адже «...головна складність аналізу і оцінки потенціалу полягає в тому, що всі його елементи функціонують одночасно і в сукупності. Тому необхідно проводити саме комплексну інтегровану його оцінку».

Отже, аналіз економічного потенціалу суб єкта підприємництва повинен проводитися на принципах моніторингу, тобто безперервності, а економетричне моделювання цього процесу дасть змогу вчасно виявити «вузькі місця» та відкорегувати відхилення від сформованих цілей.

\section{Перелік використаних джерел:}

1. Макарова Г. С. Форми оцінки економічного потенціалу підприємства / Г. С. Макарова // Економіка підприємства та управління виробництвом. - 2011. - № 5. C. 89-92.

2. Бідюк П. І. Інтегральне оцінювання підприємств машинобудування при їх реструктуризації / П. І. Бідюк, О. С. Омельченко, В. Ю. Любар // Бізнес Інформ. - 2014. - № 6. - С. 262-269. - Режим доступу: http://nbuv.gov.ua/UJRN/binf_2014_6_47

3. Закаблук Г. О. дослідження динаміки показників фінансово-економічного стану промислових підприємств на засадах інтегрального оцінювання / Г. О. Закаблук // Інвестиції: практика та досвід [Текст]. - 2018. - № 12., с. 36-41 
4. Шталь Т. В. Комплексна оцінка ресурсного потенціалу підприємств роздрібної торгівлі: автореф. дис...канд. екон. наук: 08.07.05 / Т. В. Шталь. - Х., 2006. - 18 с.

УДК 336

Кобильняк Ганна
студентка групи ППмз-51

Тернопільський національний технічний університет імені Івана Пулюя

м. Тернопіль, Україна

Науковий керівник: Панухник Олена

д.е.н., професор

завідувач кафедри економіки та фінансів

Тернопільський національний технічний університет ім. Івана Пулюя

м. Тернопіль, Україна

Hanna Kobilnyak

student group ППмз-51

Ternopil Ivan Puluj National Technical University

Ternopil, Ukraine

Scientific supervisor: Panukhnyk Olena

D.Sc. (Econ.), Professor

Head of the Department of Economics and Finance

Ternopil Ivan Puluj National Technical University

Ternopil, Ukraine

\section{РОЗВИТОК ПІДПРИЕМНИЦТВА В АГРАРНОМУ СЕКТОРІ ЕКОНОМІКИ УКРАЇНИ \\ DEVELOPMENT OF ENTREPRENEURSHIP IN THE AGRICULTURAL SECTOR UKRAINE}

Підприємництво в аграрній сфері - складне та багатогранне явище, яке набуває різних форм. Ця різноманітність дозволяє організовувати підприємницьку діяльність конкретною особою на конкретній території таким чином, щоб якнайкраще використовувати ресурсну базу та отримувати максимальну вигоду. Наразі, з розвитком аграрного підприємництва, держава пов'язує проведення структурних змін на селі, забезпечення впровадження реформ в економіці та вирішення соціальних проблем українського села.

Розвиток підприємництва - це шлях до насичення ринку товарами і послугами, подолання галузевого і регіонального монополізму, розширення конкуренції, впровадження досягнень науково-технічного прогресу, підвищення експортного потенціалу.

Найпоширенішими формами підприємств на селі, відповідно до Указу Президента України «Про невідкладні заходи щодо прискорення реформування аграрного сектора економіки», $€$ : приватні (приватноорендні) підприємства, фермерські господарства, господарські товариства, сільськогосподарські кооперативи, а також інші суб'єкти господарювання, засновані на приватній власності (приватні формування) [1].

На заваді широкому розвитку підприємництва в аграрній сфері України стоять певні складності. Серед них: відсутність достатніх грошових заощаджень (первинного капіталу) працівників сфери АПК - потенційних підприємців; малооб'єктної виробничої і обслуговуючої матеріальнотехнічної бази; належного правового захисту і певних юридичних гарантій підприємців з питань власності, розпорядження майном, отримання і розподілу доходів

На сьогодні з розвитком аграрного підприємництва держава пов'язує проведення структурних змін на селі, забезпечення впровадження реформ в економіці та вирішення соціальних проблем українського села. Адже задекларований Україною принцип пріоритетності агропромислового комплексу не знаходить практичного втілення. Непослідовність дій, недостатній рівень фінансового забезпечення та відсутність належного 
реагування на результати державного контролю в системі управління земельними відносинами призводять до погіршення соціально-економічних показників розвитку сільського господарства [2].

Отже, внаслідок відсутності виваженої системи державного управління в аграрній сфері нагромаджується комплекс проблем, які полягають у:

- низькій ефективності сільськогосподарського виробництва в Україні, порівняно 3 іншими країнами світу;

- загостренні продовольчої проблеми, через незбалансоване споживання продуктів харчування населенням, низький рівень споживання продуктів тваринного походження та імпортозалежність за окремими групами продовольства, передусім по рибі і рибопродуктах, плодах, ягодах та винограду;

- зниженні рівня зайнятості на селі та відсутності якісних робочих місць;

- відставанні доходів сільського населення від доходів міських жителів та зростанні трудової міграції;

- зменшенні чисельності сільського населення;

- погіршенні соціальної інфраструктури на селі; - виснаженні грунтів, погіршенні екології агротериторій..

Вирішення цих проблем завдяки розвиткові малого підприємництва на селі дасть змогу пом'якшити проблему зайнятості у сільській місцевості, сприятиме іншим позитивним соціально-економічним перетворенням на селі, забезпечить зростання обсягів вітчизняного агровиробництва [3].

Отже, без сумніву, створенню умов підвищення ефективності функціонування аграрного підприємництва повинні сприяти важелі державної політики. При цьому державна підтримка повинна носити стимулюючий характер (розумні дотації, пільгові режими оподаткування, кредитування, інвестування, страхування та ін.), але без заохочення утриманства. Разом 3 тим держава повинна посилити контроль за ефективністю господарювання, зокрема платіжною дисципліною, процесами ціноутворення, ступенем відкритості ринку.

Висновки. Підприємництво є одним із основних чинників формування і розвитку соціально орієнтованої ринкової економіки. Без створення інституційних, а також економічних, організаційних та соціальних передумов для підприємництва аграрна економіка України неспроможна функціонувати у конкурентному світі. Сільське підприємництво забезпечує максимальну реалізацію професійного i творчого потенціалу селянина, ефективне використання матеріальних факторів виробництва і робочої сили.

Найбільшими перешкодами для здійснення підприємницької діяльності в агарній сфері Україні на сьогодні $\epsilon$ політична нестабільність, корупція, важкий доступ до фінансування, неефективне податкове регулювання, нестабільність уряду та можливість переворотів, неефективність державного управління, високий рівень інфляції, високі ставки оподаткування. Вважаємо, що найбільш раціонально функції підтримки і контролю підприємництва поєднують державні комплексні регіональні програми розвитку підприємництва.

\section{Перелік використаних джерел:}

1. Організаційно-економічні інструменти державної аграрної політики в Україні: аналіт. доп. / В. М. Русан, О. В. Собкевич, А. Д. Юрченко. - К. : Вид-во НІСД, 2012. - 88 с.

2. Державний комітет статистики України [Електронний ресурс]. - Режим доступу: www.ukrstat.gov.ua.

3. Лещик І. Б. Організаційно-економічні трансформації в аграрному секторі економіки / І. Б. Лещик, Г. І. Пиріг // Сталий розвиток економіки. - 2013. - № 3. - С. $327-$ 331. 
Ковальчук Руслан-Петро студент групи ППм-51

Тернопільський національний технічний університет імені Івана Пулюя

м. Тернопіль, Україна

Ruslan-Petro Kovalchuk student of the group ППм-51

Ternopil Ivan Puluj National Technical University Ternopil, Ukraine

Науковий керівник: Мариненко Наталія професор кафедри економіки та фінансів,

Тернопільський національний технічний університет імені Івана Пулюя, м. Тернопіль, Україна

Scientific supervisor: Nataliia Marynenko

Professor of the Department of Economics and Finance

Ternopil Ivan Puluj National Technical University

Ternopil, Ukraine

\section{ЯКІСТЬ ТОВАРУ ЯК ФАКТОР УСПІШНОГО ФУНКЦІОНУВАННЯ СУБ'СКТІВ ГОСПОДАРЮВАННЯ \\ QUALITY OF THE PRODUCT AS FACTOR OF BUSINESS ENTITIES SUCCESSFUL FUNCTIONING}

У сучасних умовах здійснення економічної діяльності, якість продукції відіграє одну з найголовніших ролей в ефективному функціонуванні підприємства. Для покращення конкурентних позицій на ринку, перспективи довготривалого функціонування на ньому, завоювання лояльності споживачів підприємство повинне забезпечити високий рівень якості продукції, яку виробляє.

Багато компаній використовують програми загального управління якістю (Total Quality Management, TQM), намагаючись постійно покращувати якість як самого продукту, так і усіх етапів його виготовлення. На сьогоднішній день виробники розцінюють якість як інвестицію, а їі покращення - як один із ключових факторів успіху.

Якість - це сукупність властивостей та характеристик продукції і послуг, які надають їм властивість задовольняти обумовлені чи запропоновані потреби (стандарт ISO 8402:1994, c. 11).

Стандарти серії ISO 9000 встановили єдиний, визнаний у світі підхід до договірних умов з оцінки систем якості та одночасно регламентували відносини між виробниками $\mathrm{i}$ споживачами продукції [1, с. 12].

Якість є найважливішою для споживачів характеристикою товару. Це поняття включає такі характеристики як надійність, безпека для здоров'я, зручність в експлуатації, відповідність виробу його функціональному призначенню, сучасним науково-технічним стандартам, екологічним вимогам, якість і рівень післяпродажного обслуговування. Технікоекономічне поняття якості охоплює тільки ті властивості товару, що роблять його корисним, здатним задовольняти ті потреби, заради яких він купувався. Тому з економічної точки зору, якість - це сукупність споживчих властивостей товару (послуги), що дозволяють використовувати його (iх) за призначенням [2, с. 65-66].

Впровадження міжнародних стандартів дає змогу виробникові не лише підвищити якість своїх товарів до рівня міжнародних вимог, але й забезпечує перебудову виробництва, його організацію, технологію, систему управління до рівня розвинених країн. Наявність сертифіката відповідності якості полегшить доступ українського виробника до міжнародних 
ринків, що прописано в Угоді про асоціацію між Україною та Європейським Союзом при входженні українських виробників на його ринки.

\section{Перелік використаних джерел}

1. Зіміна, Г. К., 2008. Стандартизація системи управління якістю, згідно стандартів серії ISO 9000:2000 (у схемах): Навч.-практ. посіб. Школа адм. управління Зіміної, 256 с.

2. Юрій Журик, 2014. Критерії якості продукції (товарів, робіт, послуг) у форматі відносин економічної конкуренції. Юридична Україна. Економіка і право, № 6, с. 65-70.

Корнієцький Олександр

доктор економічних наук, доцент, професор кафедри організації виробництва, бізнесу та менеджменту

Харківський національний технічний університет сільського господарства імені Петра Василенка

м. Харків, Україна

Oleksandr Korniyetskyy

doctor of economics, associate professor,

Department of organization of production, business and management, Kharkiv Petro Vasylenko National Technical University of Agriculture,

Kharkiv, Ukraine

\section{МОТИВАЦИЙНІ ПРИНЦИПИ РЕГІОНАЛЬНОГО УПРАВЛІННЯ СІЛЬСЬКИХ ТЕРИТОРІЙ \\ MOTIVATING PRINCIPLES OF REGIONAL GOVERNMENT OF AGRICULTURAL TERRITORIES}

Мотивація, розглянута як процес, що теоретично може бути представлений у вигляді шести наступних стадій. Такий розгляд процесу носить умовний характер, так як в реальному житті немає настільки чіткого розмежування стадій і немає відособлених процесів мотивації та децентралізації розвитку сільських територій. Тому даний процес включає наступні стадії (рис.1):

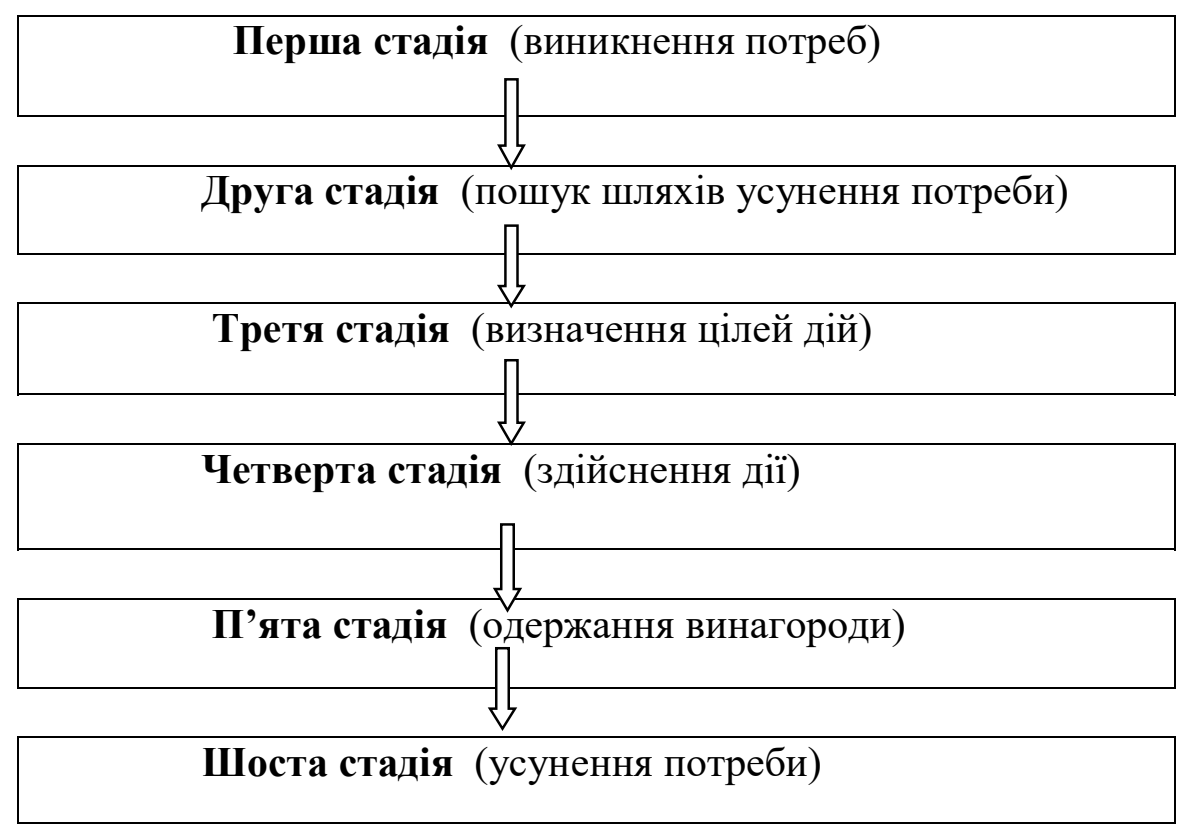

Рис. 1. Стадії здійснення мотиваційних процесів 
*- складено автором

1) перша стадія - виникнення потреб ( потреба проявляється в тому, що людина починає відчувати, що йому чогось не вистачає. Потреби можуть бути самими різними:фізіологічні;психологічні;соціальні). зробити).

2) друга стадія - пошук шляхів усунення потреби (виникає необхідність щось

3) третя стадія - визначення цілей дії (на даній стадії повинні бути знайдені відповіді на такі питання: усунути потребу; отримати бажане).

4) четверта стадія - здійснення дії (процес роботи робить зворотний вплив на мотивацію, то на цій стадії може відбуватися коригування цілей).

5) п'ята стадія - одержання винагороди за здійснені дії (на даній стадії з'ясовується, наскільки виконання дій дало бажаний результат).

6) шоста стадія - усунення потреби.

Забезпечення більш високого ступеня гнучкості регіональних і місцевих економік може бути досягнуто тільки за рахунок зміни мотиваційних принципів регіонального управління, особливо це значимо для сільського господарства та сільських територій. Сама галузь сільськогосподарського виробництва спочатку завжди була, та є органічно пов'язаної 3 територією і людьми, що проживають на цій території, вона безпосередньо інтегрується 3 усіма галузями економіки, такими як харчова і легка, комбікормова та інші промисловості. В силу історично сформованою традицією на сільськогосподарські підприємства покладено тягар житлово-комунального господарства, побутового обслуговування, торгівлі та громадського харчування. Звідси можна зробити чіткий висновок про те, що для розвитку галузі сільськогосподарського виробництва необхідно створити умови життя людей на даній території, що відповідають сучасним вимогам життя суспільства, керуючись стратегічним баченням пріоритетності галузі в рамках гармонійного розвитку людини і продовольчої безпеки. Рішення проблем сталого розвитку економіки та підвищення добробуту населення багато в чому визначається розвитком сільських територій (сільській місцевості)[1]. У нашій країні протягом багатьох десятиліть основним шляхом розвитку сільських територій був вузькогалузевий аграрний підхід, в тому числі на територіях 3 обмеженими аграрними потенціалами. Це призвело до однобокого аграрному розвитку сільських територій, часто нераціонального розміщення на них продуктивних сил, нерозвиненості соціально-побутової інфраструктури і інших серйозних проблем зв'язаних з децентралізацією.

Розвиток будь-якої території підпорядковується поєднанню двох принципів: функціональної відповідності та позиційному. Перший має на увазі використання земель в залежності від їх внутрішніх, природних властивостей і ресурсної цінності. Другий вимагає брати до уваги просторове положення земель щодо інших природних i антропогенних об'єктів, а в більш широкому сенсі - соціально-економічну обстановку[2].

У міжнародній практиці також зустрічається наступний поділ сільських регіонів:

- економічно-інтегровані регіони;

- середні або перехідні регіони;

- віддалені регіони.

Несприятливі природні умови виробництва i віддаленість від ринків збуту характеризують несприятливі умови для ведення сільського господарства. Таким чином, віддалені регіони пред'являють найбільші вимоги до політики розвитку сільських регіонів. Першочерговою метою тут $є$ знаходження відповідного рівності між економічним наданням послуг, досягненням прийнятного стандарту життя, економічної ефективності та довгострокового менеджменту навколишнього середовища. Створення мотиваційних умов для сталого розвитку сільських територій є однією 3 найважливіших стратегічних цілей державної політики, що забезпечує ефективне використання всього потенціалу економіки країни. Аграрний сектор, який займає домінуюче становище в економіці села, є багатофункціональним і не тільки виробляє товарну продукцію, але також 
забезпечує відтворення суспільно значущих цінностей, які не завжди піддаються кількісній або вартісній оцінці.

\title{
Перелік використаних джерел:
}

1. Заблоцькій Б. Ф. РПС України. Національна мікроекономіка. К.: Академвидав, 2003. - $368 \mathrm{c}$.

2. Сазонець І. Л., Джінджоян В. В. Чубар О. О. Розміщення продуктивних сил. К.: ЦНЛ, 2006. - 320 с.

3. Андрійчук В. Г. Економіка аграрних підприємств : підручник / В. Г. Андрійчук. - 2-е вид., доп. і перероб. - К. : КНЕУ, 2002. - 624 с.

4. Козаченко Г. В. Управління затратами підприємства: монографія / Г. В. Козаченко, Ю. С. Погорелов, Л. Ю. Хлапьонов. - Київ: Лібра, 2007. - 320 с.

5. Волков О. I. Інноваційний розвиток промисловості України: навч. посіб. / О. І. Волков, М. П. Денисенко, А. П. Гречан ; за ред. О. І. Волков, М. П. Денисенко. - К.: КНT, 2006. -648 с.

\section{УДК 65.016}

\author{
Легеза Назар \\ Аспірант ФММ \\ НТУУ «КПІ ім. Ігоря Сікрського» \\ Науковий керівник: Мартиненко Василь \\ професор д.е.н. \\ НТУУ «КПІ ім. Ігоря Сікрського» \\ Nazar Legeza \\ Postgraduate student of FMM \\ NTUU "KPI them. Igor Sikrsky » \\ Supervisor: Vasyl Martynenko \\ Prof. D of Science (Economic) \\ NTUU "KPI them. Igor Sikrsky»
}

\section{ТЕОРЕТИЧНІ АСПЕКТИ РОЗВИТКУ ПІДПРИЕМСТВА THEORETICAL ASPECTS OF DEVELOPMENT OF THE ENTERPRISE}

В умовах конкурентної боротьби підприємства мають звертати увагу на забезпечення розвитку підприємства, щоб не втратити ринкові позиції та залишитись на плаву. На даний момент в економічній науці існує багато трактувань поняття «розвиток підприємства» але суперечливість деяких з них потребує проведення поглибленого аналізу тлумачень даного поняття.

Термін «розвиток підприємства» має неоднозначне тлумачення, тому варто розпочати 3 трактування терміну «розвиток». Наприклад Філософські науки пояснюють розвиток, специфічним процесом змін, в результаті якого виникає щось якісно нове, поступальний процес зростання від нижчого до вищого, від складного до простого. [1] В свою чергу на думку О. Л. Гапоненко, А. П. Пакрухина, розвиток - це рух вперед, формування нових якостей, становлення нових характеристик об'єкта, його еволюція, покращення, удосконалювання, також ріст і розширення. [2]. Варто також зазначити, що в Академічному тлумачному словнику української мови розвиток визначено, що це процес, внаслідок якого відбувається зміна якості чого-небудь, перехід від одного якісного стану до іншого [3]. Саме О. Л. Гапоненко, А. П. Пакрухіна найточніше визначають поняття «розвиток» акумулюючи в трактуванні основні риси які притаманні розвитку як підприємств так і інших суб'єктів.

Тлумачення терміну «розвиток підприємства» в свою чергу базується на трактуваннях розвитку як процесу. Так наприклад Ю.А. Плугіна вказує що розвиток підприємства це якісні перетворення в його діяльності за рахунок змін кількісних i 
структурних характеристик техніко-технологічних, організаційно-комунікаційних, фінансово-економічних ресурсів на основі ефективного використання інтелектуальнокадрових ресурсів та інформаційних технологій. [4] Е. М. Коротков використовує наступне трактування даного поняття, розвиток підприємства це сукупність змін, які ведуть до появи нової якості та зміцнення життєвості системи, іiі здатність чинити опір руйнівним силам зовнішнього середовища [5].

Але найкраще поняття «розвиток підприємства» розкриває Ю. С. Погорєлов «...Безупинний процес, що відбувається за штучно встановленою або природною програмою як зміна станів підприємства, кожен з яких є якісно іншим за попередній, через що у підприємства як у більш складної системи виникають та можуть бути реалізовані нові можливості, нові властивості, якості та характерні риси, які сприяють здатності підприємства виконувати нові функції, вирішувати принципово інші завдання, що зміцнює його позиціонування в зовнішньому середовищі і підвищує здатність протидіяти його негативним впливам.» [6].

Отже було визначено трактування поняття «розвиток», саме О. Л. Гапоненко, А. П. Пакрухіна найточніше визначають дане поняття «це рух вперед, формування нових рис, становлення нових структурних характеристик об'єкта, його еволюція, поліпшення, удосконалювання, прогрес, а також ріст і розширення». Найбільш чітко тлумачення поняття «розвиток підприємства», наводить Ю. С. Погорєлов. За існуючого безперервного процесу змін зовнішнього середовища, необхідно продовжувати виявляти нові фактори, що характеризуватимуть розвиток підприємства. Результати даного дослідження можуть використовуватись студентам магістрами та аспірантами для поглиблення вивчення понять «розвиток» та «економічний розвиток».

\section{Перелік використаних джерел:}

1. Філософський словник: За ред. В. І. Шинкарука// 2-ге вид. - К.: Голов. ред. УPE, 1986. - $800 \mathrm{c}$

2. Раєвнєва О. В. Управління розвитком підприємства: методологія, механізми, моделі : монографія / О. В. Раєвнєва. - Харків, 2006. - 496 с.

3. Розвиток : академічний тлумачний словник української мови (1970-1980). [Електронний ресурс]. - Доступний з http://www.sum.in.ua/s/rozvytok.

4. Плугіна Ю. А. Інтелектуальний розвиток: сутність поняття / Ю. А. Плугіна // Вісник економіки транспорту і промисловості. - Харків, 2011. - № 36. - С. 193-196.

5. Коротков Э. М. Концепция менеджмента / Э. М. Коротков. - М. : Изд-во "Дека", 1997. - 304 с

6. Погорєлов Ю.С. Категорія розвитку та ऑï експлейнарний базис / Ю. С. Погорєлов // Теоретичні та прикладні питання економіки. - К., 2012. - Вип. 27, т. 1. C. 30-34. 
Радинський Сергій

кандидат економічних наук, доцент доцент кафедри економіки та фінансів Тернопільський національний технічний університет імені Івана Пулюя м. Тернопіль, Україна

Дьолог Івета студентка групи ПФмз-51 Тернопільський національний технічний університет імені Івана Пулюя м. Тернопіль, Україна

Radynskiy Serghiy $\mathrm{PhD}$ (Economics) Docent, Assosiate Professor of Economics and Finance Department Ternopil Ivan Puluj National Technical University Ternopil, Ukraine

Dyolog Iveta student group PFmz-51

Ternopil Ivan Puluj National Technical University Ternopil, Ukraine

\section{МЕХАНІЗМИ УПРАВЛІННЯ МАЙНОМ ПІДПРИСМСТВА MECHANISMS OF MANAGEMENT OF THE PROPERTY OF THE ENTERPRISE}

Сьогодні одним 3 найбільш актуальних завдань, що стоять перед сучасним підприємством, яке має в своєму розпорядженні досить складне та дороге в обслуговуванні обладнання, $\epsilon$ необхідність забезпечення його безпеки та одночасно економічної ефективної роботи. Важливим моментом при вирішенні цього завдання стає впровадження систем планування та управління виробничими фондами й активами підприємства, що складають невід'ємну частину виробничого процесу та дозволяють збільшувати виробничу потужність підприємства за рахунок використання сучасних інформаційних технологій, оновлюючи наявне або купляючи нове обладнання. Управління майном виступає визначальним i стратегічно важливим чинником підтримання й укріплення майнового стану підприємства.

Для забезпечення ефективної діяльності підприємства, формування його майна повинно носити цілеспрямований характер. Основною метою формування активів підприємства $є$ виявлення та задоволення потреби в окремих їх видах для забезпечення технологічного процесу, а також оптимізації складу щодо забезпечення умов ефективної господарської діяльності. При формуванні активів підприємства необхідно враховувати:

1. Перспективи розвитку діяльності підприємства та можливі зміни щодо його об'єктів. Тому сформовані активи підприємства повинні мати певний резервний потенціал, який би забезпечував можливості приросту обсягів господарювання та зміни об'єктів діяльності в майбутньому періоді.

2. Забезпечення оптимального співвідношення обсягів та структури активів, обсягів та структури об'єктів господарської діяльності. Таке співвідношення повинно забезпечуватись через розробку бізнес-плану щодо визначення потреби в окремих видах активів.

3. Ефективність використання активів, що характеризує зв'язок між їх кількістю і обсягом отриманого чистого доходу у результаті використання об'єктів майна. Збільшення обсягів господарювання при даному обсязі активів означає підвищення ефективності їх використання. I навпаки, зменшення обсягів чистого доходу, який одержують із даної величини залучених активів, свідчить про зменшення ефективності їх використання.

Ефективне використання активів передбачає досягнення [3, с. 161-162]: а) повної зайнятості активів; б) повного обсягу об’єктів господарської діяльності. Повна зайнятість означає використання усіх наявних для господарювання активів. У підприємства не повинно 
бути активів, які не використовуються.

Однак використання усіх наявних активів не гарантує певного рівня ефективності. Слід ще забезпечити повний обсяг господарської діяльності, що означає використання активів так, щоб вони найповніше задовольняли потреби. Якщо підприємство не досягло повного обсягу господарювання, то кажуть, що активи недовикористовуються. Повний обсяг господарювання формується за наявності двох видів ефективності — розподільної та виробничої.

Розподільна ефективність означає, що активи залучають до виробництва саме тих об'єктів господарювання, які найбажаніші й найпотрібніші для підприємства. Повний обсяг виробництва передбачає досягнення виробничої ефективності, тобто використання найсучаснішої технології, яка забезпечує максимальну віддачу від активів та виробництва об’єктів господарювання з найнижчими витратами.

В процесі формування активів підприємства здійснюють оптимізацію їх співвідношення щодо [1, с.207-208]:

- сукупних розмірів необоротних і оборотних активів;

- активних (безпосередньо задіяних в технологічному процесі) i пасивних (обслуговують технологічний процес) необоротних активів;

- об’єктів оборотних активів (запасів, дебіторської заборгованості і грошових коштів).

Водночас, при управлінні активами підприємство ставить завдання щодо [2]: отримання найбільшого прибутку за найменшого ризику; забезпечення правильної структури; своєчасного отримання коштів; збільшення обсягів реалізації; раціональної інвестиційної стратегії; оптимізації залучення фінансових ресурсів для розміщення в активах.

При здійсненні діяльності, активи підприємства під впливом господарських операцій безпосередньо змінюються як за величиною, так і за складом. За характером впливу на активи підприємства господарські операції можна поділити на 3 типи.

Перший тип. Відбувається переміщення та зміна структури наявних активів, загальна сума їх не змінюється.

Другий тип. Збільшуються активи та фінансові ресурси підприємства на рівновелику суму.

Третій тип. Зменшуються активи і фінансові ресурси на рівновелику суму.

Величину активів збільшують вклади і доходи, а зменшують вилучення і витрати. Вклади і вилучення здійснюють безпосередньо власники щодо власного капіталу та учасники діяльності підприємства, що формують його зобов'язання, а доходи і витрати відбуваються в процесі господарської діяльності. Якщо доходи перевищують витрати, то різниця називається чистим прибутком, який збільшує фінансові ресурси і активи в частині власного капіталу. А якщо витрати перевищують доходи, то різниця називається чистим збитком, який зменшує фінансові ресурси і активи в частині власного капіталу.

Можна виділити такі принципи формування майна [3, с.163]. 1. Врахування найближчих перспектив розвитку операційної діяльності і форм iii диверсифікації. 2.Забезпечення відповідності обсягу і структури майна обсягу і структурі виробництва та збуту продукції. 3.Забезпечення оптимального складу майна 3 позиції ефективності господарської діяльності. 4.Забезпечення умов прискорення обороту майна в процесі його використання. 5.Вибір найбільш прогресивних видів майна 3 позиції забезпечення росту ринкової вартості підприємства.

Таким чином, управління майном підприємства (операційними активами) являє собою систему принципів і методів розробки та реалізації управлінських рішень, пов'язаних з їх формуванням та ефективним використанням в операційній діяльності підприємства й організацією їх обороту. Якісно та правильно сформована структура майна забезпечує конкурентоздатність діяльності підприємства, високий рівень його фінансової стійкості і рентабельності, проте вимагає складної аналітичної роботи через неточний характер 
фінансового планування та прогнозування на підприємстві, що на практиці $є$ важко досяжним.

\section{Перелік використаних джерел:}

1. Олійник Л.В. Сучасні підходи до ефективного управління ресурсами та активами підприємства / Л. В. Олійник // Вісник Хмельницького національного університету. Економічні науки. - 2012. - №4, Т.2. - С. 206-209.

2. Ротар Д. А. Ключові особливості стратегічного управління активами підприємств та шляхи його удосконалення / Д. Ротар // Економічні науки. - 3. Фінансові відносини. [Електронний ресурс]. - Режим доступу: http://www.rusnauka.com/ 14_NPRT_2011/Economics/3_87197.doc.htm

3. Фінансовий менеджмент Коваленко Л. О., Ремньова Л. М. Фінансовий менеджмент: Навч. посіб. - 2-ге вид., перероб. і доп. - К.: Знання, 2005. - 485 с.

УДК 65.012 .12

Радинський Сергій

кандидат економічних наук, доцент доцент кафедри економіки та фінансів

Тернопільський національний технічний університет імені Івана Пулюя м.Тернопіль, Україна

Михальська Марія-Роксолана студентка групи ПФ-51

Тернопільський національний технічний університет імені Івана Пулюя м. Тернопіль, Україна

Sergiy Radynskiy $\mathrm{PhD}$ (Economics) Docent, Assosiate Professor of Economics and Finance Department

Ternopil Ivan Puluj National Technical University Ternopil, Ukraine

Mariya-Roksolana Mykhalska Student of the group ПФ-51

Ternopil Ivan Puluj National Technical University Ternopil, Ukraine

\section{МЕХАНІЗМИ ПІДВИЩЕННЯ ЕФЕКТИВНОСТІ ЗБУТОВОЇ ДІЯЛЬНОСТІ НА ПІДПРИЕМСТВІ \\ MECHANISMS OF IMPROVING EFFICIENCY OF LANDSCAPE ACTIVITY ON ENTERPRISE}

У сучасних умовах ринкової економіки головним фактором «виживання» виробничих підприємств є ефективна збутова політика та іiі цілеспрямований розвиток. Це відбувається внаслідок значного загострення конкуренції на ринках збуту, зростання витрат діяльності, підвищення вимог споживачів відносно якісного обслуговування. У зв'язку з цим все більше значущими постають питання якості та ефективності функціонування збутової системи підприємства. Виробництво і збут продукції є першочерговими завданнями щодо реалізації місії промислового підприємства. Ці завдання можна розглядати як дві взаємопов'язані і взаємозалежні складові поняття «операційна діяльність». Слід розуміти, що показники, які характеризують цю діяльність, є відмінними. Результатом виробництва є обсяг продукції, призначеної для продажу, а результатом реалізації $\epsilon$ обсяг продукції, яка знайшла свого споживача. 
Дослідженням механізмів підвищення ефективності збутової діяльності на підприємстві розглядались в численних публікаціях, в котрих не одноразово наголошувалось про необхідність застосування різноманітності маркетингових стратегій просування продукції на ринок. Серед них необхідно відмітити праці ряду науковців, зокрема Балабанової Л. В., Маслової Т. Д., Божука С. Г., Гаркавенко С. С., Ляшенко В. І. та ін.

У ринкових умовах господарювання важливо забезпечити максимальну ефективність збутової діяльності шляхом збільшення доходу, рентабельності та зростання частки ринку вітчизняних підприємств, щоб сформувати їх конкурентоспроможність. 3 огляду на це особливої актуальності набуває дослідження сутності збутової діяльності підприємства.

На сучасному етапі розвитку економічної науки існує велика кількість підходів у визначені дефініції «збутова діяльність». Зокрема, на переконання Л. В. Балабанової визначення збутової діяльність підприємства передбачає «це все те, що забезпечує максимальну вигідність торговельної угоди для кожного з партнерів при першочерговому врахуванні інтересів і вимог проміжного або кінцевого споживача» [1, с. 15]. Дане визначення, відображає мету здійснення збутової діяльності, автори зосереджують увагу на оптимізації збутової діяльності однак не зазначають, які критерії оптимізації реалізації збутової діяльності необхідно використовувати.

Згідно $з$ визначенням С. С. Гаркавенко, «збутову діяльність - це діяльність фірми щодо планування, реалізації та контролю руху товарів від виробника до кінцевого споживача 3 метою задоволення потреб споживачів та отримання фірмою прибутку» [2, с. 365]. Однак, на нашу думку, такі характеристики відображають сутність управління збутовою діяльністю, а не політики збуту. Поряд із цим, визначення в повній мірі охоплює маркетингову складову збутової політики, проте не досить чітко відображає цілі підприємства.

У свою чергу, Т. Д. Маслова, С. Г. Божук, Л. М. Ковалік вважають, що «збутова діяльність (політика) - це поведінкова філософія або загальні принципи діяльності, яких фірма збирається дотримуватись у сфері побудови каналів розподілу свого товару та переміщення товарів у часі та просторі» [3, с. 195]. Автори зосереджують увагу на загальних принципах діяльності підприємства, однак не визначають яких саме принципів слід дотримуватися.

В. I. Ляшенко визначає збутову діяльність, як систему рішень, що приймаються продавцем 3 метою реалізації обраних стратегій і отримання найбільшого ефекту від збуту товарів [4, с. 91]. Концепція, запропонована цим автором передбачає заходи щодо просування товару, спрямоване на отримання прибутку від збуту, що потребує конкретних заходів здійснення реалізації. На наш погляд, збутова діяльність підприємства - одна із ключових ланок маркетингу, яка передбачає комплекс заходів з формування асортименту, попиту на продукцію, а також ціноутворенню та обслуговуванню покупців.

Формування збутової діяльності будь-якого підприємства передбачає визначення пріоритетних напрямків, засобів та методів, необхідних для активізації збуту. Формування збутової діяльності підприємства повинна базуватись на результатах аналізу наявної збутової системи. Причому цей аналіз доцільно здійснювати не лише за кількісними показниками, але й за якісними: рівень обслуговування, задоволеність і прихильність покупців, результативність комунікаційної політики, правильність вибору сегментів ринку, результативність роботи збутового персоналу тощо.

Досліджуючи збутову діяльність підприємства ПрАТ «Тернопільський молокозавод» необхідно відзначити зростання обсягів реалізації продукції на 29,89 \%, при цьому показник реалізації продукції становив 1,52 млрд. грн., що стало найбільшим показником збуту та найбільшим приростом за період функціонування підприємства. Аналізуючи специфіку збутової політики досліджуваного підприємства необхідно відзначити, що уся продукція об’єднана під торговою маркою «Молокія», при цьому вона має короткі терміни зберігання. Саме це і є основний аргумент щодо вибору ринків збуту [5]. Відповідно, підприємство реалізовує продукцію лише в регіонах, які розташовані поруч із Тернопільською областю - у Вінницькій, Волинській, Закарпатській, Івано-Франківській, Львівській, Рівненській, 
Хмельницькій, Чернівецькій, Житомирській областях. В даних регіонах створено власні філії ТМ «Молокія», де $є$ спеціальне холодильне обладнання, склади, відповідний транспорт та персонал, що дозволяє забезпечити процес збуту таким чином, щоб доставка продукції у кожен регіон здійснювалася щоденно. Тобто кожного дня споживачі можуть отримати свіжий продукт ТМ «Молокія», що визначає специфіку збутової діяльності даного підприємства і надає переваги поряд із іншими підприємствами-виробниками.

В умовах динамічного ринкового середовища перед підприємством ПрАТ «Тернопільський молокозавод» стоїть завдання підвищення ефективності збутової діяльності за рахунок реалізації ряду взаємопов'язаних заходів, а саме: - розширення асортименту продукції, впровадження на ринок нової і якісної продукції; - клієнтоорієнтованість, тобто наближення до кінцевого споживача та його основних вимог; - активізація маркетингових комунікацій i формування системи стимулювання збуту орієнтованої на споживача, виробничий та торгівельний персонал, а також на посередників реалізаторів продукції; розвиток транспортно-логістичної мережі для охоплення нових ринків збуту.

Перелік використаних джерел:

1. Балабанова Л. В. Стратегічне маркетингове управління збутом підприємств : підручник / Балабанова Л. В., Мітрохіна Ю. П.. - М. : Дон . ДУЕТ , 2009. - 245 с.

2. Гаркавенко С. С. Маркетинг: Підруч. для студ. екон. спец. вищ. навч. закл. / С. С. Гаркавенко - К.: Лібра, 2004. - 708 с.

3. Маслова Т. Д. Маркетинг : учебник для вузов / Т. Д. Маслова, С. Г. Божук, Л. Н. Ковалик. - СПб. : Питер, 2002. - 400 с.

4. Ляшенко В. I. Франчайзинговий режим формування регіональної мережі елементів інноваційної підприємницької інфраструктури / В. І. Ляшенко // Наукові праці ДонНТУ. Серія: економічна.- 2005. - Вип. 97. - С. 31 - 42.

5. Офіційний сайт підприємства ПрАТ «Тернопільський молокозавод» [Електронний pecypc]. - Режим доступу: https://molokija.com

УДК 338.43.01

Орел Анна

кандидат економічних наук,старший викладач кафедра організації виробництва, бізнесу та менеджменту, Харківський національний технічний університет сільського господарства імені Петра

Василенка, м. Харків, Україна

Anna Orel

candidate of economic sciences, senior teacher Department of organization of production, business and management, Kharkiv Petro Vasylenko National Technical University of Agriculture, Kharkiv, Ukraine

\section{ВПЛИВ РЕСУРСНОГО ЗАБЕЗПЕЧЕННЯ НА ДІЯЛЬНІСТЬ СІЛЬСЬКОГОСПОДАРСЬКОГО ПІДПРИЕМСТВА INFLUENCE OF RESOURCENT SUPPLY TO THE ACTIVITY OF AGRICULTURAL ENTERPRISE}

Ефективність діяльності підприємства досягається за допомогою оптимального використання наявних у його розпорядженні ресурсів, яке виражається в максимізації різниці доходів і витрат залучених ресурсів. Ресурси безпосередньо впливають на ефективність діяльності підприємств з наступних причин: 
- доходи підприємства визначаються кількістю і якістю залучених до процесу його функціонування ресурсів, її раціональною взаємодією;

- ефективно використані ресурси в майбутньому забезпечать стабільну конкурентну позицію на певному ринку;

- різниця між доходами від використання ресурсів і витратами на їх придбання та експлуатацію визначає фінансову ефективність діяльності підприємства.

У зв'язку з цим найважливіше значення набуває процес ресурсного забезпечення діяльності підприємства, який визначається як процес збору, накопичення, розподілу ресурсів, а також здійснення функцій планування, організації та контролю 3 метою ефективного та раціонального використання ресурсів та зменшення ризику в діяльності підприємства. Будь-яке підприємство представляє собою неподільну сукупність виробничих фізичних і людських ресурсів, використання яких окремо не забезпечує необхідний ефект. Таким чином, ресурсна концепція фірми ставить на визначне місце синергетичний ефект від комплексного використання ресурсів, якими володіє підприємство [1 с. 36]. При цьому даний ефект $\epsilon$ джерелом особливої продуктивності, недосяжною в умовах контрактації між виробниками і споживачами. На цьому грунтується постулат про стратегічної залежності положення підприємства в ринковому просторі від його внутрішнього стану, що характеризується, перш за все, параметрами наявних ресурсів.

Функціонування АПК базується на використанні безлічі ресурсів, різні види яких, безпосередньо беручи участь в сільськогосподарському виробництві або сприяючи його ефективної організації, формують ресурсний потенціал агропродовольчого комплексу. При цьому ресурси виступають в якості джерел формування активів сільськогосподарського підприємства, а проміжною ланкою в процесі перетворення ресурсів в активи підприємства $\epsilon$ його ресурсний потенціал. При цьому ресурсний потенціал виступає як визначальна величина ефекту від спільного використання основних видів ресурсів сільськогосподарського підприємства, а кожен окремий елемент ресурсного потенціалу володіє індивідуальною спрямованістю як фактор забезпечення розвитку підприємства, що вимагає організації механізму формування та реалізації ресурсного потенціалу, в оптимального ступеня відповідного параметрам його структури. Ресурсний потенціал являє собою не просто сукупність, а систему ресурсів, використовуваних комплексно і також передбачає обов'язкову взаємодоповнюваність окремих ресурсів. Крім того, він передбачає можливість взаємозамінності ресурсів. При цьому, доцільно проводити оцінку використання ресурсного потенціалу регіонального сільського господарства на основі використання рівного обмеженого числа оціночних параметрів для кожного 3 виділених і розглянутих елементів ресурсного потенціалу. Збалансована система показників для оцінки використання ресурсного потенціалу регіонального сільського господарства поділяється на: земельний; технічний; інноваційний; кадровий; організаційно-управлінський; інформаційний; фінансовий.

При цьому, доцільно використовувати динамічний інтегральний показник ресурсного потенціалу регіонального сільського господарства, що розраховується за формулою:

$$
R=\left(\sum_{1}^{n} \frac{P_{i 1}}{P_{i 0}}\right) / n,
$$

де Pil - значення і-го елемента ресурсного потенціалу в поточному періоді,

Pi0 - значення і-го елемента ресурсного потенціалу в попередньому періоді,

$\boldsymbol{n}$ - кількість елементів ресурсного потенціалу [3].

В даний час можна виділити два підходи до аналізу ресурсного потенціалу: статичний і динамічний. При цьому перший досліджує стан потенціалу, спираючись на результати діяльності аналізованого економічного суб'єкта, а другий - 3 позицій динаміки протікають зовнішніх і внутрішніх економічних процесів. Процес управління ресурсним потенціалом має на увазі подвійність об'єкту управління, яка полягає в тому, що, з одного боку, процес основної діяльності підприємства розглядається як найважливіший об'єкта управління і 
спрямованих на його функціонування узагальнених функцій управління, а, з іншого боку, ресурси, які беруть участь в зазначеному процесі, самі є об'єктом управління і на них також поширюється на необхідності реалізації основних управлінських функцій. Групування ресурсів $є$ найважливішим інструментом формування особливих здібностей підприємства, які створюють цінність шляхом досягнення параметрів, недоступних для конкурентів. Таким чином, використання запропонованого підходу дозволяє зробити оцінку ресурсного потенціалу сільськогосподарського підприємства з урахуванням найважливіших аспектів, що впливають на рівень ресурсного потенціалу підприємства - існуючого рівня ресурсної забезпеченості елементів потенціалу підприємства, рівня реалізації потенціалу кожного з цих елементів і впливу зовнішнього середовища на стан елементів ресурсного потенціалу. Багато недоліків, властиві існуючим методам оцінки ресурсного потенціалу сільськогосподарських підприємств, представляється можливим подолати за допомогою використання методології комплексної експертної оцінки ресурсного потенціалу, що враховує три найважливіші складові - існуючий рівень ресурсної забезпеченості всіх найважливіших елементів потенціалу підприємства, рівень реалізації потенціалу кожного 3 цих елементів і вплив зовнішнього середовища на стан елементів ресурсного потенціалу.

\section{Перелік використаних джерел:}

1. Богачов В. I. Економічна і продовольча безпека регіонів в умовах аграрної реформи: Навчальний посібник / В. І. Богачов, Д. Д. Чертков, Б. Д. Чертков. - Луганськ: Елтон-2, 2009. - 98 с.

2. Борисова, В. А. Методологічні основи аналізу фінансового стану підприємств агропромислового виробництва / В. А. Борисова // Фінанси України. - 2008. - № 10. - С. $63-$ 68.

3. Козаченко Г. В. Управління затратами підприємства: монографія / Г. В. Козаченко, Ю. С. Погорелов, Л. Ю. Хлапьонов. - Київ: Лібра, 2007. - 320 с.

4. Орликовський М. О. Оцінка інвестиційної привабливості аграрного виробництва регіону // М. О. Орликовський / Економіка АПК. - 2007. - № 1. - С. 94-98.

5. Плескач М. О. Механізми антикризового управління діяльністю сільськогосподарських підприємств в умовах трансформації / М. О. Плескач // Економіка АПК. - 2008. - № 6. - С. 84-89.

6. Попович, П. Я. Економічний аналіз діяльності суб'єктів господарювання : підруч. / Попович П. Я. - Тернопіль : Економічна думка, 2004. - 416 с. 
Орел Володимир

доктор економічних наук, доцент, кафедри організації виробництва, бізнесу та менеджменту, Харківський національний технічний університет сільського господарства імені Петра

Василенка, м. Харків, Україна Volodymyr Orel doctor of economics, associate professor, Department of organization of production, business and management, Kharkiv Petro Vasylenko National Technical University of Agriculture,

Kharkiv, Ukraine

\section{ВПРОВАДЖЕННЯ КОМПЛЕКСНОЇ СИСТЕМИ МЕНЕДЖМЕНТУ НА ПІДПРИСМСТВІ IMPLEMENTATION OF COMPLEX SYSTEM OF ENTERPRISE MANAGEMENT}

Реалізація вдосконалення продукції, спрямованої на підвищення конкурентоспроможності підприємства, вимагає впровадження в організаціях сучасних систем менеджменту якості, які відповідають міжнародним стандартам. У цих стандартах узагальнено світовий досвід системного управління якістю. Існує категорія удосконаленої продукції та іiі характеристики, які найбільшою мірою задовольняють споживача i досягаються за допомогою впровадження в діяльність підприємства системи управління якістю [2].

На сьогоднішній день успішно працює система менеджменту якості, яка дозволяє підприємству досягти наступних переваг: забезпечувати стабільність роботи організації; дозволяє уникнути випадкових «збоїв» i конфліктів, мінімізувати вплив особистісного фактора; забезпечує дотримання обов'язкових державних нормативних вимог до якості; підсилює виробничу дисципліну і покращує контроль над діяльністю підприємства; дозволяє робити роботу компанії прозорою для іï керівництва; полегшує оперативне управління i підвищує його ефективність; забезпечує зниження виробничих витрат за рахунок зниження кількості браку і підвищення ефективності праці; скорочує цикл розробки нової продукції; дозволяє досягти необхідної якості продукції i постійно підтримує його на рівні, відповідному вимогам замовників, які встановлюються в договорах і інших документах; постійно підвищує ступінь задоволеності споживача, а значить, і обсяг продажів, прибуток і конкурентоспроможність компанії; безперервно удосконалює діяльність організації в рамках напрямків і пріоритетів, що встановлюються вищим керівництвом.

Аналізуючи різні системи менеджменту, можна виявити у них загальні структурні компоненти, інтегруючи які можна досягти органічного співіснування цих систем i поліпшення не кожній окремо, а діяльності організації в цілому, що призводить до вдосконалення продукції. Правильним буде використання тієї методології або комбінації систем менеджменту, яка принесе найбільшу користь і стане «працювати» в конкретній організації. Процес розробки та впровадження комплексної системи менеджменту на підприємстві проводиться поетапно. Перший eman - планування і підготовка впровадження (він передбачає оцінку діючої системи якості, дослідження вимог споживачів та інших зацікавлених сторін. Другий eman - розробка і впровадження. (на цьому етапі здійснюється розподіл відповідальності і делегування повноважень окремим підрозділам і посадовим особам). Tpemiŭ eman - сертифікація (на заключному етапі необхідно провести самооцінку організаціі)[6].

Останнім часом багато авторів констатують той факт, що вітчизняні підприємства малоефективно використовують комплексну систему менеджменту в своїх організаціях[6]. 
Причинами низької ефективності функціонування на підприємствах э, що відсутня у керівництва і персоналу організації професійних знань і навичок в області менеджменту якості, нерозуміння того, що стандарти визначають лише мінімальні вимоги, недостатня увага питанням мотивації персоналу, орієнтованої на якість, відсутність використання інструментів менеджменту якості.

На сьогоднішній день компанії, які прийняли рішення про розробку та впровадження комплексної системи менеджменту, повинні враховувати як позитивний досвід, так і невдачі підприємств для усунення їх у своїй подальшій діяльності. Ефективна, добре структурована система менеджменту якості дозволяє організації досягти високої результативності взаємодії зі споживачами, постачальниками та іншими зацікавленими сторонами, своєчасно виявляти слабкі місця та оперативно розробляти комплекс заходів щодо вдосконалення подальшої діяльності. В сьогоденні відбувається швидкий розвиток економіки, посилення кожного дня конкуренції на світовому ринку та стрімке прискорення інтеграційних процесів, які встановлюють нові вимоги та стандарти до товарів, вироблених на підприємствах харчової галузі і їх систем управління якістю.

\section{Перелік використаних джерел:}

1. Борщевський, П. Харчова промисловість України: сучасні тенденції та перспективи розвитку //Економіка України. - 2003. - № 8. - С.45-49

2. Вітвіцький В. В. Харчова промисловість: стан та перспективи нормування праці/ В. В. Вітвіцький, А. Л. Солошонок //Економіка АПК. - 2001.- № 7. - С.22-25

3. Сичевський М. П. Стан та пріоритетні напрями розвитку харчової промисловості в Україні // Економіка АПК. - 2004.- № 1. - С. 38-42

4. Пономарьова О.С. Вплив якості продукції на конкурентоспроможність підприємства / О. С. Пономарьова//Економіка, фінанси, право.- 2009.- №5.- С. 8.

5. Траченко Л. А. Підхід до управління якістю на підприємствах харчової промисловості / Л.А. Траченко // Науковий журнал «Економіка розвитку». - Харків: Вид. ХНЕУ, 2008. - № 2. - С. 95-98.

6. Фейгенбаум А. Контроль якості продукції / А. Фейгенбаум. - К. : Діло, 2002. - 318 с. 
Панухник Олена

доктор економічних наук, професор завідувач кафедри економіки та фінансів Тернопільський національний технічний університет імені Івана Пулюя м. Тернопіль, Україна

Panukhnyk Olena

Doctor of Sciences (Economics), Professor Head of the Department of Economics and Finance Ternopil Ivan Puluj National Technical University Ternopil, Ukraine

\section{СИСТЕМНА ВЗАЕМОДІЯ СУБ'СКТІВ ЕКОНОМІЧНИХ ВІДНОСИН ЯК ОСНОВА ПОСТУПАЛЬНОГО РОЗВИТКУ ТЕРИТОРІАЛЬНО-ГОСПОДАРСЬКИХ СИСТЕМ SYSTEM INTERACTION OF ECONOMIC RELATIONS SUBJECTS AS A BASIS OF FORWARD DEVELOPMENT OF TERRITORIAL AND ECONOMIC SYSTEMS}

Осмислення політичних і соціально-економічних подій, що відбуваються останніми роками в Україні, результати економічних реформ, зокрема, впровадження процесу децентралізації, висунули потребу в пошуці ефективних моделей нарощування, інтеграції фінансово-економічного потенціалу учасників господарських відносин в контексті розгляду стійкого розвитку територій.

Дослідження проблем економічного розвитку територій повинно базуватися на теорії управління, де спеціалізація, кооперація та інтеграція різних територіальних структур $\epsilon$ важливими елементами підвищення ефективності їх функціонування. У даному контексті постановка проблеми управління територіальною економічною інтеграцією передбачає необхідність при досягненні перспектив розвитку низових соціально-економічних систем, перш за все, співставити рівні розвитку будь-якої локальної системи із загальним розвитком, наприклад, міжнародного співтовариства. У будь-якому випадку, вирішення проблем, пов'язаних із з'ясуванням тенденцій соціально-економічного розвитку, повинно грунтуватися на осмисленні передбачуваної діяльності в контексті більш глобальних систем, аніж аналізована.

По суті, співвідношення проблеми, пов'язаної з соціально-економічним розвитком будь-якої, навіть локальної економічної системи, 3 інтеграцією суспільного розвитку, передбачає створення конкретного аспекту методології стійкого розвитку. При цьому орієнтація на інтеграцію важлива не сама по собі, а як засіб у підході до вирішення проблем 3 урахуванням перспектив їх розвитку, як орієнтація на стійкий характер функціонування та розвитку системи.

Підвищений інтерес до підприємств певної території як до лідерів і каталізаторів системних перетворень в низових соціально-економічних системах, робить актуальною проблему оцінки можливостей суб'єктів економічних відносин реального сектору у прискоренні сучасних трансформаційних процесів, забезпеченні життєвих інтересів низових територіальних одиниць і регіонів та зростанні соціально-економічних стандартів.

Сучасні ринкові відносини вимагають від підприємств осмисленого оптимального використання наявного економічного потенціалу задля досягнення стійких позицій на ринку, зміцнення та розширення своїх конкурентних позицій над іншими учасниками ринку, задля забезпечення ефективності функціонування та отримання прибутку [1].

Для суб'єктів економічних відносин розрізняють наступні основні переваги системної взаємодії на регіональному рівні: 
- даний процес створює можливості розширення ринку та розвитку конкурентної боротьби, вдосконаленню способів виробництва, зменшує рівень монополії;

- розширення ринку збуту зумовлює збільшення періоду виробництва i, тим самим, зниження рівня собівартості товарів;

- інтеграція на регіональному рівні забезпечує додаткові споживчі вигоди населенню, зумовлюючи розширення асортименту продукції;

- стимулює поглиблення виробничої спеціалізації.

Основний аргумент на підтримку інтеграції на регіональному рівні - це віра в переваги, які можуть бути досягнуті в результаті використання певних інструментів та інвестиційних можливостей системної взаємодії. Але це зовсім не означає, що такі переваги будуть отримані автоматично після зближення суб' єктів господарювання до рівня інтеграції. У цілому, очікувані переваги від системної взаємодії i, особливо від повної інтеграції, можуть бути отримані в результаті скорочення витрат, пов'язаних 3 ринковими спотвореннями і бар'єрами, створеними локальною політикою; від скоординованих дій, коли ефект масштабу може бути використаний муніципальним сектором, а також скоординованої політики або створеної інфраструктури з інвестування [2].

Так, на нашу думку, основні мотиви територіальної економічної інтеграції в умовах поглиблення ринкових відносин полягають в наступному:

1. Можливість певних населених пунктів, що не володіють запасами сировинних ресурсів, отримати розвідані запаси і перспективні ліцензії без ризику і витрат, пов'язаних з геологорозвідувальними роботами. В Україні при загальному зниженні асигнувань на розвідку цей чинник стає дуже актуальним.

2. Розподіл внутрішнього ринку більшості найбільш цінних ресурсів 3 метою контролю над цінами. Можливості агресивного маркетингу, що надаються в результаті інтеграції, дозволяють підсилити економічний пресинг на конкурентів аж до витіснення їх 3 певних ринків.

3. Концентрація політичного впливу. Наявність ефективного лобі в центральній владі, яким володіють у низці регіонів, $є$ потужним чинником при отриманні вигідних державних замовлень, узгодженні умов експортних поставок i в інших сферах, що визначають добробут регіональної соціально-економічної системи та населених пунктів.

4. Комбінування взаємодоповнюючих ресурсів. Однією з проблем є невідповідність потужностей з видобування і переробки сировини. Це призводить до зниження якості планування, особливо довгострокового, вводить в нього елемент невизначеності, підвищує собівартість за рахунок різного роду витрат на укладання додаткових договорів і знижує керованість територіальними господарськими комплексами в цілому. Інтеграція у цьому випадку дозволить досягти значної економії лише за рахунок забезпечення повноцінного завантаження виробничих потужностей і підвищення ефективності об'єднаної системи планування і координації, допоможе диверсифікувати регіональні ризики, але при цьому не сприяє скороченню витрат.

5. Концентрація фінансових ресурсів для реалізації великих проектів. Наприклад, налагоджений об'єднаний фінансовий механізм дасть можливість переливу капіталу з менш рентабельних проектів в більш рентабельніші, а також скоротить обсяг оборотного капіталу в порівнянні з сумарною його величиною до злиття.

6. Економія за рахунок вертикальної інтеграції. Даний вид ефекту досягається за рахунок розширення можливостей управління і контролю.

7. Усунення неефективності. Даний мотив передбачає можливість підвищення рівня соціально-економічного розвитку унаслідок професійного менеджменту.

Таким чином, оцінка ефективності використання потенціалу підприємств реального сектору економіки $є$ важливою i необхідною для прийняття управлінських рішень, спрямованих на виявлення резервів зміцнення та нарощування фінансово-економічного потенціалу учасників господарських відносин в контексті розгляду стійкого розвитку територіально-господарських систем. 
Перелік використаних джерел:

1. Бібік Н. В. Моделі регіонального розвитку: теоретичні аспекти й особливості використання / Н. В. Бібік. - [Електронний ресурс]. - Режим доступу: http://www.nbuv.gov.ua/portal/soc_gum/Vdnuet/econ/2009_4/2.pdf.

2. Інноваційні підходи до регіонального розвитку в Україні : аналіт. доп. / [С. О. Біла, Я. А. Жаліло, О. В. Шевченко, В. І. Жук та ін. ; за ред. С. О. Білої]. - К. : НІСД, 2011. - 80 с.

УДК 65.012.1

Приймак Наталія

кандидат економічних наук, доцент, завідувач кафедри маркетингу, менеджменту та публічного адміністрування, Донецький національний університет економіки і торгівлі ім. М. Туган-Барановського м. Кривий Ріг, Україна

Natalia Priymak

$\mathrm{PhD}$ in Economic sciences, Associate Professor Donetsk National University of Economics and Trade named after Mykhaylo Tuhan-Baranovs'kyy Kryvyi Rih, Ukraine

\section{СИСТЕМА ВНУТРІШНІХ СТЕЙКХОЛДЕРІВ ЯК ОБ СКТ УПРАВЛІННЯ ЗМІНАМИ \\ SYSTEM OF INTERNAL STAYKHOLDERS AS AN ACCORDING TO THE CHANGE MANAGEMENT}

Запорука ефективного функціонування сучасного підприємства, орієнтованого на максимізацію результатів діяльності та постійне розширення сфер свого впливу - ефективне впровадження змін. Зміни є об'єктивною необхідністю, складовою системи менеджменту підприємства. Для забезпечення конкурентоспроможності та досягнення цілей підприємства зміни повинні бути керованими, тобто, на підприємстві має діяти беззупинний процес управління змінами.

Аспекти управління змінами досліджуються у наукових працях вітчизняних та закордонних науковців серед яких можна відзначити В. Боуі та Е. Хеда, П. Лоуренса, I. Адізеса, Ф. Спрінгера, I. Ансоффа, О. Ю. Гусєву, І. Б. Шевченко, К. М. Синякова, К. А. Пріб, О. О. Гайдей та інших. Дані науковці розглядають управління змінами з різних аспектів, в т.ч. виокремлюючи суб'єктів управління змінами. Проте, коло суб'єктів управління змінами науковцями трактується по-різному.

Проведене дослідження показало, що стосовно управління змінами варто виділити такий перелік суб'єктів управління змінами:

- внутрішніх стейкхолдерів підприємства;

- контактні аудиторії змін - будь-які групи людей, які проявляють реальний чи потенційний інтерес до діяльності підприємства або можуть справити на неї певний вплив через ініціювання змін;

- носіїв змін - це особливий суб’єкт управління змінами, який свідомлено чи неусвідомлено приймає участь у процесі змін та визначає успіх змін своїми діями чи бездіяльністю.

Оскільки управління змінами є внутрішньо сконцентрованим процесом, найбільш вагомим суб'єктом змін є система внутрішніх стейкхолдерів, яких ще прийнято називати внутрішньою коаліцією впливу підприємства.

Як зазначає Гаценко Л.В. «дослівно при перекладі з англійської мови стейкхолдергрупа підтримки чи група впливу. Фактично стейкхолдери - це група осіб, яка тією чи іншою 
мірою може впливати на діяльність організації» [2, с. 156]. Саме тому стейкхолдерів ще при управлінні змінам називають внутрішньою коаліцією впливу.

А. О. Аммарі зазначає, що» стейкхолдерами компанії є всі особи або групи осіб, які $\epsilon$ об'єктами або суб'єктами діяльності та політики компанії як на місцевому, так і глобальному рівнях. Стейкхолдером вважається будь-яка особа або група осіб, що впливає на діяльність організації або відчуває на собі вплив цієї діяльності, а також будь-яка особа або група осіб, які можуть допомогти в розробці пропозицій щодо підвищення комерційної та суспільної ефективності підприємства» [1, с. 151].

Для цілей управління змінами на підприємстві під стейкхолдерами будемо розуміти осіб чи їх групи, які є причетними до діяльності підприємства, мають владу чи інтерес до нього та тією чи іншою мірою можуть впливати на зміни в діяльності підприємства.

В управлінні змінами доцільно застосовувати класифікацію стейкхолдерів, запропоновану Дж. Ньюбоулд і Дж. Луффман [4, с. 78]:

1) групи впливу, що фінансують підприємство (власники, акціонери, члени суспільства тощо);

2) менеджери, які керують підприємством;

3) службовці та працівники, які безпосередньо працюють на підприємстві (зокрема, та частина, яка зацікавлена в досягненні його цілей) при реалізації змін;

4) економічні партнери, які поділяються на тих, хто фінансово допомагає розвитку (благодійники, меценати тощо), і тих , хто є споживачами результату виробництва.

Вимоги до внутрішніх стейкхолдерів (внутрішньої коаліції впливу):

- наявність влади та владних повноважень в межах підприємства чи його інтересів;

- обізнаність у змінах та інструментах їх реалізації; менеджменту.

- наявність механізму реалізації стейкхолдерів в межах певного процесу

Інструментами аналізу стейкхолдерів можуть бути:

- матриця стейкхолдерів - складається у вигляді таблиці, де експерти оцінюють як ступінь та силу впливу стейкхолдера на бізнес, так і його інтереси в аспекті діяльності суб'єкта господарювання та в аспекті провадження змін, а також визначаються можливі стратегії взаємодії;

- модель А. Мендлоу (матриця «влада/ інтерес») - передбачає класифікацію та групування стейкхолдерів за їх ставленням до влади, якою вони володіють, та міри їх інтересів (вплив на прийняття управлінських рішень сильний/слабкий; інтерес високий/низький). Це дає змогу виділити стейкхолдерів, здатних та бажаючих впливати на організацію. Відповідно, ступінь впливу стейкхолдера визначається як його владою, так й інтересом;

- матриця «влада/динамізм» ідентифікує стейкхолдерів відносно ставлення до влади, якою вони володіють, та динамізму їх положення [3].

- матриця «влада/опір» ідентифікує стейкхолдерів відповіднго до влади, якою вони наділені по відношенню до управління змінами та рівня опору змінам.

Саме такий підхід до розуміння суб'єктів управління змінами дозволяє: чітко виокремити ролі суб'єктів в ході реалізації змін; визначити відповідальність стейкхолдерів за зміни; мінімізувати опір змінам та виокремити фокуси впливу на опір який може виникнути в різних групах стейкхолдерів.

\section{Перелік використаних джерел:}

1. Аммарі А. О. Класифікація стейкхолдерів на основі взаємних очікувань / А. О. Аммарі // Актуальні проблеми економіки. - 2012. - № 8. - С. 150-155.

2. Гаценко Л. В. Теорія зацікавлених сторін (стейкхолдерів): історія розвитку та проблемні питання для подальших досліджень / Л. В. Гаценко // Водний транспорт. - 2016. Вип. 1. - С. 156-160 
3. Смачило В. В., Колмакова О. М., Коломієць Ю. В. Процедура аналізу стейкхолдерів підприємства / Економіка та суспільство, 2017, вип. № 12.-[Електронний ресурс].Режим доступу: http://economyandsociety.in.ua/ journal-12/19-stati-12/1334-smachilo-vv-kolmakova-om-kolomiets-yu-v

4. Newbould, G. and Luffman, G. (1989), Successful Business Politics, Gower, London, p. 78.

УДК 330.34

Ряснянська Альона

кандидат економічних наук, асистент кафедри підприємництва, торгівлі та біржової діяльності, Харківський національний технічний університет сільського господарства імені Петра Василенка Харків, Україна

Alyona Ryansnyanska candidate of economic sciences, Assistant of the Department of Business, Trade and Exchange Activity, Kharkiv National Technical University of Agriculture named after Peter Vasylenko, Kharkiv, Ukraine

\section{АНАЛІЗ СТАНУ МАЛОГО БІЗНЕСУ В ХАРКІВСЬКІЙ ОБЛАСТІ ANALYSIS OF THE STATE OF SMALL BUSINESS IN KHARKIV REGION}

За часів активних соціально-економічних перетворень в Україні, в умовах, коли відбувається розширення економічної самостійності регіонів та децентралізація влади, поновому визначається роль малого бізнесу для регіонального розвитку. Причиною цього є те, що малий бізнес охоплює найбільшу частку ринку та широкий спектр видів економічної діяльності, при цьому маючи значні конкурентні переваги порівняно з великим бізнесом. Але відсутність належної підтримки малого бізнесу з боку зацікавлених учасників економічних відносин породжує низку проблем щодо ефективного його функціонування та розвитку.

В Україні підприємства малого та середнього бізнесу є в усіх галузях економіки, при цьому в деяких галузях діяльність здійснюється лише суб'єктами малого підприємництва, а великих підприємств взагалі немає. Це, зокрема, стосується освіти, охорони здоров'я та надання інших видів послуг. Понад 90 \% реалізованої продукції припадає на малий бізнес у сфері фінансової та страхової діяльності, а також операцій із нерухомим майном. Загалом, у більшості галузей на малий бізнес припадає понад 50 \% реалізованої продукції [1]. Частка малих підприємств у загальній кількості суб'єктів господарювання по Україні складає близько 95 \%, середніх - близько 4 \% і великих підприємств - лише близько 1 \% (табл. 1).

Таблиця 1

Кількість підприємств в Україні у 2010-2017 рр. з розподілом за їх розмірами, од.

\begin{tabular}{|c|c|c|c|c|}
\hline \multirow{2}{*}{ Рік } & \multirow{2}{*}{ Усього } & \multicolumn{3}{|c|}{ у тому числі підприємства } \\
\cline { 3 - 5 } & & великі & середні & малі \\
\hline 2010 & 378810 & 586 & 20983 & 357241 \\
\hline 2011 & 375695 & 659 & 20753 & 354283 \\
\hline 2012 & 364935 & 698 & 20189 & 344048 \\
\hline 2013 & 393327 & 659 & 18859 & 373809 \\
\hline 2014 & 341001 & 497 & 15906 & 324598 \\
\hline 2015 & 343440 & 423 & 15203 & 327814 \\
\hline
\end{tabular}




\begin{tabular}{|l|l|l|l|l|}
\hline 2016 & 306369 & 383 & 14832 & 291154 \\
\hline 2017 & 338256 & 399 & 14937 & 322920 \\
\hline
\end{tabular}

Аналіз економічної ситуації та статистичних даних за 2010-2017 рр. показав, що відбувається тенденція до зменшення загальної кількості суб'єктів господарювання в Україні: з 378810 од. у 2010 р. до 338256 од. у 2017 р., при чому кількість малих підприємств зберігається приблизно на одному рівні протягом досліджуваного періоду 2010-2017 pp. (близько 320000 од.) [2].

Розглянемо основні показники діяльності суб'єктів господарювання по Україні у 2017 р. за розмірами підприємств: кількість зайнятих працівників у підприємствах великого бізнесу приблизно така ж як і в підприємствах малого бізнесу - 1560,9 і 1658,9 тис. осіб відповідно, у підприємствах середнього бізнесу зайнято значно більше працівників 2593,1 тис. осіб; обсяг реалізованої продукції, (товарів, послуг) у малому бізнесі 1482000,7 млн. грн, у великому бізнесі - 2929516,6 млн. грн і найбільше у середньому 1482000,7 млн. грн [2].

В регіональному розрізі найвищі показники кількості суб'єктів малого підприємництва в 2017 р. спостерігалися у Дніпропетровській (22989 од.), Одеській (20210 од.), Харківській (18297 од.), Київській (15668 од.) і Львівській (14432 од.) областях. Найнижчі показники кількості суб'єктів малого підприємництва в Луганській (2763 од.), Чернівецькій (3192 од.), Тернопільській (3720 од.), Рівненській (4177 од.) та Сумській (4481 од.) областях [3].

Харківська область поділена на 27 районів. Загальна кількість підприємств у 2017 р. становить 22597 од. В розрізі районів найбільша кількість підприємств зареєстровано в Харківському (1083 од.), Дергачівському (461 од.) та Богодухівському (218 од.); найменша кількість - в Коломацькому (38 од.), Великобурлуцькому - (57 од.) та Зачепилівському (63 од.) районах [4].

Проаналізуємо сучасний стан діяльності підприємств малого бізнесу в Харківській області в 2013-2017 рр. та визначимо основні тенденції їх розвитку (табл. 2).

Таблиця 2

Показники діяльності підприємств малого бізнесу в Харківській області в 2013-2017 pp.

\begin{tabular}{|l|c|c|c|c|c|c|}
\hline \multicolumn{1}{|c|}{ Показники } & \multicolumn{5}{c|}{ Роки } \\
\cline { 3 - 7 } & 2013 & 2014 & 2015 & 2016 & 2017 \\
\hline Кількість підприємств, од. & 24883 & 23724 & 23827 & 19328 & 21461 \\
\hline $\begin{array}{l}\text { Відсоток до загальної кількості малих } \\
\text { підприємств по Україні, \% }\end{array}$ & 6,7 & 7,3 & 7,3 & 6,6 & 6,9 \\
\hline Зайняті працівники, тис. осіб & 130,1 & 118,6 & 113,6 & 111,2 & 116,4 \\
\hline Обсяг реалізованої продукції, млн. грн & 40664,4 & 44745,9 & 65273,7 & 80385,4 & 99231,6 \\
\hline Одержали прибуток, \% & 64,3 & 64,7 & 72,3 & 70,4 & 69,6 \\
\hline
\end{tabular}

Аналіз табл. 2 показує, що кількість підприємств малого бізнесу в Харківській області за досліджуваний період зменшилася з 24883 од. у 2013 р. до 21461 од. у 2017 р., проте зросла порівняно $з$ попереднім 2016 р. (19328 од.). Однією 3 причин таких змін є кризові явища в Україні: велика кількість малих підприємств не витримують конкуренцію та банкрутують, деяким з них вдається побороти кризові явища і повернути втрачені позиції.

Аналіз кількості зайнятих працівників Харківській області свідчить про систематичне зменшення кількості працівників у підприємствах малого бізнесу з 130,1 тис. осіб у 2013 р., до 116,4 тис. осіб у 2017 р., проте порівняно з минулим роком відбулося збільшення (111,2 тис. осіб у 2016 р.).

Зменшення кількості зайнятих робітників обумовлюється скороченням кількості малих підприємств в Харківській області, а також підвищеним рівнем автоматизації праці за 
сучасних часів. Через відсутність пільгових умов при збільшенні кількості зайнятих працівників, підприємці вимушені приховувати їх, бо не мають певної зацікавленості в збільшенні їхньої кількості. Така ситуація є наслідком тіньової економіки в Україні, рівень якої в є одним з найвищих у Європі.

В цілому по області протягом 2017 р. прибутково працювало 69,6 \% підприємств, що на 1,2 \% менше, ніж у минулому році (70,4 \%) і на 5,3 \% більше, порівняно з 2013 р. (64,3 \%).

Обсяг реалізованої продукції, не зважаючи на скорочення кількості підприємств малого бізнесу в Харківській області, загалом має позитивну динаміку, що може бути пов'язане з підвищенням механізації та автоматизації виробництва, де $є$ потреба в меншій кількості зайнятих та більш якісному виробництві продукції. Підприємствами малого бізнесу Харківської області у 2017 році реалізовано продукції (товарів, послуг) на суму 99231,6 млн. грн, що на 23,4 \% більше ніж у попередньому році (80385,4 млн. грн) (рис. 3). Обсяги реалізації підприємств малого бізнесу Харківщини становили у 2017 р. 6,7 \% від загального обсягу реалізації аналогічних підприємств по Україні.

Отже, аналізуючи період 2013-2017 pp, можна зробити висновок, що в Харківській області кількість підприємств малого бізнесу зменшилась, разом з тим зменшилась кількість зайнятих робітників у малому бізнесі. Проте значно збільшився обсяг реалізованої продукції та відсоток підприємств малого бізнесу, які отримали прибуток, що свідчить про позитивні тенденції їх розвитку.

\section{Перелік використаних джерел:}

1. Якушева О. В. Економічний розвиток і підтримка малого та середнього бізнесу на регіональному рівні: десерт. на здоб. наук. ступ. канд. екон. наук / О. В. Якушева. - Черкаси, 2017. - 288 c.

2. Статистичний щорічник України за 2017 рік / За редакцією I. Є. Вернера. - Київ: Державна служба статистики України, 2017. - 541 с.

3. Статистичний збірник «Регіони України» за 2017 рік / За редакцією I. Є. Вернера. Ч. 2. - Київ: Державна служба статистики України, 2018. - 682 с.

4. Діяльність підприємств [Електронний ресурс] / Головне управління статистики в Харківській області. - Режим доступу: http://kh.ukrstat.gov.ua/index.php/stat-informatsiya. 
Тернопільський національний технічний університет імені Івана Пулюя,

м. Тернопіль, Україна

Науковий керівник: Дячун Ольга

Кандидат економічних наук, доцент, доцент кафедри економіки та фінансів, Тернопільський національний технічний університет ім. Івана Пулюя,

м. Тернопіль, Україна

Volodymyr Stasyik student group ППм-51,

Ternopil Ivan Pului National Technical University,

Ternopil, Ukraine

Scientific supervisor: Diachun Olga

D.Sc. (Econ.),

Associate Professor at the Department of Economic and Finance,

Ternopil Ivan Puluj National Technical University,

Ternopil, Ukraine

\section{ПРИБУТОК ЯК ЕКОНОМІЧНА КАТЕГОРІЯ ТА ЙОГО РОЛЬ В СУЧАСНИХ УМОВАХ \\ PROFIT AS ECONOMIC CATEGORY AND ITS ROLE IN MODERN CONDITIONS}

У сучасних умовах економічного розвитку України й формування реальної самостійності суб'єктів господарювання прибуток одержав нового змісту, оскільки в ринкових умовах прибуток виступає не тільки основним джерелом розвитку підприємства, але й $є$ стимулом його діяльності. Прибуток забезпечує інтереси держави, власників, персоналу підприємства, а тому є головною рушійною силою ринкової економіки.

Дослідження економічної природи прибутку та його ролі достатньо розкриті i представлені економічною наукою. Прибуток розглядається як дохід підприємця, як кінцевий фінансовий результат діяльності суб'єкта господарювання, як основне джерело власних фінансових ресурсів, як факторний дохід, як мета створення та функціонування суб'єктів тощо, що підкреслює його багатогранну природу.

Прибуток $є$ однією $з$ найважливіших фінансових категорій. Прибуток як об’єкт розподільчих та перерозподільчих фінансових відносин є джерелом надходження податків до бюджету держави, що будуть перерозподілені на різні напрямки, а для суб'єкта господарювання - джерелом власних фінансових ресурсів.

Роль і значення прибутку господарюючих суб'єктів в сучасних умовах виявляються в наступному:

- прибуток підприємства є основним спонукальним мотивом будь-якого виду бізнесу, головною кінцевою метою підприємницької діяльності;

- прибуток підприємства створює базу економічного розвитку держави в цілому. Можливість держави успішно виконувати покладені на неї функції і здійснювати намічені програми розвитку економіки дає механізм перерозподілу прибутку підприємства через податкову систему;

- прибуток підприємства виступає критерієм ефективності діяльності суб'єкта господарювання;

- прибуток $\epsilon$ постійно відтворюваним джерелом формування фінансових ресурсів підприємства, і чим вище рівень прибутку підприємства, тим менш його потреба у залученні 
фінансових коштів із зовнішніх джерел і вище рівень самофінансування його розвитку. Останнє є важливим критерієм фінансової стійкості підприємства;

- прибуток виступає головним джерелом зростання ринкової вартості підприємства. Прибуток як показник реального фінансового результату діяльності підприємства вже давно не використовується українськими підприємствами.

УДК 336

Химич Ірина
кандидат економічних наук
Тернопільський національний технічний університет імені Івана Пулюя
м.Тернопіль, Україна
Балацко Богдан
студент
Тернопільський національний технічний університет імені Івана Пулюя
м. Тернопіль, Україна
Iryna Khymych
PhD (Economics)
Аssosiate Professor of Economics and Finance Department
Ternopil Ivan Puluj National Technical University
Ternopil, Ukraine
Вohdan Balatsko
student
Ternopil Ivan Puluj National Technical University
Ternopil, Ukraine

\section{ФРЕЙМІНГ ЯК МЕТОД ЗАБЕЗПЕЧЕННЯ} КОНКУРЕНТОЗДАТНОСТІ БІЗНЕСУ FRAMING AS A METHOD COMPETITIVE BUSINESS SUPPORT

В світі бізнесу без комунікаційних процесів нікуди, оскільки, будь-яка діяльність так чи інакше пов'язана 3 людьми. Отримання інформаційних даних є надзвичайно важливою річчю для формування, розвитку, та й взагалі для забезпечення нормального функціонування діяльності компанії. Крім того, в сучасному бізнес-середовищі потрібно швидко та чітко «відфільтровувати» зібрану та накопичену інформацію, так як не вся вона являється цінною для діяльності компанії.

Для того, щоб ефективно використовувати та застосовувати інформаційні ресурси, доцільно скористатися методикою на основі фреймінгу (від англ. слова «framing», що означає, в дослівному перекладі, рамкування) або, іншими словами, рамкового аналізу, що виступає одним із міждисциплінарних методів наукових досліджень.

В загальному, фреймінг - це свого роду певне абстрактне поняття, яке відображає уявлення людиною якихось інформаційних даних на основі їхньої організації та структурування в ціле, із використанням свого власного життєвого досвіду, а також із врахуванням особистих наукових знань.

Основна суть фреймінгу полягає в тому, що він відображає рамкові уявлення, адже, кожна людина здатна сприймати та розуміти інформацію тільки в особистих межах власного розуміння. Тому, щоб якнайкраще спланувати власну бізнес-діяльність доцільно застосовувати дану методику і в практичній діяльності.

Так, формуючи власну справу, підприємець або керівник повинен спілкуватися 3 певною кількістю наявних та потенційних клієнтів, в кожного 3 яких присутнє особисте бачення світу бізнесу. Крім цього, і керівник має власний стиль світосприйняття бізнес- 
діяльності та бізнес-процесів, який на основі саме фреймінгу набуває специфічних рис мислення, а також за допомогою саме цієї особливості сприятиме створенню та підтримці необхідної конкурентоспроможності власної діяльності. По суті, ефективність усіх бізнеспроцесів залежить від успішності формування як тактики, так i, в кінцевому підсумку, стратегії ведення власної справи. Отже, схожі бачення щодо бізнесу як і керівника компанії, так і його клієнтів виступають одним із надзвичайно важливих аспектів планування власної діяльності.

Варто констатувати той факт, що застосування методики фреймінгу дозволить, поперше, спланувати власну бізнес-діяльність якнайкращим чином, по-друге, забезпечить довгострокову перспективу іiі існування.

В процесі формування бізнес-плану власної діяльності спочатку потрібно проаналізувати наявну ситуацію на основі бачення керівника, після чого, всі інформаційні дані співвставляються 3 баченням клієнтів. Такий підхід дозволяє чітко відтворити та підтримати імідж компанії на основі схожості бачення, а також ліквідувати можливі неспівпадіння для прийняття майбутньої стратегії діяльності компанії. Дана методика сприятиме визначенню цілісності картини бачення щодо отримання позитивного кінцевого результату компанії. Адже, найперше, на що можливо отримати відповідь, так це те, чи приведуть певні дії до бажаного результату, і чи в кінцевому результаті буде досягнуто поставленої мети, і взагалі, чи в правильну сторону спрямовано всі зусилля компанії тощо.

Отже, застосування методики фреймінгу в бізнесі посприяє ефективній оцінці та комплексності аналізу щодо контексту отримання результату: від його запланованості, $\mathrm{i}$ до його одержання.

3 вище описаного застосування методики фреймінгу в діяльності компанії варто виділити основні етапи бізнес-планування, а саме:

1) конкретизація головних цілей діяльності компанії, в тому числі й альтернативних;

2) представлення основних задач діяльності компанії;

3) створення тактичних дій щодо реалізації поставлених цілей;

4) формування головної бізнес-стратегії діяльності компанії на основі її гнучкого пристосування до швидкозмінних зовнішніх економічних умов;

5) застосування методики мінімізації ризиків у здійсненні діяльності компанії;

6) опис майбутніх очікуваних результатів;

7) коректування елементів бізнес-стратегії діяльності компанії на основі використання методики фреймінгу.

Щоб зрозуміти чи й справді новий план здатен покращити вже існуючу ситуацію в компанії, не потрібно затрачати багато часу на його вивчення, необхідно всього лиш провести порівняльний аналіз існуючої реальної та можливої майбутньої ситуації. Застосовуючи такий підхід можливо передбачити будь-яку ситуацію, і наперед сформувати певну модель поведінки компанії на ринку, що забезпечить значну й таку необхідну мінімізацію ризиків, а також сприятиме ефективності та стійкості бізнес-діяльності в умовах економічної нестабільності. 


\section{Химич Ірина \\ кандидат економічних наук доцент кафедри економіки та фінансів Тернопільський національний технічний університет імені Івана Пулюя м. Тернопіль, Україна \\ Колісник Іван студент Тернопільський національний технічний університет імені Івана Пулюя м. Тернопіль, Україна Iryna Khymych $\mathrm{PhD}$ (Economics) Assosiate Professor of Economics and Finance Department Ternopil Ivan Puluj National Technical University Ternopil, Ukraine \\ Ivan Kolisnyk student \\ Ternopil Ivan Puluj National Technical University Ternopil, Ukraine}

\section{КРЕАТИВНІСТЬ ІДЕЙ НА ОСНОВІ БРЕЙНСТОРМІНГУ CREATIVITY IDEAS BASED ON BRAINSTORMING}

Наявні методики пошуку та створення справді хороших ідей, які б стосувалися як розвитку самої компанії, так і вдосконалення продукції та послуг, інколи втрачають свій зміст, коли мова заходить про швидкість отримання якісного результату. Чому так відбувається? А все тому, що в сучасному світі одним із основних ресурсів виступають часові рамки. Швидкий плин часу вимагає чим скоріше обдумати та реалізувати в дію певну стратегію для покращення діяльності та функціонування компанії на ринку, інакше це зроблять конкуренти. Крім того, потрібно, щоб ця стратегія була ефективною та запрацювала забезпечивши компанії прибутки та інші позитивні результати (визнання, забезпечення іміджу, підтримку бренду, впізнаваність продукції чи послуг компанії тощо).

Однією з справді хороших методик, що сприятиме забезпеченню якісного результату при відборі певних ідей, являється брейнстормінг, тобто іншими словами методика пошуку необхідних та відбір найкращих стратегічних рішень на основі «мозкового штурму». Яким чином вона здійснюється? Та все просто - за короткий проміжок часу здійснюється швидка генерація великої сукупності творчих ідей, які стосуються стратегічних кроків компанії.

Основними етапами здійснення брейнстормінгу виступають такі як:

1) виявлення наявної або наявних проблеми компанії;

2) вибір та фіксування основних проблем, які потребують попереднього швидкого вирішення;

3) підбір учасників команди для вирішення визначених проблем;

4) здійснення підготовчих дій для проведення брейнстормінгу;

5) безпосереднє проведення брейнстормінгу;

6) фіксування всієї кількості згенерованих ідей учасників команди;

7) відбір найкращих ідей щодо розв’язку існуючої проблеми (проблем);

8) реалізація вибраних ідей в «життя» компанії;

9) координація реалізації ідей;

10) корегування ідей в процесі їхньої реалізації.

Головною передумовою вирішення виявленої проблеми у функціонуванні компанії являється якраз формування певної команди учасників. Адже, кожен працівник бачить 
можливий варіант вирішення даної ситуації по-своєму, а представлення певної кількості альтернатив усунення проблеми $є$ найкращим для іiі ліквідування. Крім цього, варто пам’ятати, що кількість учасників групи не повинна перевищувати десяти осіб, а умови для забезпечення генерування ідей учасників мають бути комфортними. В самій групі учасників не повинно бути емоційного тиску на вирішення існуючої проблеми, а також отримані результати не потрібно піддавати відразу ж після їхнього оприлюднення всесторонній критиці.

3 точки зору психології людське мислення поділяється на два види:

1) реактивний - даний тип мислення відображає пристосовницький характер особистості до життєвих умов;

2) проактивний - це тип мислення людей, які самостійно створюють та реалізовують найкращі умови для власного життя в усіх його аспектах.

Отже, підбираючи команду для брейнстормінгу, варто вибрати учасників не тільки за різним фаховим спрямуванням, але й за різними типами мислення, це сприятиме, в повній мірі, отриманню кращого результату для вирішення існуючих проблем. 3 одного боку, це забезпечить гнучку пристосованість до швидкозмінного зовнішнього середовища компанії, а з іншого - призведе до створення цілком нової стратегії розвитку та діяльності компанії.

Отримавши таким чином певну кількість ідей від учасників групи, потрібно грунтовно їх проаналізувати на наступні варіанти:

1) варто - не варто;

2) доцільно - недоцільно;

3) реально - нереально;

4) можливо - неможливо;

5) реалізовувати - не реалізовувати.

3 усіх вибраних варіантів, необхідно виокремити найоригінальніші, найкреативніші та найновіші ідеї, які можливо перенести в майбутню стратегію розвитку компанії. Так би мовити, необхідно забезпечити «нове дихання» компанії в конкурентному середовищі.

Метод брейнстормінгу займає досить вагоме місце в сучасному світі бізнесу, адже, в доволі стислі терміни часу сприяє пошуку новизни для вирішення існуючої проблеми чи усунення негативної ситуації. Знайшовши всього одну, але таку необхідну, відповідь на головне питання - «яким чином можна вирішити дану ситуацію?», відображає сукупність всеможливих варіантів розвитку щодо виходу з виявленої проблеми. Як відомо, в бізнесі не всі проблеми є дійсно проблемами, інколи - це один зі шляхів до активізації дії та формуванню змін на краще. 
студентка групи ПФмз-51, Тернопільський національний технічний університет імені Івана Пулюя,

м. Тернопіль, Україна

Науковий керівник: Панухник Олена

д.е.н., професор

завідувач кафедри економіки та фінансів

Тернопільський національний технічний університет ім. Івана Пулюя

м. Тернопіль, Україна

Olga Shvak

student group ПФмз-51,

Ternopil Ivan Puluj National Technical University,

Ternopil, Ukraine

Scientific supervisor: Panukhnyk Olena

D.Sc. (Econ.), Professor,

Head of the Department of Economics and Finance,

Ternopil Ivan Puluj National Technical University,

Ternopil, Ukraine

\section{СТАН ТА ДИНАМІКА РОЗВИТКУ МОЛОЧНОЇ ГАЛУЗІ УКРАЇНИ THE STATE AND DYNAMICS OF DEVELOPMENT OF THE DAIRY INDUSTRY OF UKRAINE}

Молочна промисловість - галузь харчової промисловості, що об’єднує підприємства 3 виробництва молока і різних молочних продуктів. Ця галузь є одним 3 провідних секторів української економіки, функціонування якої залежить від стану та ефективності сільського господарства. Сільське господарство та молочна галузь є важливими бюджетоутворюючими секторами економіки України.

Основними факторами, які обумовлюють географічне розміщення підприємств молокопереробної галузі, їх ефективне функціонування і розвиток $\epsilon$ наявність сировинної бази та ринку збуту готової продукції. Підприємства молочної галузі представлені у кожному регіоні, але частки їхнього виробництва істотно різняться, що дозволяє виокремити центри виробництва.

У січні 2018 року було вироблено 39282 тонн молока питного, а 28,5 \% та 12,1 \%, що в сукупності становило 40,6 \% всього виробництва та припадало відповідно на підприємства Київської та Дніпропетровської областей. В Тернопільській обл. було вироблено 6,3\% молока питного незважаючи на щільність населення в регіоні. Для порівняння в Харківській обл., де населення в 2, 5 рази більше ніж в Тернопільській обл. було вироблено 5,1\% молока питного від загального обсягу.

Сиру кисломолочного неферментованого у січні 2018 р. було вироблено 22665 тонн. Географія центрів виробництва сиру кисломолочного неферментованого є дещо відмінною, зокрема виділяємо Київську обл., частка якої становила 28,4 \% та групу підприємств, що розташовані у Дніпропетровській (10,9\%), Полтавській $(9,9 \%)$, Харківській $(9,0)$, на які припадало 28,9\% виробництва сиру кисломолочного. Частка виробництва сиру кисломолочного, що припадала на Тернопільську обл. становила 6,4 \% від загального обсягу.

Виробництво масла вершкового зосереджено у Вінницькій $(18,9 \%)$, Полтавській $(12,3 \%)$, Сумській $(8,2 \%)$ та Хмельницькій $(9,4 \%)$, у сукупності на ці регіони припадає 48,8 \% всього виробництва. У січні 2018 р. на Тернопільську область припадало 5,6\% виробленого вершкового масла. 
Лідерами виробництва сирів жирних сичужних в Україні були Харківська $(26,3 \%)$, Миколаївська (19,8\%), Київська (18,7\%), Полтавська (15,8 \%), що становить 80,5\% всього виробництва. Серед усієї номенклатури молочних виробів в Тернопільській області сирів жирних сичужних виробляється найменше, а саме 3,2 \% виробництва в Україні.

За підсумками січня 2018 року Україна поставила молочних продуктів на зовнішні ринки на суму $\$ 20,4$ млн., що на $23,7 \%$ менше, ніж у грудні минулого року, але на $87 \%$ більше, ніж у січні 2017 року. Натомість імпорт до України зріс на $80 \%$ в порівнянні з січнем 2017 року і склав \$ 6,6 млн. Торгове сальдо у січні п.р. позитивне і в сумі складає $\$ 13,7$ млн. Експорт перевищив імпорт в 3 рази.

За даними митної статистики основними експортерами продукції молочної галузі у 2018 році були: Катар (молоко та вершки); Сгипет, Молдова (сир), Нідерланди, Марокко, Туреччина (масло). Топ-експортерами в україні є: ДП «Лакталіс-Україна», ПАТ «Бель Шостка Україна», ТзОВ «КОМО» ПАТ «Золотоніський маслоробний комбінат», TOB «Пирятинський сирзавод», ПАТ «Яготинський маслозавод», ПАТ «Вінницький молочний завод «Рошен».

Перелік використаних джерел:

1. Виробництво окремих видів промислової продукції за 2011-2017 роки. [Електронний ресурc]. - Режим доступу: http://www.ukrstat.gov.ua

2. Вісник молочників 2(74) 28 лютого 2018 року. - [Електронний ресурс]. - Режим доступу: http://www.ukrmolprom.kiev.ua/ua/analitika/shchomisyachna-analitika/category/2018

УДК 336

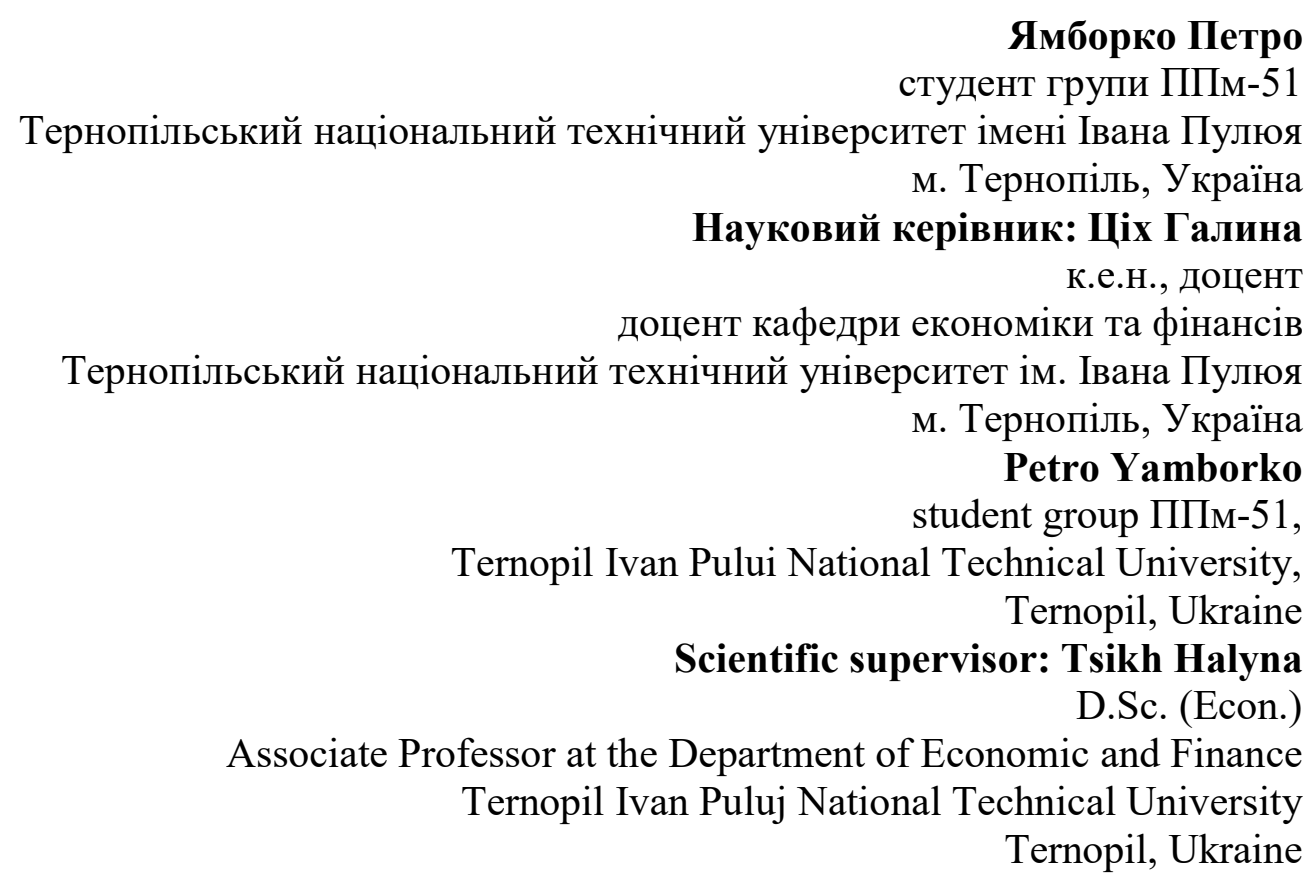

\section{ІНВЕСТИЦЙНА ПРИВАБЛИВІСТЬ ПІДПРИСМСТВА: ТЕОРЕТИЧНІ ПІДХОДИ INVESTMENT ATTRACTION OF THE ENTERPRISE: THEORETICAL APPROACHES}

Поняття «інвестиційна привабливість» сформувалося у сучасні й економічній думці відносно недавно і проходить свій власний шлях трансформації, набуває нових ознак, характеристик та тлумачень.

В Законі України «Про інвестиційну діяльність» визначено, що інвестиціями $є$ всі види майнових та інтелектуальних цінностей, що вкладаються в об'єкти підприємницької та 
інших видів діяльності, в результаті якої створюється прибуток (доход) та/або досягається соціальний та екологічний ефект [2].

У Методиці інтегральної оцінки інвестиційної привабливості підприємств та організацій [4] знаходимо наступне визначення: інвестиційна привабливість підприємства рівень задоволення фінансових, виробничих, організаційних та інших вимог чи інтересів інвестора щодо конкретного підприємства, яке може визначатися чи оцінюватися значеннями відповідних показників, у тому числі інтегральної оцінки. Таким чином під «інвестиційною привабливістю» розуміється значення кількісної оцінки та/або оцінок очікуваної задоволеності інвестора від інвестування в певне підприємство, відповідно робимо висновок, що інвестиційна привабливість характеризується сукупністю показників.

Бланк I. О. у своїй праці [1, с. 400] відстоює думку, що інвестиційна привабливість підприємства - це інтегральна характеристика окремих компаній (фірм) - об'єктів майбутнього інвестування з позиції перспективності розвитку, обсягу і перспектив збуту продукції, ефективності використання активів і їх ліквідності, стану платоспроможності та фінансової стійкості. Науковець зауважує, що досліджувана категорія $\epsilon$ інтегральною характеристикою, тобто у ній поєднані різні грані функціонування підприємства, відповідно можемо зробити висновок, що оцінити інвестиційну привабливість за допомогою одиничного показника неможливо.

Більш загальне визначення пропонує Макарій Н. [3, с. 52]: справедлива кількісна та якісна характеристика зовнішнього та внутрішнього середовища об'єкта потенційно можливого інвестування.

Інвестиційна привабливість об’єкта інвестування формується під впливом певних умов та факторів внутрішнього та зовнішнього характеру. Інвестиційна привабливість навколишнього для підприємства середовища (регіону, галузі, країни) має вплив (він може бути як опосередкований, так і суттєвий) на інвестиційну привабливість підприємства. Саме тому поняття «інвестиційна привабливість підприємства» використовується 3 поняттями «інвестиційна привабливість галузі», «інвестиційна привабливість країни», «інвестиційний клімат» тощо.

Отже, поняття «інвестиційна привабливість» $є$ достатньо дослідженим та істотних відмінностей у тлумаченнях не виявлено. Інвестиційна привабливість виступає інтегральною характеристикою діяльності підприємства, на основі якої може бути прийняте рішення щодо доцільності інвестування у нього.

\section{Перелік використаних джерел:}

1. Бланк И. А. Инвестиционный менеджмент. - К.: МП “Итем ЛТД”, “Юнайтед Лондон Трейд Лимитед”, 1995. - 448 с.

2. Закон України «Про інвестиційну діяльність» [Електронний ресурс] - Режим доступу: http://zakon5.rada.gov.ua/laws/show/1560-12

3. Макарій Н. Оцінка інвестиційної привабливості українських підприємств // Економіст. - 2001. - №10. - С. 52-60.

4. Методика інтегральної оцінки інвестиційної привабливості підприємств та організацій / Наказ Агентства з питань запобігання банкрутству підприємств та організацій від 23.02.98 № 22. [Електронний ресурс] - Режим доступу: http://zakon.rada.gov.ua/cgibin/laws/main.cgi?nreg=z0214-98 


\title{
СЕКЦІЯ 4. \\ СУЧАСНИЙ РОЗВИТОК ФІНАНСОВОГО РИНКУ УКРАЇНИ: МОЖЛИВОСТІ, ВИКЛИКИ, ЗАГРОЗИ
}

УДК 336.6

\author{
Гогусь Соломія \\ студентка групи ПО-21 \\ Тернопільський національний технічний університет імені Івана Пулюя \\ м. Тернопіль, Україна \\ Малинич Ганна \\ к.е.н. ст. викладач кафедри економіки та фінансів, \\ Тернопільський національний технічний університет імені Івана Пулюя \\ м. Тернопіль, Україна \\ Solomiia Hohus \\ student of group ПО-21 \\ Ternopil Ivan Puluj National Technical University \\ Ternopil, Ukraine \\ Hanna Malynych \\ $\mathrm{PhD}$ (Economics) \\ Ternopil Ivan Puluj National Technical University \\ Ternopil, Ukraine
}

\section{РОЛЬ ФІНАНСОВИХ РЕСУРСІВ ВІТЧИЗНЯНИХ ДОМОГОСПОДАРСТВ У ЗАБЕЗПЕЧЕННІ РОЗВИТКУ ФІНАНСОВОГО РИНКУ \\ ROLE OF FINANCIAL RESOURCES OF DOMESTIC HOUSEHOLDS IN PROVIDING FINANCIAL MARKET DEVELOPMENT}

Необхідність функціонування фінансового ринку на сучасному етапі розвитку економічних систем не викликає сумнівів, що обумовлено виконання останнім низки важливих функцій шляхом забезпечення розподільчих та перерозподільчих відносин. Одним 3 найважливіших завдань, що постають перед інститутами вітчизняного фінансового ринку $\epsilon$ сприяння формуванню фінансового мислення та поведінки домогосподарств як важливого суб'єкта фінансових відносин.

Доходи населення у 2017 році становили 2652,1 млрд. грн, витрати - 2621,4 млрд.грн, приріст заощаджень - 30,6 млрд.грн. Наявний дохід у розрахунку на одну особу становив 47269,7 грн.. Дослідження структури доходів домогосподарств у 2016-2017 роках засвідчує, що 79 \% сукупних доходів становлять заробітна плата і соціальні допомоги та інші офіційні трансферти (45,6 \% та 33,4 \%) відповідно. У структурі витрат за аналізований період встановлено, що 89 \% спрямовується на споживання товарів та послуг, а на заощадження $1,2 \%[1]$.

Незважаючи на низьку питому вагу заощаджень у структурі витрат домогосподарств вони $\epsilon$ важливим джерелом фінансових ресурсів, що можуть бути акумульовані суб' єктами фінансового ринку: депозитними корпораціями, страховими компаніями, недержавними пенсійними фондами тощо та перетворені на інвестиційні ресурси для бізнесу.

Економічна активність домогосподарств в Україні $є$ достатньо низькою, порівняно 3 економічно-розвинутими країнами. Населення не довіряє учасникам фінансового ринку і не 
володіє тими знаннями, як правильно розпоряджатися власними коштами, щоб це приносило вигоду і державі і безпосередньо їхнім власникам. Найбільший рівень довіри щодо розміщення та зберігання заощаджень вітчизняні домогосподарства виявляють до банківського сектора (рис.1).

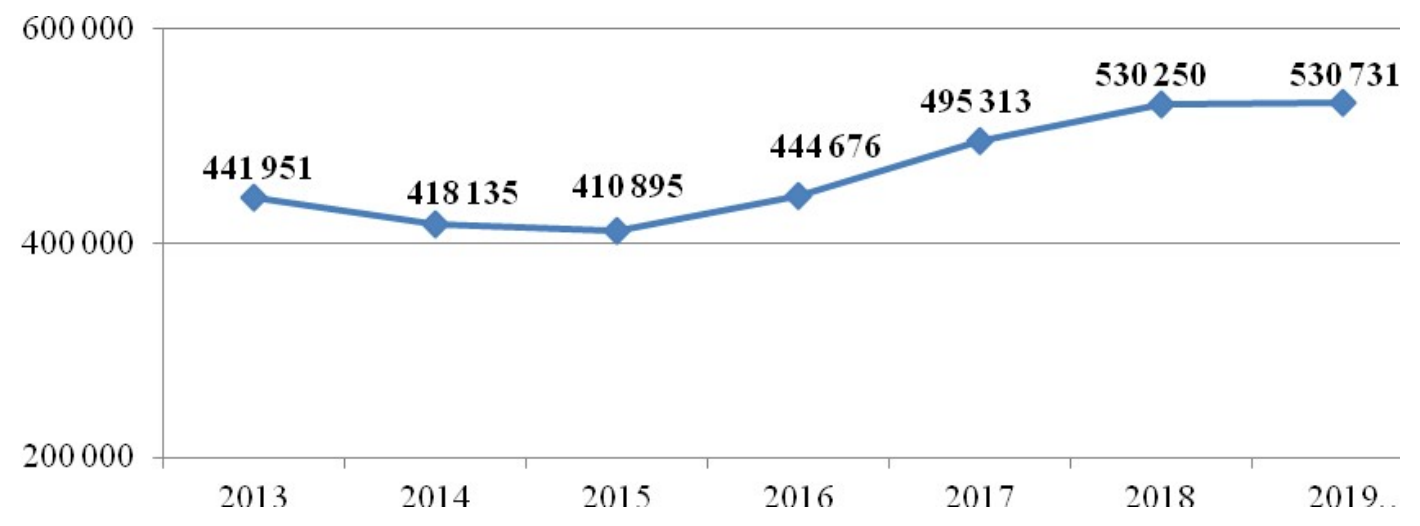

\section{Рис.1. Динаміка депозитів домашніх господарств в Україні у 2013-2019 рр, млн. грн. [2]}

Незважаючи на висхідний тренд розміру депозитів вітчизняних відзначаємо низькі темпи їхнього приросту, що обумовлено тривалим відновленням довіри після фінансової кризи та складною невизначеною політичною ситуацією в країні.

Обсяг депозитних вкладів населення змінюється синхронно зі зміною економічної та соціально-політичної ситуації в країні. У табл. 1 представлено структуру депозитів домашніх господарств у розрізі валют.

Таблиця 1

Депозити домашніх господарств у розрізі валют у 2013-2019 рр в Україні [2]

\begin{tabular}{|c|c|c|c|c|c|}
\hline Період & Гривня & $\begin{array}{c}\text { Долар } \\
\text { США }\end{array}$ & Свро & $\begin{array}{c}\text { Інші } \\
\text { валюти }\end{array}$ & Усього \\
\hline 2013 & 257829 & 150707 & 31199 & 2216 & 441951 \\
\hline 2014 & 200859 & 181146 & 34223 & 1906 & 418135 \\
\hline 2015 & 198876 & 177426 & 33034 & 1560 & 410895 \\
\hline 2016 & 209601 & 199277 & 34480 & 1318 & 444676 \\
\hline 2017 & 252439 & 203681 & 38060 & 1134 & 495313 \\
\hline 2018 & 289416 & 202567 & 37207 & 1059 & 530250 \\
\hline $\begin{array}{c}2019 \\
\text { січень }\end{array}$ & 288839 & 203395 & 37473 & 1025 & 530731 \\
\hline
\end{tabular}

Найпопулярнішою валютою депозитів домогосподарств є українська гривня, оскільки відсоткові ставки за ними є значно вищими, аніж в інших валютах, хоча існує ризик іiі девальвації відносно світових валют, а серед іноземних валют найбільшу питому вагу займають депозити у доларах США, що дозволяє отримати нижчий рівень доходу, але нівельовано ризик втрати купівельної спроможності національної валюти.

Забезпечення стабільного розвитку національної економіки позитивно позначиться на рівні доходів домогосподарств та зростанні питомої ваги заощаджень у ній. Активізація фінансових відносин між домогосподарствами та інститутами фінансового ринку забезпечить економіку країни необхідними інвестиційними ресурсами.

Перелік використаних джерел:

1. Доходи та витрати населення у 2017 році. - Режим доступу: http://www.ukrstat.gov.ua/ 
2. Грошово-кредитна та фінансова статистика. - Режим доступу: https://bank.gov.ua/control/uk/publish/article?art_id=27843415\&cat_id $=44578 \# 1$

УДК 336

Дзюрдзевич Максим

студент групи ПФм-51

Тернопільський національний технічний університет імені Івана Пулюя

м. Тернопіль, Україна

Науковий керівник: Крамар Ірина

к.е.н., доцент

Тернопільський національний технічний університет імені Івана Пулюя

Тернопіль, Україна

Maksym Dziurdzevych

student of group ПФМ -51

Ternopil Ivan Puluj National Technical University

Ternopil, Ukraine

Scientific supervisor: Iryna Kramar

$\mathrm{PhD}$, Associate Professor

Ternopil Ivan Puluj National Technical University

Ternopil, Ukraine

\section{РЕСУРСНИЙ ПОТЕНЦАЛ БАНКУ RESOURCE POTENTIAL OF THE BANK}

Банківські ресурси є основою діяльності будь-якої банківської установи, оскільки від ïх структури та умов формування залежать масштаби діяльності, обсяг ринкового сегменту, а отже, і розмір отриманого прибутку. Сутність банківських ресурсів часто розкривають через обсяг проведення пасивних операцій, суть яких полягає у залученні вкладів, отриманні кредитів від інших банків, емісії власних цінних паперів, а також проведенні операцій, внаслідок яких збільшуються ресурси банку. Саме за рахунок здійснення пасивних операцій має місце збільшення грошових ресурсів на пасивних та активно - пасивних рахунках, тобто увага акцентується на структурі формування грошових ресурсів банку - власних, залучених та позичених грошових коштів.

Часто термін «ресурсна база» ототожнюється із терміном «ресурсний потенціал». Проте, ми розглядаємо ресурсний потенціал банку, як динамічний процес, в той час як «ресурсна база» - статичний. Ресурсний потенціал пов'язаний із сукупністю усіх фінансових коштів банку, що знаходяться в безпосередньому його розпорядженні, i коштів, які потенційно можуть бути залучені банком завдяки проведенню банківської діяльності, яка сприяла б збільшенню ринкового сегменту, а також кількості та якості банківських послуг. Таким чином, ресурсний потенціал - це максимум ресурсів, які банк може залучити на фінансовому ринку. Ресурсний потенціал банку залежить від грошово-кредитної політики центрального банку, стану фінансового ринку та здатності банку купувати ресурси на первинному та вторинному ринках, а також від якості активів. При цьому фактором, що забезпечує створення та розширення ресурсного потенціалу банку є розмір його капіталу.

Одним із способів збільшення ресурсного потенціалу банку є розширення філіальної мережі та асортименту послуг банком. Проте в Україні має місце проблема розширення філіальної мережі, що пов'язано із низьким рівнем доходів населення. Вирішенням цієї проблеми може стати впровадження системи електронних фінансових інтернет-послуг.

Таким чином, важливим аспектом забезпечення ефективної діяльності банківської установи $\epsilon$ аналіз іiі ресурсного потенціалу, а ткож способів його накопичення, найоптимальніших в конкретний момент господарювання. 
Тернопільський національний технічний університет імені Івана Пулюя

м. Тернопіль, Україна

Бажанова Наталія

кандидат економічних наук

доцент кафедри економіки та фінансів

Тернопільський національний технічний університет імені Івана Пулюя

м. Тернопіль, Україна

Kateryna Dolyk

Student of the group ППс-42

Ternopil Ivan Puluj National Technical University

Ternopil, Ukraine

Bazhanova Nataliia

Ph.D. (Economics), Associate Professor

Department of Economics and Finance

Ternopil Ivan Puluj National Technical University

Ternopil, Ukraine

\section{СУЧАСНИЙ СТАН ФІНАНСОВОГО РИНКУ УКРАЇНИ ТА ШЛЯХИ ЙОГО ВДОСКОНАЛЕННЯ \\ CURRENT STATE OF THE FINANCIAL MARKET OF UKRAINE AND WAYS OF ITS IMPROVEMENT}

Актуальність теми. Досконало розвинені пенсійні фонди, страхові компанії, банківські установи та інші види фінансового ринку гарантують стабільність розвитку економічної системи в країні. Для України подальший розвиток фінансового ринку $\epsilon$ перспективою появи потужного джерела інвестицій, який буде спрямований в сектори економіки держави, шляхом нагромадження вільних грошових коштів. Діяльність фінансового ринку не може функціонувати без роботи фінансової системи, яка забезпечує його нормальне існування і розвиток.

Аналіз останніх досліджень і публікацій, в яких започатковано розв’язання даної проблеми. Вагомий внесок у дослідження питань становлення та розвитку фінансового ринку зробили відомі вчені такі як: О.А Білоус, О.Д Василик, В. М. Гриньова, Л. М. Алексеєнко, О. В Онікієнко, Г. Г Козоріз. Разом з тим зазначені проблеми в країнах 3 трансформаційною економікою вивчені поки що недостатньо,зокрема і в Україні, в якій фінансовий ринок в своєму розвитку є доволі мінливим та нестабільним.

Метою статті $\epsilon$ аналіз розвитку фінансового ринку в Україні, виявлення основних проблем та визначення перспектив його розвитку.

Виклад основного матеріалу дослідження. Саме призначення фінансового ринку полягає в забезпеченні підприємствам належних умов для залучення необхідних коштів i продажу тимчасово вільних ресурсів. У даний час активними інституційними учасниками фінансового ринку України $є$ фондові біржі, комерційні банки, страхові компанії, саме вони займають найбільшу частку фінансових ресурсів i мають прямий вплив на розвиток виробництва в країні, добробут населення і інвестиційний клімат.

Банківський сектор є найбільшою складовою фінансового ринку України з активами, що складають переважаючу частку активів усіх фінансових установ. Тому негативні тенденції у фінансовому секторі країни опинилися тут найбільш помітними. 
Усіх небанківські фінансово-кредитні установи які мають переважаючі позиції на фінансовому ринку мають страхові компанії, які кількісно і посідають не перше місце, але акумулюють понад 53,1\% усіх активів і мають значний прогрес для сприяння сталому розвитку вітчизняного підприємництва шляхом розміщення страхових резервів у реальному секторі економіки.

Фінансовий ринок повинен стати одним з основних механізмів мобілізації вільних ресурсів для розвитку економіки. Цього можна досягти за допомогою:

1) зниження рівня інфляції;

2) відновлення довіри населення до інститутів фінансового ринку;

3) стабілізації самого валютного ринку.

Висновки $з$ даного дослідження. Отже, для досягнення стабільності фінансової системи держави, перерозподілу та мобілізації фінансових ресурсів необхідно стежити за розвитком фінансового ринку самої країни. Для цього необхідно задіяти цілісну перспективну стратегію розвитку фінансового ринку, а саме:

- вирішення питання щодо реструктуризації кредитів:

- ліквідація або санації неплатоспроможних банківських установ, врегулювання питання продажу проблемних активів через формування законодавчої бази діяльності установ;

- державна підтримка щодо фінансової системи та підтримка збоку власників фінансових установ;

- поява довіри населення до банківської системи;

- запровадження механізму конвертації депозитів в акції банків.

\section{Перелік використаних джерел:}

1. Коніна М. Сучасний стан фінансового ринку України [Електронний ресурс] / М. Коніна, К. Реха, В. Янковський // ЕКОНОМІЧНИЙ ДИСКУРС Міжнародний науковий журнал Випуск 2. - 2017.

2. Офіційний сайт Державної комісії 3 регулювання ринків фінансових послуг [Електронний ресурс]- Режим доступу: https://nfp.gov.ua

3. Красавина Л. М. Міжнародні валютно-кредитні і фінансові відносини / Л. М. Красавина/-М.: Фінанси і статистика. - 2016. - С. 643. 
Тернопільський національний технічний університет імені Івана Пулюя, м. Тернопіль

Izotkin Vadym group PPm-51

Ternopil Ivan Pul'uj National Technical University, Ternopil, Ukraine

Бажанова Наталія

кандидат економічних наук, доцент кафедри економіки та фінансів

Тернопільський національний технічний університет імені Івана Пулюя, м. Тернопіль

Bazhanova Nataliia

Ph. D, Associate Professor

Department of Economics and Finance

Ternopil Ivan Pul'uj National Technical University, Ternopil, Ukraine

\section{ФІНАНСОВА ГРАМОТНІСТЬ, ЯК ГАРАНТІЯ ОСОБИСТӦ̈ ФIНАНСОВОЇ БЕЗПЕКИ \\ FINANCIAL LITERATURE AS A GUARANTEE OF PERSONAL FINANCIAL SAFETY}

Постановка проблеми. Особиста фінансова грамотність є запорукою економії та правильного розподілу сімейного бюджету.Часто маркетингові технології заставляють витрачати кошти на речі, які нам зовсім не потрібні. А це відбувається через те, що українцям бракує фінансової грамотності у буденному житті. Проте справа зайвих витрат полягає не тільки у наших проблемах з математикою, на це певним чином впливає криза, яка спонукає до економії, але у свою чергу і до активної роботи маркетологів.

Мета статті. 3'ясувати, чи варто економити, та згідно сучасних тенденцій з'ясувати сутність економії. Зрозуміти, які інструменти маркетологи застосовують, щоб змусити купувати більше, а не якісне та корисне. Довести, що особиста фінансова грамотність $\epsilon$ запорукою фінансової безпеки.

Виклад основного матеріалу. Найпоширенішими інструментами, які змушують нас купувати більше, це знижки, акції розпродажі. На рекламу і маркетинг компанії вкладають сотні мільйонів євро, а ми своїми покупками покриваємо ці витрати і приносимо додатковий прибуток виробникам і продавцям.

Поширення банківських карток у більшості випадків спростило життя кожного українця. Проте фінансова неграмотність дозволяє втрачати гроші на конвертації валют, розраховуючись банківською картою. Через нерозуміння механізму оплати в інших країнах, скасовуються платежі при розрахунку картками, Будь-яка банківська карта - це ще не рахунок, а ключ до рахунку.

Купуючи товари ми не завжди замислюємось про їх корисність. Якщо купівля товару $\epsilon$ не просто задоволення емоційного стану, а й приносить користь, то це потрібна покупка. Купуючи дорогу річ в кредит, щомісячні платежі якої дорівнюють бюджету на харчування вказує на фінансову неграмотність. Проте якщо кредит на річ, яку ти будеш використовувати для бізнесу - хороша мета для кредиту. Невиправданим $є$ те, щоб брати експрес-кредити під величезні відсотки. Такі кредити не вирішують проблеми, а посилюють їх.

Щодо депозитів, то вибирати депозитну програму в банку, потрібно орієнтуючись на розмір процентної ставки У п'яти найбільших українських банках вам запропонують на вибір більше 40 варіантів розміщення коштів. Тому люди губляться і вибирають неправильний депозит. Для вкладника найбезризиковішим буде депозит із можливістю зняти гроші в будьякий момент, умови якого передбачають, що відсотки будуть перераховуватися на той же рахунок, де розміщений депозит. 
Не завжди ми вміємо правильно розпорядитись вибором мобільного зв'язку. Невиправдано платимо декільком операторам мобільного зв'язку одночасно.

Висновок. Це лише невеликий перелік помилок, які покупець допускає при виборі того чи іншого товару або послуги. Важливо зрозуміти, що прагненням бізнесу $\epsilon$ максимальні прибутки і для цього маркетологи придумують нові прийоми та інструменти для приваблення якнайбільше покупців. Щоб уникнути зайвих витрат, потрібно ретельно зважувати усі свої витрати та намагатись підвищувати свою фінансову грамотність. Це сприятиме ефективному управлінню власним бюджетом, допоможе приймати впевнені та зважені фінансові рішення відповідно до життєвих обставин. Фінансово грамотні громадяни $€$ запорукою успішного майбутнього нашої держави.

\section{Перелік використаних джерел:}

1. Зозульов О. Формування концепції ведення бізнесу на маркетингових засадах: сьогодення та майбутнє / О. Зозульов // Маркетинг в Україні. - 2017. - № 5-6. - С. 64-72.

2. Лилик I. Першочергові завдання ГО "Українська асоціація маркетингу": пріоритети 2018 року / I. Лилик // Маркетинг в Україні. - 2017. - № 5-6. - С. 4-15.

3. Пойта I. О. Технології інтернет-маркетингу та переваги їх застосування на українському ринку / І. О. Пойта, К. Ю. Пацалюк // Вісник Київського інституту бізнесу та технологій. - 2018. - № 1. - С. 90-93.

УДК 339.187 .6

Кучеренко Світлана кандидат економічних наук доцент кафедри економіки декан фінансово-гуманітарного факультету ДВНЗ «Переяслав-Хмельницький ДПУ імені Григорія Сковороди»

м. Переяслав-Хмельницький, Україна

Малишко Віталіна

кандидат економічних наук, доцент доцент фінансів, банківської справи і страхування ДВНЗ «Переяслав-Хмельницький ДПУ імені Григорія Сковороди», м. Переяслав-Хмельницький, Україна

Svetlana Kucherenko $\mathrm{PhD}$, Associate Professor of the Department of Economics

Dean Finance and Humanities Faculty Pereiaslav-Khmelnytskyi Hryhorii Skovoroda State Pedagogical University Pereiaslav-Khmelnytskyi, Ukraine Vitalina Malyshko

$\mathrm{PhD}$ in Economics, Associate Professor Chair of Finances, Banking and Insurance Pereiaslav-Khmelnytskyi Hryhorii Skovoroda State Pedagogical University Pereiaslav-Khmelnytskyi, Ukraine

\section{ТЕНДЕНЦІЇ ТА ПЕРСПЕКТИВИ РОЗВИТКУ ЛІЗИНГУ В УКРАЇНІ TRENDS AND PROSPECTS OF LEASING DEVELOPMENT IN UKRAINE}

Лізинг відіграє роль важливого фінансового інструмента у ринковій економіці. Через лізингові операції створюються умови для розширення та оновлення основних виробничих засобів, необхідних для здійснення діяльності без значних одноразових витрат. Лізинг позитивно впливає на зниження втрат підприємств, пов'язаних з моральним старінням 
засобів виробництва. Для підприємств, які через брак обігових коштів та високий податковий тягар змушені фінансувати лише свої поточні витрати, лізинг виступає ефективною формою інвестицій.

У світовій економіці лізинг займає друге місце за обсягами інвестицій після банківського кредитування. Це один із прогресивних методів матеріально-технічного забезпечення виробництва. Лізинг уможливлює використання новітньої техніки й передових технологій, оновлення, модернізацію обладнання для підвищення власної ефективності та конкурентоспроможності. Він $\epsilon$ дієвим способом реалізації продукції підприємстввиробників активів, які можуть передаватися в лізинг. Його чисельні переваги, на відміну від традиційного банківського фінансування, спрямовані на вирішення проблем нестачі капіталу та проблем ліквідності, з якими часто стикаються й українські підприємства [1].

В Україні на вітчизняних підприємствах існує нагальна потреба в оновленні не тільки існуючої матеріальної бази, необхідність не лише в модернізації та розширенні вже діючого модельного ряду основних фондів, а й у якісному оновленні засобів виробництва. Зараз, коли терміни морального зносу техніки скорочуються, зовсім не обов'язково та й не завжди вигідно володіти яким-небудь сучасним, високотехнологічним устаткуванням, цілком достатньо одержати право на його використання. Завдяки лізинговим операціям існує реальна можливість оновлення парку машин та механізмів, підприємства мають змогу використовувати та придбавати нове устаткування та обладнання.

Завдяки лізингу в економіці в цілому можуть відбуватися позитивні зміни на шляху не лише застосування нової більш ефективної техніки, а й на шляху розвитку її виробництва. Але через низку невирішених проблем лізинг не зайняв належного місця у вітчизняній економіці. Такий стан лізингових відносин $є$ одним із гальмівних моментів розвитку виробництва в Україні, і тому саме іноземні компанії все більше його використовують. Стає очевидним, що механізм лізингу має бути спрямований на вирішення проблем розвитку лізингу в Україні саме для українських лізингодавців-інвесторів, і в першу чергу - для виробників «лізингової продукції» [2].

Станом на 1 січня 2018 року до Переліку юридичних осіб, які мають право надавати фінансові послуги та перебувають на обліку в Нацкомфінпослуг, внесено інформацію про 183 юридичних осіб - лізингодавців та 280 фінансові компанії мають діючі ліцензії, що надають послуги фінансового лізингу [3]. Протягом 2017 року фінансовими компаніями та юридичними особами, які не мають статусу фінансових установ, але можуть згідно із законодавством надавати фінансові послуги, укладено 7752 договори фінансового лізингу на суму 12967,6 млн. грн.

Вартість об'єктів лізингу, що є предметом договорів, становить 10417,5 млн. грн. Вартість чинних договорів фінансового лізингу станом на 1 січня 2018 року становить 22758,4 млн. грн. Близько 99,4 \% усіх послуг фінансового лізингу надається юридичними особами - суб'єктами господарювання, які не є фінансовими установами.

За підсумками 2017 року найбільшими споживачами лізингових послуг є:

- транспортна галузь, вартість договорів становить 7220,4 млн. грн.;

- сільське господарство, вартість договорів становить 5503,4 млн. грн.;

- сфера послуг, вартість договорів становить 1349,2 млн. грн.;

- будівництво, вартість договорів становить 1049,5 млн. грн.

За 2017 рік загальний обсяг джерел фінансування юридичних осіб - лізингодавців та фінансових компаній становить 10417,5 млн. грн., що на 2839,5 млн. грн., або на 37,5\%, більше порівняно з 2016 роком.

У структурі джерел фінансування лізингових операцій юридичних осіб лізингодавців найбільшу частку займає власний капітал 42,3 \% (4 366,5 млн. грн.).

Україні необхідні інвестиції, але не спекулятивного, а довгострокового характеру, які формують стабільну економіку. А лізингові операції - це довгострокове інвестування. Лізинг - це шлях до оновлення матеріально-технічної бази виробництва, також і шлях модернізації діючих основних фондів. Найбільш привабливими галузями для українського лізингового 
бізнесу можуть стати будівництво, авіа- та судноперевезення, сільське господарство, мале підприємництво, а також інші сфери бізнесу.

На поточний момент на ринку лізингу в Україні переважає іноземний капітал, який має стійку тенденцію до зростання. Зростання іноземного лізингового капіталу пояснюється не тим, що ринок України є привабливим, а тим, що ринок в Україні є «незаповненим», а стосовно розвинених країн - «лізинговою цілиною».

Умови ринку лізингу в Україні вибудовано так, що ведення лізингової діяльності $\epsilon$ можливим лише для великого та фінансово стійкого капіталу. Аналіз лізингового капіталу в Україні показує, що всі існуючі недоліки та перепони українських умов лізингу може долати лише великий іноземний капітал.

Для розвитку в Україні ринку лізингових послуг необхідно суттєво вдосконалити організаційно-економічне забезпечення лізингових операцій на якісно новому рівні, прискорити державне регулювання законодавства для максимальної реалізації потенційних можливостей до оновлення основних засобів та впровадження новітніх технологій.

Таким чином, ринок лізингових послуг в Україні має позитивну тенденцію зростання обсягів діяльності й стрімко розвивається. Незважаючи на економічно-фінансову кризу, позитивним фактором є те, що після різкого спаду у 2009 р. спостерігається поступове зростання обсягів лізингових операцій, кількості угод, вартості активів, наданих у лізинг, та пожвавлення на ринку лізингу в цілому. Враховуючи проведений аналіз та виявлені тенденції, за умови стабілізації економічної ситуації подальший розвиток ринку лізингових послуг в Україні цілком можливий.

\section{Перелік використаних джерел:}

1. Наталія Лісовська Розвиток ринку лізингових послуг в Україні. Товари і ринки. № 1, 2010. С. 29-36.

2. Зайцев О. В., Галахова О. В., Паращенко Х. Ю. Проблеми розвитку ринку лізингу в Україні та його поточний стан. Вісник СумДУ. Серія «Економіка». № 3. 2012. C.170-180.

3. Офіційний сайт Національної комісії, що здійснює державне регулювання у сфері ринків фінансових послуг. URL : https://www.nfp.gov.ua/ 
Михайлевська Юлія студентка Університету державної фіскальної служби України м. Ірпінь, Україна

Науковий керівник: Татьяніна Світлана старший викладач кафедри банківської справи та фінансового моніторингу Університету державної фіскальної служби України м. Ірпінь, Україна Yulia Mikhailevska student at the University of the State Fiscal Service of Ukraine Irpin, Ukraine

Scientific supervisor: Svitlana Tatyanina Senior Lecturer of the Department of Banking and Financial Monitoring of the University of the State Fiscal Service of Ukraine Irpin, Ukraine

\section{ІПОТЕЧНЕ КРЕДИТУВАННЯ В УКРАЇНІ: ПРОБЛЕМИ ТА ПЕРСПЕКТИВИ РОЗВИТКУ \\ MORTGAGE LENDING IN UKRAINE: PROBLEMS AND PROSPECTS FOR DEVELOPMENT}

Іпотечне кредитування відіграє важливу роль у соціально-економічному розвитку будь-якої країни. Іпотечні кредити сприяють активному розвитку промислового комплексу, аграрного та житлового сектору національної економіки.

Однак, незважаючи на свою актуальність, досі іпотечне кредитування в Україні не отримало належного розвитку. Частка іпотеки у ВВП становить менш ніж $1 \%$, тоді як Світовим банком для країн середнього рівня розвитку цей показник встановлено на рівні 25 \% ВВП. У цілому по Свросоюзу цей показник оцінюється на рівні більше 52 \%, у США більше $76 \%$.

Становлення іпотечного ринку в Україні є однією з найбільш важливих проблем на сучасному етапі, що потребує невідкладного розв'язання. Все це обумовлює актуальність досліджень щодо особливостей іпотечного кредитування, розвитку іпотечного ринку в Україні.

Сьогодні існує науково обгрунтована думка, що розвиток іпотечного кредитування в Україні сприятиме виведенню фінансово-банківського сектору країни на новий, якісно вищий рівень інституційного розвитку, а ринок, відповідно, отримає нові, захищені, високоліквідні та соціально виправдані довгострокові фінансові інструменти, що дасть можливість різним верствам населення отримати власне житло, залучити інвестиції в галузь житлового будівництва, забезпечити роботою велику кількість громадян. Тому в перспективі іпотечне кредитування має стати одним із найважливіших засобів забезпечення зобов'язань, пов'язаних із довгостроковими інвестиціями, але на сучасному етапі існує ряд проблем, які перешкоджають цьому [3, с. 329].

Доцільно розглянути та проаналізувати динаміку іпотечного кредитування за останні роки на українському ринку житла (табл. 1).

Таблиця 1

Іпотечні кредити фізичних осіб у кредитному портфелі банків

\begin{tabular}{|lc|c|c|c|c|c|c|}
\hline Роки & & на & на & на & на & на & на \\
& & 1.01 .2013 & 1.01 .2014 & 1.01 .2015 & 1.01 .2016 & 1.01 .2017 & 1.01 .2018 \\
\hline $\begin{array}{l}\text { Іпотечні } \\
\text { млн.грн }\end{array}$ & кредити, & 110725 & 97431 & 63158 & 56270 & 72156 & 60215 \\
\hline
\end{tabular}

Джерело: складено автром на основі статистичних даних НБУ 
За даними таблиці 1 розвиток іпотечного кредитування в Україні має негативну тенденцію до зменшення. Портфель іпотечних кредитів банків станом на 01.01.2013 становив 110,7 млн. грн., на 01.01.14 - 97,4 млн. грн., а станом на 01.01.15 - лише 63,2 млн. грн. У 2015 р. спад продовжувався: залишки кредитів фізичних осіб на нерухомість на початок 2016 р. досягли свого мінімуму в 56,2 млн. грн. на початок 2017 р. обсяг іпотечних кредитів несуттєво збільшився - до 72,2 млн. грн., що пояснюється значним зростанням офіційного курсу національної валюти і великою часткою іпотечних кредитів в іноземний валюті в структурі іпотечного портфелю. Станом на початок 2018 року знову спостерігається тенденція до зменшення обсягів іпотечного кредиту.

Як бачимо, сьогодні спостерігається неефективність іпотечної системи та іпотечного ринку, а отже необхідно визначити проблеми, що існують на даному етапі та перспективи покращення ситуації на іпотечному ринку України.

Розвиток іпотечного кредитування, насамперед, залежить від адекватного законодавства, яке має забезпечувати, 3 однієї сторони, надійний захист як іпотечного кредитора, так і позичальника, з іншої, - передбачати стимули для подальшого розвитку та вдосконалення усього комплексу правовідносин у цій сфері. Відсутність такого законодавства до останнього часу практично унеможливлювало розвиток ринку іпотечних кредитів [2, с. 105]. Іпотечне кредитування регулюється значною кількістю законодавчих актів, які $\epsilon$ досить розрізненими та суперечливими, що чинить негативний вплив на привабливість іпотечного кредитування.

Однією з основних проблем для держави є неефективність інституційної структури іпотечного ринку, що стимулює розвиток тіньового та напівлегального секторів ринку нерухомості, що в свою чергу призводить до уповільнення темпів зростання обсягів іпотечного кредитування [3, с. 328].

Крім того, однією з перешкод, з якою стикнувся іпотечний ринок України, є надто високі відсоткові ставки, що $\epsilon$ важким тягарем для бажаючих отримати кредит на нерухомість. Станом на початок 2019 року відсоткові ставки за іпотечним житловим кредитуванням в Україні становили в середньому 21,4 \% ефективної банківської ставки, що $\epsilon$ найвищими у світі.

Наразі в Україні серед інших є ще одна, не менш суттєва проблема, яка заважає запровадженню та стабільному розвитку системи іпотечного кредитування - відсутність довіри зі сторони потенційних інвесторів та кредиторів до первинних механізмів застави нерухомості - іпотеки. [2, с. 104].

Отож, можна виділити такі основні проблемами іпотечного кредитування в Україні на сучасному етапі: недосконалість правової бази; недовіра населення до українських банків та побоювання щодо втрати свого житла у разі банкрутства банка-кредитора; низька ефективність ринку житлового будівництва; неспроможність банківської системи працювати за міжнародними схемами реінвестування; відсутністю розуміння населенням процесів іпотечного фінансування; досить жорсткі умови надання іпотечних кредитів; несприятлива ситуація на фінансовому ринку в Україні.

Проте незважаючи на нестабільну ситуацію, що склалася на фінансовому ринку, іпотечний ринок у перспективі є одним із найперспективніших сегментів кредитного ринку України. Іпотечне кредитування може стати одним із найголовніших факторів покращення якості життя населення та дозволить вирішити цілий ряд соціально-економічних проблем.

Перспективи розвитку іпотечного кредитування в Україні забезпечуються колосальним попитом на нове житло: близько 1,2 млн. сімей знаходяться у черзі. Також середня забезпеченість населення житлом не перевищує $20 \mathrm{~m}^{2}$ на людину, а близько $60 \%$ житлового фонду вимагає реконструкції [1, с. 226].

На основі вище сказаного можна визначити такі пріоритетні напрями стимулювання розвитку іпотечного ринку в Україні: завершення формування нормативно-правової бази 3 питань іпотечного кредитування; створення конкуренції між банками на вітчизняному ринку, 
що підвищує привабливість самої іпотеки; активізація участі держави в іпотечному кредитуванні; формування сприятливих умов для залучення фінансових ресурсів у сферу іпотечного кредитування; зниження відсоткових ставок та збільшення термінів кредитування. Реалізація зазначеного вище у комплексі з продовженням ринкових реформ в Україні сприятимуть економічному зростанню та соціально-економічному розвитку.

\section{Перелік використаних джерел:}

1. Соковець-Макатуха Т. В. Сучасний стан іпотечного кредитування як важливого елементу фінансово-кредитного механізму забезпечення населення доступним житлом в Україні/ Т. В. Соковець-Макатуха//Ефективна економіка. - 2016. - №5 - с. 224-231

2. Філик Н. В. Роль іпотечного кредитування у становленні ринку житла в Україні: основні проблеми/ Н. В. Філик О. О. Чемериська// Юридичний вісник. - 2017. - Вип. 2 c. $102-106$.

3. Юркевич О. М. Сучасний стан ринку іпотечного житлового кредитування в Україні/ О. М. Юркевич// Економіка і суспільство. - 2016. - Вип.4. - с. 327-332.

УДК 336.71

Прийма Антоніна

студентка групи ПФм-61

Тернопільський національний технічний університет імені Івана Пулюя

м. Тернопіль, Україна

Тимошик Наталія

кандидат економічних наук, доцент

Тернопільський національний технічний університет імені Івана Пулюя

м. Тернопіль, Україна

Antonina Pryima

student of group ПФМ-61

Ternopil Ivan Puluj National Technical University

Ternopil, Ukraine

Nataliya Tymoshyk

$\mathrm{PhD}$ (Economics), Associate Professor

Ternopil Ivan Puluj National Technical University

Ternopil, Ukraine

\section{ІДЕНТИФІКАЦІЯ БАНКІВСЬКИХ РИЗИКІВ В СИСТЕМІ ФІНАНСОВОГО ПЛАНУВАННЯ \\ IDENTIFICATION OF BANK RISKS IN THE FINANCIAL PLANNING SYSTEM}

Проблема створення ефективної системи фінансового планування та ризикменеджменту у банківських установах так і залишилася однією з невирішених задач, які поставила ще криза 2008-2009 р. Тому подальший розвиток банківської системи в Україні вимагає удосконалення систем оцінювання ризиків, впровадження, з одного боку, сучасних підходів до оцінки та хеджування ризику (Базель III), а з іншого боку, методів урахування особливостей функціонування внутрішнього ринку, специфіки економічного та політичного розвитку в Україні.

Дослідженням окремих аспектів первинного фінансового моніторингу в банках та питань ідентифікації клієнтів займалися такі вітчизняні та зарубіжні вчені, як O. I. Барановський, О. Бережний, С. Дмитров, В. Коваленко, Н. Швець, В. Танци, Д. Масціандаро, Дж. Волкер та інші. Вченими зроблено значний внесок у розроблення проблематики нелегальних фінансів, боротьби 3 відмиванням доходів та формуванням 
заходів запобігання використанню банківських установ для легалізації доходів, одержаних злочинним шляхом.

Сучасний банківський ринок немислимий без ризику. Ризик присутній у будь-якій операції, тільки він може бути різних масштабів і по-різному мінімізовуватися. Не існує таких банківських операцій, які б повністю виключали ризик і заздалегідь гарантували б певний фінансовий результат. Отже, для банківської діяльності важливим є не уникнення ризику загалом, a передбачення i зниження його до мінімального рівня. Банківський ризик - це ситуативна характеристика діяльності банку, що відображає невизначеність іiі результату і характеризує імовірність негативного відхилення дійсності від очікуваного.

Актуальність проблеми полягає в тому, що банківська діяльність піддається великому числу ризиків, так як банк, крім функції бізнесу, несе в собі функцію суспільної значимості та провідника грошово-кредитної політики, тобто знання, визначення і контроль банківських ризиків становить інтерес для великого числа зовнішніх зацікавлених сторін: НБУ, акціонери, учасники фінансового ринку, клієнти. У дослідженні ризику доцільно розмежувати два ключових напрямки - розпізнавання і оцінка рівня ризику і прийняття рішень щодо ризику.

Ризик-менеджмент, а особливо банківський на сьогодні стає невід'ємним структурним елементом загальної системи менеджменту із взаємопов'язаними компонентами: ризиками;

1) системою регламентів, процедур, встановлення лімітів в процесі управління

2) сукупністю економіко-математичних моделей, що дають можливість в кількісній формі оцінювати ризики банку;

3) програмного забезпечення, що на основі економіко-математичних моделей дозволяє оптимізувати ризики.

Окрім цього, управління ризиками має включати структурний блок, що складається із двох взаємопов'язаних та рівноцінних складових: підсистеми попередження можливих ризиків та підсистеми ідентифікації ризиків.

Так, попередження та раннє реагування є можливим лише завдяки тому, що у банку при проведенні значних за обсягом операцій діє прогноз-система, тобто всебічне дослідження специфіки операції та виявлення можливого комплексу ризиків, що можуть виникати.

Що ж до другого компоненту у структурному блоці системи ризик-менеджменту ідентифікації, то виходячи із мети та об'єкту дослідження, зупинимося на більш детальному ії вивченні.

Згідно визначення поняття, “ідентифікація” походить від латинського “identificare” “ототожнювати” і означає встановлення чи визначення тотожності, ототожнення об'єкта пізнання, розпізнавання [2, 337]. Основним завданням ідентифікації є визначення масштабів, формування аналогій об'єктів та їх класифікація. Ідентифікація встановлює відповідність об'єкту своєму образу - сутнісному предмету, що нерідко носить назву ідентифікатора. У відповідності до цього ідентифікація ризиків є систематичним виявом ризикових ситуацій, що характерні для певного виду діяльності.

3 позиції сучасної економічної теорії, ідентифікацію ризиків визначають як формування переліку, класифікації і критеріїв ризиків у ринковій ситуації, тобто це виявлення змісту і складу ризику $[4,230]$.

Методологія ризик-менеджменту передбачає поетапність управлінського процесу.

Виходячи $з$ цього можна стверджувати, що наявність чіткої структурованості зовсім не означає, що процес управління вичерпано. Швидше за все, головним принципом у даному випадку є циклічність, де кожна його фаза (етап) нерозривно пов'язані як функціонально, так і організаційно. Як наслідок, вплив ідентифікації на кінцевий результат управління не слід розглядати як відокремлений компонент. 
Ключовими елементами ефективного управління $є$ : добре розвинені кредитна політика; кваліфіковане управління портфелем; ефективний контроль за кредитами; та, що найбільш важливо, добре підготовлений для роботи в цій системі персонал.

Отже, банківський ризик - це ситуативна характеристика діяльності банку, що відображає невизначеність іï результату і характеризує імовірність негативного відхилення дійсності від очікуваного.

При визначенні та вивченні банківських ризиків, необхідно пам'ятати, що банки в своїй діяльності стикаються не з одним певним ризиком, а з усією сукупністю різних видів ризику, що відрізняються між собою щодо місця та часу виникнення, своїм впливом на діяльність банку, і розглядати їх (ризики ) необхідно в сукупності. Зміна одного виду ризику викликають зміни майже всіх інших видів. Все це, природно, утрудняє вибір методу аналізу рівня конкретного ризику і прийняття рішення щодо його оптимізації веде до поглибленого аналізу безлічі інших ризикових чинників.

Завершуючи дослідження планування, ідентифікації та управління банківськими ризиками слід врахувати наступне. Перш за все необхідно визнати, що сучасна вітчизняна практика виявлення, аналізу й оцінки більшості банківських ризиків не дає чіткого уявлення про розміри грошових втрат, які зазнає банк від цих ризиків, а тому не відповідає вимогам часу і потребує негайного вдосконалення у світлі сучасних кризових явищ у банківській сфері та внаслідок посилення впливу банківських ризиків на діяльність банківських установ України.

Отже, як перспективну методику планування, аналізу й оцінки кредитного ризику в Україні пропонуємо підхід, що базується на грошовій оцінці кредитного ризику, відповідно до якого можна визначати розміри необхідних резервів для покриття очікуваних кредитних ризиків, а також величину необхідного економічного капіталу, що покриватиме зазнані банком кредитні ризики.

\section{Перелік використаних джерел:}

1. Камінський, А. Б. Ідентифікація, аналіз та управління операційними ризиками в українських банках (дослідження Агентства фінансових ініціатив) [Електронний ресурс]. Режим доступу: http://www.afi.com.ua

2. Тичина, В. Проблеми та практика управління банківськими ризиками у світлі Базеля II [Текст] / В. Тичина, О. Задніпровська // Вісник НБУ.- 2018. - №1 - С. 22.

3. Фінансовий моніторинг в банку: навчальний посібник / С. О. Дмитров, В. В. Коваленко, А. В. Сжов, О. М. Бережний ; за ред. С. О. Дмитрова, В. В. Коваленко. Суми : ВТД «Університетська книга», 2018. - 336 с.

4. Фрост, С. М. Настольна книга банківського аналітика: Гроші, ризики і професійні прийоми [Текст] / С. М. Фрост; пер. з англ.; за наук. ред. М. В. Рудя - Дніпропетровськ: Баланс Бізнес Букс, 2016. - 672c.

5. Tanzi V. Uses and abuses of estimates of the underground economy / V. Tanzi // Economic Journal. -2009. - Vol. 109, № 456. - P. 338-340. 
Тернопільський національний технічний університет ім. Івана Пулюя, м. Тернопіль,

Науковий керівник: Винник Тетяна кандидат економічних наук, доцент доцент кафедри економіки та фінансів Тернопільський національний технічний університет імені Івана Пулюя м.Тернопіль, Україна

Oksana Protskiv student of group ППмз-51

Ternopil Ivan Puluj National Technical University Ternopil, Ukraine Scientific supervisor: Tetiana Vynnyk $\mathrm{PhD}$ (Economics)

Docent, Assosiate Professor of Economics and Finance Department

Ternopil Ivan Puluj National Technical University

Ternopil, Ukraine

\section{ЕКОНОМІЧН БЕЗПЕКА ПІДПРИСМСТВА ТА ЇЇ ФІНАНСОВА СКЛАДОВА ECONOMIC SAFETY OF THE ENTERPRISE AND ITS FINANCIAL COMPONENT}

Основним принципом ефективного функціонування будь-якого підприємства в ринкових умовах (одним 3 критеріїв якої $є$ жорстка конкуренція) $є$ спрямування його діяльності на інноваційний шлях розвитку, що забезпечує належний рівень конкурентоспроможності. Головною умовою цього є належний рівень фінансового стану, критерієм якого виступає фінансова безпека підприємства.

Будь-яку систему можна характеризувати певними рівнями безпеки: «порогом чутливості», «Порогом вразливості», «порогом спокою» і «порогом розпаду» [3; 4]. «Поріг чутливості» $є$ рівнем безпеки, за якого система починає відчувати необхідність змін у ній. «Порогом вразливості» вважається такий рівень безпеки системи, за якого система починає розбалансуватися, тобто вже відчуває зміни, які можуть призвести до іiі знищення. «Поріг спокою» - це рівень безпеки, який забезпечує іï сталий розвиток. I, нарешті, «поріг розпаду» - найнижчий рівень безпеки системи, після якого система отримує деструктивні зміни.

Як і економічна безпека фінансова безпека підприємства теж має складну структуру, яка визначається складністю фінансових відносин як всередині підприємства, так і 3 об'єктами оточуючого середовища. Скористаємося підходом до визначення структури фінансової безпеки на рівні держави [5]. До функціональної системи фінансової діяльності і відповідно - фінансової безпеки підприємства - відносять:

бюджетну - взаємовідносини з бюджетом (податки і збори до бюджетів, в разі наявності - бюджетні кредити або бюджетне фінансування);

грошово-кредитну - кредити під операційну діяльність, виплата заробітної плати працівникам, розрахунки 3 постачальниками i отримання грошових коштів від покупців продукції і послуг;

- валютну - купівля і продаж валюти, кредити в іноземних валютах, в разі здійснення експортно-імпортних операцій - розрахунки 3 іноземними споживачами $\mathrm{i}$ постачальниками продукції і послуг у валюті;

банківську - взаємовідносини підприємства з банками по кредитах і депозитах, поточних рахунках, векселях тощо;

- інвестиційну - капітальні вкладення у розвиток підприємства, у тому числі за рахунок довгострокових кредитів; 
інших підприємств;

- $\quad$ фондову - випуск або продаж підприємством власних акцій і купівля акцій

- страхову - страхування майна підприємства або результатів його діяльності, безпечної праці і збереження здоров'я працівників.

Для кращого розуміння сутності фінансової безпеки підприємства слід з'ясувати іiі зв'язок з категоріями «розвиток фінансової діяльності (фінансової системи)» і «усталеність фінансової діяльності (фінансової системи)».

Отже, оскільки розвиток підприємства інколи носить стрибкоподібний характер, то відповідно до цього належним чином має розвиватися і система фінансової безпеки, виходячи при цьому на новий рівень забезпечення параметрів своєї стабільності.

\section{Перелік використаних джерел:}

1. Ареф'єва О. В., Кузенко Т. Б. Планування економічної безпеки підприємств. К.: Вид-во Європ. ун-ту, 2004. - 170 с.

2. Горячева К. С. Фінансова безпека підприємства // Срмошенко М. М., Єрохін С. А., Стороженко О. А Фінансовий менеджмент: Курс лекцій / За наук. ред д.е.н., проф. М. М. Єрмошенка. - К.: Національна академія управління, 2004. - 506 с.

3. Данільян О. Г., Дзьобань О. П., Панов М. І. Національна безпека України: структура та напрямки реалізації: Навч. посібник. - Харків: Фоліо, 2002. - 285 с.

4. Економічна криза в Україні: виміри, ризики, перспективи / Жаліло Я. А., Бабанін О. С., Белінська Я. В. та ін.; За заг. ред. Я. А. Жаліла. - К.: НІСД, 2009. - 142 с.

5. Срмошенко М. М. Фінансова безпека держави: національні інтереси, реальні загрози, стратегія забезпечення. - К.: Київ. нац. торг.- екон. ун-т. 2001. - 309 с.

УДК 330.322

Радинський Сергій

кандидат економічних наук, доцент Тернопільський національний технічний університет імені Івана Пулюя м. Тернопіль, Україна

Serhiy Radynskyi $\mathrm{PhD}$ (Economics) Docent, Assosiate Professor of Economics and Finance Department Ternopil Ivan Puluj National Technical University Ternopil, Ukraine

\section{ІНВЕСТИЦЙНИЙ КЛІМАТ В УКРАЇНІ INVESTMENT CLIMAT IN UKRAINE}

Події останніх років значно вплинули на економічну систему країни. Конфлікт на Сході України, анексія Криму, політична та економічна нестабільність призвели до зменшення іноземних інвестицій, зокрема іноземні інвестори стикаються з невизначеністю щодо того, наскільки їхні інвестиції в Україну охороняються в час збройного конфлікту й військової окупації. Сьогодні Україна не може досягти економічного розвитку за рахунок власних фінансових ресурсів i потребує залучення іноземних коштів. Тому питання залучення іноземних інвестицій і створення сприятливого інвестиційного клімату є найбільш актуальним [1, с. 260].

3'ясовуючи особливості інвестиційної діяльності в нашій країні необхідно наголосити, що Україна має значний інвестиційний потенціал, а зокрема: $є$ одним із найбільших потенційно містких ринків в Європі; володіє багатими природними ресурсами; має високий рівень науково-дослідних розробок у багатьох галузях науки і техніки та значний науково-технічний потенціал; володіє значним сільськогосподарським потенціалом 
(вигідне географічне розташування, сприятливий клімат, родючі грунти); має добре розвинену інфраструктуру. Окрім того, привабливість української економіки для іноземних інвесторів грунтується на наявності відносно дешевої кваліфікованої робочої сили. Проте, незважаючи на ряд потенційних переваг, існують також фактори, що формують несприятливий та ризиковий інвестиційний клімат країни та гальмують надходження інвестиційних ресурсів у національну економіку. До них слід віднести: недосконалу нормативну базу з питань захисту законодавчих прав та інтересів інвесторів, нестабільну політичну ситуації, нерозвинену виробничу та соціальну інфраструктури, наявність корупційних схем, девальвація національної валюти, на явність військових дій та інше [2, c. 34-35].

Сьогодні, інвестиційний процес в Україні характеризується відсутністю стабільності та значною залежністю обсягів капітальних інвестицій від зовнішніх та внутрішніх факторів. Відновлення інвестиційної активності у після кризовий період розпочалося зі суттєвим відставанням від динаміки економічного зростання. Лише у 2016 р. вдалося зупинити процес скорочення обсягів капітальних інвестицій та забезпечити їх приріст на рівні 69,94\% порівняно із 2015 р. (рис. 1).

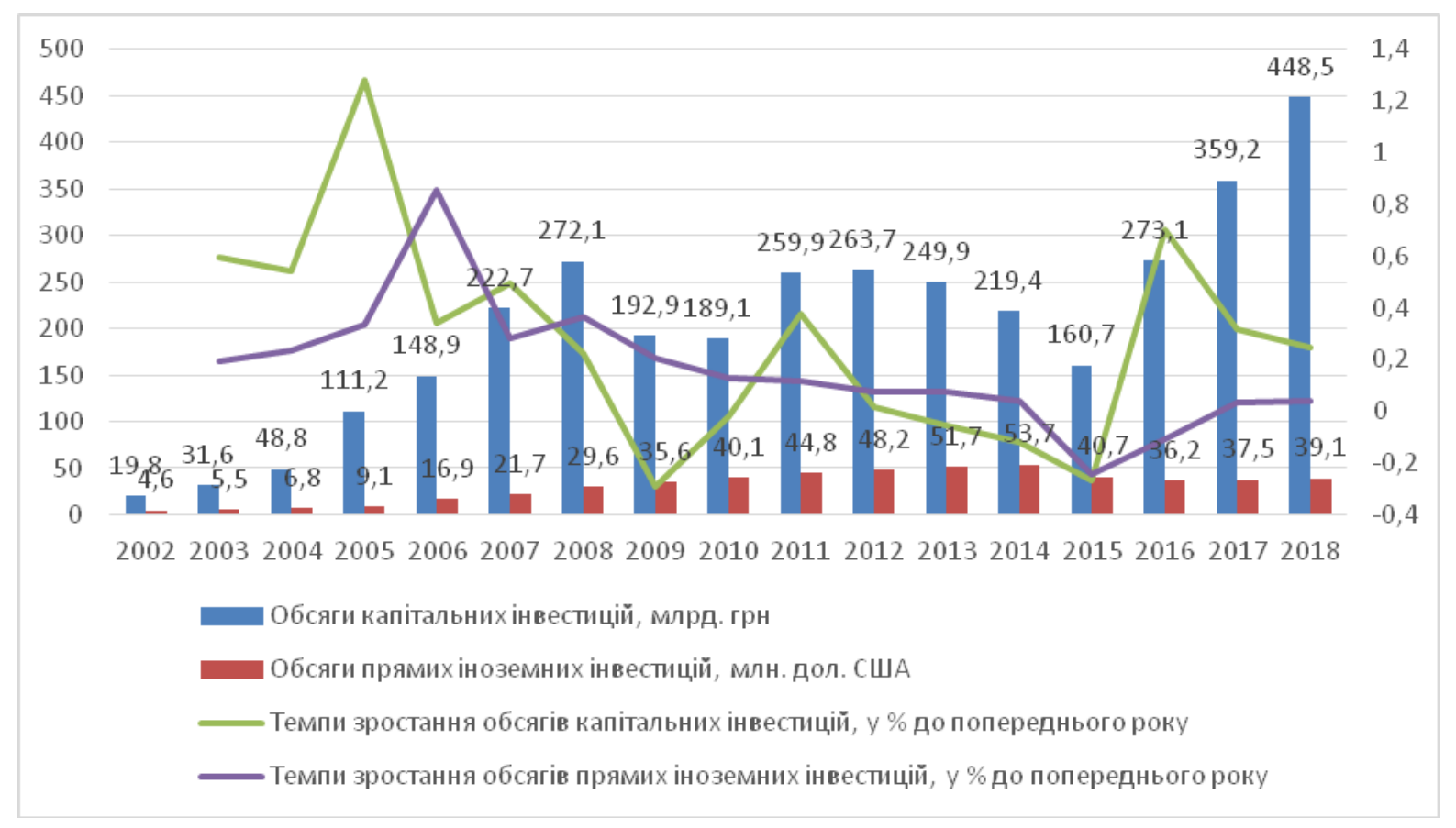

\section{Рис.1. Динаміка зміни капітальних та прямих іноземних інвестицій в Україні в 2002-2018 рр. [складено на основі [3]]}

В подальшому спостерігається динаміка до зростання обсягів, як капітальних так i прямих іноземних інвестицій в Україні. В період 2016-2017 рр. показник капітальних інвестицій зростає на $31,53 \%$, а за період 2017-2018 pp. приріст складав 24,86\%. Збільшується обсяг прямих іноземних інвестицій за період 2016-2017 рр. на 3,76 \% та за період 2017-2018 рр. на 4,35 \%.

У 2017 році спостерігається позитивна тенденція зростання обсягів прямих іноземних інвестицій як у регіональному розрізі, так і в межах усієї економіки України. Більше того, спостерігався найбільше зростання інвестиційних надходжень в центральних областях. Завдяки цьому три центральні області мали найбільші темпи нарощування обсягів капітальних інвестицій: Чернігівська область $є$ лідером за темпом приросту прямих іноземних інвестицій, відповідний показник зростання становив 78,08 \%, Кіровоградська область $-15,96 \%$, Вінницька область - $13 \%$.

Найбільший загальний темп зростання прямого іноземного інвестування мав місце у 
періоді 2012-2013 рр. і становив 7,28 \%, зростання також відбувалося за період 2016-2017 рр. на 3,76\%, а також за період 2017-2018 pp. - 4,35\%. Дане зростання відчувалося по всіх регіонах і передбачило позитивні тенденції у їх розвитку.

Подальші перспективи розвитку вітчизняної економіки базуються на широкому залученні інвестиційних ресурсів. До основних перспектив щодо залучення інвестицій в економіку України можна віднести [4, с. 166]:

- потужний природно-ресурсний потенціал, наявність кваліфікованих робочих кадрів, які можуть швидко пристосуватися до новітніх технологій стосовно виробництва, низька заробітна плата;

- $\quad$ наближеність до країн СС та територіальне розміщення загалом;

- наявність досить перспективних галузей, які потребують інвестицій, достатня кількість інноваційних бізнес ідей та проектів;

- позитивні зрушення в розвитку та вдосконаленні соціально-економічного підгрунтя для залучення інвестицій, швидка адаптованість країни до зовнішніх факторів, ризиків, світових шоків.

\section{Перелік використаних джерел:}

1.Крихівська Н. О. Інвестиційна привабливість України: основні проблеми та шляхи їх вирішення / Н. О. Крихівська, Г. М.Чернишова // Економіка та суспільство. - 2017. - №9. C. $260-264$.

2. Мордань Є. Ю. Інвестиційний клімат України та шляхи його поліпшення / Є. Ю. Мордань, А. В. Гуща // Інвестиції: практика та досвід. - 2017. - № 17. - С. 34- 38.

3. Офіційний сайт Державної служби статистики [Електронний ресурс]. - Режим доступу: http://www.ukrstat.gov.ua

4.Швець Ю. О. Оцінка інвестиційного клімату в Україні: стан, проблеми та шляхи його поліпшення / Ю.О. Швець, О.В. Бурдило // Науковий вісник Ужгородського національного університету. - 2017. - Вип.17 - ч.2. - С. 165 - 168.

УДК 336.773(477)

Степаненко Сергій

кандидат економічних наук, викладач

Харківський торговельно-економічний інститут Київського національного торговельно-економічного університету м. Харків, Україна Sergiy Stepanenko

$\mathrm{PhD}$ in Economics, Lecturer Kharkiv Institute of Trade and Economics of Kyiv National University of Trade and Economics

Kharkiv, Ukraine

\section{НАУКОВО-ТЕОРЕТИЧНІ ЗАСАДИ УПРАВЛІННЯ КРЕДИТНИМИ РИЗИКАМИ КОМЕРЦЙНОГО БАНКУ THEORETICAL AND THEORETICAL PRINCIPLES OF CREDIT RISK MANAGEMENT OF A COMMERCIAL BANK}

Одним із важливих компонентів фінансового сектору є банківська система, яка забезпечує перерозподіл тимчасово вільних коштів між суб'єктами підприємницької діяльності (резидентами та нерезидентами), населенням та державними установами. В залежності від ефективності їі функціонування реальний сектор в більший або менший мірі здатен отримувати додаткові кредитні кошти для використання ефекту фінансового 
левериджу, зростання та розвитку в цілому. Роль банківської системи в життєдіяльності домогосподарств обумовлена потребою у споживчому кредитуванні, ефективність якого відчутно впливає на рівень якості життя людей. Не менш важливу роль банківська система відіграє в обслуговуванні державного боргу країни. За останні роки банківська система України переживає не найкращі часи: 32014 року кількість платоспроможних банків скоротилася 3147 до 77 (на 12 грудня 2018 року). Якщо за весь 2018 р. кількість дієвих банків зменшилася всього на один, то 3 вересня по грудень цього ж року кількість скоротилася ще на 3. Тобто за 1 квартал ми втратили 4 банки, де 2 є результатом злиття, один змінив форму господарювання, а ВТБ-банк було визнано неплатоспроможним, який вже в стані неплатоспроможності мав загальну суму активів в обсязі 25,5 млрд грн, що за сумою поступається лише 14 з 77 діючим банкам. Це дозволяє стверджувати про досить відчутно втрату на ринку банківського продукту [1].

Визнання банку неплатоспроможним $є$ складним процесом, який базується на комплексній оцінці діяльності, але найчастіше причиною цьому виступають банківські ризики. Підходів до класифікації банківських ризиків дуже багато. В роботі [2] надано узагальнення бачення ряду авторів типів ризиків, що дозволяє стверджувати про відсутність єдності бачень. Зручну в управлінні класифікацію ризиків можна знайти в роботі [3], де вони розподілені на класи, представлені ринковими, кредитними та операційними, категорії та підкатегорії із виокремленням прямих та непрямих ризиків. Розгляд всіх ризиків $\epsilon$ трудомістким завданням, саме тому зупинимося на найбільш важливих.

Аналіз діяльності ПАТ «УкрСиббанк» за останні 4 роки, здійснений на основі звітності: 32014 по 2017 pp. [4-5] дозволяє стверджувати про відчутний вплив на результативність діяльності кредитних ризиків. Через значне зростання з 2015 по 2017 p. резервів під знецінення кредитів, цінних паперів у портфелі банку на продаж, зобов'язань, пов'язаних з кредитуванням та інше банк за цей період мав негативні фінансові результати, тенденцію до яких вдалося переломити лише у 2017 році, де в структурі активів залишилася частина непокритого збитку $(0,67 \%)$. Отже, можна зробити припущення, що однією із причин значного скорочення чисельності платоспроможних банків в Україні виступає неефективна політика управління кредитними ризиками. Під кредитним ризиком варто розуміти ризик несплати позичальником основного боргу (суми наданої позички) і відсотків, які належить сплатити банку за користування цим кредитом у визначені в договорі терміни [6]. В методичних вказівках НБУ під кредитним ризиком розуміють наявний або потенційний ризик для надходжень та капіталу, який виникає через неспроможність сторони, що взяла на себе зобов'язання, виконати умови будь-якої фінансової угоди з банком або в інший спосіб виконати взяті на себе зобов'язання [6]. Розгляд кредитного ризику як «імовірність виникнення збитків внаслідок недотримання суб'єктами кредитних відносин параметрів кредитної угоди» [6] $€$ занадто вузьким і переважно відображає результат виникнення ризику як порушення даної угоди. Фактично варто визнати кредитний ризик як вірогідність настання несприятливих подій, у формі неотримання або недоотримання банком відсотків за користування кредитом або безпосередньо суми кредиту, що може призвести до зменшення позитивного результату від фінансової діяльності або скорочення суми активів банку через збільшення суми резервів для покриття кредитних ризиків. Під управлінням кредитним ризиком варто розглядати сукупність управлінських дій, направлених на процес кредитування з метою зниження вірогідності настання несприятливих подій або зменшення їх негативного впливу на діяльність банківської установи. Зазначені дії передбачають ідентифікацію або виявлення ризику, його якісний аналіз, кількісний аналіз, моніторинг та контроль виникнення даного ризику.

Причини виникнення кредитних ризиків залежать як від банку, так і від позичальника. Банківські причини пов'язані із неефективною політикою управління даними ризиками, недосконалою оцінкою позичальника, невідповідним відображенням ситуації в кредитному договорі, відсутністю контролю за позичальником та невідповідністю кредитної політики загальному стану капіталу банку. 3 боку позичальника причини пов'язані $з$ неефективним 
управлінням підприємством, ринковим становищем, недосконалим контролем фінансового стану або навіть проявом опортуністичні поведінки, яка передбачає умисне невиконання умов кредитної угоди. Відповідно методи управління кредитними ризиками, які передбачають його оптимізацію, мають бути направлені на недопущення виникнення зазначених причин та традиційно розподіляються на зовнішні та внутрішні засоби оптимізації кредитного ризику. Серед найбільш популярних методів зовнішнього зниження варто виокремити розподіл ризику, страхування та вимоги щодо надання забезпечення. Серед внутрішніх засобів на рівні кожного окремого кредиту доцільно здійснювати оцінку кредитоспроможності разом з постійним контролем за позичальником та оперативністю в стягненні боргу в разі порушення умов угоди. На рівні кредитного портфелю оптимізаційні заходи передбачають лімітування та нормування кредитів, диверсифікацію, створення резервів та сек'юритизацію.

Таким чином, удосконалення політики управління кредитними ризиками комерційних банків, які становлять основу банківської системи нашої держави, дає можливості значно знижувати обсяги резервів для забезпечення кредитів, які впливають на рівень результативності діяльності банку, та в цілому уникнути можливих загроз його діяльності.

\section{Перелік використаних джерел:}

1. Огляд банківського сектору (02.2019 р.). Офіційний сайт Національного банку України. URL: https://bank.gov.ua/control/uk/publish/article?art_id=34661442\&cat_id=34798593

2. Управління ризиками банків : монографія у 2 томах. Т. 1: Управління ризиками базових банківських операцій / [А. О. Спіфанов, Т. А. Васильєва, С. М. Козьменко та ін.] / за ред. д-ра екон. наук, проф. А. О. Спіфанова і д-ра екон. наук, проф. Т. А. Васильєвої. - Суми : ДВНЗ “УАБС НБУ”, 2012. - 283 с.

3. Пащенко А. Д. Управління ризиками в комерційному банку. Матеріали Міжнародної науково-практичної конференції «Управління розвитком соціальноекономічних систем». - Харків: ХНТУСГ, 2018. - 322 с. - С. 142-144.

4. Публічне Акціонерне Товариство «УкрСиббанк» (код 09807750) Фінансова звітність за Міжнародними стандартами фінансової звітності та звіт незалежних аудиторів 31 грудня 2015 року. URL: https:/my.ukrsibbank.com/common/upload/ukrsibbank/financialreports/2015/finrep_annual_MSFZ_audit_2015.pdf

5. Публічне Акціонерне Товариство «УкрСиббанк» (код 09807750) Фінансова звітність за Міжнародними стандартами фінансової звітності та звіт незалежних аудиторів 31 грудня 2017 року. URL: https://my.ukrsibbank.com/common/upload/ukrsibbank/financialreports/2017/annual_report_2017_noncons_UKRSIBBANK.pdf

6. Малахова О. Л. Напрями оптимізації роботи банків щодо управління кредитним ризиком. Світ фінансів. 2017. № 2 (15). С. 101-112. 
Тимошик Наталія

кандидат економічних наук, доцент доцент кафедри економіки та фінансів Тернопільський національний технічний університет імені Івана Пулюя

м. Тернопіль, Україна

Tymoshyk Nataliia $\mathrm{PhD}$ (Economics) Docent, Assosiate Professor of Economics and Finance Department Ternopil Ivan Puluj National Technical University Ternopil, Ukraine

\section{ЕЛЕМЕНТИ ФІНАНСОВОГО МЕХАНІЗМУ ЯК ЗАСІБ УПРАВЛІННЯ ELEMENTS OF FINANCIAL MECHANISM AS A MANUAL OF MANAGEMENT}

В умовах нестабільності економічної системи України можливість вирішення питань 3 управління фінансами є суттєвим важелем забезпечення її стабілізації, сталого економічного розвитку як окремих суб'єктів господарювання, так і країни в цілому. Держава здійснює свою ціленаправлену фінансову політику через відповідний фінансовий механізм. Склад та структура цього механізму характеризуються рівнем розвитку економіки, національними та історичними особливостями кожної окремої держави, відносинами власності. Тому фінансовий механізм має стати ефективним інструментом регулювання економічних процесів всього суспільства i водночас забезпечити реалізацію намічених системних економічних реформ в державі в умовах євроінтеграції.

Питаннями ефективного фінансового управління за допомогою фінансових механізмів суб’єктів підприємництва займалися такі вчені як М. Білик, І. Бланк, О. Василик, А. Горбатенко, М. Дмитришин, I. Зятковський, М. Крупка, I. Лук’яненко, В. Опарін, К. Павлюк, А. Поддєрьогін, П. Стецюк, Дж.С. Мілль, О. Кауфман, Г. Дональдсон, І. Фішер, Дж. Хірт, Ю. Брігхем, та ін. Думка кожного з авторів заслуговує уваги, проте в умовах постійних змін ринкової кон'юнктури необхідні додаткові дослідження.

Об'єктом управління на підприємстві виступає сукупність всіх фінансових ресурсів, які знаходяться у його розпорядженні. Сюди відносяться власні (внутрішні) та позикові (зовнішні) джерела формування ресурсів [1]. До суб'єктів управління відносять персонал структурних фінансових підрозділів, які певним чином впливають на об'єкт управління. В їх функції входить збір, аналіз, обробка, систематизація, зберігання інформації, іiі передача i ухвалення управлінських рішень. Такі рішення приймаються шляхом планування, яке включає організацію діяльності, регулювання, координування та контроль [2]. Персонал повинен мати не тільки високий рівень кваліфікації, але й навики до швидкого пристосування до змін навколишнього середовища.

Процес управління фінансовими ресурсами є досить складним і тому його доцільно поділити на декілька послідовних кроків:

- формулювання проблеми;

- збір та первинна обробка даних щодо визначеної проблеми;

- аналізування одержаної інформації;

- ухвалення управлінських рішень на основі результатів аналізу;

- реалізація рішень;

- оцінювання результатів від реалізації прийнятих рішень;

- коригування результатів.

Така визначена послідовність кроків та дій спричинить до отримання більш високого результату. Крім того, залежно від поставленої проблеми при потребі будь-яку дію можна 
конкретизувати. Здебільшого успіх вирішення поставлених завдань залежить від вдало підібраних методів та прийомів підготовки самих управлінських рішень.

Оптимальне управління грошовими ресурсами здійснюється за допомогою фінансового механізму, структура якого містить п'ять взаємозалежних елементів [3]:

- фінансові методи - їх можна визначити як засіб впливу фінансових відносин на суб'єкт господарювання, який спрямовує рух грошових ресурсів. До таких методів відносять прогнозування, планування, оподаткування, кредитування, страхування та ін.;

- фінансові важелі, які виступають засобом дії фінансового методу і включають доходи, прибуток, внески до статутного капіталу, амортизаційні відрахування, фонди цільового призначення, фінансові санкції, портфельні інвестиції, відсоткові ставки за позиками, облігаціями, депозитами, фінансові норми і нормативи, фінансові стимули, орендну плату, пайові внески;

- нормативно-правове забезпечення - це вид діяльності, який регулює функціонування самого фінансового механізму i включає: Конституцію України, законодавчі акти, Укази Президента, постанови КМУ, положення міністерств з економічних та фінансових питань, міжнародні договори, накази, інструкції та інші правові документи.;

- інформаційне забезпечення функціонування фінансового механізму включає достовірну, вичерпну, зрозумілу, чітку, своєчасну інформацію, яка необхідна для прийняття фінансових рішень. Першоджерелом інформації може виступати фінансова звітність суб'єктів господарювання. Крім того, сюди входять інші показники, які характеризують мікро- та макроекономічний розвиток окремих галузей і країни загалом та визначають фінансову кон'юнктуру ринку.

Слід зауважити, що при різкому зростанні обсягів як внутрішньої, так і зовнішньої інформації, скороченні термінів іiі обробки і безпосереднього доступу доцільно було б інформаційне забезпечення розглядати з позицій і можливостей самого підприємства, тобто його сукупного інформаційно-технічного забезпечення.

До елементів фінансового механізму суб'єкта господарювання доцільно долучити адміністративно-управлінське забезпечення, яке в своїй структурі мало б фінансові органи та відповідні інституції зі своїми функціями та повноваженнями, оптимальним керівним складом здійснювало кваліфіковані керівні дії.

Таким чином, стабільність економічного зростання, покращення суспільного добробуту вимагають постійного регулювання, контролювання та вдосконалення фінансового механізму. Стан та рівень досконалості фінансового механізму в значній мірі залежать від довершеності господарського механізму загалом та його окремих елементів, зокрема, механізму адміністративно-управлінського забезпечення і підвищення результативності фінансового контролю.

\section{Перелік використаних джерел:}

1. Дмитришин М. В. Формування системи ефективного управління фінансовими ресурсами підприємства / М. В. Дмитришин, М. М. Данилишин // Актуальні проблеми розвитку економіки регіону. - 2015. - Вип. 11(2). - С. 131- 138.

2. Петрушевська В. В. Трансформаційні напрямки фінансової політики в процесі стабілізації економіки України / В. В. Петрушевська// Бізнес Інформ. - 2013. - № 11. - С. 4651.

3. Проскура В.Ф. Щодо принципів та механізму антикризового управління підприємством / В. Ф. Проскура, Е. В. Шкирта // Науковий вісник НЛТУ України. - 2012. Вип. 22.3. - С. 330-334. 


\title{
СЕКЦІЯ 5. \\ ІННОВАЦІЇ У ГЛОБАЛЬНІЙ БІРЖОВІЙ СФЕРІ ТА БАНКІВСЬКІЙ ДІЯЛЬНОСТІ
}

УДК 338.24

\begin{abstract}
Голич Наталія
аспірант кафедри економіки та фінансів

Тернопільський національний технічний університет імені Івана Пулюя м. Тернопіль, Україна

Панухник Олена доктор економічних наук, професор, завідувач кафедри економіки та фінансів Тернопільський національний технічний університет імені Івана Пулюя м. Тернопіль, Україна Nataliia Holych Postgraduate student of the Department of Economics and Finance Ternopil Ivan Puluj National Technical University Ternopil, Ukraine Olena Panukhnyk

Doctor of Sciences (Economics), Professor, Head of the Department of Economics and Finance Ternopil Ivan Puluj National Technical University Ternopil, Ukraine
\end{abstract}

\section{ДЕРЖАВНА ПІДТРИМКА ТРАНСФЕРУ ІННОВАЦІЙНИХ ПРОЦЕСІВ В МАЛОМУ БІЗНЕСІ \\ STATE SUPPORT FOR THE TRANSFER OF INNOVATION PROCESSES IN SMALL BUSINESS}

В умовах сучасності розвиток економічної системи обумовлений, насамперед, інноваційною діяльністю, яка пов'язана зі створенням і впровадженням у виробництво досягнень науково-технічного прогресу. Тому, у зв'язку із цим, стимулювання інноваційних процесів господарюючих суб'єктів стає необхідною умовою реалізації національних інтересів у системі економічної безпеки підприємства, регіону чи держави.

Проблема підтримки малого та середнього бізнесу у стимулюванні розвитку державних інноваційних процесів постає особливо актуальним питанням для української економіки, де головні фінансові ресурси інновацій генеруються у більшості випадків для великих корпоративних структур. Така ситуація вважається нормальною через панування думки, що саме великі підприємства $є$ ефективнішими від малих для технологічного розвитку держави, оскільки завдяки наявності необхідних ресурсів вони спроможні забезпечити весь інноваційний цикл реалізації новітніх науково-технічних розробок.

На нашу думку, суб’єкти малого бізнесу - це невід'ємна частина інноваційного процесу. Успіх малого бізнесу в конкурентній боротьбі залежить від їх інноваційності, гнучкості та мобільності.

У більшості країн світу понад 60 \% ВВП створюють малі підприємства, що є локомотивом розвитку економіки цих країн. Проте, аналіз української інноваційної активності показує, що найнижчий їі рівень спостерігається саме у сфері малого бізнесу - до 10 \%, тоді як у Франції - 33 \%, Великій Британії - 35 \%, Швеції - 46 \%, Фінляндії - 49 \%, Німеччині - $66 \%$ [1]. 
Світова практика інноваційної діяльності малого та середнього бізнесу свідчить, що найбільш ефективними інноваційними структурами є технопарки, технополіси, інноваційні бізнес-інкубатори, наукові та науково-технологічні центри.

Діяльність вищенаведених структур спрямована саме на створення сприятливих умов для ефективної діяльності інноваційних підприємств, що спеціалізуються на розробленні та реалізації інноваційних бізнес-ідей. Головне призначення таких структур - це створення сприятливих умов для діяльності інноваційних підприємств шляхом тимчасового забезпечення виробничими площами, матеріально-технічними засобами, дослідницьким приладдям, консалтинговими послугами.

Різні регіони України вже намагаються стимулювати створення кластерної економіки. Проте, варто зазначити, що недоліком існуючої організаційно-господарської інфраструктури інноваційної підприємницької діяльності в Україні є нерівномірність розподілу ії існуючих об'єктів за регіонами України. Так, з 255 існуючих інноваційних фондів, 175 працюють лише у Києві, що певним чином унеможливлює розвиток інноваційних проектів в інших регіонах України. Також, наприклад, у Київській області діють 12 бізнес-інкубаторів, в Одеській області - 9, а 18 з 27 регіонів країни мають лише по 1-2 бізнес-інкубатора. Нещодавно (2 березня, 2018 року) також розпочав свою діяльність регіональний бізнес-інкубатор і в Тернопільській області за підтримки Тернопільського обласного центру зайнятості [2].

Відповідно, за таких умов, коли надто мінімальний розвиток інноваційних процесів в діяльності малого бізнесу, коли майже відсутня підтримка впровадження інноваційних структур, - створюється досить невтішна ситуація на ринку. Молодь та молоді науковці за першої ж можливості звертаються до іноземних інвесторів за фінансовою допомогою, що звісно негативно впливає на розвиток технологій в нашій державі. Тому, однією із нагальних потреб $є$ створення бізнес структур на базі кожного університету, що буде надзвичайно ефективним для них. Адже кількість ВН3 на початок 2018 року становила 652 одиниці, а бізнес-інкубаторів, які діють при ВНЗ - лише приблизно 15-20 одиниць [3]. Саме це сприятиме розвитку науки й технологій в країні як для студентів, так і для вчених та викладачів, що стане також запорукою створення та успішного розвитку малих підприємств, які наразі не мають вагомої підтримки від держави.

У цілому формування і реалізацію державної політики підтримки і розвитку бізнесінкубаторів, як і усієї інноваційної інфраструктури, повинні забезпечувати органи державної влади і місцевого самоврядування всіх рівнів при взаємодії з науковцями та підприємцями.

Таким чином, інноваційна інфраструктура регіону повинна бути універсальною та сприяти створенню і розвитку інноваційних продуктів на конкурентоздатній основі. При чому, формуючи регіональну інноваційну інфраструктуру необхідно враховувати саме наявний потенціал підприємств малого бізнесу, регіону та ряд супутніх факторів, що мають прямий вплив на інноваційний розвиток.

\section{Перелік використаних джерел:}

1. UNESCO Institute of Statistics database [Електронний ресурс] - Режим доступу: http://data.uis.unesco.org

2. Тернопільська обласна державна адміністрація [Електронний ресурс] - Режим доступу: http://www.oda.te.gov.ua

3. Державна служба статистики України [Електронний ресурс] - Режим доступу: http://www.ukrstat.gov.ua/

4. Інноваційна Україна 2020: національна доповідь / за заг. ред. В. М. Геєця, А. І. Даниленка, Е. М. Лібанової [та ін.]. - К.: Експрес, 2015. - 336 с.

5. Стратегія інноваційного розвитку України на 2010-2020 роки в умовах глобалізаційних викликів [Електронний ресурс]. - Режим доступу: http://kno.rada.gov.ua/uploads/documents/36382.pdf 


\title{
СЕКЦІЯ 6. \\ СТРАХОВИЙ РИНОК УКРАЇНИ - КАТАЛІЗАТОР ЧИ СТРИМУВАЧ \\ ПРОГРЕСИВНИХ ЗМІН У ВІТЧИЗНЯНІЙ ЕКОНОМІЧНІЙ СИСТЕМІ?
}

УДК 368

\begin{abstract}
Гой Віта
студентка групи ПФ-21

Тернопільський національний технічний університет ім. І. Пулюя

м. Тернопіль, Україна

Науковий керівник: Тимошик Наталія кандидат економічних наук., доцент кафедри економіки та фінансів

Тернопільський національний технічний університет ім. I. Пулюя

Vita Hoi

student ПФ-21

Ternopil Ivan Puluj National Technical University

Ternopil, Ukraine

Scientific supervisor: Tymoshyk Nataliia

Candidate of Economic Sciences,

Associate Professor at the Department of Economic and Finance

Ternopil Ivan Puluj National Technical University

Ternopil, Ukraine
\end{abstract}

\section{КІБЕР-СТРАХУВАННЯ ЯК НОВИЙ ПРОДУКТ НА РИНКУ \\ СТРАХОВИХ ПОСЛУГ \\ CYBER-INSURANCE AS A NEW PRODUCT IN THE INSURANCE MARKET}

Розвиток процесів глобалізації та інтеграції приводить до появи нових видів ризиків, пов'язаних 3 кіберзагрозами й кібератаками. Зараз це набуло особливого поширення в багатьох країнах світу і посприяло необхідності впровадження нових систем кіберзахисту. В останні роки на міжнародному ринку став популярний новий вид страхування - кіберстрахування.

Кібер-страхування - це новий вид страхового продукту, який використовують для усунення ризиків, які стосуються інформаційних технологій, а саме захисту юридичних та фізичних осіб від ризиків користування Інтернетом.

Кібер-атаки спричиняють втрату корпоративних даних, інтелектуальної власності і баз даних клієнтів. Це у свою чергу має негативні наслідки для компаній, такі як: штрафи і втрата репутації, тому питання захисту внутрішньої інформації залишається дуже актуальним.

Основним завданням кібер-страхування $є$ захист від великомасштабної хакерської атаки. Цей вид страхування забезпечує фінансовий механізм відновлення після великих збитків, допомагаючи підприємствам повернутися до нормального функціонування, збереження стабільності, платоспроможності і зниження втрат у результаті перерви у виробництві [1].

Договір кібер-страхування покриває широкий спектр збитків. Даний вид страхування компанії від фінансових втрат у результаті DDoS атак, фішингу, кібер-вимагання, зараження шкідливим ПЗ, відповідальності за зберігання конфіденційної інформації та персональних даних. Особливістю є ще й те, що під страахове покриття потрапляє перерва у виробництві і 
втрата прибутку в результаті кібер-атак. Крім того, страхові компанії можуть пропонувати ще й інші, додаткові умови, як наприклад: відшкодування витрат на розслідування кіберзлочинів, антикризовий піар з метою відновлення репутації, витрати на захист в суді i відновлення роботи ІТ-систем.

Однією з основних причин розвитку кібер-злочинності як виду кримінального бізнесу $\epsilon$ значна прибутковість при незначних вкладеннях та виробничих затратах. Іншою причиною росту кібер-злочинності можна вважати незначні ризики при складності оперативнопошукових та слідчих заходів у разі скоєння кібер-злочину. Крім того, існує психологічний аспект кібер-злочинності: злочинці не знають об'єкти злочину (жертви) особисто, що припускає відсутність у них прояву почуття провини та стримування [2, с. 423-424].

Кіберстрахування є обов'язковим для тих, кому треба захищатись від хакерських атак. Це не лише хостинг-центри, IT-провайдери, розробники програмного забезпечення, але й будь-які фірми $з$ цінною інформацією клієнтів. Переважно, 9 з 10-ти компаній, які гублять ці електронні дані, оголошують про банкрутство протягом наступного року.

На світовому ринку послуги страхування від кібер-ризиків пропонують близько 60 страхових компаній. Особливого поширення даний вид страхування набув у США.

Доходи ринку кібер-страхування в 2017 році склали \$2,5 млрд., а до 2020 року вони повинні зрости до \$7,5 млрд., - повідомляє видання Anti-Malware з посиланням на РwC. При цьому $90 \%$ доходів поступили від американських компаній через зломи корпоративних $\mathrm{i}$ урядових ресурсів зробили цей вид страхування швидкозростаючим страховим продуктом в США [3].

В Україні, як і в інших країнах Східної Свропи, цей вид страхування ще не набув значного поширення. Для страховиків ця сфера залишається новою і ще не до кінця зрозумілою.

Останніми роками можна спостерігати збільшення кількості хакерських атак на українські організації. Це стосується як державних організацій, так і приватних компаній. 2017 рік ввійде в історію як рік з великою кількістю масштабних кібер-атак. За даними кіберполіції за 27 червня постраждало понад 2000 компаній. Це спричинило втрату внутрішньої фінансової документації, баз даних клієнтів, що у свою чергу спричинило значні матеріальні збитки. Тому з'явився інтерес да нового виду страхування - кібер-страхування i зростання попиту зі сторони страхувальників.

Українські страхові компанії не мають достатнього розуміння технічної специфіки страхування інформаційних ризиків. Для проведення справжнього технічного аудиту інформаційної безпеки в компанії, необхідно зробити серйозне дослідження, яке страховик просто не в змозі провести.

Необхідним $\epsilon$ удосконалення нормативно-правової бази, оскільки чинні нормативноправові акти у сфері протидії кібер-злочинності $\epsilon$ неузгодженими між собою. Відповідно потрібно вносити зміни, що стосуються кібер-страхування до Закону «Про страхування». На законодавчому рівні необхідно посилити кримінальну відповідальність, зокрема i працівників страхових компаній, за продаж інформаційних баз даних клієнтів, розкриття конфіденційної інформації. Що стосується системи страхування кіберризиків, то необхідно практично повністю виключити вплив людського фактора на розкриття інформації про страхувальників, створивши відповідні служби інформаційної безпеки i встановивши обмежений доступ працівників до їхніх баз даних 3 персональною відповідальністю виконавців.

Отже, страховий захист від кібер-ризиків має великі перспективи розвитку в Україні.

Перелік використаних джерел:

1. http://forbes.net.ua/ua/opinions/1426423-kiber-strahuvannya-novij-instrument-rizikmenedzhmentu

2. Віра П. Братюк. Сутність кібер-злочинів та страховий захист від кібер-ризиків в Україні // Актуальні проблеми економіки №9(171), 2015. - С. 421-427. 
3. https://forinsurer.com/news/17/02/28/34934

УДК 368

\begin{abstract}
Гула Інна
студентка групи ПФ-21

Тернопільський національний технічний університет ім. І. Пулюя

Науковий керівник: Тимошик Наталія кандидат економічних наук., доцент кафедри економіки та фінансів

Тернопільський національний технічний університет ім. І. Пулюя

Hula Inna

student of group ПФ-21

Ternopil Ivan Puluj National Technical University

Ternopil, Ukraine

Scientific supervisor: Tymoshyk Nataliia

Candidate of Economic Sciences,

Associate Professor at the Department of Economic and Finance

Ternopil Ivan Puluj National Technical University

Ternopil, Ukraine
\end{abstract}

\title{
ПРОБЛЕМА ОПОДАТКУВАННЯ СТРАХОВИХ КОМПАНІЙ В УКРАЇНІ THE PROBLEM OF TAXATION OF INSURANCE COMPANIES IN UKRAINE
}

На сьогодні Україна активно входить у ринкову систему. Розвиток ринкових відносин зумовлює посилення ролі страхових компаній, діяльність яких спрямована на правдиве відображення реального стану економіки та тенденцій іiі розвитку. Страховий ринок виступає тією системою, яка б забезпечувала стабільний розвиток та ефективну діяльність суб'єктів господарювання. Забезпечення сприятливих умов для розвитку страхової системи в Україні набуває досить важливого значення, адже наразі даний вид бізнесу не $\epsilon$ досить ефективним. Важливим аспектом, який впливає на цей розвиток $є$ сприятлива система оподаткування, яка давала б змогу повністю розкрити весь потенціал та важливість цього виду бізнесу в Україні.

Сьогодні можна відстежити досить часті зміни, які вносяться в нормативні бази та законодавство $з$ приводу податкової системи та методів оподаткування, зокрема страхових компаній. Тому така нестабільність та відсутність державних гарантій для інвестиційної діяльності уповільнюють розвиток страхового ринку.

В Україні основними документами, які регулюють розвиток страхових відносин $є$ такі як: Конституція України, Цивільний кодекс, Закони України, Міжнародні ратифіковані та підписані угоди.

Законодавча база регулювання страхових відносин почала формуватися у 1993 році. Тоді був прийнятий Декрет «Про страхування», який був створений на нормативній базі, яка регулювала діяльність Держстраху. Однак усі недоліки тих нормативних актів перенеслися частково на діяльність страхових компаній. Тому перед органами страхового нагляду стояло завдання удосконалити систему регулювання діяльності страхових компаній. Основним законом, який був прийнятий у 1996 став Закон України «Про страхування», редагований у 2001, 2006, 2011 і 2015 роках.

Буквально на два роки раніше був прийнятий Закон України «Про оподаткування прибутку підприємства», де об'єктом оподаткування виступав прибуток підприємства чи організації. 22 травня 1997 року були внесені зміни до цього закону, за яким змінювалася система оподаткування страхових компаній. Об'єктом оподаткування став валовий дохід від діяльності, який включав в себе страхові внески, страхові платежі та страхові премії.

На сучасному етапі розвитку основним документом, який регулює податкову систему $\epsilon$ Податковий кодекс. На початку 2015 року система оподаткування змінилася. Були запропоновані новації в усіх системах оподаткування у системах у 2018 році. Було запроваджено змішану систему оподаткування страховиків, відповідно до якої страхові 
компанії зобов'язані сплачувати податок у вигляді 3 \% від страхових платежів, внесків та премій, а також податок на прибуток, який страховик отримує від його діяльності (страхової, фінансової, тощо). Відповідно до цих змін зараз існує два об'єкти оподаткування: прибуток від страхової та нестрахової діяльності, що оподатковується за ставкою 18 \%.

Більшість страховиків незадоволені такими змінами і вважають їх дискримінаційними по відношенню до страхового ринку. Певна річ, що таке незадоволення $є$ цілком виправдане. На початках була ідея створення загальної системи оподаткування, а в результаті утворили подвійний податок. У результаті база оподаткування збільшилася майже втричі. Зважаючи й на те, що в Україні страхові компанії сплачують й інші податки (ССВ, наприклад), податкове навантаження на страховий бізнес значно зросло.

Безперечно, у країні, де страховий бізнес не $\epsilon$ досить ефективним, таке оподаткування не $\epsilon$ позитивним фактором. Порівнюючи нову систему оподаткування 3 старою, можна знайти переваги та недоліки, як старої системи, так і нової. Перевагою старої можна назвати прозорість системи оподаткування і простота розрахунків для органів перевірки. Недоліком було те, що податок сплачувався навіть при збитковості компанії. Що до плюсів нової системи, то перевагою $є$ те, що встановлена нульова ставка оподаткування страхових премій з добровільного медичного страхування.

Якщо порівнювати систему оподаткування країн Західної Європи і США, то можна знайти істотні відмінності. Незважаючи на те, що зараз активно проходять інтеграційні процеси на страхових ринках та, як правило, існують однакові підходи до оподаткування страхового бізнесу, у більшості країн переважають однакові індивідуальні рішення при виборі ставок та порядку сплати податків. Найважливішим інструментом регулювання страхового бізнесу $є$ спеціальний податок на страхову премію. При цьому об'єктом оподаткування виступають будь-які платежі, які здійснює страхувальник відносно страховика. Податок на страхову премію вважається абсолютно самостійним інструментом, а тому відокремлений від такий видів податку, як: податок на додану вартість та податок 3 обороту. Закордоном досить поширеною $є$ також пільгова практика оподаткування. Цим уряди європейських країн сприяють розвитку недержавного пенсійного страхування.

Аналізуючи політику оподаткування страхового ринку України, стає зрозуміло, що уряд сподіваючись зібрати більше податків, створив зовсім протилежний ефект. Зараз спостерігається збільшення податкових надходжень, проте, спираючись на факт, що рентабельність страхового бізнесу зараз низька, то цілком реальною $є$ та картина, що через деякий час кількість страхових компаній скоротиться, а деякі будуть затримувати виплати клієнтам.

Зараз важливо опиратися на досвід економічно розвинених країн світу, який засвідчує, що оптимальна система оподаткування $\epsilon$ найкращим способом стимулюванням розвитку будь-якої галузі. Для побудови ефективної системи оподаткування доцільно запровадити єдину ставку оподаткування. Найкращим способом оподаткування є стягнення податку 3 кооперативного прибутку страхової компанії. Основними принципами оподаткування мають стати такі, як: оподаткування має виконувати регулятивну функцію як основну; види та елементи податків мають регулюватися на національному рівні, а не на міжнародному; підхід до оподаткування має бути комплексним. Важливо також удосконалювати систему страхового нагляду, удосконалювати законодавство, що $\epsilon$ першоосновою для утворення дієвого механізму страхування.

Таким чином система оподаткування страхового бізнесу є недосконала, адже має багато недоліків. Для того, щоб визначити, яка система оподаткування буде найкращою для України, потрібно проводити комплексні розрахунки для визначення успішності чи краху тої чи іншої системи. Досить перспективним шляхом буде вибір диференційованої системи оподаткування, що зменшить частку страховиків, які приховують свої реальні прибутки. Можливо, цей не вирішить повністю проблем страхового ринку, однак дасть поштовх для розвитку страхування в Україні. А це в свою чергу буде захищати добробут людей та 
приносити прибуток за рахунок інвестицій тимчасово вільних грошей в перспективні проекти.

УДК 368.07

\author{
Михалочкіна Марина \\ магістр \\ Дніпровський національний університет імені Олеся \\ м. Дніпро, Україна \\ Науковий керівник: Бслозерцев Василь \\ доцент \\ Дніпровський національний університет імені Олеся \\ м. Дніпро, Україна \\ Marina Mihalochkina \\ master student \\ Oles Honchar Dnipro National University \\ Dnipro, Ukraine \\ Scientific supervisor: Vasil Bylozertsev \\ Associate Professor \\ Oles Honchar Dnipro National University \\ Dnipro, Ukraine
}

\title{
УМОВИ ВПРОВАДЖЕННЯ ТА РОЗВИТКУ СИСТЕМИ РИЗИК-МЕНЕДЖМЕНТУ \\ В СТРАХОВИХ КОМПАНІЯХ УКРАЇНИ \\ CONDITIONS OF IMPLEMENTATION AND DEVELOPMENT OF RISK MANAGEMENT SYSTEM IN UKRAINIAN INSURANCE COMPANIES
}

Діяльність страхових компаній безпосередньо пов'язана з різного роду ризиками. У відповідності до світової практики страховики розробляють власну страхову політику, що стосується конкретних ризиків, у відповідності до чого існує об'єктивна необхідність якісного та своєчасного управління цими ризиками.

Доцільність системного управління ризиками в страхових компаніях зумовлена безпосередньою природою їх прояву. Висока схильність страхових компаній до збитків, що негативно впливають на їх фінансову стійкість, свідчить про необхідність якісного управління ризиками. Зарубіжна практика свідчить про активне використання ризикменеджменту страховими компаніями. В Україні ризик-менеджмент в страховій галузі поки що не має належного розвитку, що обумовлено як організаційно-економічними передумовами, так і відсутністю достатньої методичної і методологічної бази [1].

При класифікації ризиків страхової компанії особливу увагу необхідно приділити ризикам, управління якими є основною методу ризик-менеджменту, а саме специфічним ризикам, які включають у себе технічні, нетехнічні і інвестиційні ризики. При цьому потрібно відмітити, що особливу увагу слід приділити класифікації, що розроблена Європейським комітетом по страхуванню.

Незважаючи на значну кількість методів та інструментів фінансового ризикменеджменту, багато 3 них мають деякі недоліки та не завжди можуть бути застосовані вітчизняними страховими компаніями. У зв'язку з цим значного розповсюдження набули показники EVA та RAROC, що враховують витрати на залучення позикового та власного капіталу. Ці показники надають можливість компаніям оцінити ризики, пов'язані 3 використанням капіталу та доцільність альтернативних вкладень компанії.

Потрібно відзначити, що головна мета розробки системи управління ризиками із застосуванням показники EVA та/або RAROC - це підвищення ефективності системи ризикменеджменту, а не просто точний розрахунок цих показників. EVA i RAROC відрізняються тим, що враховують витрати на залучення позикового i власного капіталу, тоді як використовувані в страхових компаніях показники не беруть їх до уваги. Ця особливість 
показників уможливлює аналіз ефективності використання капіталу в порівнянні 3 альтернативними варіантами вкладень.

Показник EVA використовується для оцінки ефективності довгострокової діяльності компанії і її окремих підрозділів. Тому даний показник доцільно було б використовувати для системи ризик-менеджменту українських страхових компаній. Можна виділити такі переваги використання EVA:

1. збільшення вартості, що є привабливим для інвесторів;

2. позитивне відношення з боку суспільства, що покращує продуктивність стратегії прискорення зростання;

3. націленість на результат завдяки мотивації;

4. корпоративне управління, покращує збільшення ефективності діяльності компанії та оптимізацію ризиків [2].

Крім того, додатковою перевагою даного показника $є$ те, що розрахунок не потребує важкодоступних даних і виконується на основі бухгалтерської звітності, що є досить привабливою можливістю для страховиків в сучасних умовах господарювання.

Досить поширеним методом ризик-менеджменту на сьогодні $є$ нормування, а саме встановлення вимог до обсягу статутного капіталу страховика, розміщення страхових резервів та інше. Цей метод дозволяє уникнути настання можливих ризиків страховика, завчасно встановити певні фінансові обмеження [3].

В Україні нормування реалізується через встановлення мінімального статутного капіталу, що становить один млн. євро для страхової компанії, що займається видами страхування, іншими, ніж страхування життя, та десять млн. євро для тих страхових компаній, що займаються страхуванням життя людей. Серед інших вимог існують також обмеження щодо організаційно-правової форми, правил страхування, здійснення фінансового моніторингу, тощо.

Як приклад нормування фінансового ризик-менеджменту, можна розглянути нормативи страховиків $\mathrm{CC}$ «Solvency II». Дані нормативи полягають у виокремленні трьох блоків показників, які підлягають вивченню при контролі діяльності страхових компаній 3 метою гарантування їх платоспроможності [3]. Однак для вітчизняних компаній впровадження європейських стандартів нормування $є$ проблемним питанням.

Організаційна система ризик-менеджменту вітчизняних страхових компаній може включати наступні послідовні елементи: створення робочих груп за участі експертів; виявлення ризиків на підставі встановлених цілей і фактично наявних процесів; оцінювання схильності та ранжування ризиків за суттєвістю.

Можемо зробити висновок, що ризик $є$ елементом розвитку та функціонування страхових компаній. В нашій країні системи ризик-менеджменту страхових компаній недостатньо розвинуті, що, в свою чергу, потребує адаптації складних теорій ризику і методів управління ризиком до практичної діяльності вітчизняних страхових компаній.

\section{Перелік використаних джерел:}

1. Е and Y: 10 ключових ризиків страхової галузі. [Електронний ресурс]. - Режим доступу: http://www.insurance.lviv.ua

2. Журко Т. В. Меры по снижению рисков страховых компаний / Т. В. Журко // Аудит и финансовый анализ. - 2010. - № 1. - С. 3-5.

3. Ткаченко Н. В. Переваги Solvency II для основних учасників страхового ринку / Н.В. Ткаченко //Банківська система України в умовах глобалізації фінансових ринків: зб. тез VII Міжнародної науково-практичної конференції. - Черкаси: ЧІБС УБС НБУ, 2017. - с. 5459. 


\begin{abstract}
Михно Наталія
студент групи ПО-21
\end{abstract}

Тернопільський національний технічний університет імені Івана Пулюя

м. Тернопіль, Україна

Малинич Ганна

к.е.н.

ст. викладач кафедри економіки та фінансів

Тернопільський національний технічний університет імені Івана Пулюя

м. Тернопіль, Україна

Nataliia Mykhno

student of group ПО-21

Ternopil Ivan Puluj National Technical University

Ternopil, Ukraine

Hanna Malynych

$\mathrm{PhD}$ (Economics),

Ternopil Ivan Puluj National Technical University

Ternopil, Ukraine

\title{
РИНОК СТРАХУВАННЯ ЖИТТЯ В УКРАЇНІ ТА ЙОГО ІНДИКАТОРИ LIFE INSURANCE MARKET IN UKRAINE AND ITS INDICATORS
}

Страховий ринок є важливою складовою ринку фінансових послуг, функціонування якого забезпечує не лише розподіл та перерозподіл ризиків в економіці, а й грошових та інвестиційних потоків між суб'єктами.

Розвиток вітчизняного ринку страхування супроводжується низкою стримуючих факторів, зокрема до них можна віднести проблеми формування нормативно-правової бази, пов'язані з гармонізацією фінансового законодавства Європейського Союзу, низький попит фізичних і юридичних осіб на страхові послуги, спричинений низьким рівнем доходів домогосподарств та незадовільним рівнем фінансової культури, та інші проблеми, що притаманні іншим секторам фінансового ринку.

Ринок страхових послуг є другим за рівнем капіталізації серед інших небанківських фінансових ринків. Загальна кількість страхових компаній станом на 30.09.2018 становила 285, у тому числі СК «life» 1 - 31 компанія, СК «non-life» - 254 компанії, (станом на 30.09.2017 - 296 компаній, у тому числі СК «life» - 34 компанії, CK «non-life» - 262 компанії). Кількість страхових компаній має тенденцію до зменшення, так за 9 місяців 2018 року порівняно з аналогічним періодом 2017 року, кількість компаній зменшилася на 11 $\mathrm{CK}[1]$.

Важливим індикатором розвитку ринку страхування є співвідношення між ринком ризикового страхування та ринком страхування життя за розміром страхових премій. Вважається, що висока питома вага ринку страхування життя є достатньо інформативним показником не лише страхового ринку, а й економіки країни в цілому, оскільки відображає рівень забезпеченості фізичних осіб страховим захистом, а економіки країни інвестиційними ресурсами.

Рівень покриття страховим захистом в Україні сягає 5-7\% населення, в Європі цей показник сягає 80-85\%. Витрати на страхування життя на душу населення в Україні становить 1,5 - 2 \$, натомість у Великобританії - 3300 \$, США - 1750 \$, Німеччині - 1042 \$, Угорщині - 148 \$, Польщі - 102 \$, Румунії - 14,6 \$, Росії - 6,3 \$.

На думку дослідників причинами несприятливої ситуації є: тотальна недовіра до всіх фінансових установ в Україні; відсутність підтримки страхування життя на державному рівні, високий рівень монополізації ринку страхування життя іноземними страховими компаніями. Так, по ринку страхування життя Індекс Герфіндаля - Гіршмана (ННI) склав 1 
445,23 (за 9 місяців 2017 року - 1 424,91), по ринку ризикових видів страхування становив 248,57 (за 9 місяців 2017 року - 305,70). В цілому по страховому ринку індекс Герфіндаля Гіршмана склав 219,96 (за 9 місяців 2016 року - 273,50) [1].

Перспективи розвитку ринку страхування в Україні залежатимуть від подальшого удосконалення законодавчої бази, що регулює не тільки сферу страхування, а і загалом всі види діяльності, зокрема розвитку недержавного пенсійного страхування, страхування життя, медичного страхування, іпотечного кредитування, діяльності банків та їх впливу на страхування, а також від створення сприятливої системи функціонування інституту страхових посередників, покращення страхової культури та підвищення довіри до страховиків.

Перелік використаних джерел:

1. Підсумки діяльності страхових компаній за 9 місяців 2018 року. - Режим доступу: https://forinsurer.com/files/file00647.pdf

УДК 368.01

Ожібко Мар'яна

3-ПТБ-134/11

ДВНЗ «Тернопільський коледж харчових технологій і торгівлі»

Тернопіль, Україна

Науковий керівник: Обуд Оксана

викладач-методист

ДВНЗ «Тернопільський коледж харчових технологій і торгівлі»

аспірант кафедри маркетингу ТНЕУ

Mariana Ozhibko

3-PTB-134/11

«Ternopil College of Food Technologies and Trade»

Ternopil, Ukraine

Scientific superviser: Oksana Obud

Teacher-Methodist of the State Higher Educational Institution

Ternopil, Ukraine

College of Food Technologies and Trade

post - graduate student of the Department of Marketing of TNEU

\section{ПРОБЛЕМИ ТА ПЕРСПЕКТИВИ РОЗВИТКУ СТРАХОВОГО РИНКУ УКРАЇН \\ PROBLEMS AND PROSPECTS FOR DEVELOPMENT OF UKRAINE'S INSURANCE MARKET}

Сучасні процеси в економіці країни потребують економічних реформ, що в свою чергу обумовлює необхідність розвитку страхового ринку. В умовах сьогодення важливим $\epsilon$ формування ефективної системи інструментарію, спрямованого на збільшення рівня конкурентоспроможності страхових компаній та надання конкурентних послуг не лише на внутрішньому, а й зовнішньому ринках [1].

Страхові компанії самостійно будують свою фінансово-економічну політику i концепції розвитку, розробляють внутрішні фінансові механізми, що сприяють на результативність компанії. В умовах становлення та розвитку страхового ринку, для того, щоб страхові компанії змогли ефективно та надійно функціонувати, мати економічну спроможність необхідно проводити бізнес-планування та прогнозування діяльності. Для цього необхідне застосування сучасних методів економіко-математичного моделювання, а 
саме методів кореляційно-регресійного аналізу, математичного програмування, сучасних технологій імітаційного моделювання та ін. [2].

Місце страхового ринку у фінансовій системі обумовлено як роллю різних фінансових інститутів у фінансуванні страхового захисту, так і їх значенням як об'єктів розміщення інвестиційних ресурсів страхових організацій і обслуговування страхової, інвестиційної та інших видів діяльності [3].

Специфіка страхування визначає безпосередній зв'язок страхового ринку з фінансами підприємств, фінансами населення, банківською системою, державним бюджетом та іншими фінансовими інститутами, в рамках яких реалізуються страхові відносини[6].

Страховий ринок в Україні все ще перебуває на початковому етапі розвитку, окремі його сегменти стрімко розвиваються, проте рівень страхового покриття залишається на низькому рівні (він складає лише 3-5 \%, тоді як у країнах Західної Свропи - понад 95 \%). У нашій країні розвиваються лише класичні види страхування - КАСКО, майнове страхування, страхування цивільної відповідальності тоді як, наприклад, медичне страхування знаходиться на етапі зародження. Це обумовлено, в першу чергу, рівнем доходів населення. В зв'язку з нестабільною політичною та економічною ситуацією в державі, погіршилося становище страхового ринку.

Основними проблемами, що стримують розвиток страхового ринку є [4]: недосконала нормативно-правова база низький попит фізичних і юридичних осіб на страхові послуги, що спричинено економічною та політичною кризою в країні; відсутність надійних інвестиційних програм, а також реальних фінансових механізмів для довгострокового розміщення страхових резервів; низький рівень страхових виплат; низький рівень дохідності окремих видів страхування; недостатня ефективність стратегічного менеджменту страхових компаній; значна інформаційна закритість діяльності страхових компаній; політична нестабільність в країні; слабкі зовнішньоекономічні зв'язки України у сфері страхування з іншими країнами; нерозвиненість національної страхової інфраструктури; недостатній рівень і потенціал розвитку страхування за межами країни; низькі показники конкурентоспроможності українських страхових компаній. Частина 3 цих проблем $є$ притаманними i для інших секторів фінансового ринку (наприклад, проблеми економічного характеру й організаційноправові проблеми), інша частина характерними лише для страхового ринку. Велика кількість цих проблем пояснюються передусім прагненням страхових компаній максимізувати прибуток, незважаючи ні на довгострокові інтереси галузі, ні на професійну етику [7].

В Україні сьогодні, також, актуальним залишається питання розвитку страхового захисту як окремого напряму державного регулювання розвитку бізнесу і підприємництва в різних галузях народного господарства, тобто шляхом прийняття спеціальних законів, визначення обов'язкових видів страхування, регламентації діяльності страхових організацій. Для того, щоб на українському страховому ринку покращилась ситуація необхідно впроваджувати такі заходи: відновлення довіри населення до страховиків, що вимагає серйозних, зрозумілих для потенційних клієнтів, гарантій повернення вкладених коштів і нарахованих на них відсотків; посилення контролю за діяльністю страховиків з боку органів страхового нагляду, застосування ними своєчасних заходів, які попереджують неплатоспроможність страховиків; створення нормативної бази, яка регулює права, обов'язки та відповідальність сторін за договорами перестрахування; стабілізація фінансового стану всіх суб'єктів економіки та населення; удосконалення організаційної структури та створення інфраструктури страхового ринку на рівні світових вимог; розвиток системи перестрахування і та ін. [8].

Перспективи розвитку ринку страхування в Україні залежатимуть від подальшого удосконалення законодавчої бази, що регулює не тільки сферу страхування, а і загалом всі види діяльності, зокрема розвитку недержавного пенсійного страхування, страхування життя, медичного страхування, іпотечного кредитування, діяльності банків та їх впливу на страхування, а також від створення сприятливої системи функціонування інституту 
страхових посередників, покращення страхової культури та підвищення довіри до страховиків [6].

Страховим компаніям необхідно підвищувати ефективність страхового менеджменту, застосовуючи економіко-математичний інструментарій та сучасні технології імітаційного моделювання. Це дозволить визначити ступінь активності реагування компанії на зміни страхового ринку з метою своєчасного прийняття відповідних заходів; оцінити ефективність технології формування технічних резервів та загальних активів компанії; спрогнозувати можливі зміни іiї фінансового становища; визначити прогнозні значення головних кінцевих показників діяльності страховика. Застосування у страховому менеджменті кількісних моделей дозволить оцінити об'єктивно-необхідний рівень витрат на управління, можливості проведення інвестиційної політики, визначити стратегію проведення маркетингової політики [5].

Отже, впродовж останніх років ситуація на ринку страхових послуг України склалася не зовсім сприятлива. Негативні наслідки кризи призвели до уповільнення темпів росту доходів страхових компаній, зменшення попиту населення на страхові послуги. Поряд 3 цим вітчизняний страховий ринок має значний потенціал розвитку, важливим є створення умов та нових можливостей у його розвитку.

\section{Перелік використаних джерел:}

1. Клепікова О. А. Дослідження динаміки розвитку страхового ринку України як складової світового ринку страхових послуг / О.А. Клепікова // Вісник Одеського національного університету. Економіка. - Одеса: Астропринт, 2010. - Т. 15. - Вип. 20. C. 101-111.

2. Машина Н.І. Міжнародне страхування. Навчальний посібник, К. -Центр учбової літератури, 2006. $-480 \mathrm{c}$.

3. Клепікова О. А. Моделювання маркетингової стратегії страхової компанії / О. А. Клепікова // Вісник Київського національного університету ім. Т. Г. Шевченка. Економіка. - 2013. № 6(147). с. 55-60.

4. Александрова М. М. Страхування: навчально - методичний посібник. - К.: ЦУЛ, 2002. $-280 \mathrm{c}$.

5. Соколовська 3. М. Прикладні моделі системної динаміки: [монографія] / 3. М. Соколовська, О. А. Клепікова. - Одеса: Астропринт, 2015. 308 с.

6. Тулуш Л. Д. Сучасний стан і перспективи розвитку страхового ринку в Україні / Л. Д. Тулуш, Ю. С. Воскобійник. [Електронний ресурс]. - Режим доступу: http://udau.edu.ua/library.php.

7. Стратегія розвитку страхового ринку України на 2011-2020 роки [Електрон. pecypc]. - Режим доступу: http://ufu.org.ua/ua/about/activities/strategic initiatives/5257.

8. Говорушко Т. А. Страхові послуги: навчальний посібник / Т. А. Говорушко. - Київ: Центр навчальної літератури, 2005. - 400 с. 


\title{
СЕКЦІЯ 7. \\ ЕКОНОМІЧНО ЕФЕКТИВНА ТОРГІВЛЯ: РОЗУМІННЯ СУТІ ТА СУЧАСНІ ПІДХОДИ ДО ЇЇ ВЕДЕННЯ
}

УДК 339.17

\begin{abstract}
Гундерук Тетяна
студент групи ПО-21

Тернопільський національний технічний університет імені Івана Пулюя

м. Тернопіль, Україна

Hunderuk Tetiana

student of group ПО-21

Ternopil Ivan Puluj National Technical University

Ternopil, Ukraine

Малинич Ганна

к.e.H.

ст. викладач кафедри економіки та фінансів,

Тернопільський національний технічний університет імені Івана Пулюя

м. Тернопіль, Україна

Malynych Hanna

$\mathrm{PhD}$ (Economics)

Ternopil Ivan Puluj National Technical University Ternopil, Ukraine
\end{abstract}

\section{ТРАНСФОРМАЦІЯ ФОРМ ТОРГІВЛІ: ВІД ВИТОКІВ ДО СУЧАСНОСТІ TRANSFORMATION FORMS OF TRADE: FROM CURRENCIES TO MODERN}

В умовах швидкого розвитку суспільства, здобутків науково-технічного прогресу, інтеграційних процесів, змінюються абсолютно всі сфери життя. Постає питання: «Що таке економічно-ефективна торгівля, і чи можлива вона взагалі?». Відповідь на це запитання $€$ об'єктом пошуку багатьох науковців.

Поняття торгівлі є достатньо дослідженим і розглядається як процес обміну товарами, послугами, цінностями і грошима або вид підприємницької діяльності, пов'язаний 3 купівлею-продажем товарів.

Торгівля виникла ще на етапі первісно-общинного ладу. Певні домогосподарства стали виготовляти товари не тільки для власного вжитку, але що б і обмінювати їх на інші товари. Однією з причин виникнення торгівлі також можна назвати суспільний поділ праці. Широкого розповсюдження торгівля набула при появі і розвитку міст.

У Київській Русі велася активно як внутрішня так і зовнішня торгівля. Внутрішня торгівля зосереджувалася по містах, де були «торги», «торговища», зокрема в Києві (1017 р.) нараховувалось вісім торговельних майданів. Суб'єктами зовнішньої торговельних відносин виступали бояри, князі, купці. Київська Русь славилась своїми торговельними шляхами (найвідоміший шлях - «із варяг у греки»), саме це і було головним фактором стрімкого розвитку торгівлі на українських землях у X-XIII ст. [2].

Форма торговельних відносин змінювалися під впливом розвитку економічних систем та науково-технічного прогресу, відбувся перехід від особистих форм торгівлі до дистанційної торгівлі, ці форми використовуються одночасно і не виключають одна одну, лише зазнає змін їхня структура.

Перехід від індустріального до інформаційного суспільства, що грунтується інформаційних і телекомунікаційних технологіях призвів до подальшого розвитку видів дистанційної форми торгівлі. Завдяки технологічному прогресу в такому суспільстві 
оброблення, накопичення, отримання і обмін інформацією в будь якій ії формі - звуковій, письмовій або візуальній - а не обмежені за відстанню, часом і обсягами. Інформаційна революція примножила можливості людського інтелекту і створила ресурси, що змінили спосіб суспільної праці і суспільного життя [1]. Розвиток Інтернету стає невід’ємною частиною ведення комерційної діяльності та забезпечив появу електронного бізнесу.

Розвиток електронної комерції дозволив підвищити ефективність торгівлі за рахунок зниження витрат на утримання торговельних майданчиків, забезпечення широкого асортименту, зручності пошуку товарів без відвідування магазинів тощо. Однак, ця форма торгівлі непозбавлена недоліків як для покупця, так і продавця: необхідність сплати авансу, час очікування отримання товари, ризик перехоплення особистої інформації по каналах зв'язку тощо.

Що таке економічно-ефективна торгівля, та як їі можна досягнути? - універсального рецепту успіху немає, проте, варто так би мовити, «тримати руку на пульсі» суспільного життя.

\section{Перелік використаних джерел:}

1. Європа та Глобальне інформаційне суспільство. Рекомендації Європейській раді. Брюссель, 26 травня 1994 р. (Europe and the Global Information Society. Recommendations to European Council. Brussels, 26 May 1994) // Європа на шляху до інформаційного суспільства: матеріали Європейської Комісії 1994-1995 pp. ; Держ. ком. зв’язку та інформатизації України. - К., 2000.

2. Полонська-Василенко Н. Історія України: У 2 т. Т. 1. До середини XVII століття. — 3-тє вид. - К.: Либідь, 1995. - 672 с.

\section{УДК 339.1}

Рудюк Ірина

студентка групи ПП-42

Тернопільський національний технічний університет імені І. Пулюя

м. Тернопіль, Україна

Iryna Rudiuk

Student of the group ПП-42

Ternopil Ivan Puluj National Technical University

Ternopil, Ukraine

Бажанова Наталія

доцент кафедри економіки та фінансів

Тернопільський національний технічний університет імені І. Пулюя,

м. Тернопіль, Україна

Student of the Faculty Economics and Management

Bazhanova Nataliia

Ph.D. (Economics), Associate Professor

Department of Economics and Finance

Ternopil Ivan Puluj National Technical University

Ternopil, Ukraine

\section{ТОРГІВЛЯ МАЙБУТНЬОГО: ПРОБЛЕМИ ТА ПЕРСПЕКТИВИ TRADE OF FUTURE: CHALLENGES AND PROSPECTS}

Актуальність. У сучасному світі все більше набирає популярності інтернет-шопінг. $61 \%$ населення України використовує інтернет регулярно, тобто $2 / 3$ країни сидить в мережі. За 2018 рік частка онлайн-продажів збільшилась приблизно на $30 \%$. Люди вважають це 
швидким, дешевим та надійним способом отримати бажані товари та послуги. Сьогодні існування роздрібної торгівлі вже просто неможливо без новітніх технологій. Так, ведення сучасного складу, в якому зберігаються іноді десятки тисяч видів різних товарів, вже просто неможливе без спеціального програмного забезпечення. Стало простіше управляти персоналом, взаємодіяти з постачальниками, займатися управлінням на виробництві та у фінансовій сфері. А тим часом з'являються все новіші технології, призначені для ефективного вирішення ще складніших завдань.

Виклад основного матеріалу. Генеральний директор Yakaboo.com Іван Богдан вважає, що маржинальна, рентабельність такого бізнесу становить від 30 до 50 \%. Найчастіше товари купують за допомогою смартфонів. Телефон стає єдиним пристроєм для пошуку і покупок. Тому є велика проблема у звичайних магазинів. Якщо люди купуватимуть товари в інтернеті, то постає питання: «що робити з приміщеннями?». Під час презентації продуктів Apple у 2017 році, президент компанії зазначив «Ми більше не називаємо їх магазинами - це «міські площі». Вони планують зробити своєрідне місце зустрічей, де можна не лише купити товари, а й провести час. У свою чергу, компанія Nordstrom має намір відкрити магазин Nordstrom Local, де будуть представлені SPA-сервіси, послуги кравця, стилістів, бар, але можливості купити одяг чи інші товари не буде. Поняття магазин як емоція, яке формує майбутнє торгівлі, не є інновацією. Це повернення до минулого. Професор історії Трейсі Дойч стверджує, що після Другої світової війни ідею громадських площ використовували великі торгові центри. У XIX столітті власники універсальних магазинів також орієнтувались на те, щоб справити враження на покупців. У магазинах були чайні кімнати, кафе, персонал, який повинен донести куплені товари. Причиною цього було нечасте відвідування магазинів.

Також важливим внеском у торгівлі було створення штучного інтелекту. Футуролог, доктор економічних наук Андрій Длігач вважає, що до 2025 року понад $50 \%$ доходів в торгівлі буде надходити від людей, які не орієнтуються на бренди, а до 2020 року люди почнуть забувати про торгові марки і почнуть покладатися на комунікацію 3 клієнтом, для якої буде використаний штучний інтелект. Великі компанії вже використовують CRMсистеми, які аналізують покупців і підбирають відповідні пропозиції. Описи товарів також складаються штучним інтелектом. У США магазини одягу використовують алгоритми, які мають здатність проаналізувати емоційний стан людини.

Великі українські компанії не відстають у цьому. Длігач зазначає, що до 2022 року даних, зібраних «Киівстаром», «ПриватБанком», «Сільпо» буде достатньо для створення компромату.

Висновок. Розвиток новітніх технологій стане основою для розвитку економіки в Україні та світової економіки в цілому у майбутньому.

\section{Перелік використаних джерел:}

1. Глущенко Н. Искусственный интеллект вместо брендов. [Електронний ресурс]. - Режим доступу : https://politeka.net/ua/news/hightech/748008-torgovlja-budushhego-staloizvestno-kak-iskusstvennyj-intellekt-zastavit-ljudej-zabyt-o-brendah/

2. Workabox. Роздрібна торгівля учора i сьогодні. - Режим доступу : http://workabox.ua/school/roznichnaya-torgovlya/ 
Хвостіков Андрій

здобувач, Харківський національний економічний університет імені Семена Кузнеця

Andrii Khvostikov

applicant, Simon Kuznets Kharkiv National University of Economics

\section{СУТНІСТЬ МІЖНАРОДНИХ ТОРГІВЕЛЬНО-ЕКОНОМІЧНИХ ВІДНОСИН В АГРАРНОМУ СЕКТОРI \\ ESSENCE OF INTERNATIONAL TRADE-ECONOMIC RELATIONS IN THE AGRICULTURAL SECTOR}

В сучасних умовах відкритої економіки, де тенденції глобалізації та інтеграції набувають все більшого розмаху, все більше країн активно займаються зовнішньою торгівельно-економічною діяльністю, що відображається у стабільному зростанні обсягу експортно-імпортної діяльності, збільшені обсягу та географічній диверсифікації трудової міграції, активній експансії капіталу з розвинутих країн в країни, які розвиваються. Іншим проявом інтеграції є розвиток міжнародних регіональних інтеграційних об'єднань, до яких відносяться НАФТА, ШОС, БРІКС та ЄС. Географічна та культурна близькість Європейського союзу з урахуванням поточного стану взаємовідносин 3 північним сусідом України обумовлюють необхідність подальшої інтеграції нашої держави саме до цього об'єднання, що і є найважливішим геополітичним вектором нашої держави. Для успішної подальшої інтеграції України в європейську спільноту важливим виступає розвиток торговоекономічних відносин 3 державами цього об'єднання, що можливо шляхом підвищення обсягу участі вітчизняних товаровиробників у світовій торгівлі з відповідною підтримкою 3 боку державних інститутів. Кожна галузь вітчизняної економіки відіграє свою роль в даному процесі, що і вимагає розробки методологічного та методичного забезпечення підвищення залученості підприємства 3 урахуванням специфіки їх діяльності. Важливість аграрного сектору в процесі зростання його залучення до світової торгівлі обумовлена збільшенням питомої ваги в експорті продукції рослинництва, що свідчить про існуючий попит на цю продукцію на світовому ринку та потенційні можливості збільшення присутності вітчизняних товаровиробників за кордоном.

Незважаючи на велику кількість досліджень у сфері міжнародних економічних відносин, зовнішньоекономічної діяльності, міжнародної торгівлі безпосередній зміст міжнародних торговельно-економічних відносин представлений лише в окремих дослідженнях, а відомі дослідники в даній галузі не зосереджуються на визначенні розбіжностей між торгівельно-економічними відносинами та діяльністю.

Так, А. П. Голіков та О. А. Довгаль визначають їх як відносини між державами або інтеграційними об'єднаннями, які засновані на обмінних та фінансових операціях, а також кооперації та спільному розвитку [1, с. 384].

P. I. Хасбулатов визначає міжнародне торгово-економічне співробітництво як весь обсяг торгових, виробничо-економічних, фінансових зв'язків і відносин в області торгівлі товарами і послугами за межами національних кордонів, міграції робочої сили. Визначаючи дане визначення ширшим ніж міжнародна торгівля, автор не визначає принципових відмінностей між ними [2].

Є. Ф. Авдокушин характеризує міжнародні економічні відносини як економічні зв'язки між суб'єктами господарювання різних країн та механізм реалізації цих зв'язків [3, с. 13].

Узагальнюючи існуючі навчальні праці закордонних (Є.Ф.Авдокушин, Є. Л. Александров, С. А. Дашкевич, Л. А. Кривенцов, В. Н. Круглов, Д. Г. Малашевич, Ю. В. Мелешко, Ф. З. Мічуріна, Т. Г. Мотовіц, Н. А. Овчаренко, Е. С. Пономарьова, В. Є. Рибалкін, Л. Є. Стровский, О. В. Тахумова, О. Є. Тітова, П. С. Томілов, Р. І. Хасбулатов) та вітчизняних (I. В. Амеліна, М. І. Барановська, С. В. Владимиров, А. П. Голіков, О. А. Гриценко, I. І. Дахно, О. А. Довгаль, Т. М. Камінська, Ю. Г. Козак, Н. С. Логвінова, Т. Л. Попова, 
В. І. Романчиков, І. О. Романенко, Л. С. Шевченко, Т.В. Шталь) науковців, варто зазначити, що міжнародну економіку розглядають як окремо, так і разом, але питання, які розглядаються в даній сфері є подібними. Так формами міжнародних економічних відносин більшість із зазначених авторів вважають, по-перше, міжнародну торгівлю, які об'єднує всі експортноімпортні операції між країнами в рамках зовнішньоекономічної діяльності як суб'єктів господарювання (переважно), так і держав, що включає торгівлю товарами та послугами; подруге, міжнародну трудову міграцію, яка за останні роки внаслідок існуючих геополітичних процесів набула значного масштабу, відчутно впливаючи на рівень розвитку держав через збільшення навантаження на робочі місця та зростання конкуренції за вигідні умови праці, а також через соціальне навантаження на бюджет внаслідок виплат по безробіттю, яке напряму залежить від стану ринку праці; по-трете, міжнародний ринок капіталу та валютнофінансових відносин, який включає платіжний баланс країни, світову валютну систему, валютний курс та режими його регулювання, міжнародне кредитування та міжнародні кредитні відносини; по-четверте, міжнародну інвестиційну діяльність, яка включає поряд 3 міжнародними інвестиціями політику стимулювання інвестиційної діяльності шляхом залучення в країну іноземних інвестицій; по-п'яте, міжнародний науково-технологічний обмін та останнє - регулювання міжнародних економічних відносин на національному та міжнародному рівнях, які включають діяльність відповідних організацій. Як бачимо ці форми безпосередньо залежить від предмету взаємодії між сторонами. Іншим аспектом торгів міжнародних торговельно-економічних відносин є сторони взаємодії, відповідно до яких ці відносини розрізняють на таких рівнях: мікрорівень передбачає взаємодію суб'єктів господарювання різних країн, що входять до здійснення зовнішньоекономічної діяльності, макрорівень передбачає взаємодію на державному рівні між державними установами та урядами різних країн, мегарівень або глобальний відображає відносини між інтеграційними об'єднаннями в рамках світової взаємодії. Враховуючи адміністративно структуру нашої держави та країн Європи варто виокремити мезорівень взаємодії, який передбачає співробітництво на рівні окремих регіонів та областей між відповідними органами виконавчої влади та місцевого самоврядування.

Аграрний сектор представлений галузями рослинництва та тваринництва, який є цілісним комплексом, як слушно зазначають автори [4], пов'язаний з природними умовами, ресурсами, технічними можливостями та персоналом.

Ефективність діяльності підприємств даної сфери пов'язана саме 3 кооперацією, що передбачає використання продуктів однієї галузі в іншій. Міжнародні торгово-економічні відносини в даній сфері представлені переважно експортно-імпортною діяльністю в торгівлі товарами та окремими проектами науково-технічного партнерства.

\section{Перелік використаних джерел:}

1. Голіков А. П. Міжнародні економічні відносини : підручник / А. П. Голіков, О. А. Довгаль. - Х. : ХНУ імені В. Н. Каразіна, 2015. - 464 с.

2. Хасбулатов Р. И. Международные экономические отношения 2-е изд., пер. и доп. ... Международные экономические отношения : учебник для бакалавров / Р. И. Хасбулатов. - 2-е изд., перераб. и доп. - М. : Издательство Юрайт, 2014. - 991 с.

3. Авдокушин Е.Ф. Международные экономические отношения: Учеб. пособие / Авдокушин Е. Ф. - М.: Маркетинг,1997. - 194 с.

4. Волошанюк Н. В. Аграрний сектор України: тенденції, суб'єкти, перспективи реформування / Н. В. Волошанюк, А. К. Сьомка // Науковий вісник Ужгородського національного університету. Серія : Міжнародні економічні відносини та світове господарство. - 2017. - Вип. 13(1). - С. 45-49. 


\title{
СЕКЦІЯ 8. \\ МАЙБУТНС КОНКУРЕНТОСПРОМОЖНОСТІ: РОЗУМНЕ УПРАВЛІННЯ, РОЗУМНІ ТЕРИТОРІЇ, РОЗУМНИЙ БІЗНЕС
}

\author{
Daniel Sarpong Mensah \\ Student of group IEE-33 \\ Ternopil Ivan Puluj National Technical University, Ternopil, Ukraine \\ Scientific supervisor: Iryna Kramar \\ Associate Professor, $\mathrm{PhD}$ \\ Ternopil Ivan Puluj National Technical University, Ternopil, Ukraine
}

\section{SMART BUSINESS PROCESS MANAGEMENT AS A TOOL FOR ECONOMIC DEVELOPMENT}

The digital transformation is altering governance models in a disruptive way. Governance is the enabling environment that requires adequate legal frameworks and efficient processes to enable the responsiveness of government to the needs of citizens [1]. Governance can also be defined as interaction and collaboration of different stakeholders in decision-making processes.

The abstract is focused on prudent management as a newly created area of research, attracting significant scientific and political attention. The abstract provides shows different views on smart governance and concepts such as smart and electronic governance in the context of smart territory. Smart Governance is suggested to be defined as "the capacity of employing intelligent and adaptive acts and activities of looking after and making decisions about something" [1]. Research shows that smart government can be considered as the basis for developing smart governance through the use of new information and communication technologies (ICTs) for government. Smart governance, such as the reasonable use of ICTs to improve decision-making through better partnership between different stakeholders, including government and citizens, can be closely linked to government approaches. In this case, ICT-based tools such as social networking and other platform can be factors that increase citizen participation and support the development of new governance models for smart government. Smart governance can also play a very vital role in logical city initiatives that require complex interactions between governments, citizens and other stakeholders.

Over the years there has been enormous debate about economic, social and regional development within a territory to become a smart one, due to the fact that there are ongoing revolution throughout in construction connected with eco-friendly buildings; in public transport, by optimizing traffic management and using energy-efficient vehicles; and through eco-responsible neighborhoods. To do this, all of the stakeholders involved (construction companies, transportation operators, energy resource managers, local authorities, developers, telecoms operators, etc.) must transform their services and products to improve the living standards of residents, tourists and workers within the city, county or region.

The term Smart Business Networks refers to an emerging concept for the agile composition of e-business value chains and a new stream of research, combining Management and Computer Science. It is interesting to observe the move from e-commerce to e-business, to the Internet-based integration of business processes it thus sometimes comes along with an information of entire value chains - in several industries - from the initial supplier to the final consumer.

Now is the time that IT governance stakeholders start thinking about enter-prise application integration strategically, top-down, instead of techno-logically, bottom-up. We foresee a completely new quality of IT to support the value-adding processes in modern enterprises by the systematic 
integration of BPM technology, knowledge management technology and social software. In enterprises, all the value-adding processes, both the formal, strictly organized and the informal, social are subject to management and IT support. We can distinguish between several horizontal fields of management, e.g., business process management, project management and knowledge management, and several vertical levels of management, e.g., strategy, tactics and operations. It is important to understand the huge potential of systematic integration of these fields and levels. Many important IT initiatives in the past aimed at overcoming information and control flow barriers between these management fields and levels. We want to characterize a conceptual level of thinking about IT integration and we use the term smart business process management for this. We give three examples, where the smart business process management perspective can help to design a new quality of IT support in modern enterprises: smart business continuity management, smart IT service management and smart production [2].

It is defined that smart governance is an emerging domain of study that attracts significant scientific and policy attention. We have found that the development of e-government and therefore the use of ICT for purposes mainly related to improving administrative efficiency, performance, citizen-centricity and improved service delivery, is the foundation for the development of a smart government. When smart business is properly used, it will provide a smooth and transparent integration of millions of resources and services on a worldwide scale.

\section{References:}

1. Scholl \& Alawadhi, Smart governance as key to multi-jurisdictional smart city initiatives: The case of the eCityGov Alliance, 2016. Available at: https://www.researchgate.net/publication/293808081_Smart_governance_as_key_to_multijurisdictional_smart_city_initiatives_The_case_of_the_eCityGov_Alliance.

2. Vervest P., Van Heck E., Preiss K., Pau L. (eds) Smart Business Networking / P. Vervest, E. Van Heck, K. Preiss, L. Pau // Springer Verlag, 2005.

Profesor Wydziału Ekonomii i Finansów Narodowy Uniwersytet Techniczny im. Iwana Puluja w Tarnopolu, Tarnopol, Ukraina

Halyna Tsikh

Dean of the Faculty of Economics and Management Ternopil Ivan Puluj National Technical University, Ternopil, Ukraine

Nataliia Marynenko

Professor of the Department of Economics and Finance Ternopil Ivan Puluj National Technical University Ternopil, Ukraine

\section{OUTSOURCING IT JAKO SPOSÓB NA POPRAWĘ EFEKTYWNOŚCI DZIAŁALNOŚCI GOSPODARCZEJ \\ IT OUTSOURCING AS A TOOL FOR IMPROVING THE EFFICIENCY OF BUSINESS OPERATIONS}

Dynamiczne globalizacyjni transformacji spowodowały przekształcenie rynku i środowiska Ukrainy i zwiększyły potrzebę zmiany nowoczesnej koncepcji zarządzania przedsiębiorstwem. Dziś pomyślna realizacja integracji europejskiej wektor rozwoju gospodarki narodowej wymaga od 
przedsiębiorstw zapewnienia elastyczności i elastyczności zarządzania, podejmowania decyzji, mających na celu zapewnienie ich konkurencyjności. Z kolei skuteczna realizacja strategicznych decyzji w warunkach dynamicznego rozwoju światowego i ukraińskiego rynków towarów i usług, rosnącej konkurencji i kryzysu spowodowały wykorzystanie outsourcingu jako skutecznego narzędzia doskonalenia systemu zarządzania przedsiębiorstwem, a przez to zwiększenie efektywności funkcjonowania przedsiębiorstwa jako całości.

Termin „outsourcing” pochodzi od angielskiego „outside source using”, „outside resourcing" - wykorzystania zasobów zewnętrznych. Pod pojęciem outsourcingu rozumie się zakontraktowane wykorzystanie zasobów materialnych, wartości i wiedzy osób trzecich z gwarantowanym poziomem jakości, elastyczności i wartości kryteriów kosztowych i ocenach za usługi wcześniej wykonywane wewnątrz firmy, z możliwością przejścia istniejącego personelu do usługodawcy $\mathrm{i} /$ lub przekształcenia procesu/upgrade i technologie wspierające biznes [1]. Wprowadzenie tego terminu do teorii zarządzania B. Anikin [2] i kilku innych naukowców wiążą z wykorzystaniem zasobów zewnętrznych organizacji lub providerów (dostawców) (z języka angielskiego to provide - „świadczenia usług”) w dziedzinie technologii informacyjnych. Outsourcing został upowszechniony $\mathrm{w}$ związku $\mathrm{z}$ rozwojem informacyjnych systemów i technologii. Początek „ery outsourcingu” odnosi się do lat 60-tych dwudziestego wieku, a mianowicie do 1962 roku, kiedy powstała firma Electronic Data System Corporation (EDS). Początki praktycznego outsourcingu jako metody współpracy produkcyjnej i zaawansowanymi technologiami zarządzania w przemyśle odnoszą się do okresu „wielkiej konfrontacji” pomiędzy dwoma dużymi mandżerami - Henry Forda i Alfreda Sloana-młodszego i ich gigantów branży motoryzacyjnej - kompanii Ford i General Motors. Termin „outsourcing” w celu zdefiniowania nowej koncepcji zarządzania został wprowadzony w 1989 roku, kiedy kompania Eastman Kodak zatrudniła outsiderów do nabywania, uruchamiania i utrzymywania własnych systemów przetwarzania informacji [3].

Literatura naukowa i biznesowa na zachodzie dostarcza zasadniczo różnych definicji outsourcingu. Podsumowując dotychczasowe poglądy naukowców na problemy outsourcingu celowe jest opisanie wizji istoty outsourcingu jako: przekazywanie funkcji pobocznych organizacjom zewnętrznym; metoda interakcji między podmiotami gospodarczymi; strategie zarządzania firmą [4].

Jednym z rodzajów outsourcingu jest outsourcing technologii informatycznych (outsourcing IT), który staje się coraz ważniejszy dla przedsiębiorstw informatycznych. Outsourcing IT to praktyka polegająca na przeniesieniu firmie outsourcerowej wszystkich lub części funkcji IT organizacji [5].

Outsourcing IT można również zdefiniować jako zróżnicowaną strategię biznesową obejmującą [6]: możliwość przeniesienia pracy innej niż podstawowa na dostawcę zewnętrznego, który posiada kompetencję, umiejętności i doświadczenie wystarczające, aby praca ta była skuteczniejsza niż dostawca wewnętrzny (to znaczy sama firma); nie tyle możliwość obniżenia kosztów, ile zapewnienie strategicznego skupienia się na wyniku [7]; możliwość uwolnienia pieniędzy i zainwestowania ich; szybki dostęp do technicznej i rynkowej wiedzy i doświadczenia branży, która stale się aktualizuje; możliwość rozwiązania problemu produkcyjnego poza firmą pozwalająca na zwiększenie współczynniku produktywności tej firmy; nie jest to jedyny sposób na przekształcenie biznesu, chociaż przy właściwym zarządzaniu obszarem działania może on działać jako katalizator zmian; zawsze jest inny wynik dla każdej firmy, pomimo pewnych wspólnych cech [8].

Outsourcing IT może pozwolić firmie na: szybkie ustanowienie nieprzerwanej pracy systemów informatycznych; określić wymaganą jakość usług; akumulować wysoko wykwalifikowanych specjalistów do rozwiązywania problemów; znacznie zmniejszyć ryzyko utraty ważnych danych; optymalizacja w bardziej przewidywalny sposób wytrat kosztów; skoncentrować zasoby firmy na specyfice jej działalności.

Główne zalety firm korzystających z outsourcingu IT to [6]: 1) możliwość koncentracji zasobów na głównej działalności; 2) zmniejszenie wydatków na obsługę informatyczną firmy; 3) 
minimalizowanie ryzyka poprzez przenoszenie infrastruktury IT na strony trzecie; 4) uzyskanie elastyczności finansowej.

Główne wady outsourcingu IT: 1) utrata pełnej kontroli nad pracą firmy obsługującej infrastrukturę IT; 2) zależność od zleceniodawcy, przede wszystkim w sprawach bezpieczeństwa; 3) spadek produktywności pracy własnego personelu z powodu utraty motywacji podczas zmian [9].

Właściwe wykorzystanie outsourcingu IT może odgrywają centralną rolę w procesach transformacji rynku organizacji, reformy aktywów, tworzenia $\mathrm{z}$ jest to skuteczny mechanizm szybkiego reagowania na przyszłe możliwości rozwoju firmy, inwestowania oszczędności w innowacje zamiast tworzenia zbędnej infrastruktury [10].

Outsourcing IT na Ukrainie ma swój numer przewagi nad konkurentami. Główne różnice między ukraińskimi programistami koncentrują się na wyniki podejścia ukraińskich programistów, głębokość ich udziału w projektach, a także ich mocne strony zaplecze matematyczne i techniczne $[11,375]$.

Więc, sukces podmiotów gospodarczych na rynku uwarunkowany jest ich zdolnością do dostosowywania się do szybko zmieniającego się otoczenia poprzez wprowadzanie innowacji, a jednym z ważniejszych sposobów na zwiększenie efektywności działalności gospodarczej jest outsourcing IT, co może pozwolić firmie na: szybkie ustanowienie nieprzerwanej pracy systemów informatycznych, określić wymaganą jakość usług, akumulować wysoko wykwalifikowanych specjalistów do rozwiązywania problemów, znacznie zmniejszyć ryzyko utraty ważnych danych, optymalizacja w bardziej przewidywalny sposób wytrat kosztów, skoncentrować zasoby firmy na specyfice jej działalności.

\section{Bibliografia}

1. Бравар, Жан-Луї, Морган, Роберт, 2007. Ефективний аутсорсинг: розуміння, планування та використання успішних аутсорсингових відносин: [пер. 3 англ.]. Дніпропетровськ: Баланс Бізнес Букс, 288 с.

2. Аникин, Б. А., Рудая, И. Л., 2007. Аутсорсинг и аутстаффинг: высокие технологии менеджмента: учеб. пособие. М.: Инфра-М, 288 с.

3. Анікін, Б. А., Руда, І. Л., 2009. Аутсорсинг і аутстаффінг. Високі технології менеджменту. ІНФРА-М, 320 с.

4. Микало, О.І., 2010. Підходи до визначення терміна “аутсорсинг”. Економічний вісник НТУУ “КПІ”, № 8, с. 111-115.

5. Н.П., Мешко, М.О., Єфремова, 2015. Розвиток ІТ-аутсорсингу в Україні. Вісник Дніпропетровського університету. Серія: Менеджмент інновацій, Випуск 5, с. 79-85.

6. Літошенко А. В., 2016. Проблеми визначення поняття IT-аутсорсингу та його особливості. Економічний аналіз: зб. наук. праць, Тернопільський національний економічний університет; редкол.: В. А. Дерій (голов. ред.) та ін., видавничо-поліграфічний центр Тернопільського національного економічного університету "Економічна думка", Том 23, № 2, c. 88-92.

7. Fabian, Dekker, Ferry, Koster, 2016. Outsourcing in 18 European countries: the role of worker power [Electronic resource]. - Retrived from: https://doi.org/10.1177/0143831X16633760

8. Leslie P., Willcocks, David, Feeny, 2006. IT outsourcing and core is capabilities: challenges and lessons at Dupont [Electronic resource]. - Retrived from: http://ismjournal.com/ITToday/outsource.pdf

9. Гребешкова О. М., Стельмах О. Ю., 2011. Становлення IT-аутсорсингу в Україні: огляд через призму світової практики. Формування ринкової економіки: зб. наук. пр., Вип. 25, c. $305-313$.

10. О. В. Осадчук, М. А., Йохна, 2010. Аутсорсинг як технологія підвищення ефективності діяльності сучасних організацій. Вісник Хмельницького національного університету, № 3, Т. 3, с. 119-122.

11. Тонюк М.О., 2017. Аутсорсинг як інструмент забезпечення ефективної діяльності підприємства. Економіка і суспільство, Випуск 10, с. 372-376. 
Анопріснко Тетяна

старший викладач кафедри планування території населених пунктів та будівництва, Харківський національний аграрний університет ім. В. В. Докучаєва,

м. Харків, Україна

Tetiana Anopriienko

senior lecturer of the department of planning of the territory of settlements and construction, V. V. Dokuchayev Kharkiv National Agrarian University, Kharkiv, Ukraine

\section{ОБ'ЄДНАНІ ТЕРИТОРІАЛЬНІ ГРОМАДИ - ШЛЯХ ДЛЯ ПОКРАЩЕННЯ ЕКОНОМІЧНОГО РОЗВИТКУ ДЕРЖАВИ UNIONED TERRITORIAL COMMUNITIES - WAYS TO IMPROVE ECONOMIC DEVELOPMENT OF THE STATE}

Одним із аспектів сучасних економічних перетворень в країні $є$ процес децентралізації влади. За словами Прем'єр-міністра України Володимира Гройсмана реалізація реформи децентралізації влади триває вже п'ять років і дала свої позитивні результати, та від якої очікується новий поштовх розвитку регіональної економіки та покращання життя людей у найближчому майбутньому [1].

Активно триває процес створення об'єднаних територіальних громад. Так, у 20152018 рр. створено 884 об'єднані територіальні громади на території 394 районів України, де мешкає 9,1 млн. осіб (25,7 \% від загальної чисельності населення України). Загальна площа об'єднаних територіальних громад становить 215,2 тис. кв. км $(38,5$ \% від загальної площі України, без урахування тимчасово окупованої території). У перспективних планах, затверджених Урядом, передбачається створення 1293 об'єднаних територіальних громад, які об'єднають 8906 територіальних громад[2]. Кількість громад які об'єднуються різна. Так, наприклад, на території Харківської області 77 територіальних громад об'єдналися у 17 об'єднаних територіальних громад загальною площею $5757,37 \mathrm{kм}^{2}$ та населенням 279244 осіб. При цьому Великобурлуцька селищна об'єднана територіальна громада, Малинівська селищна об'єднана територіальна громада, Малоданилівська селищна об'єднана територіальна громада, Мереф'янська міська об'єднана територіальна громада, Роганська селищна об'єднана територіальна громада та Циркунівська сільська об'єднана територіальна громада створені шляхом об'єднання 2 територіальних громад, а Золочівська селищна об'єднана територіальна громада $є$ найбільшою об'єднаною територіальною громадою області за кількістю рад - 13, але не за площею та населенням [3].

Зростає частка власних доходів загального фонду місцевих бюджетів у ВВП. Достатньо позитивна динаміка зростання спостерігається щодо надходжень від місцевих податків та зборів місцевих бюджетів, у тому числі від плати за землю. У 18324 областей об'єднані територіальні громади отримали земельні ділянки сільськогосподарського призначення із державної у комунальну власність у повному обсязі від запланованого. Так, 646 об'єднаних територіальних громад отримали у комунальну власність 1450,8 тис. га земель сільськогосподарського призначення [2]. Тому питання раціонального використання та територіального планування набуває все більшої актуальності.

Питання децентралізації влади та передачі земель сільськогосподарського призначення об'єднаним територіальним громадам було одним із пріоритетних напрямів роботи Державної служби України з питань геодезії, картографії та кадастру в 2018 році.

У 2019 році заплановано передати ще 141 об'єднаній територіальній громаді, які об’єдналися у 2018 році, землі сільськогосподарського призначення державної власності у комунальну власність, після проведення інвентаризації, уточнення даних та внесення відомостей до Державного земельного кадастру [4]. Зазначені заходи забезпечать 
ефективний контроль за використанням земель, та підвищать якісний склад та актуальність інформації, яка міститься у Державному земельному кадастрі України, і яка $є$ основою для розрахунку грошової оцінки земельних ділянок, та використання іï даних для визначення суми земельного податку, встановлення стартового розміру орендної плати за земельні ділянки, права на які виставляються на земельні торги.

\section{Перелік використаних джерел:}

1. Наступні роки реформи мають стати ривком розвитку регіональної економіки i покращення життя людей, - Володимир Гройсман : веб-сайт. URL:https:/decentralization.gov.ua/news/10246 (дата звернення: 01.03.2019).

2. Моніторинг процесу децентралізації влади та реформування місцевого самоврядування станом на 12 березня 2019: веб-сайт. URL: https://storage.decentralization.gov.ua/uploads/library/file/389/10.03.2019.pdf (дата звернення: 01.03.2019).

3. Об'єднані територіальні громади: перелік та основні дані : веб-сайт. URL: https://decentralization.gov.ua/gromada (дата звернення: 01.03.2019).

4. Публічний т звіт у Держгеокадастру за 2018: веб-сайт. URL: http://land.gov.ua/wpcontent/uploads/2019/03/Держгеокадастр_Публічний-звіт_2019.pdf (дата звернення: 01.03.2019).

УДК 332.025 .1

\section{Артеменко Людмила}

к. е. н., доцент

Тернопільський національний технічний університет імені Івана Пулюя,

Тернопіль, Україна

Ціх Галина

к. е. н., доцент

Тернопільський національний технічний університет імені Івана Пулюя

Тернопіль, Україна

Liudmyla Artemenko

PhD., Assoc., Prof.

Ternopil Ivan Puluj National Technical University

Ternopil, Ukraine

Halyna Tsikh

PhD., Assoc., Prof.

Ternopil Ivan Pul'uj National Technical University

Ternopil, Ukraine

\section{ПЕРСПЕКТИВИ РОЗВИТКУ РИНКУ \\ ОРГАНІЧНОЇ ПРОДУКЦІЇ УКРАЇНИ \\ DEVELOPMENT PROSPECTS FOR THE ORGANIC FOOD \\ MARKET IN UKRAINE}

Динамічним напрямом розвитку ресурсного світового потенціалу $\epsilon$ органічне виробництво, яке стало світовим модним трендом та позиціонується як взірцева модель сталого розвитку, що поєднує три його компоненти - економічну ефективність, екологічну спрямованість та соціальний аспект.

Органічні моделі країн Європейського Союзу включають низку інструментів для підтримки виробників господарства, які дотримуються базових вимог для захисту навколишнього середовища, а саме: бюджетне фінансування не підпадає під обмеження, фермери можуть отримувати дотації, субсидії держави протягом трьох років перехідного періоду, пільгове кредитування, консультаційну підтримку. Споживання органічної 
продукції на душу населення у Швейцарії найвище у світі - 274 євро на рік, успішно працює Дослідний інститут органічного сільського господарства FiBL [1]. Саме за допомогою спільного проекту із цим інститутом в 2007 р. було створено ТОВ «Органік стандарт» - перший вітчизняний орган сертифікації з надання послуг у сфері органічного виробництва.

Україна досягла вагомих результатів щодо розвитку власного органічного виробництва - ввійшла в двадцятку країн світу за площею органічних сільгоспугідь, у Європі стала потужним виробником органічної сировини та продукції. В нашій країні розміщено 75 \% європейських площ органічної гречки, 70 - проса, 28 - соняшника, 24 кукурудзи, 11 - ячменю, 9 \% - пшениці [2]. Виробники органічної продукції отримують додаткові конкурентні переваги: збільшення частки грошових коштів за рахунок економії на мінеральних добривах, засобах хімізації; вищий рівень доступності входження на експортні ринки сертифікованої органічної продукції; зростання чистих прибутків;розвиток сільських територій та забезпечення населення якісними продуктами харчування; формування конкурентного експортного потенціалу країни у цілому та передумов інвестиційно-інноваційних заходів екологічного розвитку регіону. Незважаючи на те, що в Україні виокремилась категорія споживачів, які створюють початкову нішу мотивованих до споживання безпечної, корисної їжі та прихильних до ведення здорового способу життя, на душу населення така продукція складає всього €3, що в першу чергу обумовлено низькою купівельною спроможністю населення.

Для того, щоб стати невід’ ємною складовою глобального ринку органічної продукції, необхідно організувати його відповідно до всіх міжнародних канонів. В цьому напрямку $є$ певні позитивні напрацювання. Створена система сертифікації органічної продукції за міжнародними стандартами, ухвалена стратегія розвитку аграрного сектору економіки на період до 2020 р., серед пріоритетних напрямів якої - забезпечення продовольчої безпеки, передбачена державна фінансова підтримка фермерським господарствам в якості безвідсоткових кредитів обсягом до 500 тис. грн. Деякі області почали закладати у місцеві бюджети фінансові кошти на часткову компенсацію вартості органічної сертифікації. У 2018 році був прийнятий Закон України «Про основні принципи та вимоги до органічного виробництва, обігу та маркування органічної продукції», який набере чинності із 2 серпня 2019 р., де передбачено, що державний логотип 3 написом «organic» означатиме вміст не менше ніж 95 \% органічних інгредієнтів, виробники будуть внесені до нового Державного реєстру операторів. Законом передбачено використання терміну «органічне виробництво», як сертифіковану діяльність щодо виробництва на всіх стадіях технологічного процесу (збирання, обробка, а також пов'язаних операцій щодо зміни стану продукції), де заборонено застосовувати пестициди, консерванти, штучні барвники, генетично модифіковані організми (ГМО). Продукція з етикетками «еко», «біо», «натуральний» буде усунена із продажу.

За даними Союзу виробників органічних сертифікованих продуктів «Органічна Україна» у 2017 році найбільшими виробниками в Україні були: TM «Organic Milk» (Житомирська область), яке спеціалізується на молочній продукції; ТМ «ЕтноПродукт» (Чернігівська область) - молочна, м’ясна продукція, зернові та бобові; ТМ «Старопорицьке» (Волинська область) - гречка, олійний льон та бобові; ТМ «Екород» (Київська область) крупи, борошно, соняшникова олія, мед та кавуни; «Галекс-Агро» (Житомирська область) тваринництво та зерно [3]. На жаль, у більшості цих господарств, продукція зорієнтована на експорт. Органічними сучасними здобутками можуть слугувати олієжировий завод в м. Диканька Полтавської області, виробництво органічних чаїв під торговою маркою MOL'FAR, завод «Бучацький екопродукт», що надає послуги по охолодженню молока та його транспортуванню, вирощування протеїнових добавок, батончиків з горіхами та медом.

Для формування дієвого механізму стимулювання виробництва та споживання органічної продукції в Україні доцільно комплексно застосовувати заходи, успішність яких доведена міжнародним досвідом, зокрема: 
створити сприятливі фіскальні та регуляторні умови 3 метою компенсації та підтримки сертифікації продукції, яка є досить витратною (не менше 15 тис. грн.);

запровадити державні замовлення органічної продукції з метою вирішення соціальних питань (харчування в навчально-освітніх закладах, лікарнях). Зокрема у Чехії, дошкільні, освітні та медичні заклади зобов'язані купувати 70\% органічних продуктів;

> створити умови для розбудови логістичної та транспортної інфраструктури ринку органічної продукції (доступність прямого збуту, формування фірмових магазинів, дилерських фірм, розвиток електронної торгівлі);

стимулювати внутрішній споживчий попит шляхом інформування населення про вплив споживання органічної продукції на здоров'я людей (проведення різних рекламних заходів і акцій, екскурсії на екогосподарства, виставки, дегустаційні ярмарки) та забезпечити ефективний захист прав споживачів від фальсифікованої продукції;

сприяти зростанню конкурентоспроможності органічних підприємств шляхом кардинальних змін технологічних процесів відповідно до міжнародних ветеринарних i фітосанітарних вимог.

В Україні державна підтримка розвитку органічного сільського господарства проходить процес формування, отже, доцільним є адаптація багаторічної практики провідних країн щодо побудови власної багатофункціональної агроекологічної моделі співробітництва між державою, приватними та громадськими організаціями органічного сектору. Такий напрям $є$ перспективним та пріоритетним для підприємств аграрного сектору, тому 3 методологічної точки зору, необхідно посилення ролі владних управлінських структур регіонального та місцевого рівнів щодо формування та регулювання органічного господарювання.

\section{Перелік використаних джерел:}

1. Органічна Україна у пошуках ефективної моделі [Електронний ресурс]. Режим доступу: http://infoindustria.com.ua/organichna-ukrayina-u-poshukah-efektivnoyi-modeli/

2. Логоша Р. В. Фактори розвитку ринку продукції органічного овочівництва а Україні. [Електронний ресурс]. - Режим доступу: file://C:/Users/Admin/Downloads/mnj_2018_11(2)_5.pdf

3. П'ять найбільших виробників органічної продукції в Україні [Електронний pecypc]. - Режим доступу: https://tokar.ua/read/24395 
ДВНЗ «Тернопільський коледж харчових технологій і торгівлі», Тернопіль, Україна

Науковий керівник: Обуд Оксана Петрівна

викладач-методист

ДВНЗ «Тернопільський коледж харчовихтехнологій і торгівлі» аспірант кафедри маркетингу ТНЕУ

Bodnar Diana

3-PTB-134/9

Ternopil College of Food Technologies and Trade Ternopil, Ukraine

Scientific supervisor: Oksana Obud

Teacher-Methodist of the State Higher Educational Institution Ternopil, Ukraine College of Food Technologies and Trade, post - graduate student of the Department

\section{ДІЯЛЬНІСТЬ ПІДПРИЕМСТВ В УМОВАХ КОНКУРЕНЦІї ACTIVITY OF ENTERPRISES IN CONTRACTING CONDITIONS}

Формування в Україні конкурентних відносин торговельних підприємств висуває до сучасних суб'єктів ринку вимогу належно реагувати на дію об'єктивного ринкового явища конкуренції, й забезпечувати конкурентоспроможність таких підприємств. Сьогодні актуальним $є$ питання системного підходу під час підвищення конкурентоспроможності підприємства, тобто ведення послідовної, конкурентної боротьби за сегмент ринку збуту.

Для успішного конкурування як на внутрішньому, так і на зовнішньому ринку, необхідно мати детальну і достовірну інформацію про наявне конкурентне середовище, яке виявляється через сукупність окремих складових і перш за все - конкурентоспроможність.

Як економічну категорію конкурентоспроможність варто розглядати на рівні конкурентоспроможності продукції, тобто самого товару чи послуг, конкурентоспроможності підприємства, галузі та конкурентоспроможності економіки держави. Між усіма цими рівнями є досить тісний як внутрішній, так і зовнішній зв'язок.

У широкому розумінні сама конкурентоспроможність - це обумовлена конкретними економічними, соціальними та політичними факторами відповідна позиція держави в цілому та конкретного товаровиробника зокрема, як на внутрішньому, так і на зовнішньому ринку [1]. Саме сукупність таких дій щодо впливу окремих факторів формує як внутрішнє, так i зовнішне конкурентне середовище. В умовах відкритої економіки така дія може виявлятися у спроможності держави чи галузі або окремого підприємства протистояти міжнародній конкуренції на власному ринку чи на ринках інших держав. Для кожного окремого рівня $\epsilon$ своє середовище і своя конкурентоспроможність.

Нині дослідження конкуренції проводиться за двома основними напрямами: виявлення основних факторів, що визначають конкурентоспроможність підприємства на ринку, i ступінь застосування інструментів маркетингових досліджень. Конкурентоспроможність підприємства становить самостійну системну категорію, яка відображає ступінь реалізації мети підприємства в його взаємодії 3 навколишнім середовищем [2]. Якщо проаналізувати складові конкурентоспроможності, то можна визначити фактори, що впливають на неї. Серед усіх факторів конкурентоздатності товару $\epsilon$ визначальні, тобто ключові, які забезпечують успіх на ринку. Формування ключових факторів успіху товару відбувається під впливом багатьох чинників: одні з них виникають у середовищі ділових кіл, науково-дослідних лабораторій, інші ініціюються різними товариствами, засобами масової інформації. 
За економічними умовами споживання конкурентоздатність включає такі показники, як енергоємність, економічність у споживанні сировини на одиницю продукції, що випускається, або здійснюваної роботи; вартість сировини та експлуатаційних матеріалів, безвідходної технології, надійність, періодичність і вартість ремонтів, вартість запасних частин; чисельність обслуговуючого персоналу, його кваліфікація, рівень заробітної плати.

Знаючи ступінь конкурентоспроможності, взаємозв'язок між часткою задоволення потреб та обсягом продажу на майбутнє, оцінюють суму прибутку, яка була запланована. Однак будь-який товар завжди з часом втрачає конкурентоздатність.

Сьогодні сучасна ринкова економіка України формується та розвивається одночасно iз загостренням конкурентної боротьби у всьому світі, яка при цьому 3 кожним роком набуває більш глобальних масштабів. Проблема формування висококонкурентної національної економіки є на сьогодні ключовою, а реалії свідчать, що більшість вітчизняних суб'єктів господарювання $€$ неконкурентоспроможними на світових ринках, що підтверджується результатами рейтингів провідних міжнародних організацій, згідно з якими Україна посідає одне із останніх місць серед досліджуваних країн [3]. За таких умов можливості стабільного економічного зростання як в цілому економіки України, так й окремого товаровиробника багато в чому залежать від ефективного вирішення питання, пов'язаного 3 побудовою відповідної системи управління підприємством, зокрема управління його конкурентоспроможністю в першу чергу. Саме тому перед керівництвом постає завдання пошуку стратегічних можливостей та формування нових стійких конкурентних переваг, які в подальшому дозволять виявляти та реалізовувати невикористані резерви конкурентоспроможності підприємства. I саме тому дослідження та пошук шляхів розвитку конкурентоспроможності підприємств на шляху трансформаційних ринкових перетворень $є$ досить актуальним завданням, яке потребує нагального вирішення.

\section{Перелік використаних джерел:}

1. Посвятенко Т. І. Оцінювання та аналіз конкурентоспроможності підприємства // Держава та регіони. Серія: Економіка та підприємництво. - 2004. - №6. - 215 с.

2. Масленикова Н. П. Управление развитием организации. - М.: Центр экономики и маркетинга, 2002. - 304 с.

3. Кирчата I. М. Оцінка конкурентного потенціалу в системі управління конкурентоспроможністю підприємства: дис. кандидата екон. наук: 08.00.04 / Кирчата Ірина Миколаївна. Х., 2007. - 214 с. 
Ігнатенко Микола доктор економічних наук, доцент, завідувач кафедри економіки ДВНЗ «Переяслав-Хмельницький ДПУ імені Григорія Сковороди» м. Переяслав-Хмельницький, Україна

Кучеренко Микола старший викладач кафедри обліку та оподаткування ДВНЗ «Переяслав-Хмельницький ДПУ імені Григорія Сковороди» м. Переяслав-Хмельницький, Україна

Mykola Ihnatenko

Doctor of Economics, Associate Professor, Head of the Department of Economics Pereiaslav-Khmelnytskyi Hryhorii Skovoroda State Pedagogical University Pereiaslav-Khmelnytskyi, Ukraine Kucherenko Mykola Senior lecturer of the Department of Accounting and Taxation Pereiaslav-Khmelnytskyi Hryhorii Skovoroda State Pedagogical University Pereiaslav-Khmelnytskyi, Ukraine

\section{УДОСКОНАЛЕННЯ КОНКУРЕНТОСПРОМОЖНОСТІ АГРАРНИХ ПІДПРИЕМСТВ THE IMPROVEMENT OF AGRICULTURAL ENTERPRISES COMPETITIVENESS}

Проблема забезпечення й постійного підвищення конкурентоспроможності товаровиробників не втрачає своєї актуальності. Ї̈̈ розв'язання напряму залежить від спроможності сільськогосподарських галузей та підприємств зберегти життєздатність у довгостроковій перспективі, підтримувати безперервність свого розвитку й завойовувати бажану частку ринку. Жорстка конкуренція на всіх ринках, ускладнена в нашій країні наявністю загальної економічної кризи, зумовлює необхідність розробки заходів, спрямованих на створення й реалізацію конкурентних переваг.

Однак забезпечення й підтримання конкурентних переваг 3 кожним днем ускладнюється внаслідок виснаження й зменшення продуктивності природних ресурсів, обмеженості інформації, настання ризикових ситуацій, невизначеності та ін. Висока мінливість навколишнього середовища й посилення впливу невизначеності часто роблять конкурентні переваги нетривалими, унікальність ресурсів і можливостей - ненадійними, а ефективні сьогодні підходи можуть уже завтра застаріти. У таких умовах розробка адаптаційних заходів щодо створення стратегічних конкурентних переваг на базі використання власного стратегічного потенціалу набуває особливої значущості, адже практично всі управлінські рішення так чи інакше торкаються потенціалу підприємств агросфери, його використання, прирощення його розміру, управління ним. Без цього неможливо забезпечити конкурентоспроможність, інноваційність і сталий розвиток.

Основною умовою конкурентного розвитку підприємств агропродовольчої сфери $€$ формування достатніх фінансово-кредитних ресурсів. Без зростання інвестицій та підвищення ефективності їх використання неможливі інноваційні процеси як пріоритетні для економічного піднесення. Тільки конкурентоспроможне виробництво достатньою мірою забезпечує власне розширене відтворення та надходження до бюджету. Тому важливе значення у стратегіях конкурентоспроможності має розвиток фондового ринку, логістичного забезпечення діяльності з метою зменшення втрат на стадії реалізації продукції та послуг.

Наступним напрямом залучення інвестицій для підвищення конкурентоспроможності підприємств агропродовольчої сфери, є лізинг. Предметом лізингу можуть бути будівлі, споруди, машини, обладнання, інвентар, транспортні засоби, земельні ділянки і будь-які інші 
засоби виробництва. Законодавчими актами можуть бути встановлені обмеження на використання в якості предмета лізингу їх окремих категорій і земельних ділянок.

Складовими частинами стратегії підвищення конкурентоспроможності $\epsilon$ організаційна та управлінська культура суб'єктів господарювання, їх імідж у споживачів (якість, дизайн, популярність торгової марки, сервіс, система знижок, ціна, фірмовий стиль), бізнес-імідж (ділова репутація, добросовісність, надійність, лояльність до партнерів, інформаційна відкритість, ділова активність), соціальний імідж (спонсорство, меценатство, участь у рішенні проблем екології, зайнятості, охорони здоров'я, сприяння конкретним особам), імідж галузей для державних структур (значимість продукції для країни, участь у соціальних програмах, надання робочих місць).

Доведено, що у сучасних умовах виникає необхідність у зміні орієнтації і критеріїв оцінки продукції, що виробляється підприємствами, які належать до галузей агропродовольчої сфери. Конкурентоспроможність будь-якого товару може бути визначена тільки в результаті порівняння, і тому є відносним показником.

Особливе місце у вивченні ринку займає довгострокове прогнозування його розвитку. На основі вивчення ринку і вимог покупців вибирається продукція, по якій буде проводитися аналіз чи формуються вимоги до майбутнього виробу, а далі визначається номенклатура параметрів. При аналізі повинні використовуватися ті ж критерії, якими оперує споживач, вибираючи товар. По кожній з груп параметрів проводиться порівняння, що показує наскільки ці параметри близькі до відповідного параметру потреби.

Аналіз конкурентоспроможності починається з оцінки нормативних параметрів. Якщо хоча б один з них не відповідає рівню, який наказаний нормами і стандартами, то подальша оцінка конкурентоспроможності продукції недоцільна, незалежно від результату порівняння по інших параметрах. У той же час, перевищення норм і стандартів і законодавства не може розглядатися як перевага продукції, оскільки 3 погляду споживача воно часто $є$ марним $\mathrm{i}$ споживчої вартості не збільшує. Винятки можуть становити випадки, коли покупець зацікавлений у деякому перевищенні діючих норм і стандартів у розрахунку на жорсткість їх у майбутньому.

Результати оцінки конкурентоспроможності використовуються для вироблення висновку про неї, а також - для вибору шляхів оптимального підвищення конкурентоспроможності продукції для вирішення ринкових завдань. Однак факт високої конкурентоспроможності самого виробу є лише необхідною умовою реалізації цього виробу на ринку в заданих обсягах. Слід також враховувати форми і методи технічного обслуговування, наявність реклами, торгово-політичні відносини між країнами тощо.

У результаті оцінки конкурентоспроможності продукції можуть бути прийняті наступні шляхи підвищення конкурентоспроможності: зміна складу, структури застосовуваних матеріалів (сировини, напівфабрикатів), комплектуючих виробів чи конструкції продукції; зміна порядку проектування продукції; зміна технології виготовлення продукції, методів випробувань, системи контролю якості виготовлення, зберігання, пакування, транспортування, монтажу; зміна цін на продукцію, цін на послуги, по обслуговуванню і ремонту, цін на запасні частини; зміна порядку реалізації продукції на ринку; зміна структури і розміру інвестицій у розробку, виробництво і збут продукції; зміна структури та обсягів коопераційних поставок при виробництві продукції та цін на комплектуючі вироби і складу обраних постачальників; зміна системи стимулювання постачальників; зміна структури імпорту і видів імпортованої продукції.

Конкурентоспроможність являє собою характеристику товару, що відображає його відмінність від товару конкурента за ступенем задоволення конкурентної суспільної потреби. Конкурентоспроможність визначається сукупністю властивостей цієї продукції, які входять до складу іiі якості і важливих для споживача. Саме вони визначають витрати споживача по придбанню, споживанню (експлуатації) та утилізації продукції.

Оцінка конкурентоспроможності товарів (послуг) підприємств, що належать до галузей агропродовольчої сфери, починається з визначення мети дослідження. Якщо 
необхідно визначити положення даного товару в ряді аналогічних, то досить провести їх пряме порівняння по найважливіших параметрах. Якщо метою дослідження $є$ оцінка перспектив збуту товару на конкретному аграрному ринку, то в аналізі повинна використовуватися інформація, яка включає відомості про продовольчі вироби, які вийдуть на ринок у перспективі, а також відомості про зміну діючих у країні стандартів $\mathrm{i}$ законодавства, динаміки споживчого попиту.

УДК 330.3

\section{Катрусяк Христина}

студентка групи ПП-42

Тернопільський національний технічний університет імені I. Пулюя

м.Тернопіль, Україна

Бажанова Наталія

к.е.н., доцент кафедри економіки та фінансів

Тернопільський національний технічний університет імені I. Пулюя

м.Тернопіль, Україна

Khrystyna Katrusiak

Student of the group ПП-42

Ternopil Ivan Puluj National Technical University

Ternopil, Ukraine

Natalia Bazhanova

Ph.D. (Economics), Associate Professor,

Department of Economics and Finance

Ternopil Ivan Puluj National Technical University

Ternopil, Ukraine

\section{ПРОБЛЕМИ ВПРОВАДЖЕННЯ ІННОВАЦІЙНИХ ТЕХНОЛОГІЙ ВИРОБНИЦТВА В УКРАЇНI \\ PROBLEMS OF INNOVATIVE PRODUCTION TECHNOLOGIES IMPLEMENTATION IN UKRAINE}

Актуальність. В економіці розвинутих країн важливу роль беруть участь інноваційні процеси, тобто використання нових знань та технологій у виробництві. У сучасному світі інноваційний розвиток дає можливість для побудови міцної економіки. Для українських підприємств впровадження інновацій є важливим поштовхом для економічного розвитку як всередині країни, так і на міжнародному рівні. На жаль в Україні, процесам створення та регулювання сприятливих умов щодо розвитку політики експорту вітчизняної інноваційної продукції приділяється не достатньо уваги.

Аналіз останніх досліджень і публікацій. Дослідженням проблем щодо впровадження інноваційних технологій виробництва займаються вітчизняні та іноземні відомі учені: Ю. Бажала, В. Беренса, В. Власової, В.М. Гейця, О.А. Лапка, В.І. Терехова, А. Соляник, Л. Дубровіної, І. Юдіна, А. Савчука, С. Шмідта. Проте чимало питань щодо механізму розвитку інноваційної діяльності й досі залишаються невисвітленими та потребують детального дослідження.

Виклад основного матеріалу. В Україні інноваційна структура поки розвинута не належним чином. Причиною цьому є низький рівень використання наукових досліджень, незначним є зростання створення інновацій. На сьогодні, Україна входить до вісімки країн, які мають необхідний потенціал для сучасного виробництва в авіаціній сфері, а вітчизняна продукція машинобудування займає одне з провідних місць в Європі, проте, у всьому 
іншому значно відстає. На це впливає дуже багато чинників, зокрема, нестабільна політична та економічна ситуація в державі.

У сучасних умовах підприємствам надзвичайно важко утримувати свої позиції на ринку, що у свою чергу не дає змоги вкладати кошти у розвиток інновацій, оскільки керівники компаній ледь намагаються заощадити власні кошти.

Перехід економіки України до впровадження новітніх інноваційних процесів вимагає просування нововведень в усіх іiі секторах. Для цього необхідно створити певні умови, які дозволять розробляти ідеї прикладного значення. Роль держави полягає у тому, щоб покращити інвестиційний клімат, створити зони інноваційного підприємництва, сприяти експорту високотехнологічної продукції, розвивати міжнародні зв'язки та обмінюватись, а також запозичувати інформацію щодо використання нових знань та технологій, зменшення податкового тиску для інноваційних підприємств на початковій стадії розвитку, усунення суперечностей положень законодавчих і нормативних актів.

Висновки. Отже, підсумовуючи усе вищесказане можна зробити висновок, що в сучасному світі, інноваційні процеси значним чином впливають на розвиток економіки, а міцна економіка сприяє швидкому й ефективному впровадженню інновацій. Недоліком 3 боку державного сектора в Україні, є те, що скорочення витрат не дозволяє в повному обсязі розвиватися інноваціям та негативно позначається на розвитку українських підприємств в цілому. Проте цю ситуацію можна змінити впроваджуючи новий підхід та сучасні принципи щодо інноваційної політики з боку держави, що у свою чергу, дозволить підприємствам ефективно створювати такі інновації, які будуть сприяти розвитку міцної економіки в Україні.

\section{Перелік використаних джерел:}

1. Ганечко I. Проблеми розвитку інновацій в Україні, К., 2011. 21-24c.

2. Матюшенко I. Проблеми інноваційного розвитку України на сучасному етапі // Економіка. - 2002.-№3.

3. Пенькова О Г. Проблеми реалізації інноваційної стратегії розвитку України К., 2007. $96-99 c$.

4. Павлюк М. В. Мотиваційні можливості вітчизняного законодавства у сфері інноваційної діяльності // М. В. Павлюк // Вісник Хмельницького національного університету. - 2010. - № 1. - с. 117 - 121. 
Красноруцький Олексій

доктор економічних наук, професор

завідувач кафедрою організації виробництва, бізнесу та менеджменту

Зайцев Юрій

доктор економічних наук, доцент

Харківський національний технічний університет сільського господарства

імені Петра Василенка

Oleksiy Krasnorutskyy

Doctor of Economics, Professor

Head of Production, Business and Management Department

Yurii Zaitsev

Doctor of Economics, Associate Professor

\section{НАПРЯМКИ ВДОСКОНАЛЕННЯ ЗБУТОВОЇ ДІЯЛЬНОСТІ АГРАРНИХ ПІДПРИЕМСТВ DIRECTIONS FOR IMPROVEMENT OF SELLING AGRICULTURAL ENTERPRISES}

Продукція сільського господарства в Україні виробляється господарствами населення та підприємствами різних організаційно-правових форм. До малих сільськогосподарських виробників можна віднести фермерські господарства та господарства населення. Особливу увагу варто приділити саме останнім, так як ї питома вага в загальному обсязі продукції аграрного сектору, незважаючи на іï відчутне скорочення: 3 61,6\% у 2000 р. до 43,6\% у 2017 р., залишається досить високою, перевищуючи в питомій вазі продукції тваринництва, яке становить 54,2 \%, долю сільськогосподарських підприємств та фермерських господарств. Однією з проблем з організація збуту продукції цих виробників.

Проблемам забезпечення ефективної діяльності аграрних товаровиробників, питанням збуту продукції, функціонування ринку аграрної продукції, гармонізації відносин учасників ринкових процесів присвячені дослідження багатьох вітчизняних та зарубіжних вченихекономістів, зокрема, В. М. Алексійчука, О. М. Алімова, В. Я. Амбросова, О. А. Бугуцького, В. В. Булюка, С. В. Васильчак, А. І. Даниленка, Дж. Донеллі, П. С. Зав’ялова, А. А. Мазаракі, П. М. Макаренка, Л.О. Мармуль, Б.Й. Пасхавера, .М. Підлісецького, Дж. П. Пітера, О. В. Пустовойта, П. Т. Саблука, А. С. Савощенка, В. І. Топіхи, В. М. Трегобчука, та інших.

Складність взаємовідносин аграрних підприємств з суб'єктами ресурсних ринків поряд 3 об'єктивно довготривалими циклами виробництва більшості видів аграрної продукції на фоні несприятливості політики фінансово-кредитних інституцій та нерозвиненості ринкової інфраструктури й методів забезпечення руху товарів призводить до ситуації, коли раціонально організований збут продукції підприємства $\epsilon$ не тільки завершальною стадією виробничо-комерційного циклу, на якій формуються його результати, а й визначальним важелем формування економічної ефективності всієї діяльності. Таким чином, досягнення певного рівня організації збутової діяльності аграрного підприємства та раціоналізація управління збутом $\epsilon$ основою забезпечення розширеного відтворення та стабілізації розвитку суб'єкта економічних відносин.

Об’єктивним критерієм трансформації характеристик функціонування систем розподілу аграрної продукції на ринку є, передусім, зміни в структурі розподілу продукції через різні канали реалізації. Зважаючи на те, що продаж продукції переробним підприємствам, населенню та на ринку є окремими випадками прояву прямого збуту або побудови товаровиробниками вертикальних маркетингових систем, критичними в даному контексті $\epsilon$ зміни питомої ваги обсягів аграрної продукції, що реалізуються через посередницькі мережі, тобто комерційні ланцюги маркетингових посередників. 
Головною тенденцією трансформації систем збуту продукції аграрних підприємств $є$ зміна їх орієнтації з застосування схем прямого збуту на використання інфраструктурних елементів обслуговування сфери обігу продукції. Дана тенденція притаманна всім без винятку видам продукції та, відповідно, об'єктовим ринкам, а найбільш суттєві зрушення відбулися в товарних сегментах зернових та олійних культур, картоплі, а також м'яса худоби та птиці. Крім того, місце торговельним посередникам знайшлося навіть на ринках таких видів аграрної сировини, як цукрові буряки та молоко, що, в цілому, є нетиповим для будьякої господарської системи через технологічні характеристики даних видів аграрної сировини.

Все різноманіття типології, класифікації та генерування маркетингово-збутових стратегій, яке накопичене протягом розвитку світової економічної науки, за критерієм впливу на економічну ефективність діяльності вітчизняного аграрного підприємства та розвиток його економічного потенціалу варто поєднати у три основні типи стратегій, а саме: стратегію розширення, стратегію стабілізації та стратегію виживання. В сучасних умовах вітчизняне сільськогосподарське підприємство здатне та повинне управляти обсягами виробництва та реалізації продукції, регулюючи пропорції залучення економічних ресурсів. При цьому кожен 3 визначених типів стратегії має обиратися 3 урахуванням виробничокомерційних можливостей підприємства та конкретної ситуації на ринку, а дотримання принципу гнучкості має забезпечуватися адаптивністю системи збуту продукції.

Доцільним є формування агроконсалтингових служб на регіональному рівні, як відповіді на виклики конкурентної ситуації на цільових ринках. 3 використанням послуг такої служби сільськогосподарські підприємства найповніше зможуть реалізовувати свій виробничо-комерційний потенціал та отримувати еквівалентні завданням виробництва продукції та стабілізації розвитку результати своєї діяльності. При цьому створення регіональних агроконсалтингових служб з широким обсягом функціонального навантаження та комерційних повноважень в декількох регіонах рано чи пізно призведе до появи господарських зв'язків між ними на засадах співробітництва. Останнє дасть змогу створити альтернативний вітчизняній біржовій торгівлі, яка неналежним чином зарекомендувала себе протягом останніх років свого функціонування, елемент інфраструктури внутрішнього ринку аграрної продукції. Останнє сприятиме гармонізації економічних інтересів учасників ринку аграрної продукції та створюватиме умови для розширеного відтворення їх капіталу.

Безпосередньо для малих підприємств одним із перспективних напрямів $є$ розвиток кооперативного руху. Одним з прикладів є Перший національний аграрний кооператив [1], який функціонує в у Хмельницькій області. Основними принципами його роботи є: бережливе ставлення до землі, співпраця, професіоналізм та постійний розвиток, повага один до одного, чесність та відкритість. основним напрямом $є$ гарантована реалізація сільськогосподарської продукції, поряд з якої кооператив пропонує такі: збір продуктів за вказаними характеристиками і гарантована реалізація їх на вигідних умовах, пільгове придбання засобів господарювання, юридичний супровід членів кооперативу, турбота про громаду і безперервна освіта. Як бачимо зародження цього руху як оптимізація збутової діяльності фактично переросло у соціально-економічне явище, яке сприяє розвитку сільської місцевості в цілому та зростанню обсягів виробництва аграрного сектору.

\section{Перелік використаних джерел:}

1. Перший національний аграрний кооператив. Офіційний веб-сайт. URL: http://www.pnak.com.ua/

2. Красноруцький О. О. Оптимізація формування та використання економічного потенціалу в сільськогосподарських підприємствах: [монографія] / [кол. авторів; за ред. О. О. Красноруцького]. - Одеса: ТОВ «Лерадрук», 2013. - 211 с. 
Крупка Андрій

к.е.н., старший викладач

Тернопільський національний технічний університет імені Івана Пулюя

Пиріг Галина

доцент, Тернопільський національний економічний університет

Andrii Krupka

Ph.D, Ternopil Ivan Puluj National Technical University

Halina Pyrig

Ph.D, Ternopil National Economic University

\section{КУЛЬТУРНО-МИСТЕЦЬКІ ІНДУСТРІЇ В УКРАЇНІ: СУЧАСНИЙ СТАН ТА ПЕРСПЕКТИВИ РОЗВИТКУ \\ CULTURAL AND ARTISTIC INDUSTRY IN UKRAINE: CURRENT STATE AND DEVELOPMENT PROSPECTS}

Культурно-мистецькі індустрії та креативне підприємництво - це відносно нові поняття в українському контексті. ЮНЕСКО визначає креативні індустрії як індустрії, метою яких $є$ «створення, виробництво і комерціалізація творчих (креативних) змістів, які $\epsilon$ нематеріальними і культурними за своєю природою. Такі змісти зазвичай захищені правом інтелектуальної власності і вони можуть набрати форми продукту чи послуги» [1].

Окремі науковці стверджують, що це «діяльність, в основі якої лежить індивідуальне творче начало, навик чи талант, і яка може створювати додану вартість і робочі місця шляхом створення та експлуатації інтелектуальної власності». Залежно від контексту, культурно-мистецькі індустрії також можуть називатися креативними індустріями, або на економічному слензі «галузями майбутнього» [2].

Основними характеристиками і сучасними трендами креативних індустрій, на нашу думку, є такі:

- індикатори руху від інформаційної до концептуальної епохи, де головною цінністю будуть ідеї (концепти): все менше людей будуть працювати на роботодавців, і все більше - на себе самих;

- с стирают межі між наукою і мистецтвом, креативністю та інноваціями, між країнами;

- $\quad$ культура та креативність, ввічливість та інтелект, атмосферність і людська доброта - це ті ресурси, якими живляться креативні індустрії;

- $\quad$ швидкий вільний доступ до Інтернету для забезпечення обміну і доступу до величезних інформаційних потоків;

- опора на малий, а не на великий бізнес;

- органічна культурна та етнічна різноманітність, яка дозволяє створювати нові унікальні ідеї та бачення світу.

Безумовно, в Україні уже давно назріла потреба системної підтримки творчих індустрій, адже в теперішньому комерціалізованому світі культура поступово стає товаром. Проте, розвиток культурно-мистецьких індустрій характеризується низкою специфічних проблем, серед яких доцільно виокремити:

- «молодість» ринків. Ринки будуються на основі запозичення або адаптації зарубіжних моделей, зразків і часто - культурно-мистецьких продуктів. Наслідком «молодості» ринків є примітивне уявлення замовника про творче виробництво, що позначається на його очікуваннях і рівні оплати творчої праці;

- перевага імпорту. Величезна кількість культурно-мистецьких галузей сьогодні в Україні купує творчу продукцію на зарубіжних ринках. Частково - це наслідок нерозвиненості ринків культурно-мистецьких індустрій (ще з радянських часів «імпортне» $\mathrm{i}$ 
«якісне» були для вітчизняного споживача синонімами). А імпорт, звичайно ж, дешевший, ніж інвестиції в розвиток внутрішнього «творчого» ринку, його інфраструктуру, професійну освіту, просування продукції; однак, саме там, на наш погляд, формується система, що створює якісний творчий продукт. У всьому світі ці умови для розвитку ринку забезпечуються на державному рівні і зовсім необов'язково через механізми прямого фінансування. Ефективними у цьому контексті можуть бути податкові пільги, спрощені бюрократичні процедури тощо;

- протиріччя між культурою і комерцією, яке часто проявляється у формі конфліктних ситуацій (державні установи культури часто не готові до конкуренції на ринку, а недержавні виробники перебувають поза полем дії офіційної культурної політики);

- нерозвинена професійна освіта і дефіцит кадрів;

- слабкість мережевих структур у багатьох секторах, відсутність професійного співтовариства, корпоративної етики, «внутрішньоцехових» правил і стандартів діяльності.

Необхідно зазначити, що інвестиції у створення якісного вітчизняного творчого продукту, як правило, знаходяться за межами сфери інтересів зарубіжних інвесторів. Це прерогатива держави або приватна ініціатива вітчизняних бізнесменів. У сучасному світі стає вигідно готувати своїх програмістів, акторів, дизайнерів, тобто розвивати власний креативний потенціал. Але щоб зробити його конкурентоспроможним і привабливим для інвесторів, потрібні стартові вкладення з боку держави, необхідні стимули для розвитку i, насамперед, фінансові та податкові. Зарубіжним компаніям цікаво інвестувати у вже наявні ресурси, а не в творчий потенціал. I якщо такого потенціалу не створювати, доведеться залишитися країною-експортером сировини.

Розвиток культурно-мистецьких індустрій має стати важливим пріоритетом сучасної фінансової політики держави у галузі культури і мистецтва. Визнання провідної ролі творчого сектора i творчого класу демонструє політичну волю рухатися в бік постіндустріального розвитку (на противагу концепції «енергетичної держави», чию могутність побудовано на експорті природних ресурсів). Сьогодні низка розвинених країн світу вже прийняла таке рішення (у цьому контексті доцільно згадати програми Creative State в Австралії або стратегію «Творча Британія» [3]). Крім загального політичного спрямування, необхідною $є$ низка більш конкретних, але дуже вагомих рішень (створення системи пільгового оподаткування, спрощення бюрократичних процедур, розширення можливостей доступу до фінансових ресурсів для креативних бізнесів тощо).

Окремо слід сказати про впровадження сучасних форм статистичної звітності та ведення статистичного обліку у сфері культурно-мистецьких індустрій, що дозволить проводити міжнародні зіставлення даних.

Очевидно, що розвиток культурно-мистецьких індустрій в Україні буде гальмуватися до тих пір, поки не будуть створені сприятливі умови для розвитку малого і середнього бізнесу загалом. Можливість розпочати і вести свій бізнес-проект - ключова і необхідна умова зростання творчої економіки. Важливим у зазначеному контексті є створення бізнесінкубаторів для «культурних» підприємців, яких в Україні практично немає.

Відтак вважаємо, що надзвичайно актуальними сьогодні є порівняльні дослідження програм підтримки культурно-мистецьких індустрій в різних країнах світу для вироблення політичних і законодавчих ініціатив та запрошення зарубіжних фахівців для впровадження кращих освітніх практик в Україні. Дослідження в регіонах свідчать, що в українських містах $\epsilon$ дефіцит культурних ініціатив. У цьому контексті доречно згадати досвід Китаю, де відсутність власних культурних компаній вирішили замістити запрошенням зарубіжних підприємців. Це не просто «заповнило порожнечу», а й дало можливість місцевим підприємцям познайомитися 3 новими практиками роботи, якісно оновити свою діяльність. Слід зазначити, що успішні міжнародні проекти будуються на трьох принципах: освітні ініціативи, спільні проекти «культурних» людей з різних країн і міжнародні дослідження. 
Отже, за умови грамотного державного протекціонізму культурно-мистецькі індустрії в Україні можуть стати джерелом наповнення бюджету, поштовхом для розвитку малого $\mathrm{i}$ середнього бізнесу та дієвим каналом промоції культури і мистецтва в сучасних умовах.

\section{Перелік використаних джерел:}

1. Культура и устойчивое развитие // ООН по вопросам оброзования, науки и культуры. - 2015. [Електронний ресурс] - Режим доступу: http://ru.unesco.org/.

2. Антошкіна Л.І. Креативний розвиток України / Л. І. Антошкіна. [Електронний pecypc] - Режим доступу: http://ir.kneu.edu. ua:8080/bitstream/2010/1783/1/Antoshkina.pdf.

3. Facing the Challenges of the Creative Economy // Creative Economy, Cultural Policy. 2016. [Електронний ресурс] - Режим доступу: http://creativeclusters.com/.

УДК 332.133

Лазарюк Валерій доцент кафедри технології та обладнання зварювального виробництва Тернопільський національний технічний університет імені Івана Пулюя,

м. Тернопіль, Україна

Valeriy Lazaryuk

Associate Professor of the Department of Welding Technology and Equipment Ternopil Ivan Puluj National Technical University

Ternopil, Ukraine

\section{ІННОВАЦІЙНІ ЛАБОРАТОРІЇ ФАБЛАБ ЯК ІНДИКАТОР РЕГІОНАЛЬНОГО РОЗВИТКУ КРЕАТИВНОЇ ЕКОНОМІКИ NNOVATION FABRICATION LABORATORIES FABLAB AS REGIONAL DEVELOPMENT INDICATOR OF CREATIVE ECONOMY}

Домінуючим типом виробництва у постіндустріальному суспільстві вважають креативні підприємства 3 індивідуальним способом виробництва. Великі підприємства, що працюють за рахунок масштабу, поступово замінюються високотехнологічними малими підприємствами, що використовують цифрові технології виробництва. При цьому відбувається заміна матеріальної складової виробництва на інтелектуальні інформаційні ресурси, що дозволяє зменшити виробничі затрати. Одним із можливих сценаріїв розвитку України вважають постіндустріальний стрибок, коли за рахунок інтенсивного міжнародного інформаційного обміну відбувається швидке освоєння інвестицій та технологій.

Через стрімкий розвиток інтернету речей, інтернету послуг, технологій 3D друку, енергоефективних технологій українські промислові підприємства знаходяться на порозі четвертої промислової революції. Сучасною європейською концепцією промисловості $\epsilon$ інноваційне промислове виробництво Індустрія 4.0 (Industry 4.0), яке представляє собою функціонування кіберфізичних систем 3 використанням промислового інтернету речей. Індустрія 4.0 поєднує у собі сучасну механіку, електроніку та інформаційні технології [1]. Індустрія 4.0 - це ініціатива федерального уряду Німеччини для розвитку економіки країни 3 метою прискорення технологічних змін та утримання німецького лідерства в світовій конкуренції. Планується перехід від звичайної автоматизації виробництва, використання інформаційних технологій у виробництві до об'єднання в мережу ресурсів, інформаційних потоків, об'єктів та людини [2]. Швидкий перехід промисловості України до постіндустральної економіки буде визначатися активною інноваційною діяльності усіх учасників платформи Industry 4.0.

Важливими складовими екосистеми платформи Industry 4.0 є відкриті творчі лабораторії, які дозволяють вивести власний продукт на ринок, оминувши традиційні ланцюжки «інвестор-виробник-вендор». В Україні такі лабораторії були відомі як мейкерспейси, хакерспейси та відкриті лабораторії електроніки, деякі 3 них беруть початок 
ще від гуртків моделювання та раіоблюбителів. У 2014 році в Україні розпочато створення універсальних стандартизованих інноваційних лабораторій цифрового виробництва Фаблаб (FabLab). Фаблаб лабораторії - це невелика лабораторія 3 декількома інструментами цифрового виробництва, що включають 3D-принтери, фрезерні верстати 3 числовим програмним керуванням (ЧПК), машину лазерного різання, засоби електронного прототипування, комп'ютерне оснащення для 3D моделювання.

У 2018 році у Тернопільському національному технічному університеті імені Івана Пулюя відкрито інноваційну лабораторію FabLab в рамках європейського проекту програми Еразмус+ “Створення мережі та інфраструктури підтримки молодіжного інноваційного підприємництва на платформі фаблабів”. Лабораторія FabLab в THTУ обладнана відповідно до вимог світової асоціації Fab Foundation, 3D принтерами, лазерним та фрезерним верстатами з ЧПК, 3D сканером, які об'єднані з комп'ютерними станціями автоматизованої системи технологічної підготовки виробництва на базі сучасного програмного забезпечення.

У 2017 році було проведено аналіз стану креативної економіки в різних областях України за методикою Річарда Флориди [3, 4]. В результаті моніторингу індексу толерантності, талантів та технологій виділено чотири кластери областей за рівнем креативності. У перший кластер з високими рівнями усіх індексів увійшли Харківська та Дніпропетровська області. Зазначено [4], що це регіони 3 тривалими університетськими традиціями та значною кількістю науково-освітніх центрів. У цих регіонах велика кількість талановитої молоді після закінчення вищих навчальних закладів частіше за все працевлаштовується саме в так звані креативні індустрії. У другому кластері з високими та середніми індексами толерантності та талантів та низьким індексом технологій Закарпатська, Луганська, Львівська, Одеська та Чернівецька області. У третьому кластері з низьким рівнем індексів толерантності та таланту і середнім рівнем індексу технологій - Житомирська, Полтавська, Сумська, Херсонська, Хмельницька та Черкаська області. Інші області увійшли до четвертого кластеру 3 низькими значеннями індексів толерантності, талантів та технологій.

Характерною ознакою для регіонів першого та другого кластеру креативності в Україні $є$ наявність відритих креативних лабораторій, в тому числі на платформі Фаблаб. На даний час, Фаблаб лабораторії функціонують у Харкові, Києві, Одесі, Тернополі та Сєвєродонецьку. Такий результат показує високий потенціал даних регіонів з розвитку креативних індустрій у даних регіонах. Можливий швидкий перехід до першого кластеру креативності для прикладу і Тернопільської області, враховуючи іiі четверте місце за індексом нвестицій в науку та друге за індексом цінностей серед усіх регіонів України [4]. Фукціонування відкритих лабораторій цфирового виробництва на платформах Фаблаб також може викорстовуватись як важливий індикатор розвитку креативної економіки у окремому регіоні.

\section{Перелік використаних джерел:}

1. Скіцько В. І. Індустрія 4.0 як промислове виробництво майбутнього / В. І. Скіцько // Інвестиції: практика та досвід. - 2016. - № 5. - С. 33-40.

2. Шварцкопф Т. Индустрия 4.0 - стратегия поддержки инновационной промышленности в федеральной земле Северный Рейн-Вестфалия. Возможности для международных компаний [Електронний ресурс] / Т. Шварцкопф // II Форум бизнеса СевероЗапада, 15 октября 2015. - Режим доступу: www.kvs.spb.ru/ userfiles/003.pdf

3. Флорида Р. Креативный класс: люди, которые меняют будуще / Р. Флорида. М.: Издательский дом «Классика-ХХ1», 2007. - 421 с.

4. Сотнікова Ю. В. Креативна економіка в Україні: реальність чи перспектива? / Ю. В. Сотнікова // Вісник Національного університету водного господарства та природокористування. Економічні науки. - 2016. - Вип. 3. - С. 178-189. - Режим доступу: http://nbuv.gov.ua/UJRN/Vnuvgp_ekon_2016_3_22. 
Мармуль Лариса

доктор економічних наук, професор професор кафедри економіки ДВНЗ «Переяслав-Хмельницький ДПУ імені Григорія Сковороди» м. Переяслав-Хмельницький, Україна

Леваєва Людмила кандидат економічних наук, доцент доцент кафедри економіки ДВНЗ «Переяслав-Хмельницький ДПУ імені Григорія Сковороди» м. Переяслав-Хмельницький, Україна

Larisa Marmul

Doctor of Economics, Professor Professor in the Department of Economics Pereiaslav-Khmelnytskyi Hryhorii Skovoroda State Pedagogical University Pereiaslav-Khmelnytskyi, Ukraine Ludmila Levaieva Ph.D. Associate Professor in the Department of Economics Pereiaslav-Khmelnytskyi Hryhorii Skovoroda State Pedagogical University Pereiaslav-Khmelnytskyi, Ukraine

\section{СТРАТЕГІЧНІ НАПРЯМИ РОЗВИТКУ КОНКУРЕНТОСПРОМОЖНОСТІ В АГРАРНИХ ПІДПРИЕМСТВАХ STRATEGIC DIRECTIONS OF COMPETITIVENESS DEVELOPMENT AT THE AGRARIAN ENTERPRISES}

Стратегічне управління формує основи концепції інтегрального підходу до обгрунтування ефективного функціонування галузей та видів діяльності в ринкових умовах господарювання. В такому розумінні воно дозволяє порівнювати цілі та завдання розвитку галузей, які відображають орієнтацію їх у контексті адаптації до зовнішнього середовища (які знаходять вираз у діях щодо уникнення (пом'якшення) загроз і розвитку можливостей), 3 потенціалом, який є в наявності і якого можна досягти; проводити процес формулювання стратегії відповідно до внутрішніх та зовнішніх можливостей конкурентоспроможного розвитку галузей та видів діяльності в досягненні цілей; організувати і стимулювати діяльність галузей щодо досягнення цілей на основі забезпечення виконання розроблених стратегій.

Ми вважаємо, що стратегічне управління розвитком галузей агропродовольчої сфери в умовах інноваційно-інвестиційного забезпечення дає можливість вирішувати комплекс проблем, пов'язаних з цілеспрямованою їх переорієнтацією на випуск продукції нової номенклатури та асортименту; впровадження та використання новітніх технологій; оволодіння комплексним управлінням інноваціями; формування виробничого потенціалу, необхідного для досягнення стратегічних цілей; перебудову виробничої структури; розвиток спеціалізації та кооперації у сфері збуту та обслуговування споживачів; розвиток маркетингу; удосконалення організаційних структур управління; своєчасну та якісну підготовку та перекваліфікацію персоналу та ін., тобто на те, що має сприяти розвитку галузей в цілому, формуючи їх корпоратизацію та збільшуючи капіталізацію.

На нашу думку, різновидами стратегічного управління розвитком галузей агропродовольчої сфери та суб'єктів їх господарювання у широкому сенсі є: стратегічне планування; управління на основі вибору стратегічних позицій конкурентоспроможності; управління вирішенням стратегічних завдань; управління за допомогою реалізації 
надзвичайних заходів щодо розвитку галузей та їх підприємств тощо. Сутність стратегічного управління конкурентоспроможністю галузі дає відповіді на такі важливі питання: 1. У якому положенні та або інша галузь, вид діяльності знаходиться зараз? 2. У якому положенні воно хотіло б знаходитися в майбутньому? 3. Яким способом досягти бажаного результату?

Для відповіді на перше питання необхідно розуміти поточну ситуацію, у якій знаходиться галузева діяльність, проблеми та тенденції, які їх супроводжують. Для цього важливо здійснювати постійний моніторинг зовнішнього і внутрішнього середовища галузей агропродовольчої сфери з метою розпізнання та адекватного реагування на всі зміни, що відбуваються. Друге питання відображає важливу особливість стратегічного управління розвитком галузі - ii орієнтацію на майбутнє. Відповідь на нього передбачає чітке визначення того, до чого прагне галузь, які ставить цілі перед собою, які формує стратегії досягнення конкурентоспроможності.

Третє питання стратегічного управління розвитком галузей агропродовольчої сфери пов'язане з налагодженням діяльності з реалізації обраної стратегії, ії контролем і оцінкою. У ході здійснення даного етапу можливе корегування двох попередніх. Цим питанням відповідають три основні фази стратегічного управління конкурентоспроможністю: стратегічний аналіз, стратегічний вибір і реалізація стратегії. Виходячи 3 проведеного аналізу стратегічного управління розвитком галузей продовольчої сфери, пропонуємо алгоритм стратегічного управління конкурентоспроможністю, зображений на рис. 1.

Як ми бачимо, аналіз зовнішнього середовища відображається окремим етапом, а також знаходиться над усім процесом стратегічного управління розвитком галузей агропродовольчої сфери. Аналіз, прогнозування та моніторинг зовнішнього середовища також можемо уявити окремо у вигляді базису, на якому будується модель стратегічного управління конкурентоспроможності. Це пов'язано з тим, що оцінку зовнішнього оточення необхідно здійснювати постійно. При такому підході, по-перше, збільшується ступінь контролю над змінами у зовнішньому оточенні, адже аналіз середовища здійснюється паралельно 3 кожним етапом, а по-друге, забезпечується відповідність методологічним принципам сучасного стратегічного управління розвитком переробних підприємств, який полягає у побудові стратегії від майбутнього через минуле до теперішнього (прогнозування аналіз - моніторинг). Аналіз зовнішнього оточення передбачає вивчення економічної, політичної ситуацій, правового середовища, географічного середовища, екологічного стану тощо. 


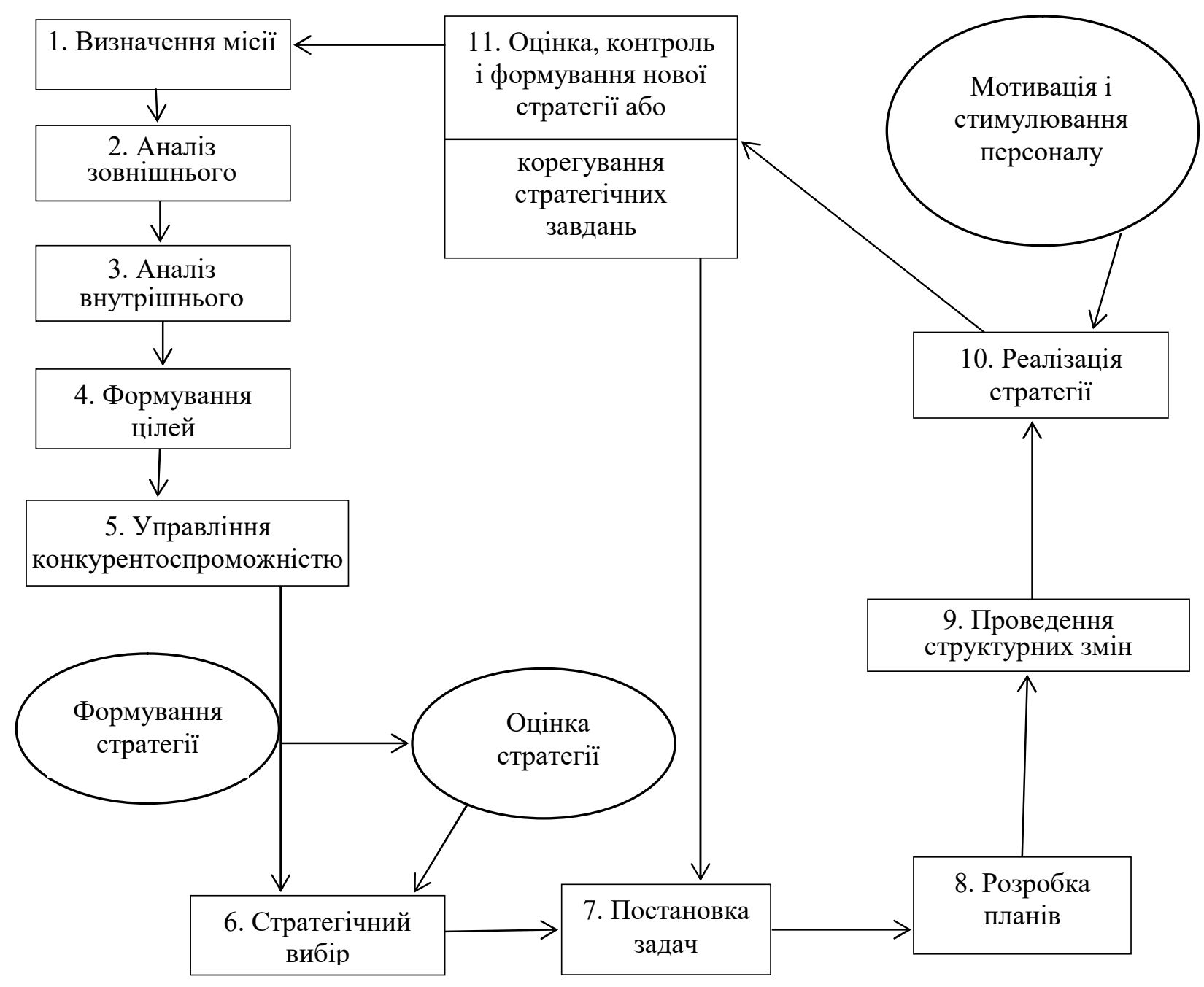

Рис. 1. Рекомендований алгоритм стратегічного управління розвитком галузей агропродовольчої сфери (розроблено авторами)

3 урахуванням результатів, отриманих у ході проведення аналізу зовнішнього середовища, визначається місія галузей агропродовольчої сфери. Вивчення безпосереднього оточення переробних підприємств спрямоване на аналіз стану тих компонентів, з якими вони знаходяться у безпосередній взаємодії, це: джерела сировини, переробні потужності, виробничі потужності, готова продукція, конкуренти, посередники, споживачі. Внутрішнє середовище визначає потенціал і можливості, якими розпоряджаються галузі.

Стратегічне управління розвитком галузей агропродовольчої сфери та видів діяльності можна визначити як концепцію інтегрального підходу до їх діяльності, яка дозволяє: порівнювати цілі розвитку підприємства, які відображають процес його адаптації до навколишнього середовищі, а у т. ч. на світовому ринку, з виробничо-ресурсним потенціалом, який $\epsilon$ в наявності та задіяний на даний момент; проводити процес формування (розробки) комплексу стратегій відповідно внутрішніх можливостей галузевого розвитку у досягненні поставлених завдань; організувати та активізувати діяльність 3 реалізації прийнятих стратегій, особливо корпоратизації, капіталізації, кластеризації на інноваційноінвестиційних засадах. 


\section{Нагорняк Галина}

к.Т.н., доцент

доцент кафедри управління інноваційною діяльністю та сферою послуг Тернопільський національний технічний університет імені Івана Пулюя

м.Тернопіль, Україна

Малюта Людмила

д.е.н., доцент

професор кафедри управління інноваційною діяльністю та сферою послуг

Тернопільський національний технічний університет імені Івана Пулюя

м.Тернопіль, Україна

Атаманов Ігор

студент групи БУм-51

Тернопільський національний технічний університет імені Івана Пулюя

м.Тернопіль, Україна

Halyna Nahorniak

$\mathrm{PhD}$, Docent

Assosiate Professor of Management of Innovative Activities and Services Department

Ternopil Ivan Puluj National Technical University

Ternopil, Ukraine

Ludmyla Maluta

Doctor of Sciences (Economics), Docent

Assosiate Professor of Management of Innovative Activities and Services Department

Ternopil Ivan Puluj National Technical University

Ternopil, Ukraine

Igor Atamanov

student of group БУ $У_{M-51}$

Ternopil Ivan Puluj National Technical University

Ternopil, Ukraine

\section{ІНТЕЛЕКТУАЛЬНИЙ КАПІТАЛ ЯК УМОВА СТАНОВЛЕННЯ КОНКУРЕНТНИХ ПЕРЕВАГ ВІТЧИЗНЯНИХ ПІДПРИЕМСТВ INTELLECTUAL CAPITAL AS THE CONDITIONS FOR COMPETITIVE ADVICE OF DOMESTIC ENTERPRISES}

До середини минулого століття швидкість глобального соціально-економічного розвитку була обумовлена впливом науково-технічного прогресу (основного результату когнітивної активності суспільства), але були й обмежуючі фактори (експлуатація окремих націй (рас); виключення з економічного обміну ряду країн; економічна, технологічна, політична та соціальна автотрофність окремих держав тощо). I лише 3 формуванням загального ринкового простору та усуненням галузевих й інших кордонів науково-технічний прогрес істотно стимулював глобальний соціально-економічний розвиток. Цінності особистості (громадянина та людини) стали домінуючими, у тому числі, їх декларативно підтримували не лише демократичні, але й тоталітарні держави (наприклад, колишній СРСР). У сучасному суспільстві інформація та знання є важливим видом ресурсу. Від вміння людини працювати з інформацією, освоювати нові знання різноманітних видів залежить іiі життєва успішність й економічна ефективність підприємства, у якому вона працює. Звідси випливає важливість інтелектуальної діяльності людини, та, відповідно, значення іiі інтелекту. 3 економічної точки зору, сам інтелект людини та продукти його інтелектуальної діяльності розглядаються, як основний вид капіталу - інтелектуальний капітал, оскільки вони приносять людині економічне благо. 
3 врахуванням вище зазначеного, дана проблематика висвітлена у наукових працях таких провідних учених, як: Б. Андрушків, Н. Кирич, Н. Маркова, Г. Островська, О. Павликівська, О. Погайдак, О. Торба, Р. Шерстюк $[1,2,6]$ була предметом наших попередніх досліджень [3-5]. Таким чином, інтелектуальний капітал - це вид капіталу, який містить інтелект соціального суб'єкта (людини, групи людей, підприємства, суспільства) та продукти його діяльності - інформацію та знання, які володіють новизною, які мають соціально-економічну цінність та які забезпечують йому дохід (благо) та конкурентні переваги. При цьому під інтелектом слід розуміти сукупність пізнавальних та творчих здібностей соціального суб'єкта.

Інтелектуальний капітал людини (іншими словами, індивідуальний інтелектуальний капітал або інтелектуальний капітал особистості) складається з двох основних частин:

- індивідульний інтелект людини, невіддільний від свого носія, який характеризується певними властивостями, рівнем розвитку і який $є$ основою капіталу;

- інтелектуальні напрацювання людини, які знаходять практичне застосування та які мають певну цінність як для неї самої, так і для соціальних суб'єктів.

Розуміємо, що стратегічний (або критично важливий) ресурс - це людський ресурс і в цілому інтелектуальний капітал підприємства, який, на відміну від фінансового та фізичного капіталу, не підкоряється законам простого та розширеного виробництва, оскільки:

- формування інтелектуального капіталу багато у чому залежить від розвиненості професійних компетенцій персоналу підприємства;

- у свою чергу, професійні компетенції персоналу підприємства - це не лише знання, вміння, навички, а також інші здібності співробітників, але і їх мотивація;

- мотивація співробітників до підвищення власного компетентнісного рівня обумовлена внутрішніми установками індивіда, які можуть перебувати у суперечності 3 цільовими орієнтирами розвитку підприємства (у силу об'єктивних і суб'єктивних причин).

Незважаючи на те, що за витрати вітчизняних підприємств на розвиток персоналу збільшуються, інтелектуалоємність та наукоємність, а також науковіддача національної економіки залишається відносно невисокою: основна частина нового бізнесу ініціюється у торгівлі та сервісній традиційній сфері, інноваційно активними можна вважати не більше $10 \%$ від загальної чисельності підприємств реального сектору. Проблема полягає у тому, що інвестиції е розвиток персоналу (підвищення його компетентнісного рівня) або недостатні, або не враховують того, що між потребами розвитку працівників і потребами розвитку підприємства повинен мати місце консенсус особистісних й організаційних інтересів. Економіка майбутнього - це когнітивна (знаннєва) економіка, яка вимагає адекватного кадрового забезпечення. У цьому контексті важливим $є$ ефективне управління розвитком професійних компетенцій персоналу підприємства 3 метою підвищення вартості інтелектуального капіталу (який, по суті, і $є$ джерело конкурентних переваг, тобто ключових відмінних характеристик бізнес-моделі). Якісні трудові ресурси, що володіють достатнім запасом актуальних на сьогодні знань, є однією з основних чинників переходу до когнітивної та екологічно відповідальної економіки. Тому сучасні підприємства, які орієнтовані на довгостроковий, конкурентоспроможний розвиток, повинні здійснювати пошук таких напрямків кадрової політики, які пов'язані 3 формуванням когнітивного потенціалу працівників.

Уміння підприємця або керівної ланки (менеджменту) підприємства ефективно перетворювати фактори виробництва в економічні вигоди зазвичай прийнято розуміти як стратегічний потенціал, який формує інтелектуальний капітал підприємства та використовується підприємством для створення інтелектуальних активів й отримання економічних, а також неекономічних вигод, недоступних для конкурентів. 3 огляду на високу значущість когнітивної складової бізнесу, пропонується більш детально дослідити сутність і зміст поняття "інтелектуальний капітал" підприємств. Інтелектуальний капітал відіграє суттєву роль у забезпеченні конкурентоспроможності як окремого підприємства, так і загалом національної економіки. 
Найбільш поширене визначення теоретичного змісту поняття "інтелектуальний капітал" наступне: вартість інтелектуальних (знання, вміння, навички) та нематеріальних активів (патенти, об'єкти права інтелектуальної власності, ділова репутація); вартісне вираження кадрового капіталу та інтелектуальної власності підприємства; фінансові відносини з приводу формування та використання знань, інтелектуальних здібностей персоналу, що дозволяє підприємству отримувати економічні вигоди.

Безумовним фактом $є$ те, що основним джерелом формування інтелектуального капіталу $\epsilon$ знання, вміння та навички, якими володіє людина (як кадровий ресурс). Експлуатація ж цих знань, умінь і навичок дозволяє підприємству отримувати додаткові або недоступні для конкурентів вигоди, тобто максимізувати доходи та прибуток.

Інтелектуальний капітал можна також розглядати 3 позиції ресурсної теорії підприємства, в якій здатність підприємства максимізувати вигоди, недоступні для конкурентів, безпосередньо взаємопов'язані з наявністю унікальних (відмінних) ключових компетенцій. Ключові компетенції і є тими необхідними знаннями, які трансформовані в уміння та навички управлінського й операційного персоналу, які забезпечують і досягнення поставлених цілей функціонування та розвитку підприємства, і максимізацію економічних та інших вигод, у тому числі, недоступних для конкурентів. Звідси випливає, що знання $\epsilon$ ресурсом, який формує інтелектуальний капітал, який необхідний для стійкого та конкурентоспроможного розвитку підприємства. Враховуючи те, що знання $\epsilon$ нематеріальним ресурсом, відповідно інтелектуальний капітал необхідно розуміти як сукупність всіх активів і зобов'язань, які не мають грошового (вартісного) вираження, а також всіх активів і зобов'язань, які були сформовані за рахунок інтенсивної експлуатації знаннєвих ресурсів. Ці активи та зобов'язання можуть повністю або частково контролюватися підприємством, але при цьому обов'язково беруть участь у формуванні цінності (вигод), недоступних для конкурентів, і базуються на специфічному знаннєвому peсурсі, яким володіє підприємство i цей знаннєвий ресурс визначає структуру інтелектуального капіталу (рис. 1).

Серед ключових компонент прийнято виділяти наступні:

- техніко-структурну, кадрову, інноваційну, інфраструктурну компоненту;

- лише людську або кадрову та структурну компоненту;

- клієнтську (компоненту відносин), а також людську та структурну компоненти.

У структурну компоненту зазвичай прийнято включати сукупність активів i зобов'язань, що визначають бізнес-модель розвитку підприємства. У клієнтську (або відносницьку) компоненту прийнято включати сукупність організаційних внутрішніх i зовнішніх зв'язків, які визначають взаємодію підприємства 3 персоналом, контрагентами та стейкхолдерами на основі стратегії розвитку, що визначає бізнес-модель. 


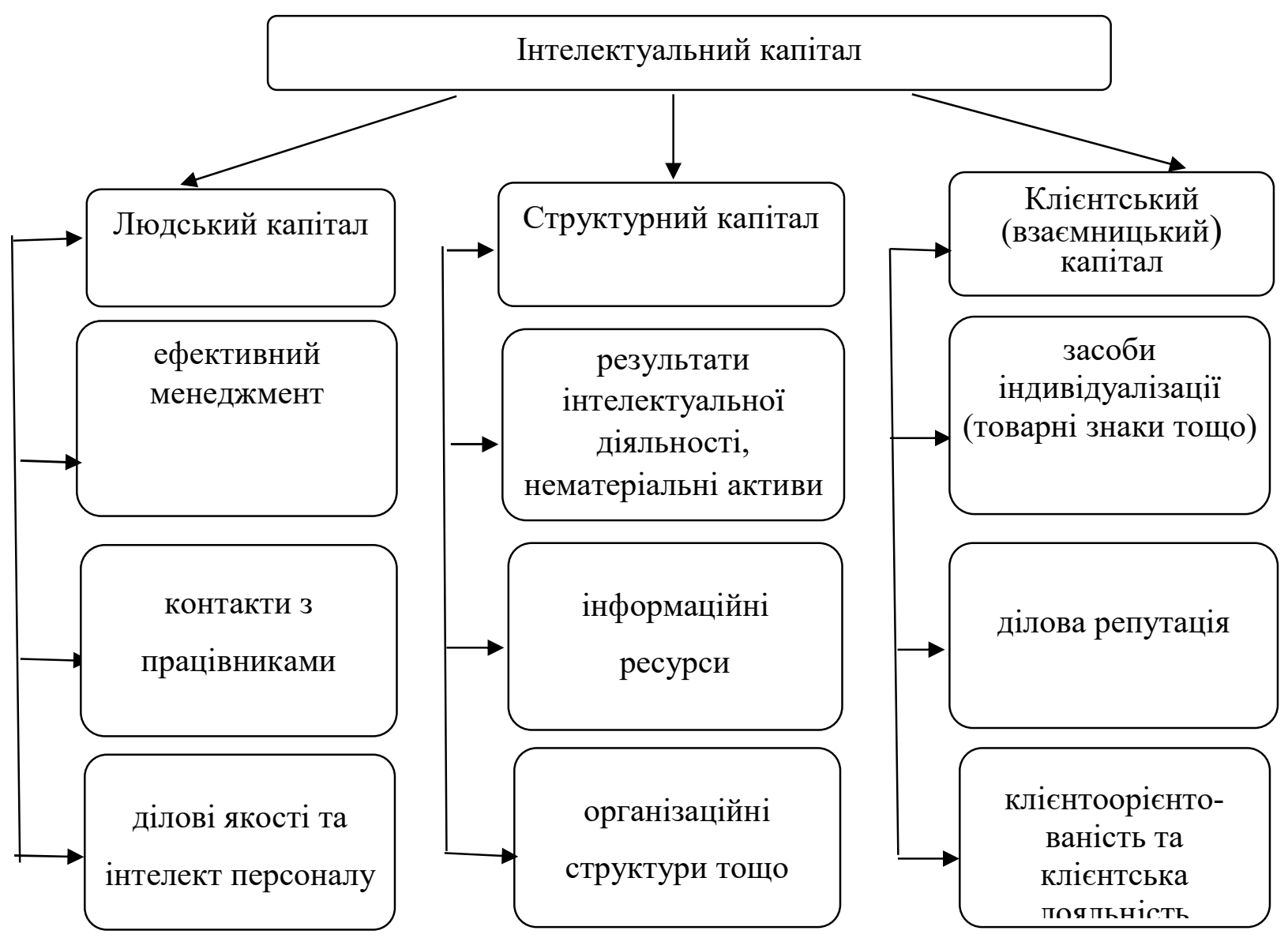

Рисунок 1. Структура інтелектуального капіталу підприємства

У свою чергу, людська компонента представлена кадровими ресурсами підприємства, які є носіями знань, умінь і навичок, необхідних для організування діяльності, встановлення зовнішніх взаємозв'язків, формування активів і зобов'язань, що визначають бізнес-модель підприємства. Варто зазначити, що при визначенні вартості інтелектуального капіталу на практиці, як правило, виникають проблеми 3 оцінюванням взаємницької та кадрової компоненти, оскільки тут необхідно врахувати безліч чинників. Наприклад, якщо оцінювати першу компоненту з позиції витратного або дохідного підходу, то ймовірно, що можна отримати відносно достовірне оцінювання вартості цих компонент. Однак складно іiі оцінювати з позиції ринкового підходу. Отже, враховуючи специфіку компонент інтелектуального капіталу, напрошується висновок, що інтелектуальний капітал - це критично необхідний вид капіталу сучасних підприємств, який поряд 3 фінансовим та фізичним капіталом формує здібності до сталого розвитку з максимізацією економічних вигод підприємства, недоступних для конкурентів. Інтелектуальний капітал визначає оптимальність, раціональність й інтенсивність використання інших видів капіталу (фінансового та фізичного).

Перелік використаних джерел:

1. Андрушків Б. М., Кирич Н. Б., Погайдак О. Б., Шерстюк Р. П. Особливості використання державних важелів управління інноватикою суб'єктів господарювання - як інструментом підвищення їхньої конкурентоспророможності (європейські акценти). Теорія та практика державного управління: зб. наук пр. Х.: Вид-во ХарРІ НАДУ “Магістр”, 2015. Вип. 2 (49). С. 134-143.

2. Андрушків Б. М., Островська Г. Й., Павликівська О. І. Інтелектуальний потенціал підприємства як інструментарій підвищення конкурентоспроможності підприємства та засіб входження його у європейський економічний простір. Держава та регіони: науково- 
виробничий журнал. Серія: економіка та підприємництво. Класичний приватний університет. № 6 (99). Запоріжжя, 2017. С. 38-43.

3. Малюта Л. Я. Діагностика інтелектуально-кадрової складової забезпечення економічної безпеки машинобудівних підприємств. Вісник економічної науки України. 2015. № 1 (28). С. 89-93.

4. Малюта Л. Я., Корныйчук А. В. Гудвіл як інноваційна компонента інтелектуальної складової забезпечення економічної безпеки підприємства. Матеріали XX Міжнародної науково-практичної Інтернет-конференції “Тенденції та перспективи розвитку науки і освіти в умовах глобалізації” (Переяслав-Хмельницький, 27 грудня 2016 року). ПереяславХмельницький, 2016. Вип. 20. 233 с. С. 64-66.

5. Нагорняк Г. С. Концептуальні засади вимірювання й оцінювання інтелектуального капіталу вітчизняних машинобудівних підприємств. Галицький економічний вісник. Т.: ТНТУ, 2017. Том 53. № 2. С. 79-89 (Економіка та управління підприємствами).

6. Торба О. Інтелектуальний капітал підприємств: сутність, оцінка, структура. Вісник Дніпропетровського університету. Серія “Економіка”. 2016. Т. 24, Вип. 10 (2). С. 97-105.

УДК 005.336.4

Нагорняк Ірина

старший викладач

Тернопільський національний технічний університет імені Івана Пулюя

м. Тернопіль, Україна

Nahorniak Iryna

Senior Lecturer

Ternopil Ivan Puluj National Technical University

Ternopil, Ukraine

\section{ЗМІСТ ЕКОНОМІЧНОГО ІНТЕЛЕКТУАЛЬНОГО КАПІТАЛУ ЯК ЧИННИКА ПОСИЛЕННЯ КОНКУРЕНТОСПРОМОЖНОСТІ СУЧАСНОГО ПІДПРИЕМСТВА THE CONTENT OF ECONOMIC INTELLECTUAL CAPITAL AS A FACTOR IN INCREASING THE COMPETITIVENESS OF MODERN ENTERPRISES}

Економічний інтелект $є$ кінцевою ланкою в ланцюгу інтелектуальних цінностей, котрий сформований іншими видами інтелекту, створюючи кінцеву реальну цінність. В структурі економічного інтелекту в першу чергу слід розглядати розуміння і бачення того, як можна використовувати у сфері підприємницької діяльності з вигодою для себе вже наявний природний та штучний інтелект 3 врахуванням існуючих матеріальних та фінансових ресурсів, а також соціально-економічної ситуації в глобальному та локальному масштабі.

Це економічне бачення, основою якого є певні визначені підприємницькі здібності, посилюється за наявності теоретичних та практичних предметних знань, вмінь та навиків, за допомогою яких здійснюється інтелектуальна діяльність у певній сфері підприємництва.

Обов'язковою складовою економічного інтелектуального капіталу попри такі риси характеру як воля, скерованість, цілеспрямованість, відповідальність, стресостійкість, внутрішня мотивація росту та розвитку, є наявність знань та вмінь в галузі економіки та менеджменту організації, самоменеджменту.

Кінцевий результат реалізації інтелектуального капіталу $є$ успішне влаштування людини в реальний світ або перетворення його з вигодою як для себе, так і для суспільства у цілому.

Отже, інтелектуальний капітал можна визначити як сукупність інтелектуальних здібностей, знань і вмінь людини по перетворенню свого внутрішнього, а також зовнішнього світу на основі створення ментальних моделей з отриманням бажаної економічної вигоди [1]. 
Економічний інтелектуальний капітал можна також назвати капіталом підприємництва, оскільки його наявність створює передумови успішної економічної діяльності людини, іiї благоустрою, а також засади забезпечення конкурентоспроможності підприємства у цілому.

В сучасному суспільстві набирає актуальності потреба гармонійного поєднання двох типів інтелектуального капіталу - капіталу ментального, сформованого самою людиною (капітал сприйняття, мислення, емоційна, креативна складові) та капіталу, що формується у взаємодії з іншими людьми (це соціальний та економічний види капіталу).

При формуванні цілісного, гармонійного інтелектуального капіталу особистості безумовно потрібно мати те, що можна пред’явити людям, тобто має суспільну цінність. Для утворення економічного інтелектуального капіталу, перш за все, повинна бути поставлена соціальна взаємодія, тобто бути сформованим соціально-культурний капітал. При цьому створення креативного капіталу доцільно здійснювати у максимальній взаємодії 3 людьми, будуючи основу для формування соціально-економічного капіталу.

Для більш грунтовного аналізу змісту поняття «економічний інтелект» слід відділити це поняття від традиційного «практичного інтелекту».

Р.Стернберг визначає практичний інтелект як засіб набуття людиною досвіду, виділивши самостійність мислення як його основну рису [2]. Економічний інтелект є більш змістовним поняттям, оскільки він ще включає в себе здібності та вміння орієнтації в економічному просторі реальної дійсності, що представляє собою інтерес 3 точки зору забезпечення конкурентоспроможності організації. У цьому сенсі спеціаліст певної сфери діяльності також поєднує в собі економіста та підприємця, незалежно від посади, яку він займає. В кінцевому результаті це приносить вигоду як працівнику, так і його організації, сприяє посиленню конкурентних позицій та зростанню доходності. Оскільки, до прикладу, технолог чи конструктор, володіючи економічним мисленням, при прийнятті рішень буде керуватись не лише технічними знаннями у певному питанні, але й оцінювати його економічну доцільність, тобто враховуватиме економічну і споживчу вигоду від прийняття певного рішення. Більше того, такі працівники виявляють себе як інноваційні інтрапідприємці (внутрішньофірмові підприємці), отримуючи додаткову індивідуальну винагороду від розроблених ними рацпропозицій, що є серйозним стимулом до творчої діяльності та фактором забезпечення розвитку та конкурентоспроможності підприємства.

Варто наголосити на необхідності включення економічного інтелекту в інтегральну структуру інтелекту. Такий підхід на сьогодні є альтернативою домінуючій суспільній думці, що життєвий успіх визначається не інтелектуальними здібностями людини, а такими властивостями як напористість, нехтування інтересами людей заради власної вигоди, гіпертрофовані матеріальні потреби, прагнення необмеженої влади, любов до грошей як особливої цінності.

Широке поширення підходу до формування інтегрованого інтелектуального капіталу особистості дозволить створити в суспільстві моду на інтелектуальність, але не абстрактну, у чистому вигляді, а таку, яка дає економічну вигоду людині або організації без нанесення шкоди іншим людям, більше того - 3 привнесенням додаткової користі в суспільний розвиток та формування конкурентних позицій.

Володіння доступом до найважливішого ресурсу - економічного інтелекту - в сучасних умовах представляє собою шлях створення конкурентних переваг підприємства. Отже, знання, як основа економічного інтелектуального капіталу, становлять найбільш важливий ресурс, а здатність отримувати, інтегрувати, накопичувати, зберігати i застосовувати їх $є$ найбільш важливим способом створення конкурентних переваг.

\section{Перелік використаних джерел:}

1. Нематеріальна економіка та управління формуванням і використанням інтелектуального капіталу. Навчальний посібник / Л. С. Шевченко. - Харків, 2013. - 352 с.

2. Вступ у психологію / Під заг. редакцією В. П. Зінченко. 15-е міжнародне видання. Санкт-Петербург: Прайм-Сврознак. - 2007. - 272 с. 
ДВНЗ «Тернопільський коледж харчових технологій і торгівлі», Тернопіль, Україна

Науковий керівник: Березівська Надія викладач вищої кваліфікаційної категорії ДВНЗ «Тернопільський коледж харчових технологій і торгівлі»

Yana Novik student group 3-M-9/9 State Higher Educational Establishment «Ternopil College of Food Technology and Trade», Ternopil, Ukraine

Scientific supervisor: Nadiya Berezivska, teacher of higher qualification category

State Higher Educational Establishment «Ternopil College of Food Technology and Trade»

\section{ІННОВАЦЙНИЙ РОЗВИТОК ОСВІТНЬОГО ПРОСТОРУ INNOVATIVE DEVELOPMENT OF EDUCATIONAL SPACE}

Під інноваційним розвитком освіти слід розуміти комплекс створених та запроваджених організаційних та змістових нововведень, розвиток низки факторів та умов, необхідних для нарощування інноваційного потенціалу освітньої системи. Такий складний психолого-педагогічний процес вимагає чітко спланованих системних дій 3 боку всіх освітянських структур, які в своїй сукупності складають основу інноваційної політики [3].

Отримання освіти $є$ невід'ємною частиною еволюції суспільства. Тому природним $\epsilon$ прагнення до розвитку і вдосконалення системи освіти в усьому світі. Для того, щоб їі якість відповідала сучасним вимогам, необхідно постійно вдосконалювати концепцію іiі модернізації, обов'язковою умовою якої має бути наявність реформ [4].

Сучасна освіта і особливо загальноосвітня школа під впливом науково-технічного прогресу та інформаційного буму вже досить довго перебувають у стані безперервного організаційного реформування та переосмислення усталених психолого-педагогічних цінностей. В той же час реальні психологічні процеси у житті нинішніх поколінь, особливо молоді, яка стоїть на порозі самостійного професійного життя, свідчать про те, що освіта серйозно відстає від потреб життя. Зумовлено це тим, що сучасна освітня парадигма, була сформована в умовах, коли доступ до нової інформації був обмеженим для широкого кола людей, а це стимулювало переважно репродуктивні форми навчання. Традиційно навчальний процес зорієнтований на отримання, в кращому випадку - на творче засвоєння суми знань тими, хто навчається. Освіта формує молодих людей у ролі засвоювачів “готових знань”. До цієї ролі дуже легко і швидко звикають, і тому сучасна освіта виховує, як правило, людейекстерналів, які вміють активно працювати лише під керівництвом і при спонуканні зовнішніми чинниками. Молоді люди, наповнені «готовими знаннями», у своїй більшості не вміють працювати ні творчо, ні самостійно, особливо в умовах, коли знання потребують швидкого оновлення. Слід усвідомлювати, що основні споживачі чужої інтелектуальної праці дуже швидко опиняються на узбіччі соціально-економічного розвитку. Тому молодь необхідно орієнтувати на соціально-культурний розвиток особистості, який дозволить зробити індивіда не тільки професіоналом за обраним фахом, а й культурно розвиненою, високо освіченою людиною та носієм новітніх знань [1].

Зміна політики і соціальних пріоритетів в освіті, i, зокрема в незалежній Україні, сформувала принципово нову мету освіти та виховання: перехід від виховання громадянина країни до формування громадянина світу, людини відкритої, демократичної і відповідальної, освіченість, культура і мораль якої відповідають складності завдань глобалізованого світу.

Сучасна освіта повинна готувати людину, котра здатна жити в надзвичайно глобалізованому і динамічно змінюваному світі, сприймати його мобільність як суттєву 
складову власного способу життя. Глобалізація, трансформаційні процеси та постійна інформаційна мобільність обумовлюють включення людини в дуже складну систему суспільних взаємовідносин, вимагають від неї здатності до нестандартних і швидких рішень. Саме тому основна увага у педагогічних колективах має приділятися питанням подолання консерватизму в підходах до навчально-виховної діяльності та існуючих стереотипів педагогічної праці, до процесу мислення учасників навчання і виховання. Тільки інноваційна за своєю сутністю освіта може виховати людину, яка живе за сучасними інноваційними законами глобалізації, і є всебічно розвиненою, самостійною, самодостатньою особистістю, яка керується в житті власними знаннями і переконаннями. Загалом, це більше потрібно суспільству, ніж освіті чи конкретній людині, бо без всебічно розвиненої особистості неможливо розбудувати ані основ демократії, ані досягти параметрів економічно розвинених країн [2].

Сучасна освіта, крім надання знань має прищепити молодій людині здатність самостійно засвоювати знання, оволодівати потрібною інформацією та творчо осмислювати iii. Тобто освіта має на меті навчити майбутнього громадянина на основі отриманих знань критично і творчо мислити, використовувати знання як у професійній, так і в суспільнополітичній діяльності. Творчо сформована особистість стає активним суб'єктом суспільних відносин.

Удосконалення навчально-виховного процесу здійснюється в контексті таких глобальних освітніх тенденцій:

- масовий характер освіти та іiї безперервність;

- підвищення значущості освіти для індивіда та суспільства;

- орієнтація на активне освоєння людиною способів пізнавальної діяльності;

- адаптація освітнього процесу до запитів і потреб особистості;

- орієнтація на демократизацію всіх освітянських структур;

- орієнтація навчання на інновації, особистість, забезпечення можливостей іiї саморозвитку та саморозкриття, загальні та фахові компетенції;

- людиноцентриське спрямування освіти та гуманістична спрямованість інноваційних процесів;

- підпорядкування організаційних, структурних та змістових нововведень в навчально-виховному процесі принципу “освіта упродовж всього життя”;

- пріоритетність фінансування освіти [5].

\section{Перелік використаних джерел:}

1. Химинець В.В.Інновації в сучасній школі / В.В.Химинець. - Ужгород: Економічна освіта, 2003. - $124 \mathrm{c}$.

2. Химинець В.В.Інноваційно-освітня діяльність / В.В.Химинець. - Ужгород: Друкарня, 2007. - 98 с.

3. http://klasnaocinka.com.ua/uk/article/chornova-versiya-statti-59.html

4. https://buki.com.ua/blogs/Vplyv-naukovo-tekhnichnoho-prohresu-na-systemu-osvity/

5. http://journal.osnova.com.ua/article/39577-Підвищення_ефективності_навчальновиховного_процесу_шляхом_упров 
Пілічева Марина

к.т.н., доцент кафедри

земельного адміністрування та геоінформаційних систем

Харківський національний університет міського господарства імені О. М. Бекетова

Maryna Pilicheva

Ph.D., Associate Professor of The Department

Of Land Administration and Geoinformation Systems

O. M. Beketov National University of Urban Economy in Kharkiv

\section{ОБЛІК ЗЕМЕЛЬ - ОСНОВА ЕФЕКТИВНОГО УПРАВЛІННЯ ЗЕМЕЛЬНИМИ РЕСУРСАМИ \\ THE LAND ACCOUNTING - THE BASIS OF THE EFFECTIVE LAND RESOURCES MANAGEMENT}

Облік земель в Україні розглядається як державний захід щодо накопичення, систематизації й аналізу всебічних відомостей про кількість, розміщення, господарське використання земельних ресурсів та їх природний стан і ведеться з метою: забезпечення державного факту виникнення або припинення існування об'єкту обліку; державного обліку земель та контролю за їх використанням і охороною; державного управління земельними ресурсами; планування і регулювання раціонального використання земельних ресурсів; оцінки земель і встановлення обгрунтованої плати за землю; забезпечення державної реєстрації прав на нерухомість і угод з нею; захист прав громадян і юридичних осіб на землю; інформаційного забезпечення цивільного обігу земель [1].

Він проводять за фактичним станом використання угідь на основі якісних картографічних матеріалів і даних обліку поточних змін, виявлених у натурі і відображених графічним способом на земельному плані.

Облік земель ведеться за окремими земельними ділянками, власниками землі i землекористувачами, у тому числі орендарями. При цьому виділяють землі населених пунктів та землі поза ними. Це переважно землі сільськогосподарського призначення, лісового фонду, які виступають головним засобом виробництва відповідно в сільському й лісовому господарств.

Земельно-обліковою одиницею є земельна ділянка - частина земної поверхні 3 установленими межами, певним місцем розташування, з визначеними щодо неї правилами, яка має ідентифікаційний (кадастровий) номер [1].

Існуючі методичні підходи до обліку земель складаються з єдино спрямованих за змістом принципів і методів. До принципів обліку земель відносять:

- принцип своєчасності та безперервності ведення обліку земель;

- принцип систематичного обліку кількісних і якісних змін у стані;

- принцип єдності системи і технологій ведення обліку земель.

Також використовуються наступні методи:

- статистики - метод заснований на статистичній обробці кількісного матеріалу, зібраного у результаті інших досліджень (спостережень, експериментів, моделювань), що дозволяє його всебічно проаналізувати та встановити певні закономірності;

- заходи щодо землеустрою, спеціальних і інших видів обстежень - це особливий вид землевпорядних дій підготовчого характеру;

- методи топографічних, кадастрових та інших зйомок.

Облік земель ведеться за системою, яка складається 3 трьох рівнів: базовий, регіональний і національний. 
На базовому рівні визначаються і зберігаються відомості про земельні ділянки, їх розподіл серед власників землі, землекористувачів, у тому числі орендарів, про правовий режим земельних ділянок, їх кількісну та якісну характеристику і оцінку земель.

На регіональному рівні визначаються і зберігаються відомості про межі адміністративно-територіальних утворень (сіл, селищ, міст, районів, області), про правовий режим земель, їх розподіл за категоріями та господарським використанням, про їх кількісну та якісну характеристику і оцінку земель.

На національному рівні визначаються і зберігаються відомості про державний кордон України, межі Автономної Республіки Крим, областей та міст Києва і Севастополя, про правовий режим земель, їх розподіл за категоріями та господарським використанням, про їх кількісну та якісну характеристику і оцінку земель.

На базовому рівні, який $є$ вихідним, розробляється і впроваджується текстова земельно-кадастрова документація (форми адміністративної звітності з кількісного обліку земель (форми № 11-зем, 12-зем, 15-зем, 16-зем [2]). Одержані земельно-облікові дані узагальнюються на наступних рівнях і ведуться в автоматизованому режимі.

Для визначення просторового аспекту обліку земель у більшості країн світу розроблені та реалізуються програми створення національних інфраструктур геопросторових даних (НІГД), які об'єднують усі ланки і види забезпечення виробництва, постачання та використання геоінформаційних ресурсів на базі Державного земельного кадастру як основи цілісної системи геопросторових даних [3]. НІГД спрямована на удосконалення системи забезпечення потреб суспільства у всіх видах географічної інформації, підвищення ефективності використання геопросторових даних та геоінформаційних технологій в системах підтримки управлінських рішень органів державної влади та місцевого самоврядування.

Впровадження НІГД дасть можливість знизити трансакційні витрати 3 пошуку, аналізу інформації та підвищити ефективність прийняття управлінських рішень у режимі реального часу, сприятиме сталому розвитку нашої держави, який є неможливим без повного та актуального розуміння змін, які відбуваються у земельних ресурсах.

\section{Перелік використанних джерел:}

1. Шипулін В.Д. Система земельного адміністрування: основи сучасної теорії : навч. посібник / В. Д. Шипулін ; Харків. нац. ун-т міськ. госп-ва ім. О. М. Бекетова. Харків : ХНУМГ ім. О. М. Бекетова, 2016. - 220 с.

2. Наказ Міністерства регіонального розвитку, будівництва та житловокомунального господарства України «Про затвердження форм адміністративної звітності 3 кількісного обліку земель (форми № 11-зем, 12-зем, 15-зем, 16-зем) та Інструкцій щодо їх заповнення» № 33730.12 .2015 р. // Офіційний вісник України від 01.03.2016 — 2016 р., № 15, стор. 124, стаття 601, код акту 80785/2016.

3. Курильців Р. М. Концептуальні засади формування системи адміністрування землекористування в Україні / Р. М. Курильців // Economics Bulletin. - 2016, № 3. - С. 154161. 


\section{Семчишин Свгенія}

викладач економічних дисциплін Технічний коледж ТНТУ ім.І.Пулюя

м. Тернопіль, Україна

Смачило Ліля

студент

Технічний коледж ТНТУ ім.І.Пулюя

м. Тернопіль, Україна

Yevheniia Semchyshyn teacher of the highest category

Technical College of Ternopil Ivan Puluj National Technical University

Ternopil, Ukraine

Lilia Smachylo student

Technical College of Ternopil Ivan Puluj National Technical University

Ternopil, Ukraine

\section{УКРАЇНА В СИСТЕМІ СВІТОВОЇ КОНКУРЕНТОСПРОМОЖНОСТІ UKRAINE IN THE WORLD COMPETITIVENESS SYSTEM}

У XXI столітті в світовому ринку важливий розвиток забезпечує національна конкурентоспроможність, яка зазнає істотного впливу у будь-якій країні в глобальній конкуренції. У ринковій економіці найактуальнішою проблемою, що постає перед Україною $\epsilon$ напрямки підвищення конкурентоспроможності та завоювання міцних позицій на міжнародному ринку. В економіці забезпечення конкурентоспроможності $є$ пріоритетним завданням будь-якої держави, яка дбає про місце на світовому ринку та своє економічне зростання. Конкуренція примушує підприємства всіх форм власності постійно відстежувати зміни вартості матеріальних ресурсів, попиту та пропозиції, зменшувати витрати на виробництво, покращувати якість своєї продукції та послуг, що реалізуються на ринку, ідвищувати свою конкурентоспроможність.

Слід зазначити, що значний вклад у дослідженні конкурентоспроможності внесли зарубіжні та вітчизняні економісти А. Сміт, Ж. Ламбен, Дж. Странд, Д. Рікардо, П. Рапкін Х. А. Фасхієва, М. Г. Долинська, Г. Л. Азоєв, А. Градов, С. М. Ілляшенко, А. Е. Воронкова, Г. М. Скудар, В. М. Осипова. Разом із тим проблеми конкурентоспроможності залишаються недостатньо обгрунтованими і потребують комплексного вивчення.

Конкурентоспроможність країни виявляється у здатності досягти високих темпів економічного зростання, забезпечити постійне збільшення реальної заробітної плати, просувати на світовий ринок конкурентоспроможні фірми та передбачає наявність сильної конкурентоспроможної економіки, представленої високопродуктивними кластерами, що поліпшують якість товарів і послуг, забезпечують створення нових робочих місць у майбутньому. Здатність адаптуватися до змін, що відбуваються на світовому ринку, базується на таких економічних факторах, як інвестиційні, інноваційні, виробничі потужності та ін. Проте їх дія повинна поєднуватись із політичними та соціальними чинниками, які теж впливають на функціонування національної економіки на світовому ринку [1].

Американські вчені П. Рапкін і Дж. Странд стверджують, що конкурентоспроможність країни $є$ політико-економічною концепцією, яка впливає на військовий, політичний і науковий потенціал країни та є невід'ємним фактором відносних позицій країни в міжнародній політичній економіці. 
Однією з глобалізаційних умов залучення України до міжнародної економічної діяльності, на думку фахівців, є збільшення рівня відкритості національної економіки, а сам процес оптимізації рівня відкритості економік країн пов'язується з визначенням позиції країн у міжнародних рейтингах.

Динаміку зовнішнього бачення економічних зрушень в Україні у період 20102017 років із позицій міжнародного рейтингування наведено в таблиці 1. Індекс глобальної конкурентоспроможності (The Global Competitiveness Index) - масштабне наукове дослідження, яке здійснюється Всесвітнім економічним форумом. Результатом цього дослідження $є$ рейтинг країн світу за показником економічної конкурентоспроможності.

Таблиця 1

Позиція України у міжнародних рейтингах

\begin{tabular}{|c|c|c|c|c|c|c|c|}
\hline \multirow[t]{2}{*}{ Назва рейтингу } & \multicolumn{7}{|c|}{ Місце України в рейтингах } \\
\hline & $\begin{array}{l}\dot{0} \\
\stackrel{2}{\circ} \bar{i}\end{array}$ & 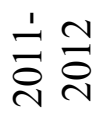 & 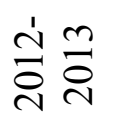 & 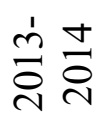 & $\stackrel{\dot{j}}{\stackrel{n}{\circ}} \frac{n}{i}$ & $\stackrel{i}{\frac{1}{2}} \frac{0}{0}$ & 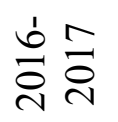 \\
\hline $\begin{array}{l}\text { Індекс глобальної } \\
\text { конкурентоспроможності }\end{array}$ & 89 & 82 & 73 & 84 & 76 & 79 & 85 \\
\hline Індекс ведення бізнесу & 147 & 149 & 152 & 137 & 112 & 96 & 83 \\
\hline $\begin{array}{l}\text { Індекс економічної } \\
\text { свободи }\end{array}$ & 162 & 164 & 163 & 161 & 155 & 162 & 166 \\
\hline $\begin{array}{l}\text { Індекс інвестиційної } \\
\text { привабливості }\end{array}$ & 2,57 & 3,28 & 2,18 & 2,12 & 1,87 & 2,57 & 2,88 \\
\hline
\end{tabular}

Динаміка глобального індексу конкурентоспроможності показала, що позиція України коливається через кризові ситуації. У період 2013-2014 років ситуація покращилась, але подальший посткризовий синдром призвів до зниження конкурентоспроможності країни, а у 2016-2017 рр. Україна посіла 85 місце серед 144 країн світу, піднявшись на 6 позицій порівняно $з$ попереднім роком [2].

На основі спостережень вітчизняних та міжнародних експертів, їх систематизації можна стверджувати, що зниження рівня конкурентоспроможності нашої країни в різних міжнародних рейтингах пов'язане в першу чергу із нестабільною політичною ситуацією в державі, спричиненою агресією Росії. Тривалі військові протистояння на Сході в зоні конфлікту призводять до спаду виробництва, руйнування інфраструктури, зниження економічних показників вцілому. На жаль, така ситуація негативно i надалі відображатиметься на рейтингах світової конкурентоспроможності України.

Крім того, існує низка ще інших стримувальних чинників, які гальмують інвестиційний ринок України і знижують можливі прибутки суб'єктів підприємництва від інвестиційної діяльності. До таких чинників, на які повинні реагувати органи влади доцільно віднести:

- нестабільність існуючого українського законодавства;

- недостатня розвинутість ринкової інфраструктури;

- недостатня результативність діяльності фондового ринку;

- корупційні правопорушення;

- податковий тиск.

Таким чином, основні пріоритети України відносно підвищення конкурентоспроможності на міжнародному ринку мають полягати у впроваджені комплексної системи поступової адаптації вітчизняної економіки до змін інтеграційних та світових глобалізаційних процесів. Проведення внутрішніх реформ та трансформація зовнішньоекономічної політики - це ключові механізми забезпечення конкурентних переваг України. Крім того, зусилля держави потрібно спрямувати на розвиток сприятливих умов 
для ведення бізнесу, що дозволить краще реалізувати наявний людський та інноваційний потенціал і стане основою для підвищення конкурентоспроможності України у міжнародних рейтингах.

\section{Перелік використаних джерел:}

1 Оніщенко I. O. Інвестиційна привабливість України: проблеми та шляхи їх вирішення / I. О. Оніщенко // Траєкторія науки. Електронний науковий журнал. - 2016. № 3 (8) - c. 289-295.

2. Уманців Ю. Економіка України у вимірі глобальної конкурентоспроможності / Ю. Уманців // Вісн. Антимонопольного комітету України. Конкуренція. — 2011. — № 1. — C. 14-23.

УДК $630 * 6(477)$

\section{доктор економічних наук}

член-кореспондент Академії економічних наук України завідувач кафедри деревооброблювальних технологій та системотехніки лісового комплексу

Харківського національного технічного університету сільського господарства ім. Петра Василенка

м. Харків, Україна

Бабич Анатолій

кандидат військових наук, доцент, доцент кафедри теорії та конструкції автомобільної та спеціальної техніки Харківського національного університету повітряних сил ім. І. Кожедуба

м. Харків, Україна Anastasiy Suska

D.Sc, Corresponding Member of the Academy of Economic Sciences of Ukraine, Head of the Department of Woodworking Technologies and Systems Engineering of the Forestry Complex, Kharkiv Petro Vasylenko National Technical University of Agriculture, Ukraine Anatoly Babich $\mathrm{PhD}$, Associate Professor, Department of Theory and Design of Automotive and Special Vehicles, Ivan Kozhedub Kharkiv National University of Air Force, Ukraine

\section{ЕКОЛОГО-ТЕХНІЧНА КОНКУРЕНЦІЯ ЯК ВИД МІЖГАЛУЗЕВОЇ КОНКУРЕНЦЇ̈ ECO-TECHNOLOGICAL COMPETITION AS A FORM OF INTERSECTORAL COMPETITION}

Доступність інформації щодо соціально-екологічних проблем багатьох природних територій України (паводки, радіоактивне забруднення, зсуви грунту, селеві потоки, відрова ерозія грунту, забруднення повітря, суховії та інше), розуміння суспільством ступеня небезпеки таких явищ, а також наявність наукових досліджень, які доводять можливість рішення багатьох таких проблем шляхом використання соціально-екологічного ресурсу лісу, викликало зацікавленість багатьох інвесторів саме в екологічних інвестиційних проектах.

Сутність екологічних інвестиційних проектів полягає у вкладенні капіталу в капіталізацію соціально-екологічного ресурсу лісу та виведенні на ринок нового товару соціально-екологічної послуги, який продукується суб’єктами лісового господарства в 
процесі вирощування, відновлення, збереження лісів, як природних генераторів соціальноекологічного ресурсу.

В значній мірі це приводить до перерозподілу інвестиційного капіталу між галузями економіки, а саме відтоку капіталу з галузей, які декларували рішення екологічних проблем шляхом реалізації технічних проектів (захисні протиселеві, протизсувні споруди, дамби, меліоративні канали тощо), в лісовий сектор економіки, де можливо вирішити значну частину соціально-екологічних проблем використанням соціально-екологічного ресурсу лісу (лісові захисні пояси - смерековий пояс проти каменепадів в Українських Карпатах, проти селевий пояс з насаджень дуба звичайного і дуба скельного в Кримських горах, зони буковограбових насаджень для регулювання водного і кислотного балансу грантів Полісся, зелені зони для захисту населених пунктів в степовій природній зоні України від пилових бур тощо).

Боротьба за інвестиції між різними галузями економіки щодо екологічних чи технічних альтернатив рішення соціально-екологічних проблем визначають такий вид міжгалузевої конкуренції як еколого-технічна конкуренція.

Об’єктом еколого-технічної конкуренції є величина затрат на реалізацію екологічних $\left(3_{e a}\right)$ і технічних альтернатив ( $3_{\text {ота }}$ ) щодо рішення конкретної проблеми за умови досягнення однакового економічного ефекту. Абсолютним показником конкурентоспроможності суб'єктів, носіїв таких альтернатив $\epsilon$ сальдо затрат $\left(C_{3 a}\right)$ на отримання одиночного розрахункового ефекту i визначається як різниця затрат на отримання одиночного розрахункового економічного ефекту при реалізації екологічної альтернативи ( $\left.3_{\text {орее }}^{\text {ea }}\right)$ i таких затрат за умов вибору технічної альтернативи ( $3^{\text {opee }}$ ота $)$ :

$$
C_{\text {за }}=3_{\text {ea }}^{\text {opee }}-3_{\text {oma }}^{\text {opee }}
$$

Величина сальдо 3 позначкою «-» визначає конкурентні переваги екологічної альтернативи, з позначкою «+» конкурентні переваги технічної альтернативи.

Відносним показником конкурентоспроможності, який дозволяє визначити рівень конкурентних переваг, є коефіцієнт еколого-технічної конкуренції $\left(K_{\text {eтк }}\right)$, визначається за виразом:

$$
K_{\text {eтк }}=\frac{3^{\text {opee }}{ }_{\text {ea }}}{3^{\text {opee }}{ }_{\text {oma }}} .
$$

Якщо коефіцієнт менше одиниці - конкурентна перевага екологічної альтернативи по затратам, якщо більше одиниці - екологічна альтернатива більш затратна ніж технічна альтернатива. Переваги екологічних альтернатив полягають в значно меншій вартості реалізації таких альтернатив. Наприклад, аналіз технічних і екологічних проектів щодо рішення проблеми зсуву грунтів у передгір'ях Карпат показав, що для будівництва нагірних водовідвідних каналів на ділянці довжиною 50 кілометрів необхідні кошти близько 500 тис. грн. і близько 70 тис. грн., щорічно, для підтримання цих спору в експлуатаційному стані. В той же час, екологічний проект, який полягає у формування рівня лісистості і структури лісів на цій ділянці, що може забезпечити такий же економічний ефект може нести витрати близько 120 тис. грн. Ризики щодо тривалого терміну повернення інвестицій, у випадку екологічного інвестування, можуть бути значно зменшені такими факторами як: ліси починають продукувати соціально-екологічні блага задовго до того, як деревина набуде необхідної експлуатаційної якості; ліс генерує комплекс соціально-екологічних благ, що потрібно враховувати при оцінці ефективності екологічних проектів певної спрямованості; формування лісових ділянок, в багатьох випадках, потребує не повний ланцюг операцій від підготовки ділянки до набуття деревами певного віку, а тільки доведення існуючих лісових масивів до рівня оптимальної лісистості і оптимальної структури. 


\title{
НАУКОВЕ ВИДАННЯ
}

\author{
Матеріали ІІІ Міжнародної науково-практичної конференції \\ «ФОРМУВАННЯ МЕХАНІЗМУ ЗМНЦНННЯ КОНКУРЕНТНИХ \\ ПОЗИЦІЙ НАЦІОНАЛЬНИХ ЕКОНОМІЧНИХ СИСТЕМ У \\ ГЛОБАЛЬНОМУ, РЕГІОНАЛЬНОМУ ТА ЛОКАЛЬНОМУ ВИМІРАХ» \\ (Тернопіль, 5 квітня 2019 р.)
}

\begin{abstract}
Proceedings of the $3^{\text {nd }}$ International Scientific-Practical Conference "FORMATION OF THE MECHANISM OF NATIONAL ECONOMIC SYSTEMS COMPETITIVE POSITIONS STRENGTHENING IN GLOBAL, REGIONAL AND LOCAL DIMENSIONS"
\end{abstract}

(Тернопіль, April 5, 2019)

\begin{abstract}
Матеріали III Міжнародної науково-практичної конференції «Формування механізму зміцнення конкурентних позицій національних економічних систем у глобальному, регіональному та локальному вимірах» (5 квітня 2019 р.) / Тернопільський національний технічний університет імені Івана Пулюя. - Тернопіль: ФОП Паляниця В. А., 2019. - 168 с.
\end{abstract}

ISBN 978-617-7331-79-6

Відповідальність за зміст і достовірність публікацій несуть автори.

Підписано до друку 23.04.2019. Формат 60×90, 1/16.

Друк лазерний. Папір офсетний. Гарнітура TimesNewRoman.

Умовно-друк. арк. 12,5. Наклад - 100 прим. Замовлення № 230419

$* * * * *$

Друк ФОП Паляниця В. А.

Свідоцтво ДК №4870 від 20.03.2015 р.

м. Тернопіль, вул. Б. Хмельницького, 9а, оф.38. тел. (0352) 528-777. 